Sun, Z., Jian, Z., Stock, J.M., Larsen, H.C., Klaus, A., Alvarez Zarikian, C.A., and the Expedition $367 / 368$ Scientists

Proceedings of the International Ocean Discovery Program Volume 367/368

publications.iodp.org

https://doi.org/10.14379/iodp.proc.367368.105.2018

\section{Site U1501}

Hans Christian Larsen, Zhimin Jian, Carlos A. Alvarez Zarikian, Zhen Sun, Joann M. Stock, Adam Klaus, Jacopo Boaga, Stephen A. Bowden, Anne Briais, Yifeng Chen, Deniz Cukur, Kelsie A. Dadd, Weiwei Ding, Michael J. Dorais, Eric C. Ferré, Fabricio Ferreira, Akira Furusawa, Aaron J. Gewecke, Jessica L. Hinojosa, Tobias W. Höfig, Kan-Hsi Hsiung, Baoqi Huang, Enqing Huang, Xiao-Long Huang, Shijun Jiang, Haiyan Jin, Benjamin G. Johnson, Robert M. Kurzawski, Chao Lei, Baohua Li, Li Li, Yanping Li, Jian Lin, Chang Liu, Chuanlian Liu, Zhifei Liu, Antonio Luna, Claudia Lupi, Anders J. McCarthy, Geoffroy Mohn, Lachit Singh Ningthoujam, Michael Nirrengarten,

Nobuaki Osono, David W. Peate, Patricia Persaud, Ning Qiu,

Caroline M. Robinson, Sara Satolli, Isabel Sauermilch, Julie C. Schindlbeck, Steven M. Skinner, Susanne M. Straub, Xiang Su, Liyan Tian, Froukje M. van der Zwan, Shiming Wan, Huaichun Wu, Rong Xiang, Rajeev Yadav, Liang Yi, Cuimei Zhang, Jinchang Zhang, Yang Zhang, Ning Zhao, Guangfa Zhong, and Lifeng Zhong ${ }^{2}$

Keywords: International Ocean Discovery Program, IODP, JOIDES Resolution, Expedition 367, Expedition 368, Site U1501, northern South China Sea, continent-ocean transition zone, outer margin high, hyperextension, continental breakup, thinning, rifting, basement, Cenozoic, Mesozoic, prerift, land facies, Eocene marine deposition, subsidence

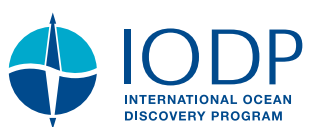

\section{Contents}

1 Site summary

6 Background and objectives

7 Operations

11 Lithostratigraphy

24 Structural geology

26 Biostratigraphy

33 Paleomagnetism

41 Geochemistry

49 Physical properties

53 Downhole measurements

56 Correlation to seismic data

61 References

\section{Site summary Background and objectives}

Site U1501 (proposed Site SCSII-41A; $18^{\circ} 53.0923^{\prime} \mathrm{N}$, $115^{\circ} 45.9455^{\prime}$ E) (Sun et al., 2016) within the South China Sea (SCS) northern margin (Figure F1) is located on a broad regional basement high (outer margin high $[\mathrm{OMH}]$ ). The $\mathrm{OMH}$ is the most landward of four distinct highs within the continent-ocean transition (COT) and is followed seaward by Ridges A, B, and C (Figures F2, F3, F4). Site U1501 is located at $2845.8 \mathrm{~m}$ below sea level (mbsl). Small rift basins of presumed Paleogene age are located on top of the $\mathrm{OMH}$ (Figure F2). These basins can be traced landward into much deeper half-graben basins that formed during the main phase of crustal extension. The rift basins located on the $\mathrm{OMH}$, therefore, offer options to recover the stratigraphy of these basins by drilling to moderate depths, testing existing stratigraphic interpretations, and extrapolating the findings margin wide. Recovering and characterizing these sequences were key objectives at Site U1501, and the specific goal was to constrain the timing and duration of crustal extension, the tectonic vertical movements during rifting, and the subsequent postrift thermal subsidence. The crystalline basement at Site U1501 is most likely located far below the acoustic basement at $\approx 600 \mathrm{~m}$ and was not an objective for this site.

At $2846 \mathrm{mbsl}$, Site U1501 is one of the few Ocean Drilling Program (ODP) and Integrated Ocean Drilling Program sites in the SCS above the modern carbonate compensation depth (CCD) of the SCS. Sites U1504 and U1505, also at the OMH, are situated at $<3000$ $\mathrm{mbsl}$. The younger stratigraphy is therefore also the focus of some secondary scientific objectives related to Neogene environmental development of the SCS and adjacent landmasses of Southeast Asia. Among these secondary objectives are to (1) reconstruct the history of the east Asian monsoon evolution and of deepwater exchanges between the SCS and Pacific Ocean and (2) explore the sedimentary responses to the Cenozoic regional tectonic and environmental development of the Southeast Asia margin.

\footnotetext{
${ }^{1}$ Larsen, H.C., Jian, Z., Alvarez Zarikian, C.A., Sun, Z., Stock, J.M., Klaus, A., Boaga, J., Bowden, S.A., Briais, A., Chen, Y., Cukur, D., Dadd, K.A., Ding, W., Dorais, M.J., Ferré, E.C., Ferreira, F., Furusawa, A., Gewecke, A.J., Hinojosa, J.L., Höfig, T.W., Hsiung, K.-H., Huang, B., Huang, E., Huang, X.-L., Jiang, S., Jin, H., Johnson, B.G., Kurzawski, R.M., Lei, C., Li, B., Li, L., Li, Y., Lin, J., Liu, C., Liu, C., Liu, Z., Luna, A., Lupi, C., McCarthy, A.J., Mohn, G., Ningthoujam, L.S., Nirrengarten, M., Osono, N., Peate, D.W., Persaud, P., Qui, N., Robinson, C.M., Satolli, S., Sauermilch, I., Schindlbeck, J.C., Skinner, S.M., Straub, S.M., Su, X., Tian, L., van der Zwan, F.M., Wan, S., Wu, H., Xiang, R., Yadav, R., Yi, L., Zhang, C., Zhang, J., Zhang, Y., Zhao, N., Zhong, G., and Zhong, L., 2018. Site U1501. In Sun, Z., Jian, Z., Stock, J.M., Larsen, H.C., Klaus, A., Alvarez Zarikian, C.A., and the Expedition $367 / 368$ Scientists, South China Sea Rifted Margin. Proceedings of the International Ocean Discovery Program, 367/368: College Station, TX (International Ocean Discovery Program). https://doi.org/10.14379/iodp.proc.367368.105.2018 2 Expedition 367/368 Scientists' addresses.

MS 367368-105: Published 28 September 2018

This work is distributed under the Creative Commons Attribution 4.0 International (CC BY 4.0) license. (cc))BY
} 
Figure F1. Bathymetric maps showing Expedition 367/368 sites (stars), and (A) regional and (B) local coverage of multichannel seismic reflection data and OBS data. Thick blue and red lines are key seismic lines used for planning of the drilling transect. A. Magnetic isochrons (orange lines) from Briais et al. (1993). B. Magnetic picks (orange squares) from the same reference, extracted from the Seton et al. (2014) compilation. Chron labels for the picks correspond to the old edge of the normal polarity intervals (see Ogg et al. [2016] timescale for ages). Orange square = Leg 184 Site 1148, yellow squares $=$ Expedition 349 Sites U1432 and U1435.

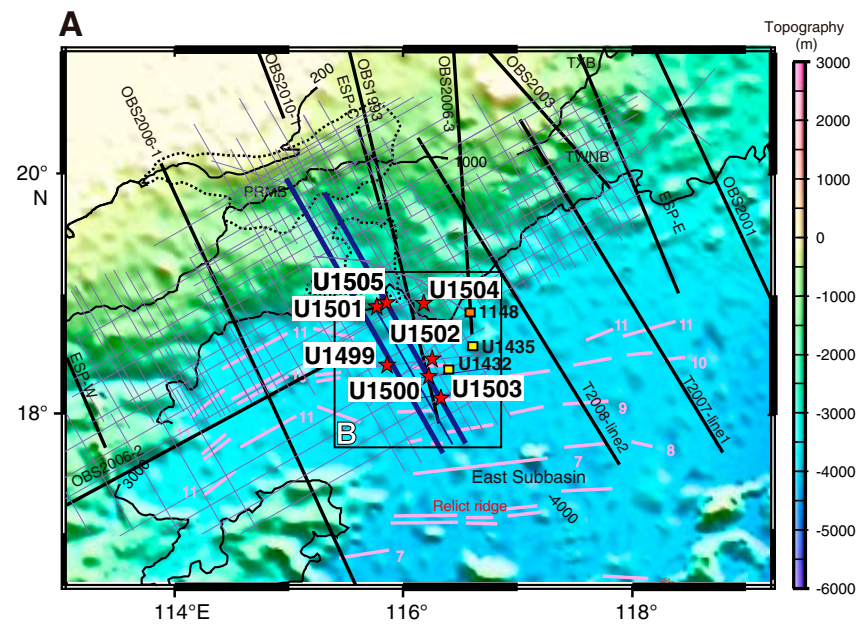

B

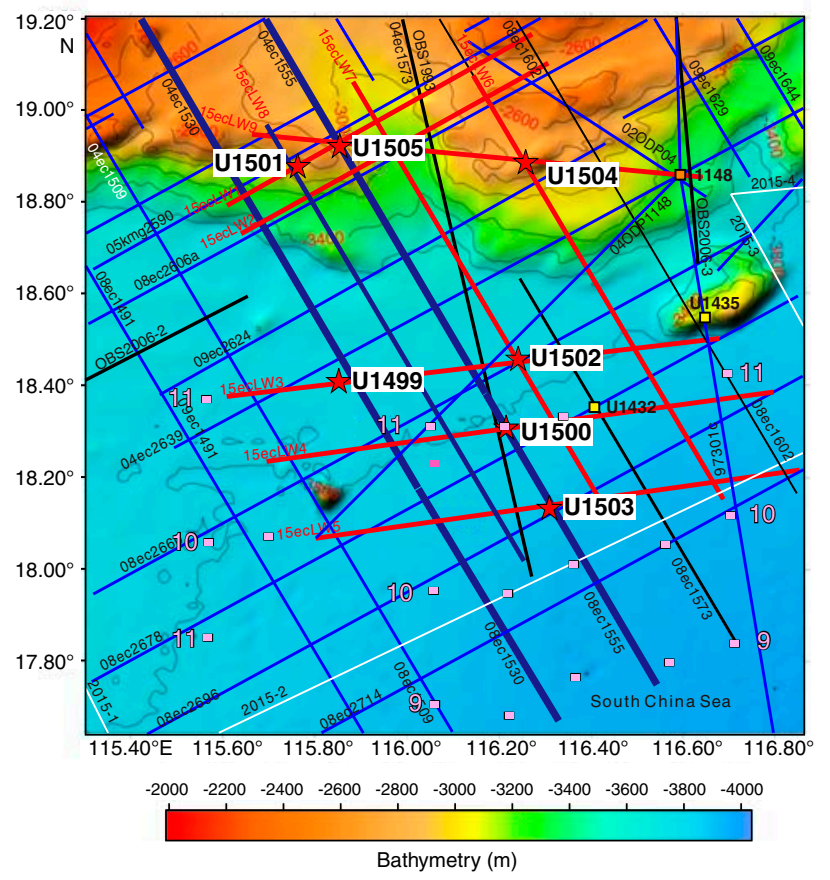

\section{Operations}

We conducted operations in four holes at Site U1501. In Holes U1501A and U1501B, Core $1 \mathrm{H}$ missed the sediment-water interface and retrieved full core barrels, indicating that the core was shot from below the seafloor. Hole U1501C $\left(18^{\circ} 53.0919^{\prime} \mathrm{N}\right.$, $\left.115^{\circ} 45.9485^{\prime} \mathrm{E} ; 2846 \mathrm{mbsl}\right)$ was cored with the advanced piston corer (APC) system from the seafloor to $461.8 \mathrm{~m}$ and recovered $447.8 \mathrm{~m}$ (96.3\%). Hole U1501D ( $18^{\circ} 53.0929^{\prime} \mathrm{N}, 115^{\circ} 45.9370^{\prime} \mathrm{E} ; 2846$ $\mathrm{mbsl}$ ) was drilled without coring from the seafloor to $433.5 \mathrm{~m}$ and then cored with the rotary core barrel (RCB) system to $644.3 \mathrm{~m}$. A total of $78.8 \mathrm{~m}$ of core was recovered (37.4\%). Hole U1501D was logged with the triple combo tool string from 113 to $299.3 \mathrm{~m}$.

\section{Lithostratigraphy}

The sedimentary succession recovered at Site U1501 is composed of clay-rich nannofossil ooze, silty clay, clayey silt, sand, siltstone, sandstone with minor conglomerate, and rare volcanic ash. The succession is divided into three major lithostratigraphic units (I, II, and III) distinguished on the basis of sediment composition, particularly the relative abundance of the calcareous and siliciclastic fractions (Figure F30).

Lithostratigraphic Unit I is a 303 m thick, Holocene-upper Oligocene succession dominated by clay-rich nannofossil ooze and nannofossil ooze with clay, with minor amounts of nannofossil-rich foraminifer sand or silty sand. A felsic volcanic ash layer occurs in Section 368-U1501A-1H-7, and an ash pod was observed in Section 368-U1501C-3H-1. Unit I is divided into the following subunits:

- Subunit IA (0-25.47 m),

- Subunit IB (25.47-66.17 m),

- Subunit IC (66.30-156.70 m),

- Subunit ID (156.80-191.99 m),

- Subunit IE (191.99-293.09 m), and

- Subunit IF (293.90-303.01 m).

These divisions are based on changes in lithology, particularly the clay to nannofossil ratio, the presence and abundance of foraminifers, and/or physical properties. The lower contact of Unit I is erosional and marked by the emplacement of a poorly sorted sandy layer. At the boundary, marked changes in $P$-wave velocity, natural gamma radiation (NGR), magnetic susceptibility, porosity, moisture and density (MAD), color, carbonate content, and biostratigraphy indicate a small hiatus (Figure F30). Unit I was deposited in a deepmarine environment, and lithologic changes between subunits likely reflect the amount of terrigenous input into a relatively open ocean setting. This input may be delivered as buoyant sediment plumes from shallower shelf environments and rarely by weak (distal) turbidity currents. Soft-sediment deformation in Subunit IB indicates slumping downslope of parts of the sequence.

Lithostratigraphic Unit II is $296 \mathrm{~m}$ thick and late Oligocene to late Eocene in age. The unit consists of variable amounts of clay, silt, and sand with minor nannofossil-rich clay, nannofossil ooze, and silt with organic matter. Gravel-sized grains occur, including shell fragments and glauconite, as well as carbonate and pyrite concretions. Unit II is divided into six subunits:

- Subunit IIA (303.01-385.26 m),

- Subunit IIB (388.80-452.69 m),

- Subunit IIC (452.60-482.33 m),

- Subunit IID (491.00-519.80 m),

- Subunit IIE (529.30-548.64 m), and

- Subunit IIF (548.64-598.91 m).

The uppermost two subunits define a fining-upward succession of glauconite-sand dominated to siltstone and clay overlain by clay with nannofossils. Subunits IIC and IE are dominated by sandstone with calcite; Subunit IID has more fine-grained, organic-rich lithologies; and Subunit IIF is similar to Subunit IIB but has more coarse-grained sediment and distinctive weak red and reddish gray intervals within the green glauconite-bearing sands. Coarse sandto pebble-sized shell fragments are common in Unit II, and coral fragments were occasionally observed in the upper part of the unit. 


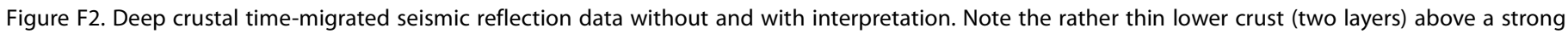

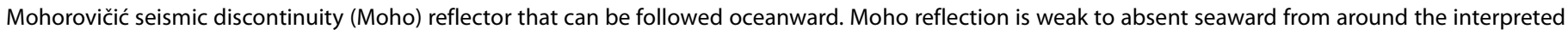

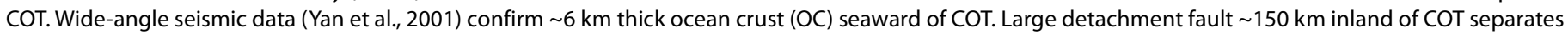

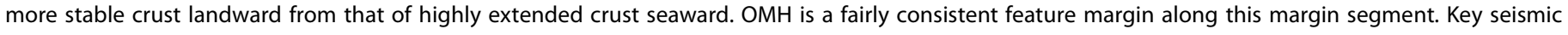

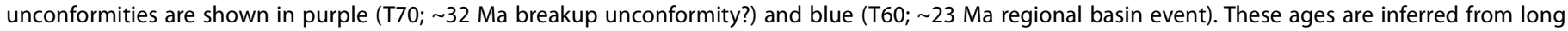

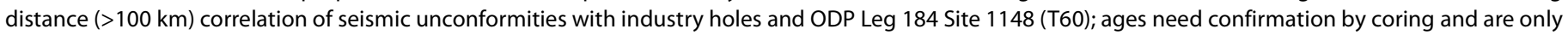

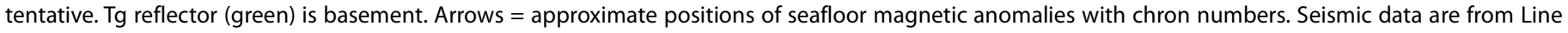

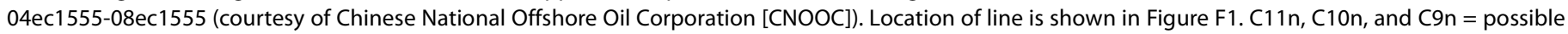
chrons. MSB = midslope basin.
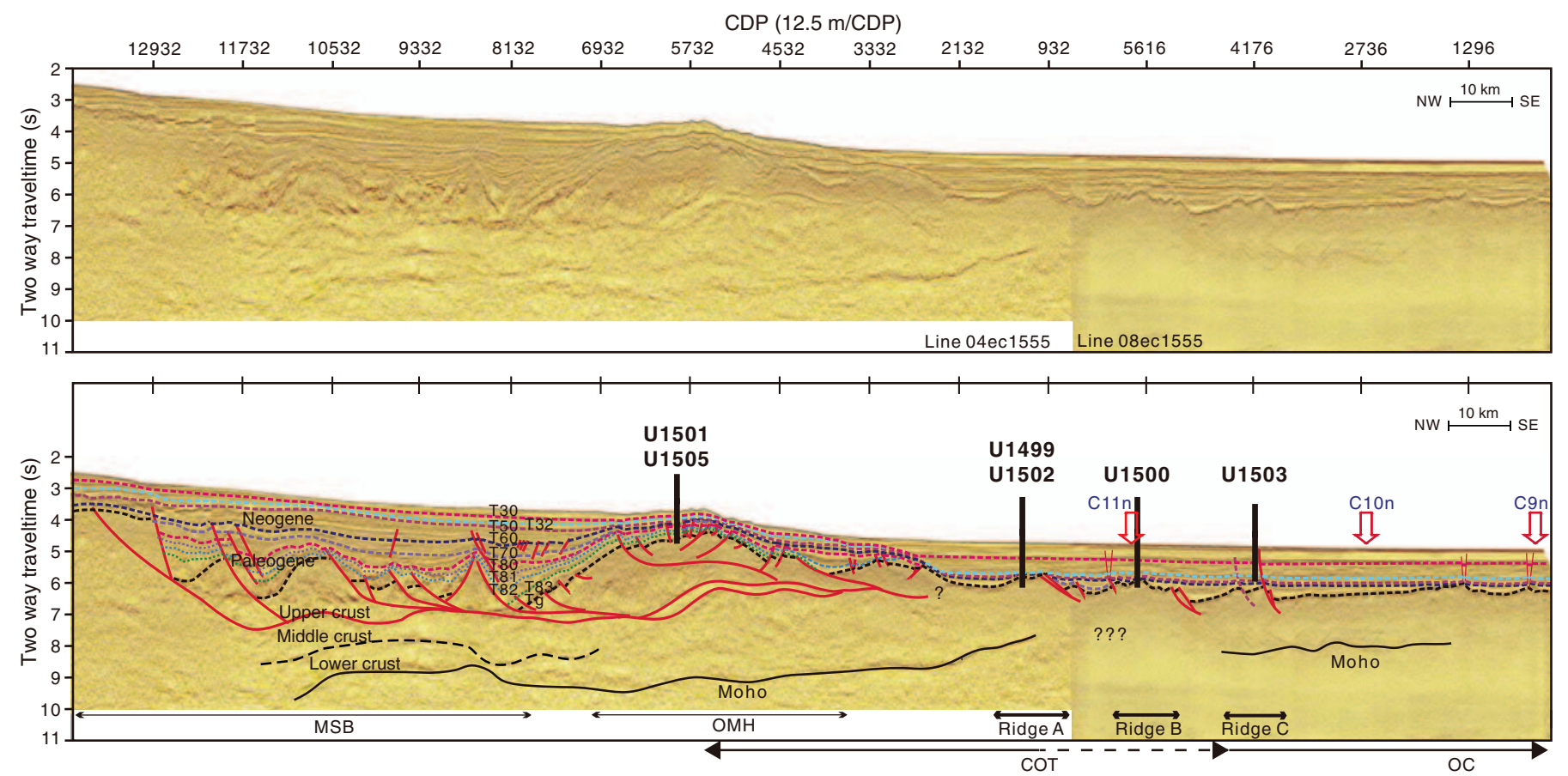

Glauconite and quartz minerals dominate the siliciclastic grain component. Diagenetic pyrite is common. Unit II most likely represents a gradual change upward from shallow-water (outer shelf or upper continental slope) to deepwater (lower slope) depositional environments. The Unit II/III boundary was not recovered but is marked by an abrupt change in magnetic susceptibility, NGR, and $P$-wave velocity. A change in the apparent dip of strata from near horizontal in Unit II to $\sim 20^{\circ}$ in Unit III suggests that the contact is unconformable.

Lithostratigraphic Unit III (598.91 $\mathrm{m}$ to the bottom of the hole) is well lithified and composed of poorly sorted, feldspar-rich sandstone interbedded with moderately to well-sorted, medium- to finegrained sandstone and, rarely, siltstone and poorly sorted conglomerate. The age is unknown because no fossils were recognized. Unit III is divided into two subunits: IIIA (598.91-629.79 m) and IIIB (629.79-643.56 m). Subunit IIIA is composed of coarse-grained heterolithic sandstone, sandstone with calcite clasts, and minor conglomerate and siltstone. Pebble- to cobble-sized clasts include felsic intrusive and volcanic rocks, sedimentary rocks, metamorphic rocks, and rare gabbro. Subunit IIIB consists of sandstone and minor sandstone with organic matter. Subunit IIIB is finer grained than Subunit IIIA and has finely laminated intervals. We speculate that Unit III was formed in continental to littoral environments with a provenance not far from the site.

\section{Structural geology}

Unit I shows predominantly horizontal to subhorizontal bedding with local soft-sediment deformation structures such as slump folds. Unit I is devoid of any structures related to tectonic deformation, apart from some rare normal faults with minor offsets.

Unit II is characterized by subhorizontal to gently dipping bedding. Steep dips up to $40^{\circ}$ are locally observed in close relation to parallel lamination and are therefore interpreted as cross-laminae. In contrast to Unit I, deformation structures were observed within Unit II, although their occurrence is rather heterogeneously distributed. Planar to irregular millimeter-scale normal faults and joints were observed in Subunit IIA, typically with offsets ranging from 0.1 to $0.5 \mathrm{~cm}$ and apparent dips of $10^{\circ}-40^{\circ}$. Striations and slickensides were documented locally where the surfaces of such structures are exposed. Deformation in the underlying Subunits IIC-IIF is essentially characterized by randomly distributed occurrence of single to branched uniform calcite and quartz veins. Recognition of deformational structures was difficult due to drilling disturbance throughout this unit.

The acoustic basement marks the top of Unit III. This unit shows a weak tilting of stratified beds expressed in apparent dips on split core surfaces up to $\sim 20^{\circ}$. Again, deformation structures remain scarce and heterogeneously distributed in Unit III. The recognized 
Figure F3. Two-way traveltime to (A) basement (Tg reflector) and (B) T60 unconformity. Proposed drilling transect (thick black line) is approximately at the center of a margin segment bounded to the southwest by a transform fault. Northeastern boundary of margin segment around Site U1435. At this location, $\mathrm{OMH}$ and Ridge $A$ seem to coalesce, and Ridges $\mathrm{B}$ and $\mathrm{C}$ in COT become indistinct toward the northeast within the next margin segment. Note that $\mathrm{OMH}$ is slightly oblique to more parallel Ridges $\mathrm{A}, \mathrm{B}$, and $\mathrm{C}$.
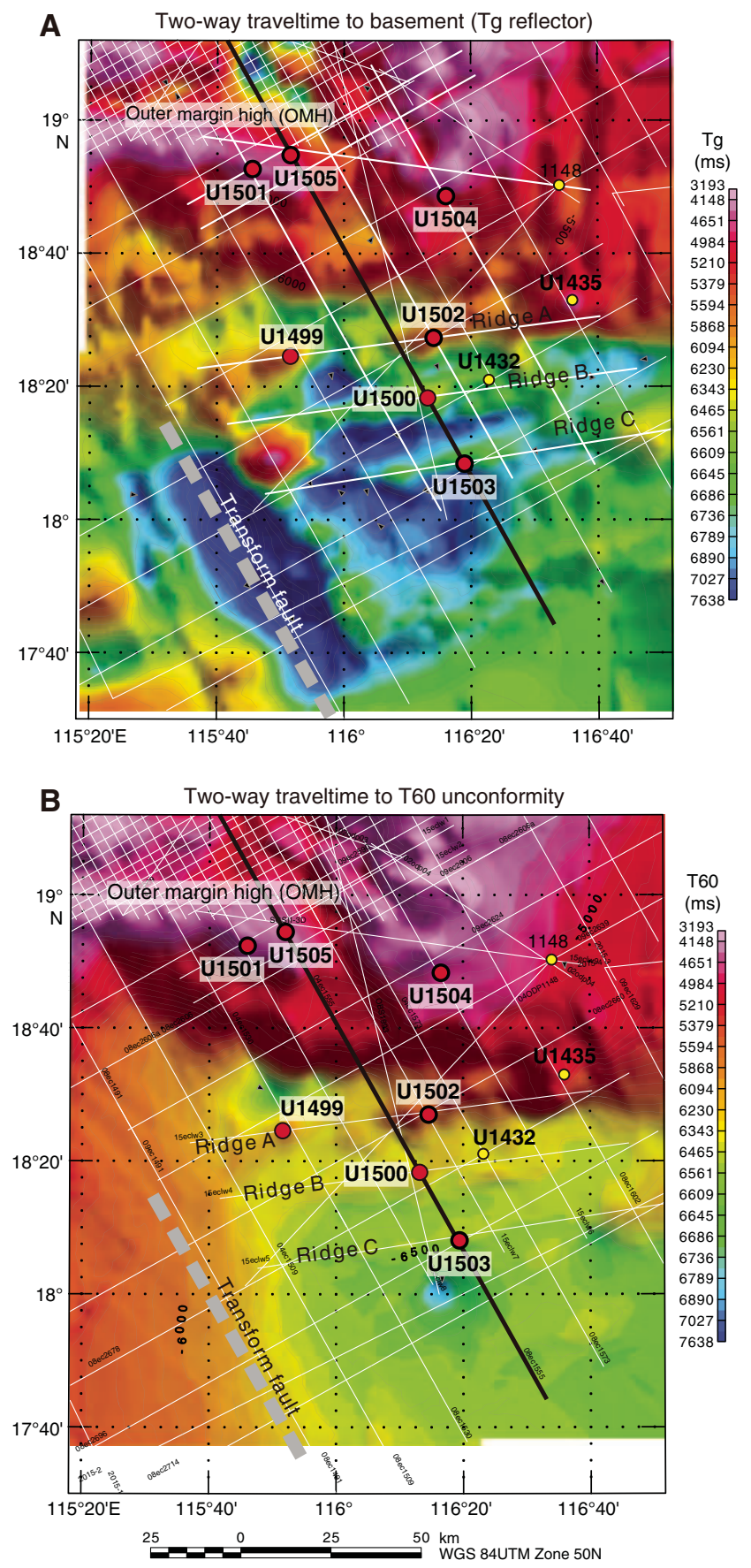

structures consist of veins, fractures, and local microfaults associated with cataclastic fault gouge.

In conclusion, despite the various tilting of reflectors $\left(\sim 5^{\circ}\right)$ and the proximity of extensional structures observed on seismic profiles, only weak evidence of bedding tilting and/or deformation
Figure F4. Bathymetry with seismic lines, Site U1501. Note that site is not at the exact crossing of seismic Lines 15ecLW8 and 15ecLW1.

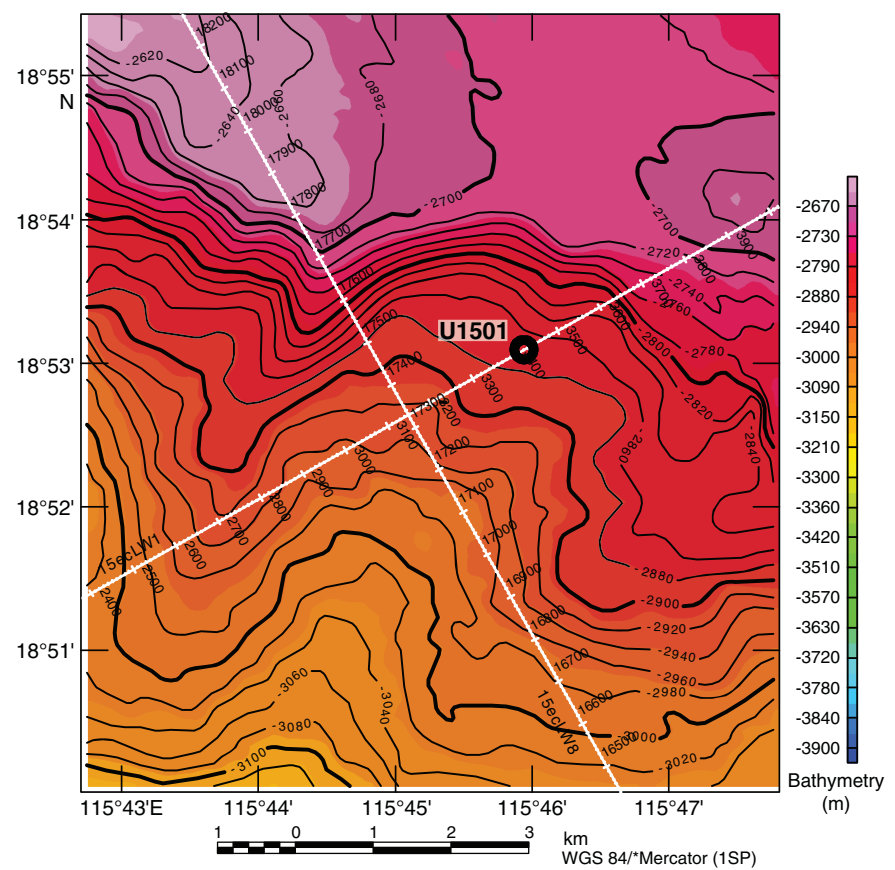

structures was observed at this site, possibly due to the nature of the sediments.

\section{Biostratigraphy}

All core catcher samples at Site U1501 were analyzed for calcareous nannofossils, diatoms, and foraminifers, with select core catchers examined for ostracods. Additional samples were taken from the split working-half sections when necessary to refine the ages between core catcher samples. Preservation of calcareous microfossils varies from good in Unit I (Cores 368-U1501A-1H, $368-\mathrm{U} 1501 \mathrm{~B}-1 \mathrm{H}$, and $368-\mathrm{U} 1501 \mathrm{C}-1 \mathrm{H}$ through $44 \mathrm{X})$ to poor in Units II and III (Cores 368-U1501C-45X through 62X and 368U1501D-2R through 5R). Planktonic foraminifers and calcareous nannofossils are abundant in Unit I, common to rare in Unit II and upper Unit III, and barren in the rest of Unit III (Cores 368U1501D-6R though 27R). Diatoms are few with moderate preservation in Samples 368-U1501A-1H-CC, 368-U1501B-1H-CC, and $368-\mathrm{U} 1501 \mathrm{C}-1 \mathrm{H}-\mathrm{CC}$ and $2 \mathrm{H}-\mathrm{CC}$. The rest of the core catcher samples are barren of diatoms with the exception of Samples 368U1501C-3H-CC, 4H-CC, 33F-CC through 35F-CC, and 46X-CC, in which diatoms are rare with poor preservation. Diatoms are common in burrows found in interval 368-U1501C-35F-1, 118-119 cm, with poor preservation.

Forty biostratigraphic datums were identified in a mostly continuous succession from the Eocene to Holocene, which indicates that Holes U1501C and U1501D penetrated late Eocene or older strata (Figure F30). The Pleistocene/Pliocene boundary ( 2.6 Ma) was placed within Core 368-U1501C-7H, the Pliocene/Miocene boundary $(\sim 5.3 \mathrm{Ma})$ within Core $9 \mathrm{H}$, the Miocene/Oligocene boundary ( 23.0 Ma) between Cores 41X and 42X, and the Oligocene/Eocene boundary ( 33.9 Ma) between Cores 53X and 54X. Sedimentation rates vary from $\sim 13 \mathrm{~mm} / \mathrm{ky}$ in the early Oligocene, $\sim 11 \mathrm{~mm} / \mathrm{ky}$ in the Miocene, and $\sim 14 \mathrm{~mm} / \mathrm{ky}$ in the Pliocene to 24 $\mathrm{mm} / \mathrm{ky}$ in the Pleistocene. Low sediment accumulation rates $(\sim 3.6$ 
$\mathrm{mm} / \mathrm{ky}$ ) during the late Eocene through the early Oligocene and in the late Miocene suggest the presence of hiatuses in the sedimentary record during these periods. In contrast, higher sediment accumulation rates $(35 \mathrm{~mm} / \mathrm{ky})$ exist during the late Oligocene and the early Miocene.

Predominance of shallow-water benthic foraminifer and ostracod assemblages in Cores 368-U1501C-45X through 62X and 368-U1501D-2R through 6R indicate an upper bathyal to continental shelf paleoenvironment during the Eocene to the early Oligocene. Predominantly abyssal benthic foraminifers and ostracods above Core 368-U1501C-44X indicate that deepwater conditions existed in this part of the SCS since the early Oligocene.

\section{Paleomagnetism}

Paleomagnetic investigations combined measurement and inline alternating field (AF) demagnetization of archive-half sections on the $2 \mathrm{G}$ Enterprises superconducting rock magnetometer (SRM) with the measurement of discrete samples either AF or thermally demagnetized.

The rock magnetic experiments on six representative samples from Hole U1501C show saturation remanent magnetization $(\mathrm{SIRM}) / \mathrm{X}$ ratios between 12.8 and $14.6 \mathrm{kA} / \mathrm{m}$, indicating the predominance of greigite in Unit I of Hole U1501C, also documented by scanning electron microscopy (SEM) in $2-10 \mu \mathrm{m}$ grains. Thermal demagnetization behaviors show that greigite dominates the natural remanent magnetization (NRM), at least downhole to $83 \mathrm{~m}$. However, the magnetic remanence left above $575^{\circ} \mathrm{C}$ suggests contributions from additional phases such as maghemite (Curie temperature $\left.\left[T_{\mathrm{C}}\right]=\sim 590^{\circ}-675^{\circ} \mathrm{C}\right)$ or hematite $\left(T_{\mathrm{C}}=\sim 675^{\circ} \mathrm{C}\right)$.

Both AF and thermal treatments on discrete samples successfully removed the steep low-temperature/coercivity component that represents the drilling overprint. The mean inclination gathered from the high-temperature component is $37.3^{\circ} \pm 6.6^{\circ}$, corresponding to a paleolatitude of $20.8^{\circ} \pm 3.3^{\circ}$ for Unit I (see Lithostratigraphy). Many of the AF-demagnetized discrete samples reveal trends of reversed or normal polarity in the last step of demagnetization $(50 \mathrm{mT})$ and are more difficult to interpret.

The magnetostratigraphy in Holes U1501C and U1501D is based on directions derived from the raw moments measured by the SRM after $25 \mathrm{mT}$ demagnetization step and from the corroborative evidence from discrete samples. Magnetostratigraphy was correlated to the standard timescale and plotted along with the tie points from the microfossil ages from shipboard paleontologists. The paleomagnetic and paleontological age constraints match well over most of the section (Figure F30). A succession of eight normal and five reversed events was recognized in Hole U1501D. However, the lack of biostratigraphic constraints throughout Hole U1501D prevented even a tentative correlation of these events with the standard timescale.

\section{Geochemistry}

Interstitial water samples were obtained downcore to $450 \mathrm{~m}$ (Subunit IIB). Within Unit I, variations are mainly the result of diagenetic and microbial processes, and measurements of alkalinity, phosphate, ammonia, and sulfate are within the typical ranges for the region (3.5-5 mM alkalinity, $250-510 \mu \mathrm{M}$ phosphate, $<30 \mu \mathrm{M}$ ammonia, and $<26 \mu \mathrm{M}$ sulfate). However, more atypically (particularly when compared to Expedition 367 Site U1499), the main changes associated with microbial processes are notable only within the uppermost $25 \mathrm{~m}$ in Subunit IA and are typical of organic matter degradation. Deeper than $25 \mathrm{~m}$ within Unit I, changes in interstitial water chemistry appear inhibited until $300 \mathrm{~m}$. These changes may be a consequence of the low organic carbon concentration and high carbonate content ( $\sim 50 \mathrm{wt} \%)$ of Unit I. Decreases in sulfate concentrations with depth are more pronounced in Unit II $(>300 \mathrm{~m})$, and within this zone there is heavy pyritization and total sulfur (TS) contents are high, suggesting sulfate reduction has taken place. Within the uppermost part of Unit II (300-370 m), chloride, bromide, and sodium are notably lower (chloride $=500 \mathrm{mM}$, cf. 565 $\mathrm{mM}$; bromide $=0.75 \mathrm{mM}$, cf. $0.9 \mathrm{mM}$; and sodium $=410 \mathrm{mM}$, cf. $480 \mathrm{mM}$ ). This difference in interstitial water chemical composition is sharp and could result from pressure-isolated units retaining a distinct formation water chemistry or from the migration of chloride-poor formation water.

Headspace gas concentrations are below background laboratory levels in all samples collected from Site U1501 ( $<1 \%$ ppmv). Total organic carbon (TOC) content is typically $<0.5 \mathrm{wt} \%$ in Unit I, except from 0 to $50 \mathrm{~m}$ (Subunit IA). Within this interval, a typical black marine mud has a TOC of $\sim 1 \mathrm{wt} \%$. TOC was also typically $<0.5 \mathrm{wt} \%$ in Units II and III, except for a few carbonaceous lithologies: sandstones with plant phytoclasts associated with an ash-rich boghead coal in Unit II (interval 368-U1501D-9R-1, 10-15 cm) and a bitumen-impregnated sandstone in Unit III (interval 27R-1, 12-16 cm). TS content is low in Unit I: $\sim 1 \mathrm{wt} \%$ in Subunit IA and below effective shipboard detection limits of $0.01 \mathrm{wt} \%$ for the rest of Unit I. TS content is higher in Unit II; >1 wt\% in the muddier uppermost part of Unit II and an average of $0.5 \mathrm{wt} \%$ in the sandier, deeper part.

Elemental compositions primarily reflect geological units and changes in lithology. Within Unit I, carbonate contents are high and exceed $50 \mathrm{wt} \%$ within foraminifer-rich intervals (compositionally a limestone). Within Units II and III, carbonate is less common, and the units are predominantly siliciclastic with a distinction between units that are mud rich and feldspathic and sandier units toward the base of the hole. Calcium and strontium are associated with biogenic sediments in Unit I, but in deeper units they covary with aluminum. Within the base of Units II and III, sodium and potassium are both high, which is consistent with the dominant presence of feldspathic sediments. The higher aluminum proportion within the uppermost part of Unit II is consistent with the muddier, clay-rich lithologies present here.

\section{Physical properties}

Hole U150A is divided into four units based on the sediment and rock physical properties. Physical properties (PP) Unit 1 (0-300 $\mathrm{m})$ experienced the most evident changes in sediment compaction, which is expressed by increasing bulk density (from 1.4 to 2.0 $\mathrm{g} / \mathrm{cm}^{3}$ ) and $P$-wave velocities (from 1450 to $1930 \mathrm{~m} / \mathrm{s}$ ) and decreasing porosity (from $85 \%$ to $45 \%$ ) with depth. Because PP Unit 1 consists mostly of calcareous ooze, it has relatively low NGR (between 20 and 40 counts/s) and magnetic susceptibility (between $10^{-6}$ and $\left.10^{-5} \mathrm{SI}\right)$. The onset of PP Unit $2(300-450 \mathrm{~m})$ is marked by a rapid increase in NGR and porosity values and a rapid decrease in bulk densities and $P$-wave velocities, corresponding to a shift to a different lithologic unit with sand, silt, and clay-enriched sediments. Within the entire unit, NGR is persistently high (60-80 counts/s), whereas magnetic susceptibility remains as low as $10 \times 10^{-5} \mathrm{SI}$. $P$ wave velocities and bulk densities continue to increase with core depth. Most physical properties of PP Unit 3 (450-600 m) have similar values to those of Unit 2, except that $P$-wave velocities are extremely high, up to $4000-6000 \mathrm{~m} / \mathrm{s}$ at some interbeds, and bulk densities and porosities increase and decrease to $2.6 \mathrm{~g} / \mathrm{cm}^{3}$ and $2 \%-$ $3 \%$, respectively, at parallel depths. PP Unit $4(600-657 \mathrm{~m})$ is dis- 
tinct from other units due to higher mean values of NGR (80 counts/s), bulk density $\left(2.6 \mathrm{~g} / \mathrm{cm}^{3}\right)$, magnetic susceptibility $(500 \times$ $\left.10^{-5} \mathrm{SI}\right)$, and $P$-wave velocity $(4500 \mathrm{~m} / \mathrm{s})$. Throughout the hole $(0-$ $657 \mathrm{~m})$, thermal conductivities increase from 0.7 to $3.4 \mathrm{~W} /(\mathrm{m} \cdot \mathrm{K})$, most likely as a result of increasing sediment compaction and changes in sediment compositions. L* reflectance values are highly relevant to weight percent carbonate in sediments, which exhibit relatively high $\mathrm{L}^{*}$ values between 100 and 160 in the upper $300 \mathrm{~m}$ and thereafter remain as low as 90 .

\section{Downhole measurements}

Wireline logging was conducted in Hole U1501D using a modified triple combo tool string that included the Hostile Environment Natural Gamma Ray Sonde (HNGS), Hostile Environment LithoDensity Sonde (HLDS), High-Resolution Laterolog Array (HRLA), and magnetic susceptibility sonde (MSS). The triple combo run collected good data between $115.1 \mathrm{~m}$ (base of the drill pipe) and $300 \mathrm{~m}$, where it encountered an impenetrable obstruction. Four logging units are defined:

- Logging Unit 1 (base of the drill pipe to $190 \mathrm{~m}$ wireline depth below seafloor [WSF]) is characterized by intervals of large hole diameter and relatively high variability in NGR and magnetic susceptibility.

- Logging Unit 2 (190-260 m WSF) is characterized by a relatively constant hole diameter, relatively homogeneous logs, and submeter-scale layering.

- Logging Unit 3 (260-275 m WSF) again shows a relatively large hole diameter, as well high variability in NGR, density, and resistivity logs.

- Logging Unit 4 (275-300 m WSF) exhibits relatively large values of resistivity and magnetic susceptibility.

The upward log pass indicated a collapsed hole at $\sim 156.3 \mathrm{~m}$ drilling depth below seafloor (DSF) on the caliper curve, and for safety reasons no further attempts to descend deeper than that undergauge spot were made. Because the interval of the collapsed hole was located only $\sim 40 \mathrm{~m}$ below the base of the pipe, the originally planned Formation MicroScanner (FMS)-sonic tool string was not run. Four in situ formation temperature measurements were made in Hole U1501C, yielding a geothermal gradient of $81.4^{\circ} \mathrm{C} / \mathrm{km}$ and a calculated heat flow of $100.1 \mathrm{~mW} / \mathrm{m}^{2}$. These values are comparable to the relatively high values observed at some ODP and Integrated Ocean Drilling Program sites in this part of the SCS.

\section{Background and objectives}

Site U1501 is located at $2845.8 \mathrm{mbsl}$ on a broad, regional basement high $(\mathrm{OMH})$ within the SCS northern margin (Figures F2, F4). The OMH features prominently in the two-way traveltime (TWT) depth to basement map and is one of four distinct basement highs found across the COT. The OMH is the most landward of these highs within the COT and is followed seaward by Ridges A, B, and C (Figure F3). The crustal thickness below the $\mathrm{OMH}$ is significantly greater than that of the ridges located more seaward within the COT. Site U1501 is located near the crossing of seismic Lines 15ecLW8 and 15ecLW1 (Figures F5, F6).

Small rift basins are located on top of the OMH (Figure F3). An important feature of these $\mathrm{OMH}$ basins is that they can be traced landward on seismic data into much deeper half-graben basins that formed during the main phase of crustal extension. The sediment fill of these basins shows development from initial rifting and half-
Figure F5. Original and predrilling interpretation of seismic dip Line 15 ecLW1 crossing with seismic Line 15ecLW8 (red tick mark) and CDPs (CDP distance $=6.25 \mathrm{~m}$ ). Seismic stratigraphic Unconformities T20 (2.6 Ma), T30 (5.3 Ma), T32 (10.0 Ma), T40 (16 Ma), T50 (19.1 Ma), T60 (23.0), T80 (38.0 Ma), and T83 (unknown age) and acoustic basement Reflector Tg are shown. The clear but not extensively coherent seismic reflectors below Tg to $\sim 4.7$ s TWT are semiconcordant to highly discordant to $\mathrm{Tg}$ and interpreted as pre-Cenozoic sediments. Origin of deep, quite strong reflectors ( $\sim 5 \mathrm{~s}$ TWT) is not interpreted.
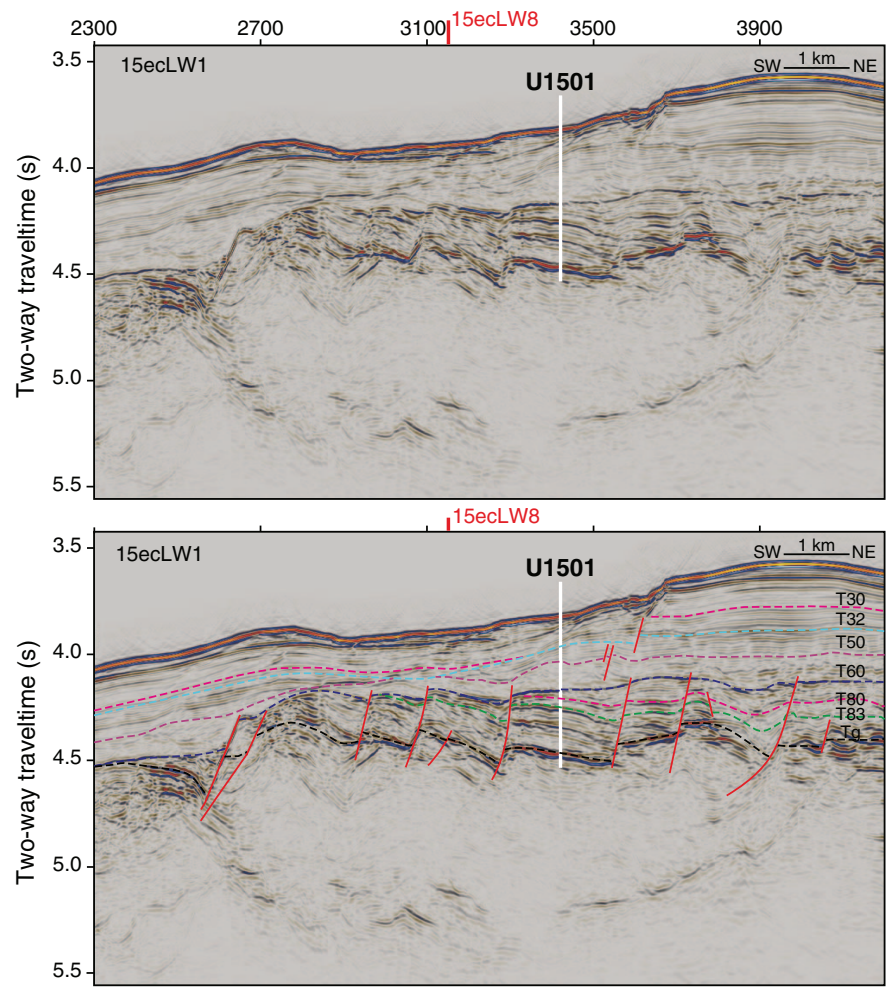

graben fill to subsequent postrift subsidence (Figure F2). The seismic stratigraphy established on industry seismic data (with well control) from the inner margin is extrapolated into these deep fault basins, including those located on the OMH (Figure F5). Therefore, the latter offers options to recover the stratigraphy of these basins by moderately deep drilling, testing existing stratigraphic interpretations, and extrapolating the findings margin wide. The key objective of Site U1501 is to sample the stratigraphic record from one of the small rift basins on top of the OMH. Ideally, the sequence targeted by Site U1501 would represent all stages from prerift sediments through synrift to postrift fill. To recover and characterize these sequences are key objectives of Site U1501, with the specific goal of constraining the timing and duration of crustal extension, the tectonic vertical movements during rifting, and the subsequent postrift thermal subsidence. Unlike the basement at Ridges A, B, and $\mathrm{C}$, the nature of the crystalline basement below the $\mathrm{OMH}$ is not an objective at Site U1501 and is most likely located far below the $\mathrm{Tg}$ horizon planned as the deepest target at the site.

The predrilling interpretation of the seismic unconformities (T30 to T83 and Tg; see Correlation to seismic data in the Expedition 367/368 methods chapter [Sun et al., 2018a]) around Site U1501 is shown in Figure F5. There are clear indications of seismic reflectors below the $\mathrm{Tg}$ reflector in this location, so it is not interpreted as crystalline basement. Poorly constrained seismic velocities of these strata (stacking velocities; CNOOC, unpubl. data) 
Figure F6. Original and predrilling interpretation of seismic strike Line 15 ecLW8 crossing with seismic Line 15ecLW1 (red tick mark) and CDPs (CDP distance $=6.25 \mathrm{~m}$ ). See Figure F5 for description of seismic interpretations. Dashed lines $=$ unconformities, red solid lines $=$ faults.
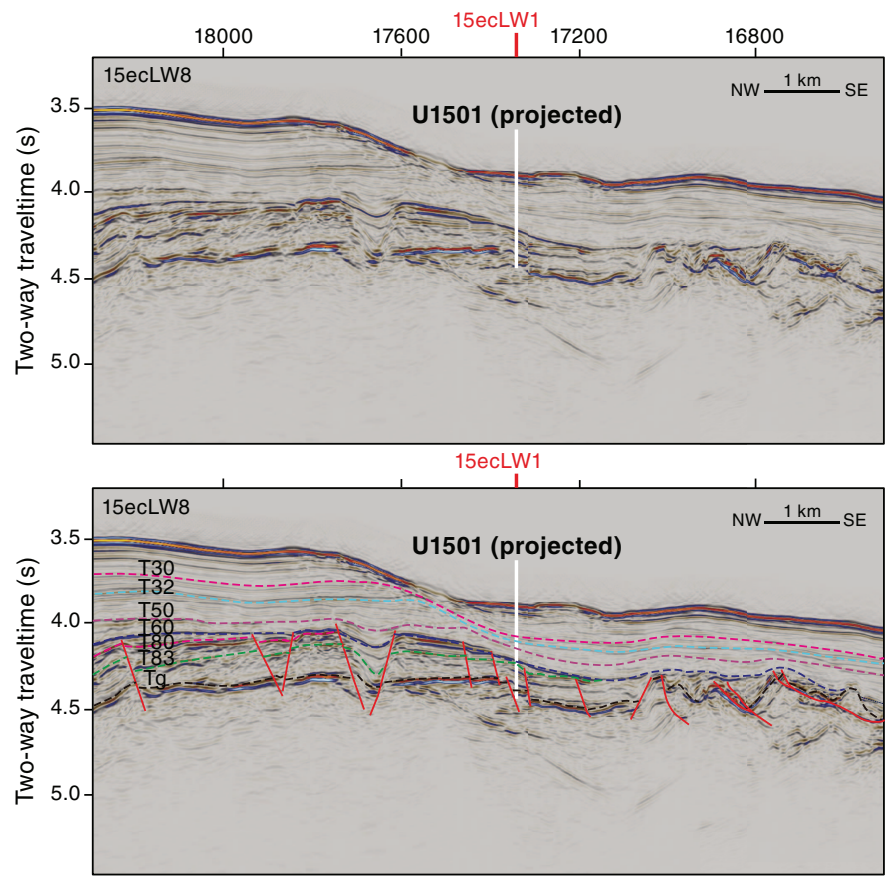

suggest that older sediments could be present. The sub-Tg reflectors seem to be approximately conformal with the overlying package of sediments just around Site U1501. However, further to the southwest of the site around common depth point (CDP) 2800, the seismic data suggest that sub-Tg strata form a tight, synclinal structure truncated by the Tg reflector (Figure F5). The nature and age of the strata represented by these deeper sub-Tg reflectors are completely unknown but are generally considered to be of pre-Cenozoic age in this location.

Site U1501 is located on seismic Line 15ecLW1 at CDP 3421 (Figure F5). This seismic line is interpreted to be close to a true dip line with regard to the tilted faults blocks (tilted northeast) because crossing seismic Line 15ecLW8 (Figure F6) generally shows more horizontal orientation of the strata (i.e., strike line) within the fault blocks. Note, however, that the position of Site U1501 is projected $\sim 1700 \mathrm{~m}$ from the northeast into Line 15ecLW8. This projection in a structurally complex area like the $\mathrm{OMH}$ must therefore be accounted for in any interpretation. Nevertheless, using the velocity structure obtained from drilling for depth conversion, the dip of the post-Tg strata within the fault block drilled at Site U1501 is estimated to be $\sim 5^{\circ}$ toward the northeast and likely to be close to the actual dip. Using the same velocity model (see Physical properties and Correlation to seismic data), the normal faults associated with the block rotation are estimated to dip $55^{\circ}-65^{\circ}$ southwest.

The faults offset the Tg reflector as much as 75 ms TWT (90$120 \mathrm{~m}$ pending seismic velocities). The faults also affect the interpreted T60 unconformity, but in most places these offsets are interpreted to be more like drape structures over a tectonically generated relief with only minor fault offsets, possibly generated by differential compaction. In some places, however, the T60 unconformity can be interpreted as having been significantly faulted (e.g., around CDP 2600 at Line 15ecLW1). Nevertheless, the main faulting is inter- preted to be between the age of the lowermost post-Tg strata and the age of the T60 unconformity. This entire interval is therefore an important objective with regard to the timing and environment of rifting, including vertical crustal movements.

The predrilling interpretation of the seismic stratigraphy of this critical interval shows the T83 (unknown age) and T80 (38.0 Ma) unconformities to be present above the Tg reflector and below the T60 unconformity (23.0 Ma). Sampling this interval will help us determine the environment before the SCS ocean basin formed, possibly including its earliest transgression history. However, the T70 unconformity (33.9 Ma), interpreted to represent final breakup and the approximate start of seafloor spreading, is interpreted (predrilling) to have been eroded away at the OMH by the younger T60 unconformity (Figure F5). However, enough of the rift-to-drift sequence would likely be in place at Site U1501 to meet our objectives, and despite several alternate drill sites that were identified, none held better prospects to recover the T70 unconformity than Site U1501. The basin-wide T60 unconformity is prominently present at Site U1501. The nature of this profound unconformity is an objective together with the post-T60 unconformity stratigraphic interval. This upper interval is expected to provide information on paleowater depth changes within the lower to middle Miocene deposits and thereby constrain the rate of thermal subsidence following initial tectonic subsidence.

The younger stratigraphy is the focus of some secondary scientific objectives related to Neogene environmental development of the SCS and adjacent landmasses of Southeast Asia. Among these objectives are (1) to reconstruct the history of the East Asian monsoon evolution and of deepwater exchanges between the SCS and Pacific Ocean and (2) to explore the sedimentary responses to the Cenozoic regional tectonic and environmental development of the Southeast Asia margin.

The water depth $(2850 \mathrm{~m})$ at Site U1501 makes it one of the few ODP and Integrated Ocean Drilling Program sites within the SCS above the modern CCD. Its hemipelagic deposits, rich in calcareous microfossils, enable the application of stable isotopes and faunal analyses. Key objectives were reconstructions of the monsoonal climate changes of the SCS and surrounding land and upper and deep water variations in the western Pacific Ocean. Particularly, through a comparative study with ODP Leg 184 and IODP Expedition 349 sites, Site U1501, with its sequence of prerift, synrift, and postrift sediments, will greatly help us to understand the sedimentary and paleoenvironmental responses to the tectonic events and the basin evolution experienced by the SCS.

\section{Operations}

We conducted operations in four holes at Site U1501. The original plan included two holes. The first hole was to be cored to $\sim 650$ $\mathrm{m}$ with the APC/extended core barrel (XCB) system, followed by downhole measurements with the triple combo and FMS-sonic tool strings. The second hole was to have a reentry system to $\sim 640 \mathrm{~m}$ followed by coring to $\sim 1063 \mathrm{~m}$ and logging with the triple combo, FMS-sonic, and Versatile Seismic Imager (VSI) tool strings. Actual operations differed significantly from the original plan. Mudlines were missed in Holes U1501A and U1501B, with Core $1 \mathrm{H}$ for each hole retrieving a full core barrel. Hole U1501C $\left(18^{\circ} 53.0919^{\prime} \mathrm{N}\right.$, $115^{\circ} 45.9485^{\prime} \mathrm{E} ; 2845.8 \mathrm{~m}$ water depth) was cored from the seafloor to $461.8 \mathrm{~m}$ and recovered $447.8 \mathrm{~m}$ (96\%). Hole U1501D $\left(18^{\circ} 53.0929^{\prime} \mathrm{N}, 115^{\circ} 45.9370^{\prime} \mathrm{E} ; 2845.8 \mathrm{~m}\right.$ water depth) was drilled without coring from the seafloor to $433.5 \mathrm{~m}$ and cored to $644.3 \mathrm{~m}$, 
recovering $78.8 \mathrm{~m}$ of core (37\%). Coring summaries for Holes U1501A-U1501D are presented in Table T1. We also document our port call activities at the start of the expedition in this section.

\section{Hong Kong port call}

Expedition 368 South China Sea Rifted Margin started at $0754 \mathrm{~h}$ (all times presented are UTC +8 h) on 9 April 2017 with the first line ashore at the China Merchants Wharf in Hong Kong. After the ship cleared immigration and customs, the Expedition 368 Co-
Chief Scientists, IODP staff, and a group of 11 scientists representing each ship laboratory moved onto the ship and started crossover with their Expedition 367 counterparts. Loading and offloading operations began after clearance was issued. Sixty tons of barite were loaded. The rig crew began breaking down 68 stands of $5 \frac{1}{2}$ inch drill pipe and laying them out on the riser hold hatch. All life rafts were offloaded for inspection and returned prior to sailing.

The rest of the Expedition 368 scientists boarded the ship on the morning of 10 April and settled into their rooms. Later that morn-

Table T1. Site U1501 core summary. DRF = drilling depth below rig floor, DSF = drilling depth below seafloor. $\mathrm{NA}=$ not applicable. Core type: $\mathrm{H}=$ advanced piston corer, $\mathrm{F}=$ half-length advanced piston corer, $\mathrm{X}=$ extended core barrel, $\mathrm{R}=$ rotary core barrel, numeric core type $=$ drilled interval. $\mathrm{APCT}-3=$ advanced piston corer temperature tool. (Continued on next two pages.) Download table in CSV format.

\begin{tabular}{|c|c|c|c|c|c|c|c|c|c|c|c|}
\hline \multirow{2}{*}{\multicolumn{5}{|c|}{$\begin{array}{l}\text { Hole U1501A } \\
\text { Latitude: }\end{array}$}} & \multicolumn{6}{|c|}{ Hole U1501B } & \multirow[b]{2}{*}{$18^{\circ} 53.0922^{\prime} \mathrm{N}$} \\
\hline & & & & & \multicolumn{2}{|c|}{$18^{\circ} 53.0922^{\prime} \mathrm{N}$} & \multicolumn{3}{|c|}{ Latitude: } & & \\
\hline \multicolumn{5}{|l|}{ Longitude: } & \multicolumn{2}{|c|}{$115^{\circ} 45.9483^{\prime} \mathrm{E}$} & \multicolumn{3}{|c|}{ Longitude: } & & $115^{\circ} 45.9483^{\prime} \mathrm{E}$ \\
\hline \multicolumn{5}{|c|}{ Seafloor (drill pipe measurement below rig floor, m DRF): } & \multicolumn{2}{|c|}{2857.11} & \multicolumn{4}{|c|}{ Seafloor (drill pipe measurement below rig floor, m DRF): } & 2852.11 \\
\hline \multicolumn{5}{|c|}{ Time on hole (days): } & \multicolumn{2}{|l|}{0.66} & \multicolumn{4}{|c|}{ Time on hole (days): } & 0.05 \\
\hline \multirow{2}{*}{\multicolumn{5}{|c|}{$\begin{array}{l}\text { Total depth (drill pipe measurement from rig floor, } m \text { DRF): } \\
\text { Distance between rig floor and sea level }(m) \text { : }\end{array}$}} & \multicolumn{2}{|l|}{2868} & \multicolumn{4}{|c|}{ Total depth (drill pipe measurement from rig floor, $\mathrm{m}$ DRF): } & 2863 \\
\hline & & & & & \multicolumn{2}{|l|}{10.89} & & stance between rig & loor and se & a level (m): & 10.89 \\
\hline Total penetratic & (drillin & depth be & w seafloor, $\mathrm{m} \mathrm{D}$ & DSF): & 9.5 & & & tal penetration (dril & ing depth $b$ & elow seafloor, m DSF): & 9.5 \\
\hline Total length of & red sec & ion $(m)$ : & & & 9.5 & & & tal length of cored & ection (m): & & 9.5 \\
\hline Total core reco & $\operatorname{red}(\mathrm{m})$ & & & & 9.73 & & & tal core recovered ( & & & 9.83 \\
\hline Core recovery ( & & & & & 102.42 & & & re recovery (\%): & & & 103.47 \\
\hline Drilled interval & & & & & NA & & & illed interval $(\mathrm{m})$ : & & & NA \\
\hline Total cores (no. & & & & & 1 & & & tal cores (no.): & & & 1 \\
\hline Hole U1501C & & & & & & & Hol & U1501D & & & \\
\hline Latitude: & & & & & $18^{\circ} 53.091$ & $9^{\prime} \mathrm{N}$ & & titude & & & $18^{\circ} 53.0929^{\prime} \mathrm{N}$ \\
\hline Longitude: & & & & & $115^{\circ} 45.948$ & $5^{\prime} \mathrm{E}$ & & ngitude & & & $115^{\circ} 45.9370^{\prime} \mathrm{E}$ \\
\hline Seafloor (drill $p$ & e meas & arement be & w rig floor, $\mathrm{m}$ & DRF): & 2845.81 & & & afloor (drill pipe me & asurement & selow rig floor, m DRF): & 2845.82 \\
\hline Time on hole (c & ys): & & & & 3.53 & & & ne on hole (days) & & & 5.15 \\
\hline Total depth (dri & pipe $m$ & asuremen & from rig floor, $\mathrm{m}$ & m DRF): 2 & 2856.7 & & & tal depth (drill pipe & measureme & nt from rig floor, $m$ DRF): $\quad 2$ & 2856.7 \\
\hline Distance betwe & $\mathrm{n}$ rig flo & or and sea & $\operatorname{vel}(m)$ : & & 10.89 & & & stance between rig & loor and se & a level (m): & 10.88 \\
\hline Total penetratic & (drillin & depth be & w seafloor, $\mathrm{m} \mathrm{D}$ & DSF): & 461.9 & & & tal penetration (dril & ing depth $b$ & elow seafloor, m DSF): & 644.3 \\
\hline Total length of & pred sec & ion $(m)$ : & & & 461.9 & & & tal length of cored & ection (m): & & 210.8 \\
\hline Total core reco & $\mathrm{red}(\mathrm{m})$ & & & & 444.77 & & & tal core recovered ( & & & 78.77 \\
\hline Core recovery ( & & & & & 96.29 & & & re recovery (\%): & & & 37.37 \\
\hline Drilled interval & & & & & NA & & & illed interval (m) & & & 433.5 \\
\hline Total cores (no. & & & & & 62 & & & tal cores (no.) & & & 26 \\
\hline Core & Type & $\begin{array}{l}\text { Top of } \\
\text { interval } \\
\text { DSF }(m)\end{array}$ & $\begin{array}{l}\text { Bottom of } \\
\text { interval } \\
\text { DSF }(m)\end{array}$ & $\begin{array}{l}\text { Interval } \\
\text { advanced } \\
\text { (m) }\end{array}$ & $\begin{array}{l}\text { Core } \\
\text { recovered } \\
\text { length }(m)\end{array}$ & $\begin{array}{l}\text { Curated } \\
\text { length } \\
\text { (m) }\end{array}$ & $\begin{array}{c}\text { Recovery } \\
(\%)\end{array}$ & $\begin{array}{l}\text { Time on } \\
\text { deck UTC } \\
\text { (h) }\end{array}$ & $\begin{array}{l}\text { Time to } \\
\text { cut core } \\
\text { (min) }\end{array}$ & $\begin{array}{l}\text { Mud } \\
\text { pumped } \\
\text { (bbl) }\end{array}$ & Driller's notes \\
\hline $368-U 15$ & $1 \mathrm{~A}-$ & & & & & & & & & & \\
\hline 1 & $\mathrm{H}$ & 0.00 & 9.5 & 9.5 & 9.73 & 9.73 & 102 & 4/15/2017 16:10 & & Nonmagnetic & \\
\hline & & Hole & 1501A totals: & 9.5 & 9.73 & 9.73 & 102 & & & & \\
\hline $368-U 15$ & 1B- & & & & & & & & & & \\
\hline 1 & $\mathrm{H}$ & 0.00 & 9.5 & 9.5 & 9.83 & 9.83 & 103 & 4/15/2017 17:25 & & Nonmagnetic & \\
\hline & & Hole & 1501B totals: & 9.5 & 9.83 & 9.83 & 103 & & & & \\
\hline $368-U 15$ & $1 C-$ & & & & & & & & & & \\
\hline 1 & $\mathrm{H}$ & 0.0 & 9.3 & 9.3 & 9.24 & 9.24 & 99 & $4 / 15 / 201721: 30$ & & Nonmagnetic & \\
\hline 2 & $\mathrm{H}$ & 9.3 & 18.8 & 9.5 & 8.68 & 8.68 & 91 & $4 / 15 / 201722: 35$ & 5 & Nonmagnetic & \\
\hline 3 & $\mathrm{H}$ & 18.8 & 28.3 & 9.5 & 9.76 & 9.76 & 103 & $4 / 15 / 201723: 35$ & 5 & Nonmagnetic & \\
\hline 4 & $\mathrm{H}$ & 28.3 & 37.8 & 9.5 & 9.78 & 9.78 & 103 & $4 / 16 / 201700: 20$ & 5 & Nonmagnetic & \\
\hline 5 & $\mathrm{H}$ & 37.8 & 47.3 & 9.5 & 9.15 & 9.15 & 96 & 4/16/2017 01:30 & 5 & Nonmagnetic & APCT-3 \\
\hline 6 & $\mathrm{H}$ & 47.3 & 56.8 & 9.5 & 9.77 & 9.77 & 103 & 4/16/2017 02:25 & 5 & Nonmagnetic & \\
\hline 7 & $\mathrm{H}$ & 56.8 & 66.3 & 9.5 & 9.42 & 9.42 & 99 & 4/16/2017 03:30 & 5 & Nonmagnetic & \\
\hline 8 & $\mathrm{H}$ & 66.3 & 75.8 & 9.5 & 9.51 & 9.51 & 100 & 4/16/2017 04:45 & 5 & Nonmagnetic & APCT-3 \\
\hline 9 & $\mathrm{H}$ & 75.8 & 85.3 & 9.5 & 9.70 & 9.70 & 102 & $4 / 16 / 2017$ 05:40 & 5 & Nonmagnetic & \\
\hline 10 & $\mathrm{H}$ & 85.3 & 94.8 & 9.5 & 9.61 & 9.61 & 101 & $4 / 16 / 201706: 25$ & 5 & Nonmagnetic & \\
\hline 11 & $\mathrm{H}$ & 94.8 & 104.3 & 9.5 & 10.11 & 10.11 & 106 & 4/16/2017 07:50 & 5 & Nonmagnetic & APCT-3 \\
\hline 12 & $\mathrm{H}$ & 104.3 & 113.8 & 9.5 & 9.67 & 9.67 & 102 & 4/16/2017 09:00 & 5 & Nonmagnetic & \\
\hline 13 & $\mathrm{H}$ & 113.8 & 123.3 & 9.5 & 10.03 & 10.03 & 106 & 4/16/2017 09:50 & 5 & Nonmagnetic & \\
\hline 14 & $\mathrm{H}$ & 123.3 & 132.8 & 9.5 & 8.23 & 8.23 & 87 & 4/16/2017 11:05 & 10 & Nonmagnetic & APCT-3 \\
\hline 15 & $\mathrm{H}$ & 132.8 & 142.3 & 9.5 & 9.39 & 9.39 & 99 & 4/16/2017 12:10 & 10 & Nonmagnetic & \\
\hline 16 & $\mathrm{H}$ & 142.3 & 151.8 & 9.5 & 9.50 & 9.50 & 100 & & 10 & Nonmagnetic & \\
\hline 17 & $\mathrm{H}$ & 151.8 & 156.8 & 5.0 & 4.95 & 4.95 & 99 & 4/16/2017 14:15 & 10 & Nonmagnetic & \\
\hline
\end{tabular}


Table T1 (continued). (Continued on next page.)

\begin{tabular}{|c|c|c|c|c|c|c|c|c|c|c|c|c|}
\hline Core & Type & $\begin{array}{l}\text { Top of } \\
\text { interval } \\
\text { DSF (m) }\end{array}$ & $\begin{array}{l}\text { Bottom of } \\
\text { interval } \\
\text { DSF }(m)\end{array}$ & $\begin{array}{l}\text { Interval } \\
\text { advanced } \\
\text { (m) }\end{array}$ & $\begin{array}{l}\text { Core } \\
\text { recovered } \\
\text { length }(\mathrm{m})\end{array}$ & $\begin{array}{l}\text { Curated } \\
\text { length } \\
\text { (m) }\end{array}$ & $\begin{array}{l}\text { Recovery } \\
(\%)\end{array}$ & $\begin{array}{c}\text { Time on } \\
\text { deck UTC } \\
\text { (h) }\end{array}$ & $\begin{array}{l}\text { Time to } \\
\text { cut core } \\
\text { (min) }\end{array}$ & $\begin{array}{l}\text { Core } \\
\text { barrel }\end{array}$ & $\begin{array}{c}\text { Mud } \\
\text { pumped } \\
\text { (bbl) }\end{array}$ & Driller's notes \\
\hline 18 & $\mathrm{~F}$ & 156.8 & 161.5 & 4.7 & 4.92 & 4.92 & 105 & 4/16/2017 15:40 & 5 & Nonmagnetic & & \\
\hline 19 & $\mathrm{~F}$ & 161.5 & 166.2 & 4.7 & 4.80 & 4.80 & 102 & 4/16/2017 16:30 & 10 & Nonmagnetic & & \\
\hline 20 & $\mathrm{~F}$ & 166.2 & 170.9 & 4.7 & 3.77 & 3.77 & 80 & 4/16/2017 17:20 & 5 & Nonmagnetic & & \\
\hline 21 & $\mathrm{~F}$ & 170.9 & 175.6 & 4.7 & 5.07 & 5.07 & 108 & 4/16/2017 18:10 & 10 & Nonmagnetic & & \\
\hline 22 & $\mathrm{~F}$ & 175.6 & 180.3 & 4.7 & 5.00 & 5.00 & 106 & 4/16/2017 19:00 & 5 & Nonmagnetic & & \\
\hline 23 & $\mathrm{~F}$ & 180.3 & 185.0 & 4.7 & 4.15 & 4.15 & 88 & 4/16/2017 19:50 & 10 & Nonmagnetic & & \\
\hline 24 & $\mathrm{~F}$ & 185.0 & 189.7 & 4.7 & 4.47 & 4.47 & 95 & $4 / 16 / 201720: 45$ & 5 & Nonmagnetic & & \\
\hline 25 & $\mathrm{~F}$ & 189.7 & 194.4 & 4.7 & 3.65 & 3.65 & 78 & 4/16/2017 21:35 & 10 & Nonmagnetic & & \\
\hline 26 & $\mathrm{~F}$ & 194.4 & 199.1 & 4.7 & 3.98 & 3.98 & 85 & 4/16/2017 22:20 & 5 & Nonmagnetic & & \\
\hline 27 & $\mathrm{~F}$ & 199.1 & 203.8 & 4.7 & 4.98 & 4.98 & 106 & 4/16/2017 23:20 & 10 & Nonmagnetic & 15 & \\
\hline 28 & $\mathrm{~F}$ & 203.8 & 208.5 & 4.7 & 4.90 & 4.90 & 104 & 4/17/2017 00:10 & 5 & Nonmagnetic & & \\
\hline 29 & $\mathrm{~F}$ & 208.5 & 213.2 & 4.7 & 4.22 & 4.22 & 90 & 4/17/2017 01:05 & 10 & Nonmagnetic & & \\
\hline 30 & $\mathrm{~F}$ & 213.2 & 217.9 & 4.7 & 4.39 & 4.39 & 93 & 4/17/2017 01:50 & 5 & Nonmagnetic & & \\
\hline 31 & $\mathrm{~F}$ & 217.9 & 222.6 & 4.7 & 3.68 & 3.68 & 78 & 4/17/2017 02:40 & 10 & Nonmagnetic & & \\
\hline 32 & $\mathrm{~F}$ & 222.6 & 227.3 & 4.7 & 3.87 & 3.87 & 82 & 4/17/2017 03:30 & 5 & Nonmagnetic & & \\
\hline 33 & $\mathrm{~F}$ & 227.3 & 232.0 & 4.7 & 4.53 & 4.53 & 96 & 4/17/2017 04:20 & 10 & Nonmagnetic & & \\
\hline 34 & $\mathrm{~F}$ & 232.0 & 236.7 & 4.7 & 3.72 & 3.72 & 79 & 4/17/2017 05:15 & 5 & Nonmagnetic & & \\
\hline 35 & $\mathrm{~F}$ & 236.7 & 241.4 & 4.7 & 3.43 & 3.43 & 73 & 4/17/2017 06:05 & 10 & Nonmagnetic & & \\
\hline 36 & $\mathrm{~F}$ & 241.4 & 246.1 & 4.7 & 3.88 & 3.88 & 83 & 4/17/2017 06:55 & 10 & Nonmagnetic & & \\
\hline 37 & $\mathrm{~F}$ & 246.1 & 250.8 & 4.7 & 3.25 & 3.25 & 69 & 4/17/2017 07:45 & 10 & Nonmagnetic & & \\
\hline 38 & $\mathrm{~F}$ & 250.8 & 255.5 & 4.7 & 2.72 & 2.72 & 58 & 4/17/2017 08:45 & 10 & Nonmagnetic & & \\
\hline 39 & $\mathrm{~F}$ & 255.5 & 257.0 & 1.5 & 1.36 & 1.36 & 91 & 4/17/2017 09:30 & 10 & Nonmagnetic & & \\
\hline 40 & $\mathrm{x}$ & 257.0 & 264.0 & 7.0 & 8.35 & 8.35 & 119 & 4/17/2017 11:20 & 35 & & & \\
\hline 41 & $\mathrm{x}$ & 264.0 & 273.7 & 9.7 & 9.91 & 9.91 & 102 & 4/17/2017 12:45 & 40 & & & \\
\hline 42 & $x$ & 273.7 & 283.3 & 9.6 & 9.76 & 9.76 & 102 & 4/17/2017 14:05 & 30 & & & \\
\hline 43 & $\mathrm{x}$ & 283.3 & 292.9 & 9.6 & 9.85 & 9.85 & 103 & 4/17/2017 15:30 & 35 & & & \\
\hline 44 & $\mathrm{x}$ & 292.9 & 302.5 & 9.6 & 9.66 & 9.66 & 101 & 4/17/2017 16:50 & 30 & & & \\
\hline 45 & $\mathrm{x}$ & 302.5 & 312.1 & 9.6 & 9.70 & 9.70 & 101 & 4/17/2017 18:15 & 40 & & & \\
\hline 46 & $\mathrm{x}$ & 312.1 & 321.7 & 9.6 & 9.71 & 9.71 & 101 & 4/17/2017 19:40 & 30 & & & \\
\hline 47 & $x$ & 321.7 & 331.3 & 9.6 & 9.48 & 9.48 & 99 & 4/17/2017 21:15 & 45 & & & \\
\hline 48 & $\mathrm{x}$ & 331.3 & 340.8 & 9.5 & 9.13 & 9.16 & 96 & 4/17/2017 23:10 & 40 & & 15 & \\
\hline 49 & $x$ & 340.8 & 350.4 & 9.6 & 9.65 & 9.69 & 101 & 4/18/2017 00:50 & 40 & & & \\
\hline 50 & $\mathrm{x}$ & 350.4 & 360.0 & 9.6 & 9.21 & 9.28 & 96 & 4/18/2017 02:20 & 40 & & & \\
\hline 51 & $x$ & 360.0 & 369.6 & 9.6 & 9.88 & 9.98 & 103 & 4/18/2017 03:40 & 35 & & & \\
\hline 52 & $\mathrm{x}$ & 369.6 & 379.2 & 9.6 & 9.97 & 10.04 & 104 & 4/18/2017 05:10 & 45 & & & \\
\hline 53 & $\mathrm{x}$ & 379.2 & 388.8 & 9.6 & 6.13 & 6.13 & 64 & 4/18/2017 06:50 & 50 & & & \\
\hline 54 & $x$ & 388.8 & 398.4 & 9.6 & 9.99 & 9.99 & 104 & 4/18/2017 08:40 & 50 & & 20 & \\
\hline 55 & $\mathrm{x}$ & 398.4 & 408.0 & 9.6 & 9.90 & 9.90 & 103 & 4/18/2017 10:25 & 45 & & & \\
\hline 56 & $x$ & 408.0 & 417.6 & 9.6 & 9.85 & 9.85 & 103 & 4/18/2017 12:45 & 55 & & & \\
\hline 57 & $x$ & 417.6 & 427.2 & 9.6 & 9.99 & 10.02 & 104 & 4/18/2017 14:35 & 50 & & 20 & \\
\hline 58 & $\mathrm{x}$ & 427.2 & 436.8 & 9.6 & 9.92 & 9.92 & 103 & 4/18/2017 16:10 & 45 & & & \\
\hline 59 & $\mathrm{x}$ & 436.8 & 446.3 & 9.5 & 9.90 & 9.90 & 104 & 4/18/2017 17:35 & 35 & & & \\
\hline 60 & $\mathrm{x}$ & 446.3 & 448.3 & 2.0 & 1.67 & 1.67 & 84 & 4/18/2017 18:50 & 15 & & & \\
\hline 61 & $\mathrm{x}$ & 448.3 & 454.9 & 6.6 & 4.72 & 4.72 & 72 & $4 / 18 / 201720: 50$ & 60 & & & \\
\hline 62 & $\mathrm{x}$ & 454.9 & 461.9 & 7.0 & 3.20 & 3.20 & 46 & $4 / 18 / 201722: 50$ & 60 & & & \\
\hline \multicolumn{5}{|c|}{ Hole U1501C totals: 461.9} & 444.77 & 445.11 & 96.37 & & & & & \\
\hline \multicolumn{13}{|c|}{ 368-U1501D- } \\
\hline 1 & 1 & 0.0 & 433.5 & 433.5 & \multicolumn{3}{|c|}{${ }^{* * * * * \text { Drilled interval }}{ }^{* * * *}$} & $4 / 20 / 201722: 45$ & 540 & Nonmagnetic & 150 & \\
\hline 2 & $\mathrm{R}$ & 433.5 & 443.1 & 9.6 & 7.62 & 7.62 & 79 & 4/21/2017 00:35 & 30 & Nonmagnetic & & \\
\hline 3 & $\mathrm{R}$ & 443.1 & 452.6 & 9.5 & 5.19 & 5.19 & 55 & 4/21/2017 02:10 & 50 & Nonmagnetic & & \\
\hline 4 & $\mathrm{R}$ & 452.6 & 462.2 & 9.6 & 1.84 & 1.84 & 19 & 4/21/2017 03:45 & 50 & Nonmagnetic & 15 & \\
\hline 5 & $\mathrm{R}$ & 462.2 & 471.8 & 9.6 & 0.48 & 0.48 & 5 & 4/21/2017 04:55 & 25 & Nonmagnetic & & \\
\hline 6 & $\mathrm{R}$ & 471.8 & 481.4 & 9.6 & 0.15 & 0.15 & 2 & $4 / 21 / 201706: 00$ & 5 & Nonmagnetic & & \\
\hline 7 & $\mathrm{R}$ & 481.4 & 491.0 & 9.6 & 0.95 & 0.95 & 10 & 4/21/2017 07:40 & 45 & Nonmagnetic & 15 & \\
\hline 8 & $\mathrm{R}$ & 491.0 & 500.6 & 9.6 & 1.64 & 1.64 & 17 & 4/21/2017 08:35 & 5 & Nonmagnetic & & \\
\hline 9 & $\mathrm{R}$ & 500.6 & 510.2 & 9.6 & 1.22 & 1.22 & 13 & 4/21/2017 09:25 & 5 & Nonmagnetic & & \\
\hline 10 & $\mathrm{R}$ & 510.2 & 519.7 & 9.5 & 0.94 & 0.94 & 10 & 4/21/2017 11:25 & 75 & Nonmagnetic & 15 & \\
\hline 11 & $\mathrm{R}$ & 519.7 & 529.3 & 9.6 & 0.12 & 0.12 & 1 & 4/21/2017 12:35 & 10 & Nonmagnetic & & \\
\hline 12 & $\mathrm{R}$ & 529.3 & 539.0 & 9.7 & 0.13 & 0.13 & 1 & 4/21/2017 14:10 & 20 & Nonmagnetic & 20 & \\
\hline 13 & $\mathrm{R}$ & 539.0 & 548.6 & 9.6 & 1.05 & 1.05 & 11 & $4 / 21 / 201715: 50$ & 45 & Nonmagnetic & & \\
\hline 14 & $\mathrm{R}$ & 548.6 & 558.2 & 9.6 & 0.74 & 0.74 & 8 & 4/21/2017 18:30 & 20 & Nonmagnetic & 20 & \\
\hline 15 & $\mathrm{R}$ & 558.2 & 567.8 & 9.6 & 4.44 & 4.44 & 46 & 4/21/2017 19:35 & 15 & Nonmagnetic & & \\
\hline 16 & $\mathrm{R}$ & 567.8 & 577.4 & 9.6 & 6.08 & 6.08 & 63 & $4 / 21 / 201720: 50$ & 25 & Nonmagnetic & & \\
\hline 17 & $\mathrm{R}$ & 577.4 & 586.9 & 9.5 & 5.39 & 5.39 & 57 & $4 / 21 / 201722: 20$ & 40 & Nonmagnetic & 20 & \\
\hline 18 & $\mathrm{R}$ & 586.9 & 596.5 & 9.6 & 4.51 & 4.51 & 47 & $4 / 21 / 201723: 25$ & 20 & Nonmagnetic & & \\
\hline 19 & $\mathrm{R}$ & 596.5 & 606.1 & 9.6 & 3.45 & 3.45 & 36 & 4/22/2017 01:15 & 75 & Nonmagnetic & & \\
\hline 20 & $\mathrm{R}$ & 606.1 & 609.6 & 3.5 & 4.11 & 4.11 & 117 & 4/22/2017 04:20 & 100 & Nonmagnetic & 20 & \\
\hline
\end{tabular}


Table T1 (continued).

\begin{tabular}{|c|c|c|c|c|c|c|c|c|c|c|c|c|}
\hline Core & Type & $\begin{array}{c}\text { Top of } \\
\text { interval } \\
\text { DSF }(m)\end{array}$ & $\begin{array}{l}\text { Bottom of } \\
\text { interval } \\
\text { DSF (m) }\end{array}$ & $\begin{array}{l}\text { Interval } \\
\text { advanced } \\
\text { (m) }\end{array}$ & $\begin{array}{c}\text { Core } \\
\text { recovered } \\
\text { length }(\mathrm{m})\end{array}$ & $\begin{array}{l}\text { Curated } \\
\text { length } \\
\text { (m) }\end{array}$ & $\begin{array}{l}\text { Recovery } \\
(\%)\end{array}$ & $\begin{array}{l}\text { Time on } \\
\text { deck UTC } \\
\text { (h) }\end{array}$ & $\begin{array}{l}\text { Time to } \\
\text { cut core } \\
\text { (min) }\end{array}$ & $\begin{array}{l}\text { Core } \\
\text { barrel }\end{array}$ & $\begin{array}{c}\text { Mud } \\
\text { pumped } \\
\text { (bbl) }\end{array}$ & Driller's notes \\
\hline 21 & $\mathrm{R}$ & 609.6 & 615.7 & 6.1 & 5.07 & 5.07 & 83 & 4/22/2017 07:15 & 140 & Nonmagnetic & & \\
\hline 22 & $\mathrm{R}$ & 615.7 & 620.2 & 4.5 & 3.98 & 3.98 & 88 & 4/22/2017 11:15 & 150 & Nonmagnetic & & \\
\hline 23 & $\mathrm{R}$ & 620.2 & 625.2 & 5.0 & 4.94 & 4.94 & 99 & 4/22/2017 17:05 & 255 & Nonmagnetic & & \\
\hline 24 & $\mathrm{R}$ & 625.2 & 629.7 & 4.5 & 4.23 & 4.23 & 94 & 4/22/2017 21:30 & 180 & Nonmagnetic & & \\
\hline 25 & $\mathrm{R}$ & 629.7 & 634.7 & 5.0 & 2.68 & 2.68 & 54 & 4/23/2017 01:15 & 140 & Nonmagnetic & & \\
\hline 26 & $\mathrm{R}$ & 634.7 & 639.2 & 4.5 & 3.46 & 3.46 & 77 & 4/23/2017 05:50 & 190 & Nonmagnetic & 20 & \\
\hline 27 & $\mathrm{R}$ & 639.2 & 644.3 & 5.1 & 4.36 & 4.36 & 85 & 4/23/2017 09:50 & 110 & Nonmagnetic & 40 & \\
\hline \multicolumn{5}{|c|}{$\begin{array}{c}\text { Hole U1501D totals including drilled } 644.3 \\
\text { interval: }\end{array}$} & 78.77 & 78.77 & 12.23 & & & & & \\
\hline \multicolumn{5}{|c|}{$\begin{array}{c}\text { Hole U1501D totals excluding drilled } 210.8 \\
\text { interval: }\end{array}$} & 78.77 & 78.77 & 37.37 & & & & & \\
\hline
\end{tabular}

ing, they were introduced to life on board the R/V JOIDES Resolution and participated in the laboratory and ship safety tours. Loading and offloading operations continued with the loading of 40 short tons of sepiolite and the containerized science ocean freight, along with fresh and refrigerated food products and 300 metric tons of potable water. Cores from the two previous expeditions (366 and 367) were offloaded from the vessel and loaded into refrigerated containers for shipment to the Kochi Core Center (Japan) and Gulf Coast Repository (US), respectively. Ninety joints of $5 \frac{1}{2}$ inch drill pipe were offloaded to the pier, and another 72 were broken down and stowed on the riser hold hatch.

On 11 April, major port call activities included loading of 1212 metric tons of marine gas oil and 40 short tons of sepiolite mud (total $=\sim 80$ short tons). All dry food for Expedition 368 was loaded. The rest of the 204 joints of $5 \frac{1}{2}$ inch drill pipe were broken down and offloaded to the pier to be returned for inspection and refurbishment. The vessel continued conducting annual class, radio, and lifeboat surveys. Tours were conducted for members of the Hong Kong Sea Cadet Corps and Hong Kong Baptist University.

On 12 April, casing-loading operations were initiated and tours were conducted for students and faculty from the Southern University of Science and Technology. On 13 April, casing-loading operations were completed. Mud motors, underreamers, and reentry equipment were all loaded and stowed for transit. Annual lifeboat inspections and all other certifications were completed. All equipment was secured for sailing.

At $0600 \mathrm{~h}$ on 14 April, Hong Kong immigration authorities boarded the ship and cleared the personnel and vessel for departure. The harbor pilot arrived on board shortly after $0900 \mathrm{~h}$, and with assistance from two harbor tugs, the JOIDES Resolution was underway, with the last line released at $0912 \mathrm{~h}$. We proceeded to the pilot station, and after a $6 \mathrm{nmi}$ transit, the pilot disembarked the ship at $0954 \mathrm{~h}$. The sea voyage continued for the next $24 \mathrm{~h}$. During the transit, the Co-Chief Scientists presented the scientific objectives for Site U1501 and the Captain held the first fire and boat safety drill. Later that day, the Co-Chief Scientists, key JOIDES Resolution Science Operator staff, and ship's crew met to review the coring and logging plan for Site U1501. The scientists moved into their working shifts, and the noon-to-midnight shift resumed laboratory activities. The $255 \mathrm{nmi}$ transit from Hong Kong to Site U1501 was completed at $0837 \mathrm{~h}$ on 15 April at an average speed of $10.6 \mathrm{kt}$.

\section{Holes U1501A-U1501C}

After arriving at Site U1501, we lowered the thrusters, deployed a seafloor beacon, and put together the APC/XCB bottom-hole assembly (BHA) and started lowering it to the seafloor (2857 mbsl) in preparation for coring. The calculated precision depth recorder (PDR) depth for the seafloor at Site U1501 was 2873.4 meters below rig floor (mbrf), and we chose to place the bit at $2868 \mathrm{mbrf}$ to take the first core. An APC core barrel was lowered to the bit, and coring in Hole U1501A started at 2345 h on 15 April 2017. The mudline core recovered $9.5 \mathrm{~m}$ of sediment, and the seafloor depth was calculated to be $2868 \mathrm{mbrf}$ ( $2857.1 \mathrm{mbsl})$. Hole U1501A was terminated at $0025 \mathrm{~h}$ on 16 April, and the drill string was repositioned to attempt to core a better mudline at the site. With the bit at $2863 \mathrm{mbrf}$, we started Hole U1501B at $0100 \mathrm{~h}$ and again recovered a full core barrel, indicating once again that the APC was fired at or below the seafloor, and Hole U1501B was terminated. The vessel was offset 10 $\mathrm{m}$ east. The bit was raised to $2843 \mathrm{mbrf}$ in an attempt to start Hole $\mathrm{U} 1501 \mathrm{C}$, but the core barrel was retrieved empty. We then lowered the bit to 2848 mbrf for a second spud attempt at $0300 \mathrm{~h}$ and retrieved another empty core barrel. We then lowered the bit to 2856.4 mbrf and successfully spudded Hole U1501C at 0510 h, recovering $9.3 \mathrm{~m}$ of core and establishing a seafloor depth at 2856.7 mbrf (2845.8 mbsl).

Hole U1501C was cored to $156.8 \mathrm{~m}$ using the full-length APC coring system. The half-length APC (HLAPC) was deployed to deepen the hole to HLAPC refusal at $257 \mathrm{~m}$. We changed to the XCB system and deepened the hole to a final depth of $469.1 \mathrm{~m}$. Nonmagnetic core barrels were used on all cores. All full-length APC cores were oriented using the Icefield MI-5 core orientation tool. The APC system recovered $156.5 \mathrm{~m}$ of core (100\%). Temperature measurements were taken on Cores $5 \mathrm{H}(47.3 \mathrm{~m}), 8 \mathrm{H}(75.8 \mathrm{~m})$, $11 \mathrm{H}(104.3 \mathrm{~m})$, and $14 \mathrm{H}(132.8 \mathrm{~m})$. Partial strokes were recorded on Cores $16 \mathrm{H}$ and $17 \mathrm{H}$ (151.8 and $156.8 \mathrm{~m}$, respectively). The HLAPC system penetrated $100.2 \mathrm{~m}$ and recovered $88.54 \mathrm{~m}$ (88\%). Partial strokes were recorded on Cores $22 \mathrm{~F}(180.3 \mathrm{~m})$ and $25 \mathrm{~F}$ through $39 \mathrm{~F}$ (189.7-257.0 m). The bit was advanced $4.7 \mathrm{~m}$ after each core despite the partial strokes and $1.5 \mathrm{~m}$ after Core 39F.

The XCB system was deployed to core to refusal, recovering $199.5 \mathrm{~m}$ (97\%). A hard layer was met at $383.5 \mathrm{~m}$ (Core 53X), and a small piece of sandstone was recovered in the cutting shoe after retrieving the core barrel. Core recovery after that consisted of mudstone. Three more hard layers were found at 447.1, 454, and $460 \mathrm{~m}$. Refusal was reached after no advancement was accomplished for $\sim 10 \mathrm{~min}$ at $469.1 \mathrm{~m}$. There were no indications that casing would be needed to core deeper using the RCB system at this site. The bit was then retrieved to the rig floor, clearing the seafloor at $0935 \mathrm{~h}$ and clearing the rotary table at $1420 \mathrm{~h}$ on 19 April. Overall, 62 cores were taken over a $461.9 \mathrm{~m}$ interval with $444.8 \mathrm{~m}$ of recovery (96\%). Time spent in Hole U1501C was 84.75 h (3.5 days). 


\section{Hole U1501D}

The vessel was offset $20 \mathrm{~m}$ west for Hole U1501D. The RCB outer core barrel was set up in the rotary table, and the core barrels were spaced out. While making up the BHA, at $1600 \mathrm{~h}$ on 19 April 2017 a leak was detected in the low clutch diaphragm. The diaphragm was replaced and back on line by $0500 \mathrm{~h}$ on 20 April. The core barrels were prepared and spaced out, the remainder of the RCB BHA was made up, and the drill string was run in the hole to 2816 mbrf. The top drive was picked up, and the bit was spaced out to start Hole U1501D.

Hole U1501D was drilled without coring to $433.5 \mathrm{~m}$, and then $\mathrm{RCB}$ coring penetrated from that depth to $644.3 \mathrm{~m}$. The hole was conditioned for logging, the rotary shifting tool was run to release the bit, heavy mud was spotted at the bottom of the hole, the top drive was set back, and the bit was raised to $113 \mathrm{~m}$ for logging.

With an average heave of $<1 \mathrm{~m}$, the rig floor was set up for logging, and a modified triple combo tool string was made up and run into the open hole. During its descent, the tool string hung up at $\sim 3030$ mbrf $(173.3 \mathrm{~m})$. After six attempts, the tool string finally passed through the obstruction with significant drag and then continued downhole smoothly until it reached $3156 \mathrm{mbrf}$ (299.3 m). At that depth, the full weight of the tool hung up, and it would no longer advance. The consensus between the wireline engineer and the drilling and operations personnel was that the hole was collapsed and logging would have to be conducted from that depth upward.

During the logging run, there was significant overpull at $\sim 173.3$ $\mathrm{m}$. The caliper log indicated that the hole was collapsed to approximately the same diameter as the tool itself. It was deemed unsafe to go below that depth with any subsequent passes; therefore, the rest of the logging program was terminated. The drill pipe was recovered to the rig floor, clearing the seafloor at $1225 \mathrm{~h}$ on 24 April and the rotary table at $1715 \mathrm{~h}$.

A total of 90 cores were recorded for the site. The full-length APC system was deployed 19 times. The HLAPC system was deployed 22 times, the XCB coring system was deployed 23 times, and the RCB coring system was deployed 26 times. The total drilled interval was $433.5 \mathrm{~m}$ without recovery. The interval cored with the APC system was $175.8 \mathrm{~m}$ with a recovery of $176.6 \mathrm{~m}$ (100\%). The interval cored with the HLAPC system was $100.2 \mathrm{~m}$ with a recovery of $88.54 \mathrm{~m}$ (88\%). The interval cored with the XCB system was 204.9 $\mathrm{m}$ with a recovery of $199.53 \mathrm{~m}(97 \%)$. The RCB system cored 210.8 $\mathrm{m}$ and recovered $78.77 \mathrm{~m}$ (37\%). Total core recovered at Site U1501 was $543.10 \mathrm{~m}$, and the overall recovery was $79 \%$. Total time spent at Site U1501 was 224.75 h (9.4 days).

\section{Lithostratigraphy}

We constructed a composite lithostratigraphy by combining Holes U1501A-U1501D (Figure F7). We defined three lithostratigraphic units at Site U1501 based on visual core description, smear slide and thin section inspection, and X-ray diffraction (XRD) analysis (see Lithostratigraphy in the Expedition 367/368 methods chapter [Sun et al., 2018a]). The lithostratigraphic units and subunits are primarily defined by principal lithology. Several of the subunits exhibit gradual changes, complicating a sharp definition of their boundaries. The precise depth of boundaries between certain lithostratigraphic subunits in intervals of poor core recovery was difficult to determine; therefore, the boundaries were refined using physical property measurements (e.g., magnetic susceptibility, color reflectance spectroscopy, and seismic velocity) (see Physical prop- erties; also see Physical properties in the Expedition 367/368 methods chapter [Sun et al., 2018a]) and $\mathrm{CaCO}_{3}$ measurements in Figure F8.

The sedimentary succession recovered at Site U1501 extends from the pre-Cenozoic(?) to the Holocene and is dominated by clayrich nannofossil ooze, silty clay, clayey silt, sand, and sandstone. The succession is divided into three major lithostratigraphic units (I, II, and III) that are distinguished on the basis of sediment composition, particularly the relative abundance of calcareous and siliciclastic fractions. Unit I is dominated by clay-rich nannofossil ooze and nannofossil ooze with clay. The transition from Unit I to Unit II is abrupt and erosive and marked by a change from nannofossil-rich sediment in Unit I to siliciclastic-dominated clay, silt, and sand in Unit II.

The Unit II/III boundary was not recovered, but it is marked by an abrupt change in magnetic susceptibility, NGR, and $P$-wave velocity. Unit III is well lithified and comprises sandstone, sandstone with gravel, and minor conglomerate and laminated siltstone. Units I-III are further divided into several subunits.

\section{Unit descriptions}

\section{Unit I}

Intervals: $368-\mathrm{U} 1501 \mathrm{~A}-1 \mathrm{H}-1,0 \mathrm{~cm}$, to $1 \mathrm{H}-\mathrm{CC}, 14 \mathrm{~cm}$; $368-\mathrm{U} 1501 \mathrm{~B}-1 \mathrm{H}-1,0 \mathrm{~cm}$, to $1 \mathrm{H}-7,14 \mathrm{~cm}$; $368-\mathrm{U} 1501 \mathrm{C}-1 \mathrm{H}-1,0 \mathrm{~cm}$, to $45 \mathrm{X}-1,51 \mathrm{~cm}$

Depths: Hole U1501A = 0-9.73 m; Hole U1501B = 0-9.77 m; Hole U1501C $=0-303.01 \mathrm{~m}$

Age: Holocene to Oligocene

Lithology and sedimentary structures

Lithostratigraphic Unit I, in the upper part of the stratigraphy, was fully recovered in Hole U1501C. The top of Unit I was also recovered in Holes U1501A and U1501B. The dominant lithologies are clay-rich nannofossil ooze and nannofossil ooze with clay. Both lithologies can additionally have foraminifers, silt, or ash (e.g., "with foraminifers" as suffix) and minor amounts of nannofossil-rich foraminifer sand or silty sand. One discrete volcanic ash layer was found in Section 368-U1501A-1H-7, and an ash pod was found in Section 368-U1501C-3H-1. Ash is present in small amounts in some smear slides taken from other cores (e.g., Samples 368$\mathrm{U} 1501 \mathrm{C}-6 \mathrm{H}-5,88 \mathrm{~cm}$, and $6 \mathrm{H}-6,78 \mathrm{~cm})$. Unit I is divided into six subunits (IA-IF) based on minor changes in lithology and/or physical properties (Figure F9).

\section{Bulk mineralogy and chemistry}

The bulk mineralogy results of XRD analyses are listed in Table T2. Unit I sediments are composed mainly of calcite; halite; quartz; plagioclase; K-feldspar; clay minerals including smectite, illite, kaolinite, and/or chlorite; and minor amounts of pyrite. Calcite is present throughout Unit I (mostly in the form of nannofossils and foraminifers). Other minor minerals were observed in smear slides, but it was not possible to detect them through XRD analysis of bulk samples.

Figure F8 shows the downcore variations in the relative abundance of minerals identified by XRD in bulk sediments at Site U1501. The percentages of most terrigenous minerals in Unit I (quartz, plagioclase, authigenic halite, and clay minerals such as illite, kaolinite, and/or chlorite) decrease downcore, whereas calcite and pyrite increase. In contrast, K-feldspar decreases downcore for the upper $60 \mathrm{~m}$, increases between 60 and $140 \mathrm{~m}$, and then de- 
Figure F7. Lithostratigraphic summary of Site U1501 with simplified lithology and unit description of combined Holes U1501A-U1501C and U1501D. Upper cores are from Hole U1501C (1H through 61X); lower cores are from Hole U1501D (4R through 27R).

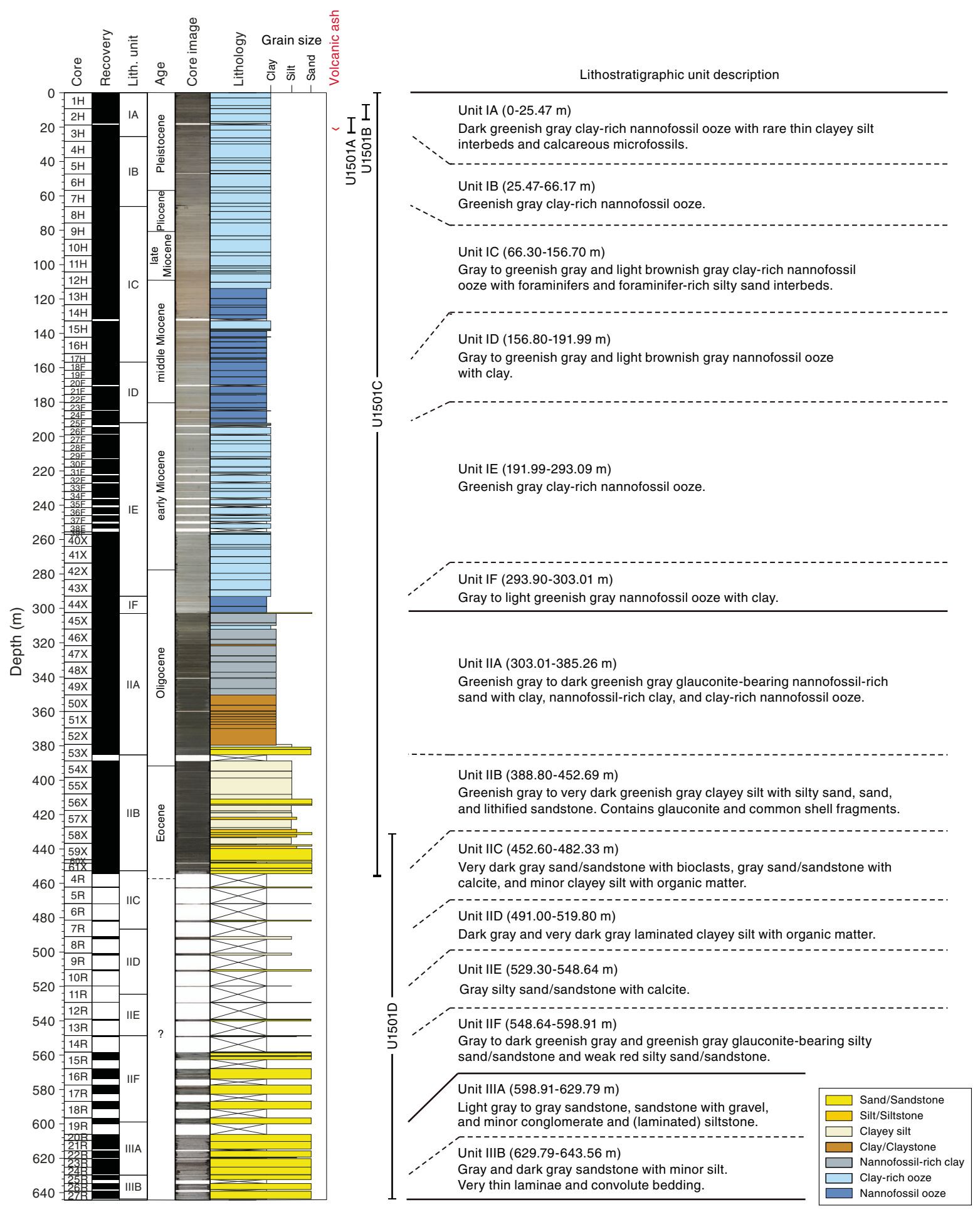

creases again from 140 to $280 \mathrm{~m}$. These general characteristics are consistent with the observed lithologic change from clay-rich nannofossil ooze to nannofossil ooze with clay.

Compositional analyses of the nannofossil ooze in Sections 368U1501C-44X-7, 44X-CC, and 45X-1 (Subunit IF) were made directly on the archive half of the core using the handheld portable $\mathrm{X}$ - ray fluorescence spectrometer (pXRF) (see Igneous and metamorphic petrology in the Expedition 367/368 methods chapter [Sun et al., 2018a]). The pXRF data are shown in Table T3. Eleven intervals of the nannofossil ooze show no variation in composition $(\mathrm{CaO}=$ 25-28 wt $\%, \mathrm{SiO}_{2}=\sim 20$ wt $\%$ and lower, $\mathrm{Al}_{2} \mathrm{O}_{3}=4-5 \mathrm{wt} \%, \mathrm{Fe}_{2} \mathrm{O}_{3}<2$ $\mathrm{wt} \%$, and $\mathrm{MgO}<2 \mathrm{wt} \%)$. The lowermost few centimeters of Subunit 
Figure F8. (A) Bulk mineralogy (XRD) and (B) carbonate content, Holes U1501C and U1501D.

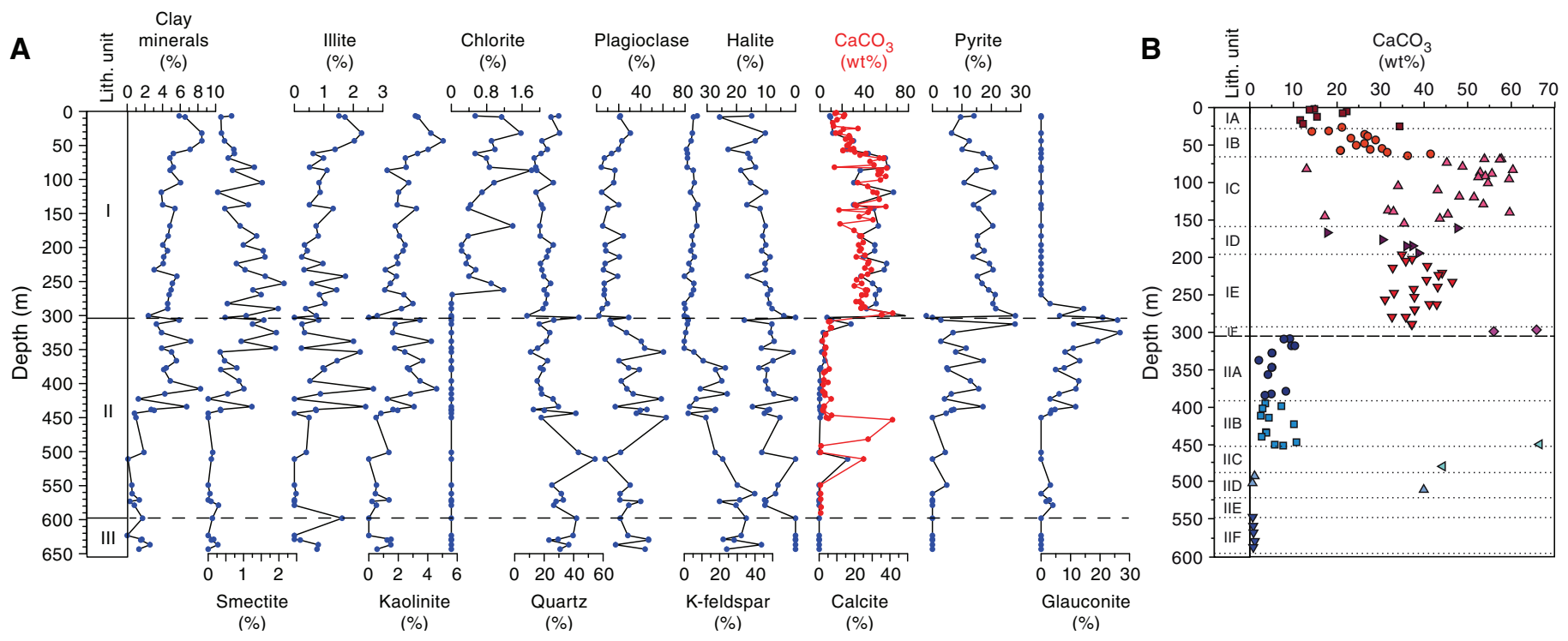

IF close to the contact with Unit II contain black sand and have lower $\mathrm{CaO}(\sim 18 \mathrm{wt} \%)$ and higher $\mathrm{SiO}_{2}, \mathrm{Al}_{2} \mathrm{O}_{3}$, and $\mathrm{Fe}_{2} \mathrm{O}_{3}(\sim 25 \mathrm{wt} \%$, $\sim 5 \mathrm{wt} \%$, and $\sim 3 \mathrm{wt} \%$, respectively). The dark nodules at the base of Subunit IF are iron and silica rich $\left(\mathrm{Fe}_{2} \mathrm{O}_{3}=\sim 10 \mathrm{wt} \%\right.$ and $\mathrm{SiO}_{2}=26$ wt\%). The $\mathrm{Zr}$ content of Subunit IF varies between 50 and $75 \mathrm{ppm}$. The ooze has high $\mathrm{Sr}(>750 \mathrm{ppm})$ and low $\mathrm{Ni}(<20 \mathrm{ppm})$ contents, whereas the nodules have low $\mathrm{Sr}(<100 \mathrm{ppm})$ and higher Ni $(100$ ppm) contents.

\section{Subunit IA}

\author{
Intervals: $368-\mathrm{U} 1501 \mathrm{~A}-1 \mathrm{H}-1,0 \mathrm{~cm}$, to $1 \mathrm{H}-\mathrm{CC}, 14 \mathrm{~cm}$; \\ 368-U1501B-1H-1, $0 \mathrm{~cm}$, to $1 \mathrm{H}-7,14 \mathrm{~cm}$; \\ $368-\mathrm{U} 1501 \mathrm{C}-1 \mathrm{H}-1,0 \mathrm{~cm}$, to $3 \mathrm{H}-5,84 \mathrm{~cm}$ \\ Depths: Hole U1501A = 0-9.73 m; Hole U1501B = 0-9.77 m; \\ Hole U1501C $=0-25.47 \mathrm{~m}$ \\ Age: Holocene to late Pleistocene
}

Subunit IA spans the uppermost $25.47 \mathrm{~m}$ of Unit I and is dominated by clay-rich calcareous ooze and clay-rich nannofossil ooze. The color of the ooze gradually changes from dark greenish gray to greenish gray. A distinct light-brown oxidized layer occurs at the top of this unit. The ooze comprises calcareous nannofossils and foraminifers, siliceous diatoms, sponge spicules, radiolarians, rare silicoflagellates, and terrigenous grains, including quartz, feldspar, clay minerals, and rare ferromagnesian minerals.

Bioturbation is moderate to heavy (apart from the slightly bioturbated top layer) with no clear layering visible. Individual burrows are difficult to distinguish but are mostly horizontal to inclined with recognizable Planolites, Thalassinoides, and Ophiomorpha (Figure F10). Distinct intervals (368-U1501C-1H-5, 6.0-6.5 cm, and $1 \mathrm{H}-5$, $7.5-8.5 \mathrm{~cm}$ ) contain more silt, and thin silt laminations are often disrupted by bioturbation (interval $3 \mathrm{H}-3,89-133 \mathrm{~cm}$ ).

Subunit IA has a discrete light gray silt-sized volcanic ash layer in interval 368-U1501A-1H-7A, 45-51 cm, and a centimeter-sized pod of volcanic ash in interval $368-\mathrm{U} 1501 \mathrm{C}-3 \mathrm{H}-1 \mathrm{~A}, 29 \mathrm{~cm}$. The ash is composed of silicic, platy, bubble wall, and lesser pumiceous glass shards and rare $(1 \%-5 \%)$ plagioclase crystals (Figure F11). Although the mudline was not recovered in Hole U1501A, the drilling $\log$ indicates that the drill string was raised by $10 \mathrm{~m}$ before drilling of Hole U1501C commenced. The ash layer is found at $9.05 \mathrm{~m}$ in Hole U1501A, which is consistent with the depth of the ash patch in Hole U1501C (19.08 m). Furthermore, because the ash texture and composition is similar in the two holes, we assume that both intervals are the deposit of the same eruption. No other discrete ash intervals were observed at Site U1501.

Subunit IA shows a gradual lithologic transition into Subunit IB but with a clear change in magnetic susceptibility, porosity, density, and seismic velocity. From this boundary, there is an upward increase in biogenic silica, including diatoms, sponge spicules, and radiolarians.

\section{Subunit IB}

Interval: $368-\mathrm{U} 1501 \mathrm{C}-3 \mathrm{H}-5,84 \mathrm{~cm}$, to $7 \mathrm{H}-\mathrm{CC}, 11 \mathrm{~cm}$

Depth: 25.47-66.17 m

Age: late Pleistocene to Pliocene

Subunit IB comprises a monotonous sequence of greenish gray and minor gray and dark greenish gray clay-rich nannofossil ooze. Minor dark greenish gray clay-rich nannofossil ooze with ash was found in Sections 6H-5 and 6H-6. The ooze comprises mainly calcareous nannofossils and foraminifers with minor quartz and clay minerals. Single foraminifer tests are visible on the core surface and become more abundant below Section 7H-3. Diagenetic pyrite grains are common.

The upper part of the subunit (Sections $3 \mathrm{H}-5$ through $3 \mathrm{H}-7$ ) is marked by slumping with inclined and convolute lamination and patchy color changes. Below these sections, bedding is difficult to determine due to lack of grain size or color variation and moderate bioturbation. Individual burrows are difficult to distinguish but are mostly horizontal to inclined with recognizable Planolites and Thalassinoides (Figure F10).

The base of Subunit IB is marked by both a color change to brown and light brownish sediment in Subunit IC and a lithologic change that reflects an increase in the percentage of foraminifers. This unit change is also seen in the progressive increase in measured carbonate content from $\sim 20 \mathrm{wt} \%$ at the top of Subunit IB to $\sim 40 \mathrm{wt} \%$ at the base (Figure F8). 
Figure F9. Simplified lithology and unit description overview, Unit I.

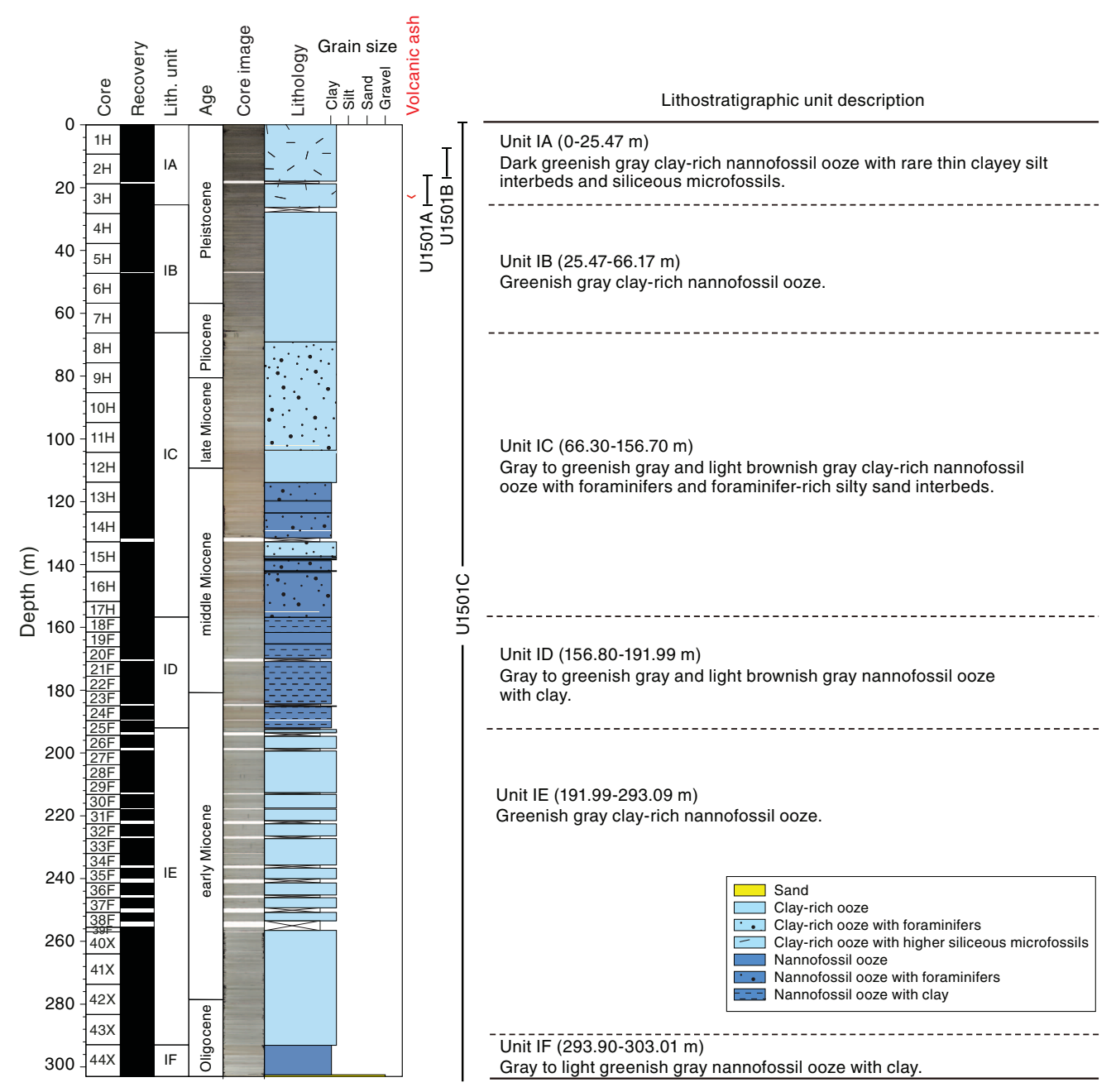

Table T2. Mineral percentages, Site U1501. View table in PDF format. Download table in CSV format.

Table T3. Major element oxides and minor elements in sediments, Site U1501. View table in PDF format. Download table in CSV format.

\section{Subunit IC}

Interval: $368-\mathrm{U} 1501 \mathrm{C}-8 \mathrm{H}-1,0 \mathrm{~cm}$, to $17 \mathrm{H}-4,60 \mathrm{~cm}$

Depth: 66.30-156.70 m

Age: Pliocene to middle Miocene

Subunit IC comprises an alternating sequence of gray, light gray, light brownish gray, greenish gray, and light greenish gray clay-rich nannofossil ooze with foraminifers; brown clay-rich nannofossil ooze with calcite; light brownish gray clay-rich nannofossil ooze and nannofossil ooze; light brownish gray silty sand; and greenish gray foraminifer-rich silty sand. The proportion of foraminifer-rich silty sand intervals increases from Core $16 \mathrm{H}$ to the base of the subunit.

Vague layering in the core is defined by color change. Boundaries between brownish and grayish intervals are mostly gradational, such as the color changes in Core 16H (Figure F12A), but sharp boundaries also occur, such as the one at Section 11H-6, $135 \mathrm{~cm}$. Variation in color may indicate grading with fining-upward intervals recognized in Cores $11 \mathrm{H}, 14 \mathrm{H}, 16 \mathrm{H}$, and $17 \mathrm{H}$ (Figure F12).
Boundaries are usually horizontal but are inclined in Sections $10 \mathrm{H}-$ 3 and $10 \mathrm{H}-4$, possibly indicating intraformational slumping. The number of sand-sized fining-upward laminations increases from Core $15 \mathrm{H}$ to Core $17 \mathrm{H}$.

Bioturbation varies from slight to heavy, but more intense bioturbation may be masked by the homogeneous sediment composition. Some burrows are filled with silty sand that consists mainly of foraminifers (Figure F10). Burrows are mostly horizontal to inclined, but some are vertical with recognizable Planolites.

The boundary between Subunits IC and ID is defined by a change in lithology from foraminifer-rich silty sand and nannofossil ooze with foraminifers (Subunit IC) to nannofossil ooze with clay (Subunit ID).

\section{Subunit ID}

Interval: $368-\mathrm{U} 1501 \mathrm{C}-18 \mathrm{~F}-1 \mathrm{~A}, 0 \mathrm{~cm}$, to $25 \mathrm{~F}-2,78 \mathrm{~cm}$

Depth: $156.80-191.99 \mathrm{~m}$

Age: middle to early Miocene

Subunit ID is dominated by nannofossil ooze with clay. The color changes gradually from the top of the subunit to the bottom from gray to light greenish gray to greenish gray to light brownish gray and gray. The sediment is well sorted and well consolidated. 
Figure F10. Diverse burrows, Hole U1501C. A. Thalassinoides. B, C. Pyritized burrows. D. Ophiomorpha or Cylindrichnus concentricus. E. Burrow filled with coarser sand.
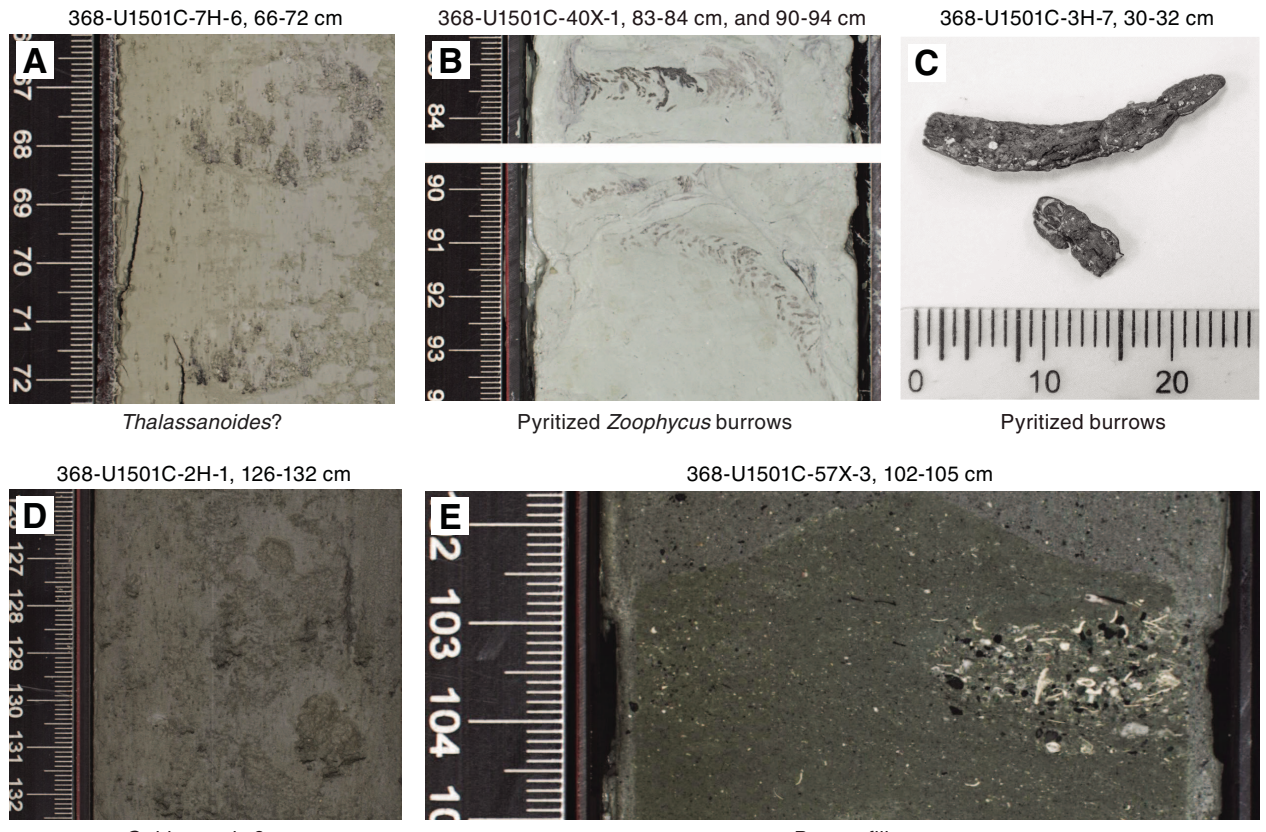

Cylindrichnus concentricus?

Burrow fill

Figure F11. A. Pale brownish ash layer (368-U1501A-1H-7, 45-51 cm), Subunit IA. B. Magnetic susceptibility of core interval with ash layer, Hole U1501A. The ash layer has a significantly higher magnetic susceptibility than the nannofossil ooze. C. Smear slide image of ash layer. The ash is compositionally dominated by transparent glass shards and rare colored minerals (feldspar and ferromagnesian minerals). D. Pale brownish ash patch (368-U1501C-3H-1, 29 cm), Subunit IA.
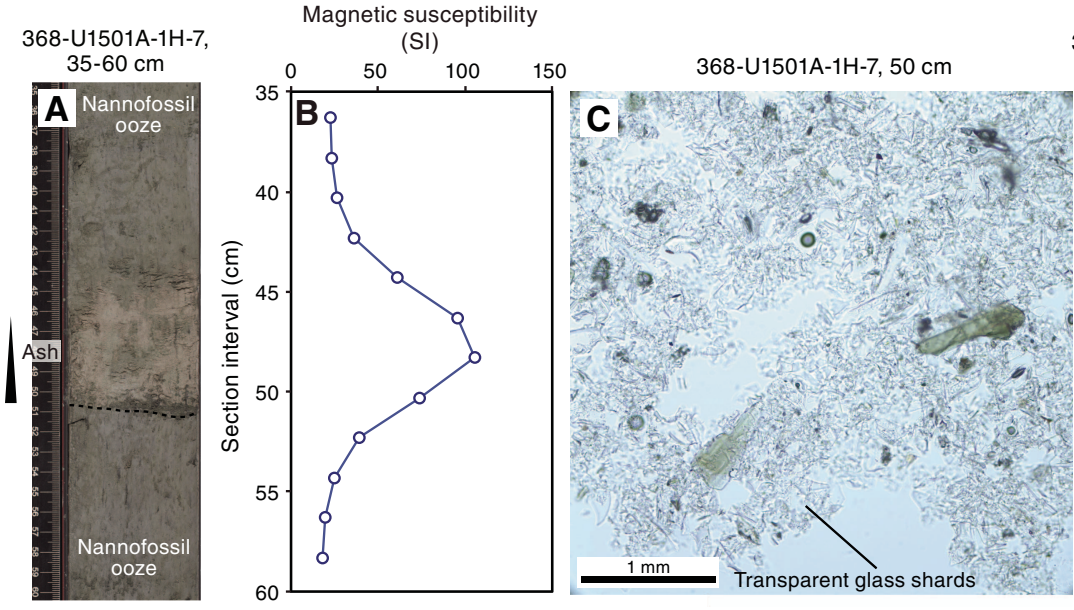

368-U1501C-3H-1, $15-40 \mathrm{~cm}$

The average grain size is clay, and fine sand is the maximum grain size.

Contacts between layers are planar or irregular inclined and gradational horizontal. Some contacts between layers are also bioturbated. Bioturbation in Subunit ID is moderate to heavy.

The sediment is dominated by clay minerals and calcareous nannofossils, but quartz crystals are common and rare foraminifers are present, as well as traces of organic matter and pyrite. Measured carbonate content ranges from 18 to 48 wt\% (Figure F8).

The lower boundary between Subunits ID and IE is characterized by a change in color and lithology, with more clay minerals in Subunit IE. A distinct increase in magnetic susceptibility and a slight decrease in NGR were observed at the transition.

\section{Subunit IE}

Interval: 368-U1501C-25F-2, $78 \mathrm{~cm}$, to $43 \mathrm{X}-\mathrm{CC}, 38 \mathrm{~cm}$

Depth: 191.99-293.09 m

Age: early Miocene to Oligocene

Subunit IE is composed of monotonous greenish gray clay-rich nannofossil ooze (Figure F13) that is well consolidated and well sorted with either silt or very fine sand as the maximum grain size. There is little perceptible variation in grain size, with only minor thin silt laminations. Contacts are horizontal and gradational. One thick $(\sim 1 \mathrm{~cm})$ lamination with upward fining was observed. Lightcolored foraminifer grains and pyrite were observed on the core surface. Pyrite also forms rare laminae. Another diagenetic feature 
Figure F12. Subunit IC. A. Core composite image. Red stars = thin finingupward intervals. These intervals are interpreted as distal turbidites. B. Fining-upward interval with sharp bottom contact and diffuse top.

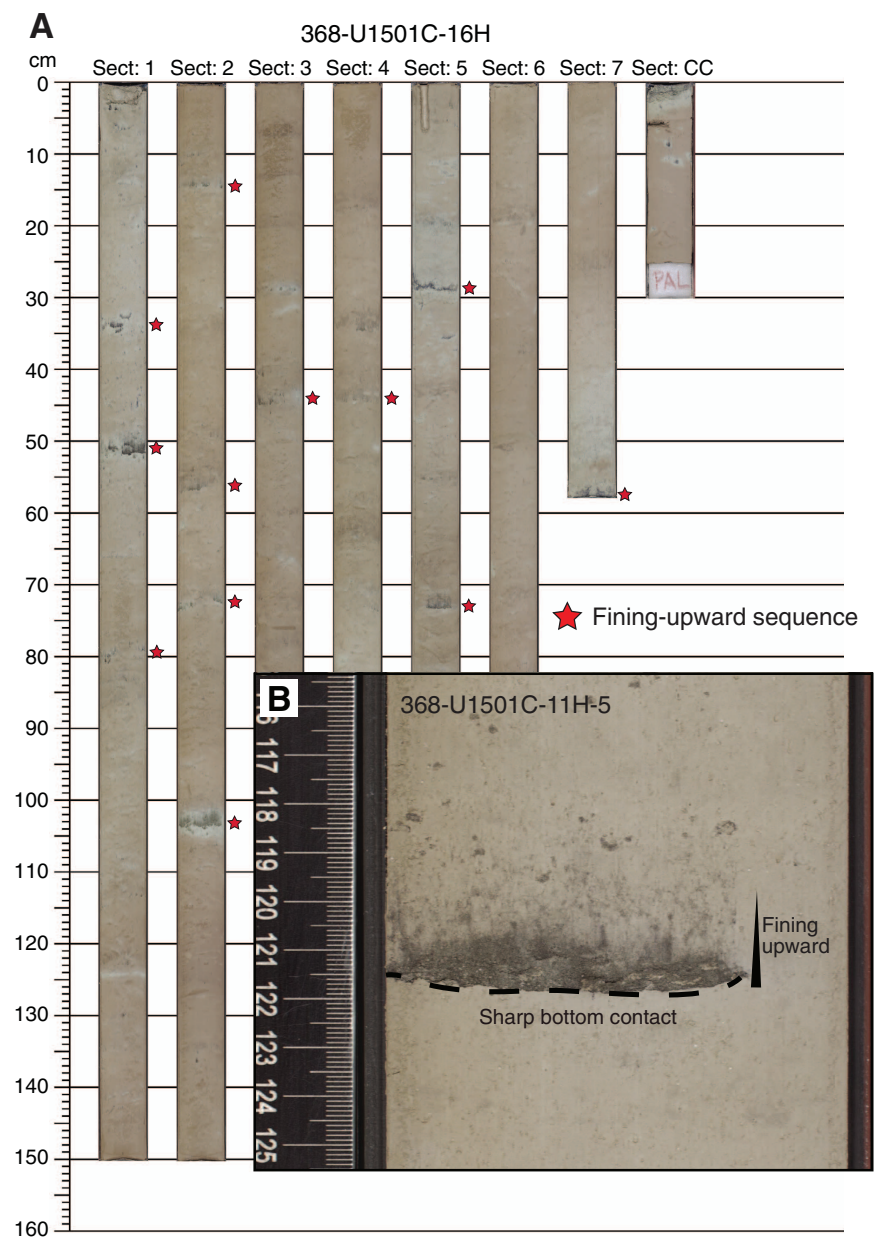

is a $1 \mathrm{~cm}$ wide patch of calcite or dolomite (interval 27F-1, 29-30 $\mathrm{cm}$ ). Bioturbation is moderate to high throughout the sequence, causing lens- and podlike textures.

The nannofossil ooze of Subunit IE exhibits consistently low magnetic susceptibility (less than $\left.-20 \times 10^{-5} \mathrm{SI}\right)$, low NGR $(<50$ counts/s), high bulk reflectance, and low red color (reflectance $\mathrm{a}^{*}$ ), which is consistent with dilution by high carbonate content (31-46 wt\%; Figure F8). Accordingly, nannofossils and foraminifers are common to abundant $(50 \%-75 \%)$, whereas the amounts of quartz $(<5 \%)$ and feldspar $(<5 \%)$ are low.

The lower contact to Subunit IF is marked by the occurrence of nannofossil ooze with clay and a color change to gray and light greenish gray. Drilling disturbance varies from slight to high, and "biscuits" are the most common disturbance type.

\section{Subunit IF}

Interval: $368-\mathrm{U} 1501 \mathrm{C}-44 \mathrm{X}-1,0 \mathrm{~cm}$, to $45 \mathrm{X}-1,51 \mathrm{~cm}$

Depth: 293.90-303.01 m

Age: Oligocene

Subunit IF is a short interval $(\sim 11 \mathrm{~m})$ of mainly gray to light greenish gray and greenish gray, well-sorted, well-consolidated nannofossil ooze with clay. The lowermost $\sim 51 \mathrm{~cm}$ (interval $45 \mathrm{X}-$ CC, $0-51 \mathrm{~cm}$ ) of this subunit is poorly sorted, matrix-supported
Figure F13. A. Clay-rich nannofossil ooze, Subunit IE. Monotonous sedimentation with pyrite patches. B. Close-up image (red square in A) of pyrite patches. C. Smear slide image of clay-rich nannofossil ooze with pyrite grains.

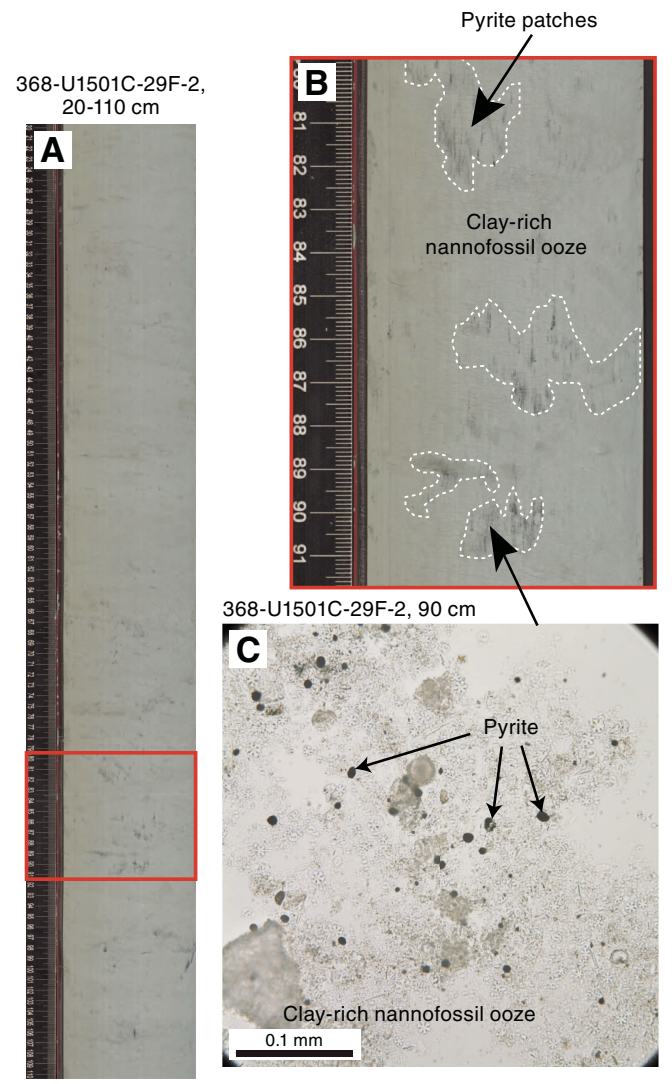

sand with gravel. The lithologic components are heterogeneous and include cobble-sized rip-up clasts of nannofossil ooze with clay, pebble-sized botryoidal concretions (Figure F14), and sand-sized grains of glauconite and quartz embedded in a matrix of biogenic silt and clay (measured carbonate content $=\sim 60 \mathrm{wt} \%$; Figure F8). Subunit IF sediment fines upward in grain size and is heavily bioturbated. The cores are slightly to moderately biscuited or fractured due to drilling disturbances.

The lower contact of Subunit IF, which is also the base of lithostratigraphic Unit I, is erosional and marked by the emplacement of a poorly sorted sandy layer (Figure F14). The lower Subunit IF boundary is also marked by distinct discontinuities in $P$-wave velocity, NGR, magnetic susceptibility, porosity, MAD, red-green-blue color space (RGB) colors, and blue color (reflectance $b^{*}$; see Igneous and metamorphic petrology in the Expedition 367/368 methods chapter [Sun et al., 2018a]) but does not represent a major gap in sediment age (all Oligocene; see Biostratigraphy). Measured carbonate contents markedly decrease from 56-66 wt\% in Subunit IF to $2-10 \mathrm{wt} \%$ in Subunit IIA.

\section{Unit II}

Intervals: $368-\mathrm{U} 1501 \mathrm{C}-45 \mathrm{X}-1,51 \mathrm{~cm}$, to $62 \mathrm{X}, 39 \mathrm{~cm}$; 368-U1501D-2R-1, $0 \mathrm{~cm}$, to 19R-2, $135 \mathrm{~cm}$

Depths: Hole U1501C $=303.01-458.09 \mathrm{~m}$ (base of Unit II not recovered); Hole U1501D = 433.5-598.91 m (top of Unit II not recovered)

Age: Oligocene to Eocene 
Figure F14. Contact between Units I and II (368-U1501C-45X-1, $50 \mathrm{~cm}$ ). Nannofossil ooze with clay dominates Subunit IF with centimeter-sized concretions at the lower boundary and rip-up clasts. Subunit IIA is dominated by nannofossil-rich clay. Photomicrographs show (top) nannofossil ooze with clay, (middle) concretions, and (bottom) nannofossil-rich clay.

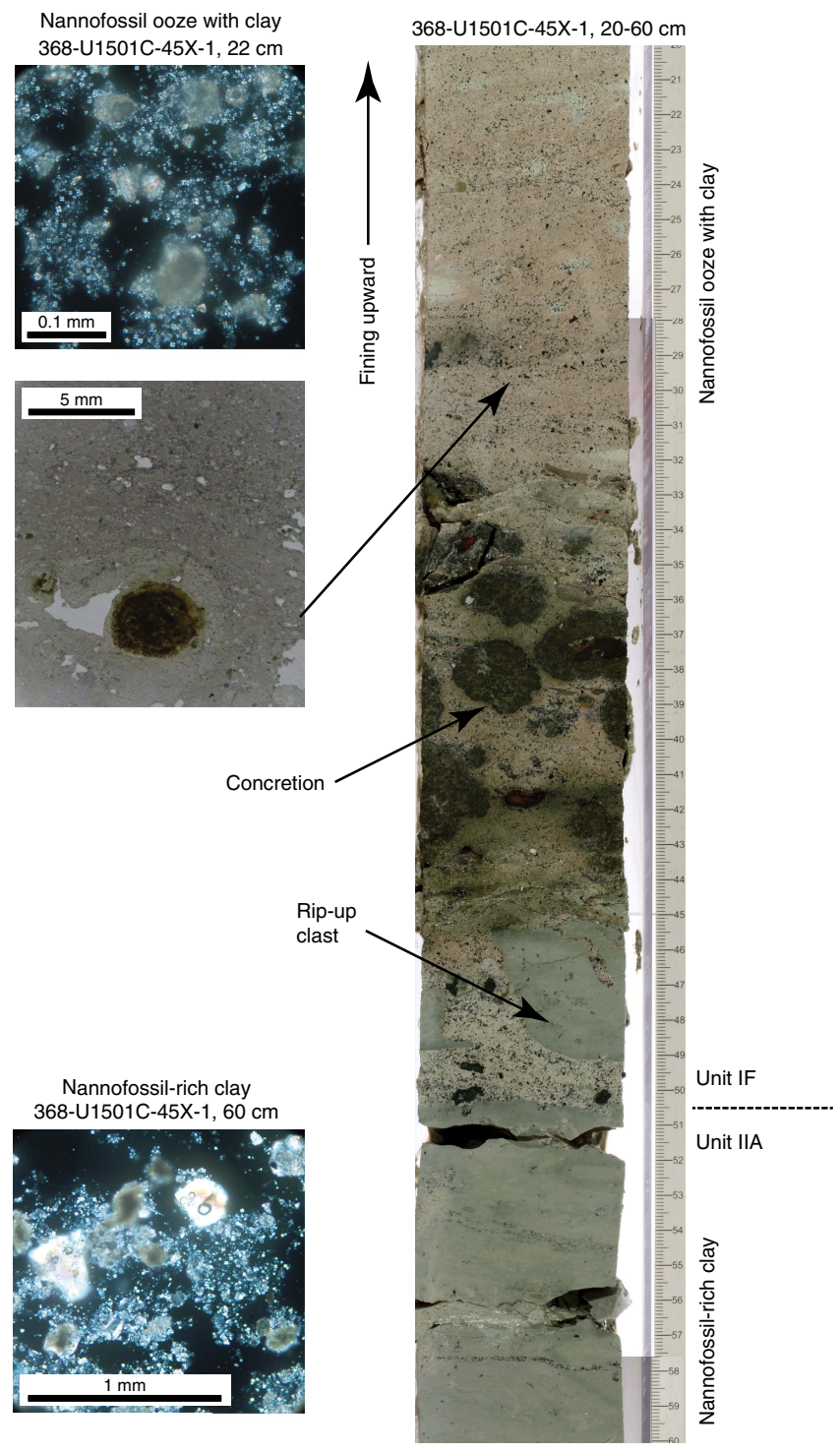

Lithology and sedimentary structures

Lithostratigraphic Unit II was recovered in Holes U1501C and U1501D. It consists of variable amounts of clay, silt, and sand (clay, silty clay, clayey silt, sandy silt, silty sand, and sand, which may be clay rich, with sand or with clay) with some nannofossil-rich clay (Figure F14), clay with nannofossils and minor nannofossil ooze, and clayey silt and silt with organic matter. In addition, gravel-sized grains include shell fragments and glauconite, as well as carbonate and pyrite concretions. The overall carbonate contents of Unit II is significantly lower (2-10 wt\%) than that of Unit I (12-66 wt\%) (Figure F8). Unit II is divided into six subunits (Figure F15) based on minor changes in lithology and grain size.

\section{Bulk mineralogy and chemistry}

The bulk mineralogy results of XRD analyses are listed in Table T2. Unit II sediments are composed mainly of glauconite, quartz, plagioclase, K-feldspar, clay minerals (including smectite, illite, and kaolinite), and minor amounts of pyrite and halite.

Figure $\mathbf{F} 8$ shows the downcore variations in the relative contents of minerals identified by XRD in bulk sediments at Site U1501. Compared to Unit I, Unit II has distinct higher percentages of authigenic glauconite and terrigenous minerals, including quartz, plagioclase, K-feldspar, and clay minerals (illite and kaolinite). Unit II sediments have lower contents of calcite, pyrite, chlorite, and smectite. Most of the terrigenous minerals (illite, kaolinite, K-feldspar, and plagioclase) increase downcore in Unit II. We can only trace the downcore trend of glauconite content, rather than its precise abundance, because of its very poor crystallinity (wide peak around 7$\left.8.9^{\circ} \Delta 2 \theta\right)$ at the study site and the lack of a shipboard standard for calibration.

Compositional analyses of the clay in Sections 368-U1501C$45 \mathrm{X}-1$ and $45 \mathrm{X}-2$ were made directly on the archive half of the core using the handheld pXRF instrument (see Igneous and metamorphic petrology in the Expedition 367/368 methods chapter [Sun et al., 2018a]). The pXRF data are shown in Table T3. The nine analyzed intervals show no significant trends downhole. The clay has $\mathrm{SiO}_{2}$ contents between 30 and $38 \mathrm{wt} \%, \mathrm{Al}_{2} \mathrm{O}_{3}$ contents between 8 and $11 \mathrm{wt} \%$, and low $\mathrm{CaO}$ contents $(<5 \mathrm{wt} \%)$. The intervals in Section 45X-2 have sulfur contents between 690 and 4600 ppm. Zr contents are constant at $\sim 70 \mathrm{ppm}$.

The uppermost two subunits of Unit II define a fining-upward succession from glauconite sand dominated in Sections 61X-CC through 59X-5 to siltstone and clay in Sections 59X-5 through 53X1 (Subunit IIB) and clay with nannofossils in Core 53X through Section $45 \mathrm{X}-1$ (Subunit IIA). Subunit IIC is dominated by sandstone with calcite but shows poor recovery. Subunit IID is distinctive with more fine grained, organic-rich lithologies. Subunit IIE is similar to Subunit IIC, whereas Subunit IIF repeats Subunit IIB but has more coarse-grained sediment and distinctive weak red and reddish gray intervals between the green glauconite-bearing sands.

The sediment in Unit II is matrix supported and moderately to poorly sorted. Coarse sand- to pebble-sized shell fragments are common. Coral fragments occur occasionally in the upper part of the unit. Glauconite and quartz minerals dominate the siliciclastic grain component. Diagenetic pyrite concretions, patches, or laminae are common throughout Unit II (Figure F16). Locally, carbonate and clay concretions are found. The measured carbonate content of Subunits IIA and IIB ranges from 2 to $10 \mathrm{wt} \%$ (Figure F8).

Horizontal lamination and ripple lamination can be recognized even though the entire interval is variably affected by drilling disturbance. Cross-bedding is present, as well as occasional fining-upward lamination, mostly in Subunit IIB. Bioturbation in Unit II is moderate. Burrows are horizontal to gently dipping and belong to the Zoophycos ichnofacies in Subunit IIA.

Drilling disturbance within Unit II varies from slight to high. Cores are slightly to heavily biscuited and partly fractured. Core 368-U1501C-62X has basal flow-in, and Cores 368-U1501D-2R, 8R, and $15 R$ have soupy intervals.

\section{Subunit IIA}

Interval: $368-\mathrm{U} 1501 \mathrm{C}-45 \mathrm{X}-1,51 \mathrm{~cm}$, to $53 \mathrm{X}-\mathrm{CC}, 26 \mathrm{~cm}$

Depth: 303.01-385.26 m

Age: Oligocene to late Eocene

Subunit IIA is characterized by an overall fining-upward sequence from sand with clay to nannofossil-rich clay and clay-rich 
Figure F15. Simplified lithology and unit description overview, Unit II.

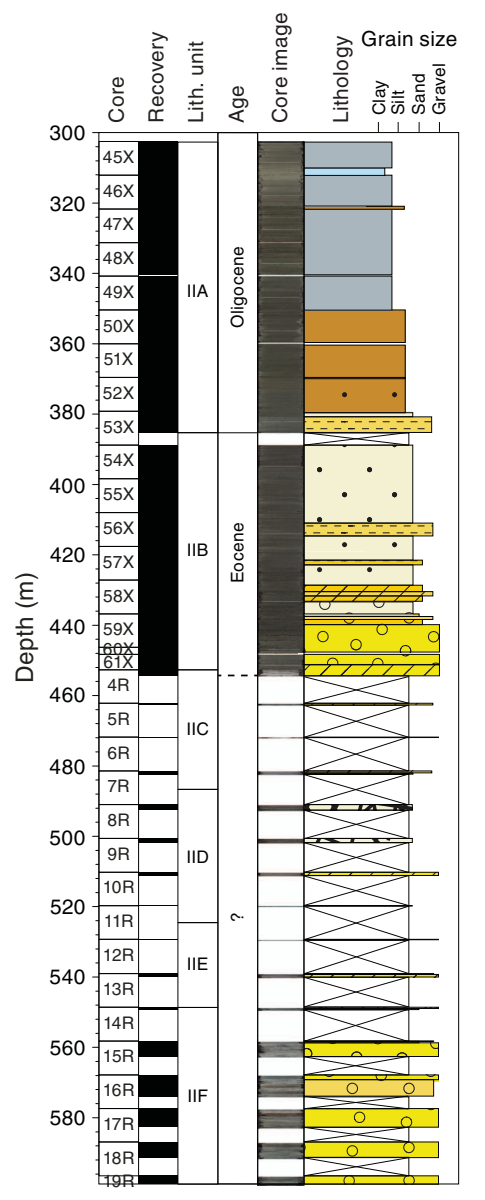

nannofossil ooze. The sediments are well consolidated and well sorted. Sections $45 \mathrm{X}-1,51 \mathrm{~cm}$, to $49 \mathrm{X}-\mathrm{CC}, 39 \mathrm{~cm}$, are composed of greenish gray to very dark greenish gray nannofossil clay and clayrich nannofossil ooze with a maximum grain size of silt to fine sand. Several intervals fine upward from coarse sand to clay (e.g., intervals $48 X-2,103-151 \mathrm{~cm}$, and 48X-3, 136-151 cm). Boundaries between sediment layers are horizontal and gradational. Very dark greenish gray silty clay with nannofossils was recovered from Section 50X-1, $0 \mathrm{~cm}$, to $51 \mathrm{X}-\mathrm{CC}, 34 \mathrm{~cm}$. This interval shows cross-bedding, lamination, and a maximum grain size of fine sand. Grain size changes to silty clay with sand in Sections $52 \mathrm{X}-1,0 \mathrm{~cm}$, to $52 \mathrm{X}-\mathrm{CC}, 45 \mathrm{~cm}$. From Section 53X-1, $0 \mathrm{~cm}$, to $53 \mathrm{X}-\mathrm{CC}, 26 \mathrm{~cm}$, the grain size increases from clayey silt with sand to silty sand and sand with clay (Figure F17). Boundaries between layers are gradational and horizontal, and lenticular bedding was observed in interval 53X-3A, $124-134 \mathrm{~cm}$. The sediment is greenish gray and rich in sand-sized glauconite and quartz crystals. Shell fragments as large as $1 \mathrm{~cm}$ and foraminifers are common. Pyrite patches a few centimeters in size (Figure F16) occur throughout Subunit IIA. Bioturbation is moderate in the lower part of Subunit IIA (Sections $53 \mathrm{X}-1,0 \mathrm{~cm}$, to $53 \mathrm{X}-$ CC, $26 \mathrm{~cm}$ ) and heavy in the upper part. The Subunit IIA/IIB boundary is characterized by a change in grain size. The recovered sediments are slightly to moderately disturbed with biscuits and fractures.

\section{Subunit IIB}

Intervals: $368-\mathrm{U} 1501 \mathrm{C}-54 \mathrm{X}-1,0 \mathrm{~cm}$, to $61 \mathrm{X}-\mathrm{CC}, 7 \mathrm{~cm}$; $368-\mathrm{U} 1501 \mathrm{D}-2 \mathrm{R}-1,0 \mathrm{~cm}$, to $3 \mathrm{R}-\mathrm{CC}, 40 \mathrm{~cm}$

Depths: Hole U1501C $=388.80-452.69 \mathrm{~m}$; U1501D $=433.5-$ $448.24 \mathrm{~m}$ (top of Subunit IIB not recovered)

Age: Eocene

Subunit IIB has well-consolidated sediment with fining-upward intervals that vary in grain size from clayey silt with sand to silty sand with clay to sand. The color changes from greenish gray (Core 368-U1501C-54X) to dark greenish gray (Sections 55X-1 through $57 \mathrm{X}-5$ ) to very dark greenish gray (Sections $57 \mathrm{X}-6$ through $58 \mathrm{X}$ $\mathrm{CC}$ ). The average grain size is silt to coarse sand, with a maximum grain size of granule and pebble. The sorting of the intervals in this subunit is moderate to poor.

Boundaries between sediment layers are gradational and horizontal, and layers fine upward (e.g., Section 59X-3). The sediment is rich in sand-sized glauconite and quartz crystals (Figure F17). There are pyrite patches throughout the subunit, especially in Sections 55X-1, 55X-2, 55X-5, 59X-3, 59X-5, 59X-6, and 60X-1 and in all sections of Core $61 X$. Shell fragments are common and horizontally oriented within the sediment (Figure F16). Calcite concretions occur in Section 58X-1, $42 \mathrm{~cm}$, and interval 58X-CC, $16-18 \mathrm{~cm}$. Bioturbation in Subunit IIB is moderate.

The Subunit IIB/IIC boundary is characterized by a change from glauconite-rich sand/sandstone to sandstone with calcite. 
Figure F16. Special features, Subunits IIA and IIB. A. Thin parallel laminations. B. Gastropod shell filled with pyrite. C. Calcite concretion. D. Pyrite nodule. E. Coral fragment.
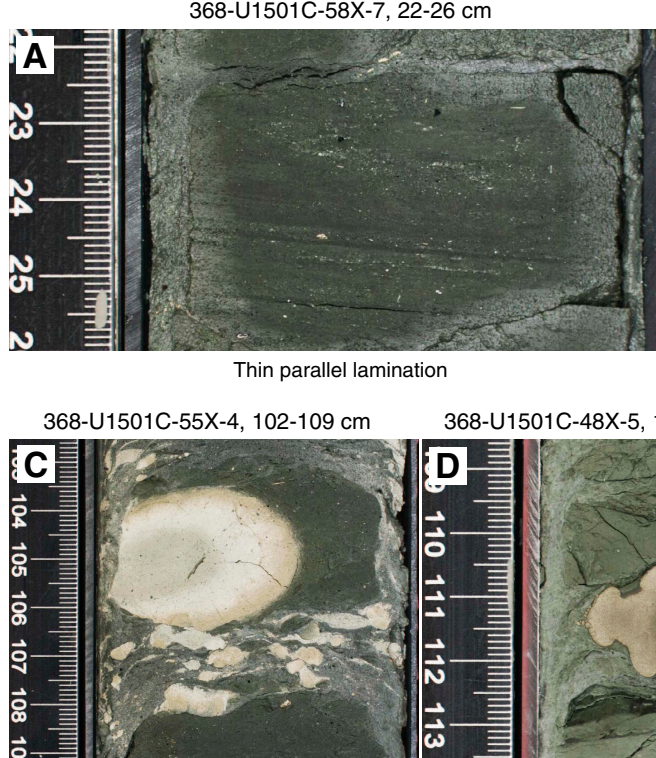

Calcite concretions
$368-U 1501 C-48 X-5,108-113 \mathrm{~cm}$

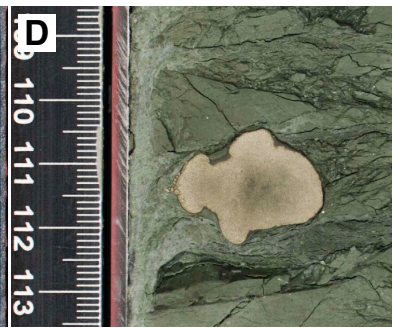

Pyrite nodule
368-U1501C-59X-4, 19-20 cm

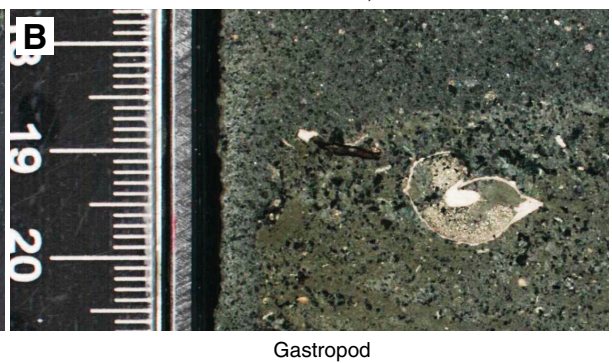

368-U1501C-58X-2, 60-62 cm

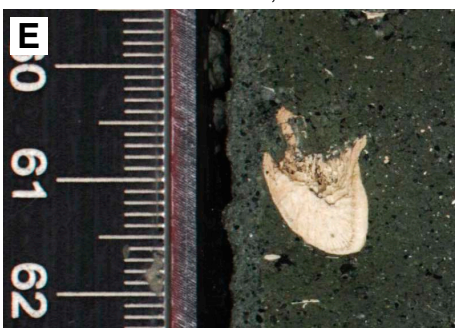

Coral fragment
NGR values decrease at the transition from Subunit IIB to IIC (see Physical properties). The sediment in Subunit IIB is biscuited due to drilling, with disturbance intensities from moderate to high.

\section{Subunit IIC}

Intervals: $368-\mathrm{U} 1501 \mathrm{C}-61 \mathrm{X}-\mathrm{CC}, 7 \mathrm{~cm}$, to $62 \mathrm{X}-\mathrm{CC}, 39 \mathrm{~cm}$; 368-U1501D-4R-1, $0 \mathrm{~cm}$, to 7R-1, $93 \mathrm{~cm}$

Depths: Hole U1501C $=452.69-458.09$ m (base of subunit IIC not recovered); Hole U1501D = 452.60-482.33 m

Age: Eocene

Subunit IIC is composed of gray sandstone with calcite, silty sandstone with calcite, and minor gray clayey silt with organic matter (Figure F18). The average grain size is coarse sand with a maximum of granule and pebble sizes, and the sediment is well to moderately sorted. Boundaries between sediment layers are planar and horizontal or erosive and curved. Recovery was very low $(<10 \%)$ in this subunit (Figure F7). Shell fragments are abundant, and pyrite patches and calcite veins occur. The lithified sandstone is slightly bioturbated.

Drilling disturbance is moderate to high throughout Cores 368U1501C-61X through 62X. The sediment is biscuited, fractured, and brecciated. Soft sediment recovered in Core $62 \mathrm{X}$ is interpreted as fall-in and basal flow-in and is therefore not described in any detail.

The boundary between Subunits IIC and IID is marked by a distinctive change from calcite-rich sandstone to more fine grained clay and organic-rich lithologies in Subunit IID.

\section{Subunit IID}

Interval: 368-U1501D-8R-1, $0 \mathrm{~cm}$, to $11 \mathrm{R}-\mathrm{CC}, 10 \mathrm{~cm}$

Depth: 491.00-519.80 m

Age: Eocene

Subunit IID is composed of alternating laminae of dark gray to very dark gray clayey silt with organic matter or lignite (Figure F19).
Figure F17. Glauconite sand, Unit II. A. Glauconite-rich sand, Subunit IIA. Rounded green glauconite grains in smear slide image. B. Glauconite-rich sand, Subunit IIB. Thin section is dominated by quartz and glauconite grains.

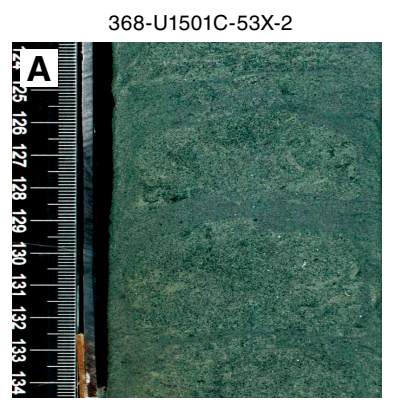

368-U1501C-61X-3

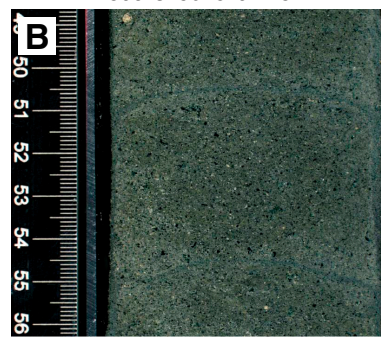

368-U1501C-53X-2, $130 \mathrm{~cm}$

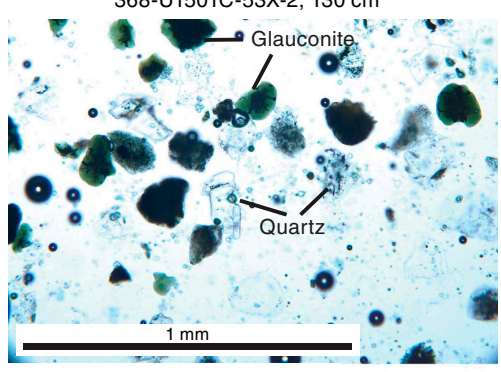

368-U1501C-61X-CC, $26 \mathrm{~cm}$

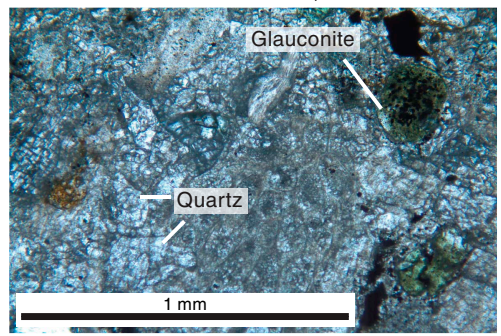

The sediment is slightly consolidated with an average grain size of silt and a maximum grain size of medium sand. The sediment is well to moderately sorted and characterized by very fine laminations and minor pebble-sized wood fragments. The organic matter occurs in clasts, lenses, or laminae. There is no bioturbation. The sediment is slightly soupy. Sandstone layers, similar to those described in Subunit IIC, are intercalated with the clayey silt.

Similar to Subunit IIC, recovery in this unit is also very low $(<10 \%)$. The boundary between Subunits IID and IIE is characterized by a lack of organic-rich layers and a change to calcite-rich sandstone in Subunit IIE. 
Figure F18. A. Calcite-rich sandstone with calcite-filled veins, Subunits IIC and IIE. B. Close-up image (red square in A) of calcite veins. C. Smear slide image of sandstone that is dominated by quartz crystals and calcite matrix.

A 368-U1501D-13R-1
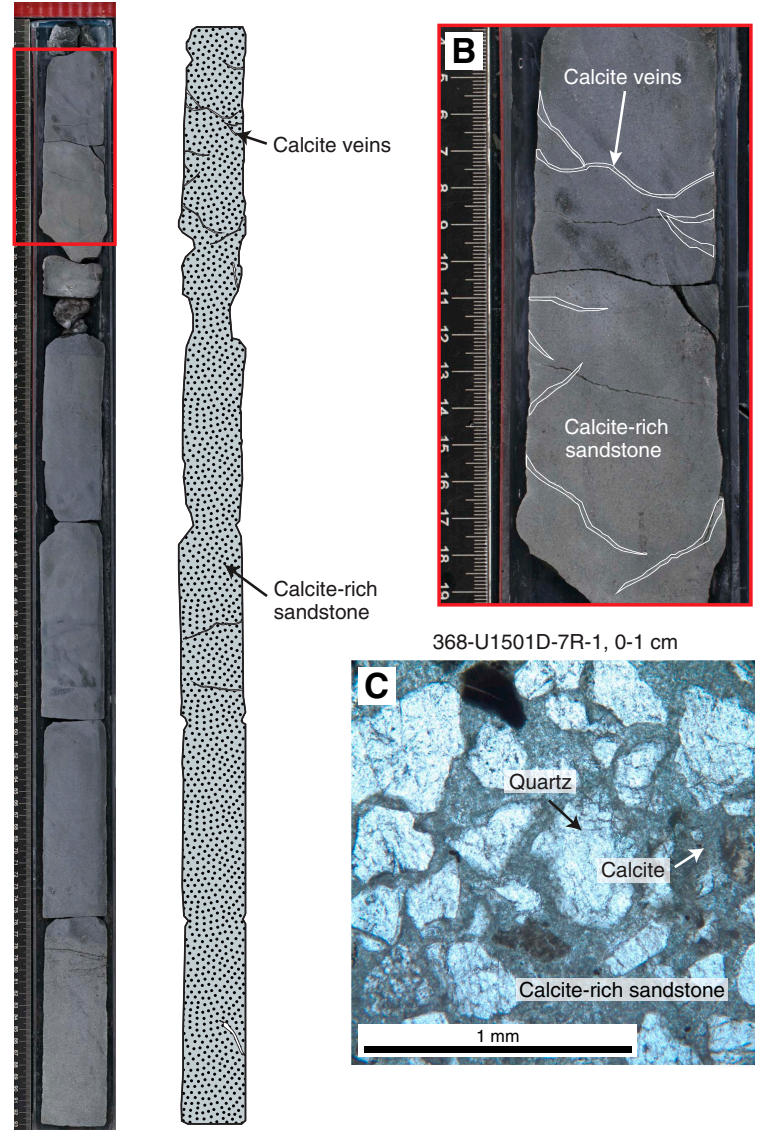

368-U1501D-7R-1, 0-1 cm

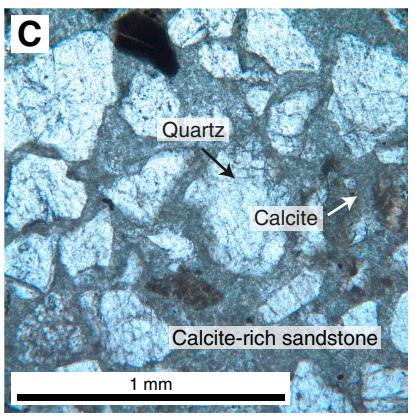

Subunit IIE

Interval: $368-\mathrm{U} 1501 \mathrm{D}-12 \mathrm{R}-\mathrm{CC}, 0 \mathrm{~cm}$, to $14 \mathrm{R}-1,4 \mathrm{~cm}$

Depth: 529.30-548.64 m

Age: Eocene

Subunit IIE is composed of gray silty sand with calcite, silty sandstone with calcite, and sandstone with calcite. The sediment is well consolidated to lithified, and the average grain size is fine to medium sand. The sediment is well sorted. Bioturbation is slight to moderate. The sediment is slightly fragmented due to drilling. This subunit appears similar to Subunit IIC (Figure F18).

Recovery in this subunit is extremely low $(<6 \%)$. Subunit IIE is similar to Subunit IIC, whereas Subunit IIF repeats Subunit IIB. The boundary between Subunits IIE and IIF is marked by a change from sandstone with calcite to gray and dark greenish gray glauconitebearing silty sand and silty sandstone.

\section{Subunit IIF}

Interval: 368-U1501D-14R-1, $4 \mathrm{~cm}$, to $19 \mathrm{R}-2,135 \mathrm{~cm}$

Depth: 548.64-598.91 m

Age: Eocene

Subunit IIF is composed of gray, dark greenish gray, greenish gray silty sand, sandy silt and sand, and silty sandstone, as well as weak red silty sand and silty sandstone. A color change to weak red is observed in Sections $17 \mathrm{R}-1,101 \mathrm{~cm}$, to $17 \mathrm{R}-2,47 \mathrm{~cm}$. The consol-
Figure F19. A. Subunit IID is characterized by the presence of thin layers of organic matter within a clayey silt. Red square $=$ location of B. B, C. Close-up images of organic-rich layers and bedding structures. Layers of organic-rich material are intercalated with clayey silt layers. D. $5 \mathrm{~cm}$ of lignite-rich silt.

A 368-U1501D-8R-1, 0-106 cm
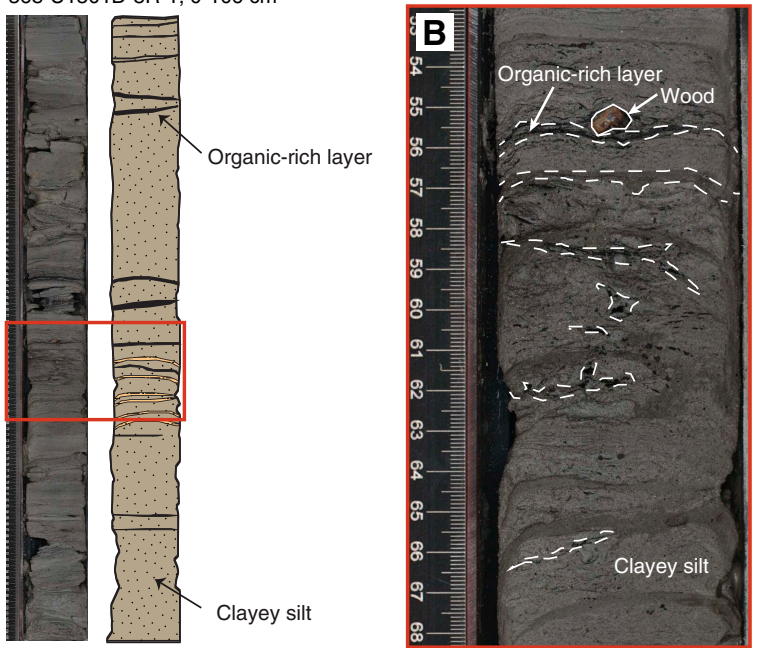

368-U1501D-8R-1, 44-50 cm

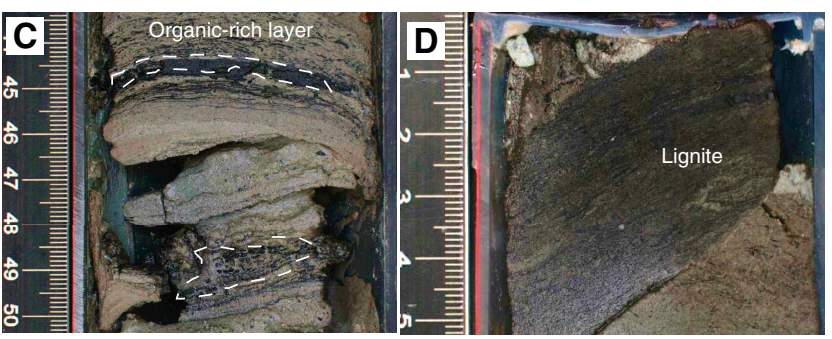

idation varies from well consolidated to lithified. The average grain size is from fine to coarse sand to a maximum of granule, and the sediment is well to moderately sorted. The bedding thickness is medium to thick (see Lithostratigraphy in the Expedition 367/368 methods chapter [Sun et al., 2018a]), and contacts between the beds are planar to gradational and horizontal to curved. The majority of the beds fine upward or are massive (Figure F20). The sands are rich in glauconite and quartz minerals. Pyrite is common, and patches are as large as centimeter sized (e.g., interval 16R-2, 77-129 cm). The sediment and lithified sandstone are slightly to moderately bioturbated. The sandstone is slightly fractured due to drilling disturbance. The contact with Unit III was not recovered, but Subunit IIF has marked brown- to ochre-colored alteration patches at the base (Figure F21).

\section{Unit III}

Interval: $368-\mathrm{U} 1501 \mathrm{D}-19 \mathrm{R}-3,0 \mathrm{~cm}$, to $27 \mathrm{R}-4,71 \mathrm{~cm}$

Depth: 598.91-643.56 m

Age: pre-Eocene

\section{Lithology and sedimentary structures}

Unit III was only recovered in Hole U1501D and consists of lithified sandstone, sandstone with gravel, and minor conglomerate and laminated siltstone. Unit III is divided into two subunits (Figure F22). Pebble- to cobble-sized clasts include felsic volcanic and plutonic rocks, sedimentary rocks, metamorphic rocks, and rare gabbro (Figure F23). 
Figure F20. A. Glauconite-rich coarse sandstone, Subunit IIF. The interval fines upward from very coarse sand to medium sand. B. Thin section image of glauconite sandstone dominated by quartz and glauconite. C. Glauconite-rich sandstone with burrows and blotches.

\section{Unit IIF}

\section{8-U1501D-16R-2, 55-76 cm}
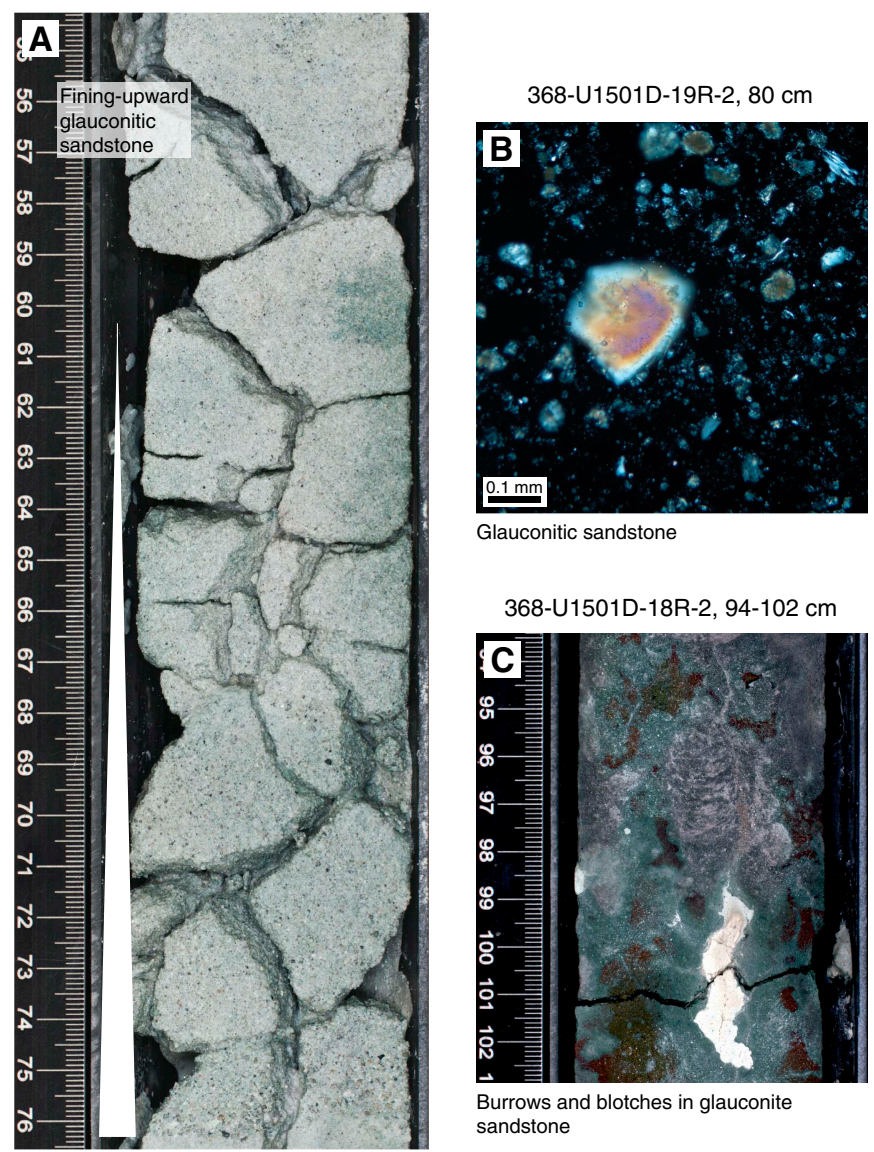

Glauconitic sandstone

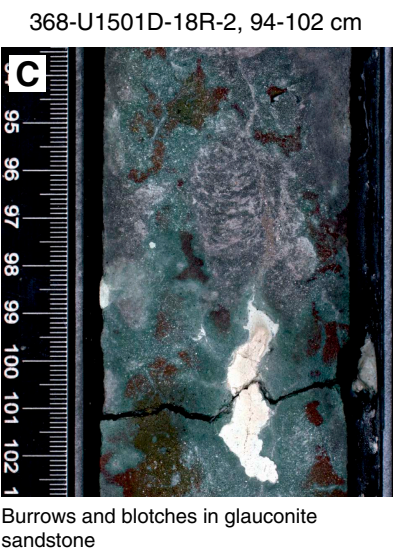

The contact between Units II and III was not recovered. The base of Section 19R-2 represents Unit II, and the top of Section 19R3 is in Unit III (Figure F21). However, the low recovery (26\%) indicates that intervals are missing. The boundary is marked by an abrupt downhole increase in magnetic susceptibility, NGR, and Pwave velocity, so it is assumed that this boundary is sharp. A change in the apparent dip of strata from approximately horizontal (seismics show $\sim 5^{\circ}$ ) in Unit II to $\sim 20^{\circ}$ in Unit III (see Structural geology) suggests that the contact is unconformable.

\section{Bulk mineralogy}

The bulk mineralogy results of XRD analyses are given in Table T2 and Figure F8. Unit III sediments are composed mainly of quartz, plagioclase, and K-feldspar, as well as minor amounts of kaolinite and mica. Compared to Units I and II, Unit III sediments have much higher K-feldspar and plagioclase abundances but almost no calcite, glauconite, or pyrite.

\section{Subunit IIIA}

Interval: $368-\mathrm{U} 1501 \mathrm{D}-19 \mathrm{R}-3,0 \mathrm{~cm}$, to $25 \mathrm{R}-1,9 \mathrm{~cm}$

Depth: 598.91-629.79 m

Age: pre-Eocene
Figure F21. Composite of core section images showing the lithologic change from greenish gray medium coarse sand with glauconite in Subunit IIF to gray lithified coarse sandstone in Subunit IIIA, Hole U1501D. Lower part of Subunit IIF (19R-2) shows irregular brown to ochre and purple patches inferred to be related to diagenetic alteration.

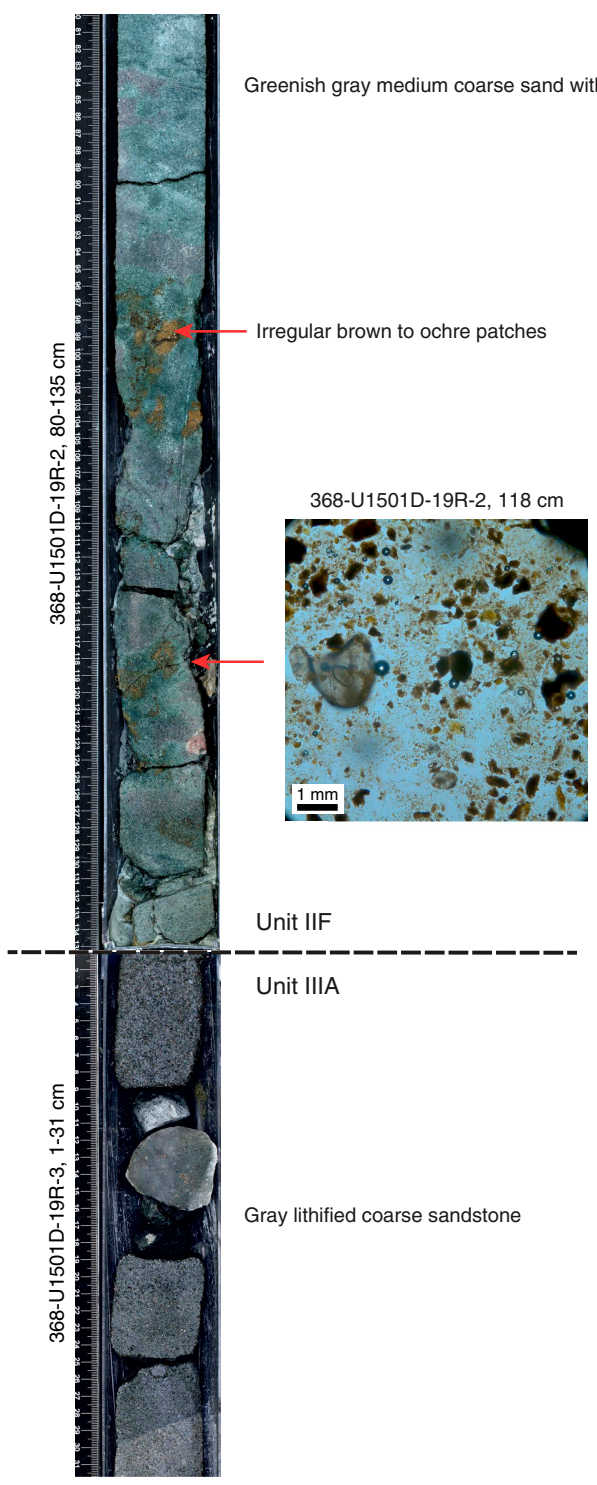

Subunit IIIA is composed of light gray to gray lithified sandstone, sandstone with gravel, and sandstone with calcite clasts (Figure F24), along with minor conglomerate and siltstone. The average grain size is medium to very coarse sand, and the maximum grain size is as large as cobble sized. The sorting is well to moderate, but some intervals are poorly sorted because of large pebbles or cobbles. The pebble- to cobble-sized clasts consist of felsic volcanic and plutonic rocks (granite), sedimentary rocks, and rare gabbro. The bottom contacts of beds are planar, erosional, gradational, and horizontal. The sandstone layers are massive or fine upward. Interval 22R-3, 80-102 cm, contains an $\sim 22 \mathrm{~cm}$ thick interval of dark gray siltstone. The contact with the overlying sandstone was not recovered, but the bottom contact with the underlying conglomerate is erosive and inclined. Intervals 22R-3, 102-105 cm, and 22R-CC, 0$19 \mathrm{~cm}$, are composed of poorly sorted conglomerate. 
This subunit consists of heterolithic, densely packed, moderately sorted siltstone to coarse-grained heterolithic sandstone rich in quartz, feldspar, and sedimentary lithoclasts (mudstone) (Figure F24). The grains are cemented with a mixture of clay and calcite. There are minor amounts of mica, amphibole, and opaque minerals, as well as traces of glauconite pellets. Igneous (volcanic and plutonic) and metamorphic lithoclasts (quartzite) are rare. Alteration is pervasive, and most feldspar grains have been pseudomorphed by clay minerals. A cobble of slightly recrystallized granite was recovered in interval 19R-3, 13-28 cm, and is composed of quartz, feldspar, mica, and amphibole with traces of apatite and zircon.

A distinctive thick bed of dark brown clay-rich silty sandstone and clay-rich silty sandstone with gravel occurs in Sections 23R-2 (Figure F24) and 23R-3. This bed has a massive base and grades into gray silty sandstone with gravel in Section 23R-4. The fine-grained upper interval of the bed is poorly sorted with millimeter-sized feldspar grains in a fine-grained red clayey matrix.

The transition to Subunit IIIB is sharp and marked by a change from sandstone and sandstone with gravel to sandstone and sandstone with silt. Magnetic susceptibility decreases toward the base of Subunit IIIA.

Figure F22. Simplified lithology and unit description overview, Unit III.

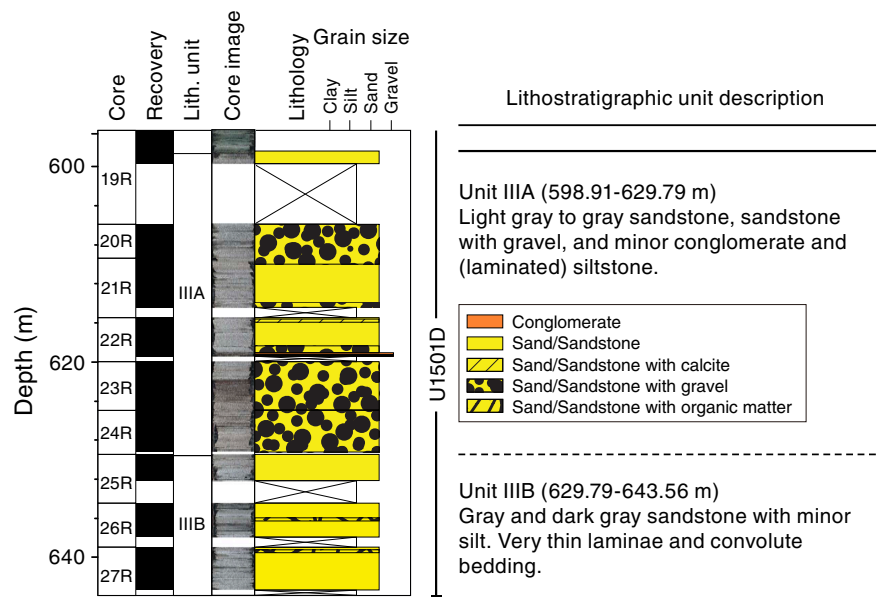

\section{Subunit IIIB}

Interval: $368-\mathrm{U} 1501 \mathrm{D}-25 \mathrm{R}-1,9 \mathrm{~cm}$, to $27 \mathrm{R}-4,71 \mathrm{~cm}$

Depth: 629.79-643.56 m

Age: pre-Eocene

Subunit IIIB consists of light gray, gray, and minor dark gray sandstone, sandstone with silt, and minor sandstone with organic matter (Figure F24). This subunit is different from Subunit IIIA in that it is finer grained overall and has finely laminated intervals. The average grain size is fine to very coarse sand, and the maximum grain size is as large as pebble sized. The sediment is very well to moderately sorted, but some intervals are poorly sorted because of pebbles. The pebble-sized clasts consist of felsic volcanic rocks and fine-grained quartzite. The bottom contacts of the beds are planar to erosional to gradational and subhorizontal to horizontal. The sandstone layers are massive or fine upward.

Interval 26R-3, 7-54 cm, has convolute lamination intercalated between planar laminated intervals that is interpreted as soft-sediment deformation. Some intervals of fine sandstone and siltstone have plane and ripple cross-lamination. However, most beds are fairly massive or show weak grading. A bituminous clast was recovered in Section 27R-1 (Figure F24).

\section{Discussion \\ Depositional environment of Unit III}

Unit III consists of poorly sorted, feldspar-rich, coarse-grained sandstone with pebbles or cobbles that is interbedded with light gray and gray to dark gray moderately to well-sorted medium- to fine-grained sandstone and rarely siltstone and poorly sorted conglomerate. Both massive bedding and fining-upward grading is common in the coarse-grained sandstone and conglomerate, whereas the relatively well sorted medium- to fine-grained sandstone intervals have thin parallel bedding. Finely rippled cross-lamination, convolute bedding, pyrite patches, and organic-rich laminae and lenses were found in the fine-grained interbeds. In addition, glauconite particles occur in some thin sections. No fossils were found. In general, we speculate that Unit III was formed in a terrestrial to littoral environment with a provenance not far from the site (Figure F25). The well-sorted sandstone with parallel to low-angle cross-lamination could have been formed by wave re-

Figure F23. A-D. Diverse lithologies of pebble- to cobble-sized clasts in Unit III sandstone.
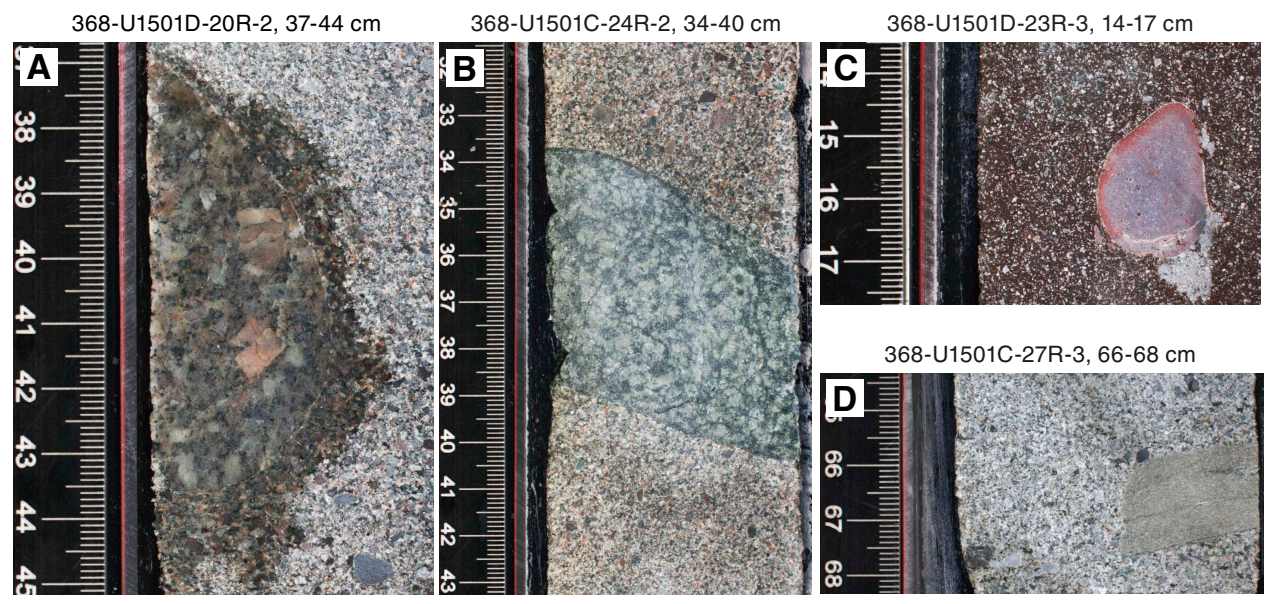

368-U1501C-27R-3, 66-68 cm

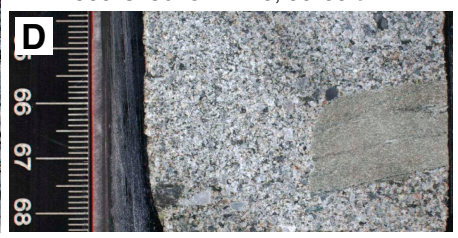


Figure F24. Sandstone, Unit III. A. Subunit IIIA is dominated by gray coarsegrained sandstone rich in feldspar. B. Thin section image of heterolithic feldspar-rich sandstone showing rounded sedimentary, volcanic, and metamorphic (mica-bearing quartzite) lithic grains. Subunit IIIB is dominated by gray sandstone with $(C)$ very thin laminae, $(D)$ calcite clasts, and $(E)$ bituminous clasts.
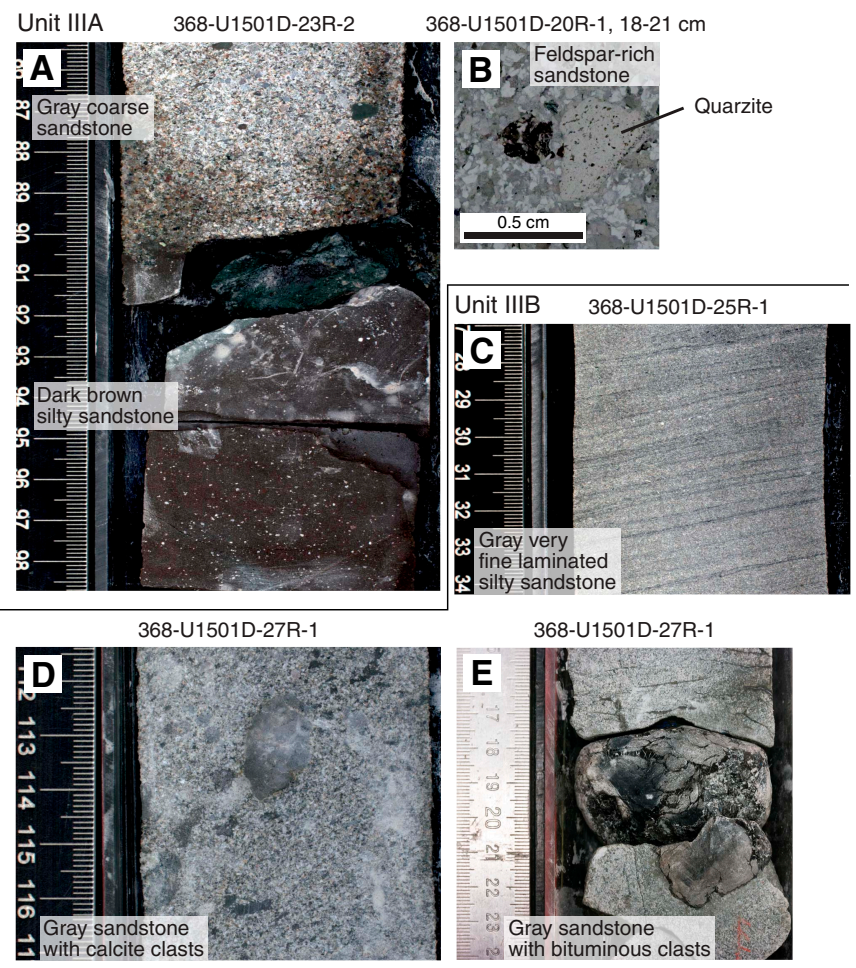

368-U1501D-27R-1

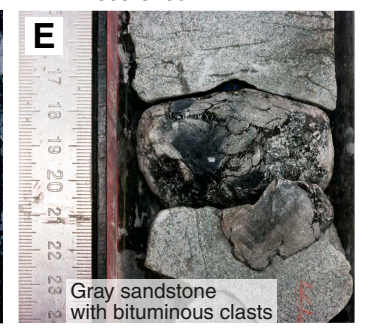

working in a littoral environment. Overall, the downhole color change from more or less brownish to grayish rock and the decrease in average grain size may indicate a change to a deeper water environment.

\section{Transition between Units II and III}

The boundary between Units II and III is in Core 368-U1501D$19 \mathrm{R}$ at around $598.91 \mathrm{~m}$. The boundary separates the overlying greenish to dark greenish and less consolidated glauconite-bearing silty sand/sandstone of Unit II from the underlying dark brownish to gray and well-lithified sandstone with minor conglomerate and siltstone interbeds. The Unit II/III boundary is marked by an abrupt change in magnetic susceptibility, NGR, and $P$-wave velocity. In the seismic data, the boundary is tied to the acoustic basement $(\mathrm{Tg})$, a high-amplitude reflector separating the overlying high-amplitude reflections in Unit II from the underlying low-amplitude reflections in Unit III (see Background and objectives).

We speculate if the Tg reflector between Units II and III might represent a boundary between possible early synrift (Paleocene?) deposits and the Eocene synrift sediments of Unit II or simply a hiatus between the Eocene synrift deposits of Unit II and a pre-Cenozoic basement (Unit III) (Shi et al., 2014; Dai et al., 2015). In the first case, Unit III could be similar to the Paleocene nonmarine sandstone and conglomerate successions common in the petroleumbearing basins of eastern China. However, we found glauconite particles in the Unit III sandstone, which is commonly an indicator of marine environments (McRae, 1972; Wigley and Compton, 2007; Harris and Whiting, 2000). Most importantly, the sandstone in Unit
Figure F25. Preliminary model for deposition and sedimentary environments at Site U1501 showing deposition of prerift sediment and formation of the different units during and after rifting of the SCS.

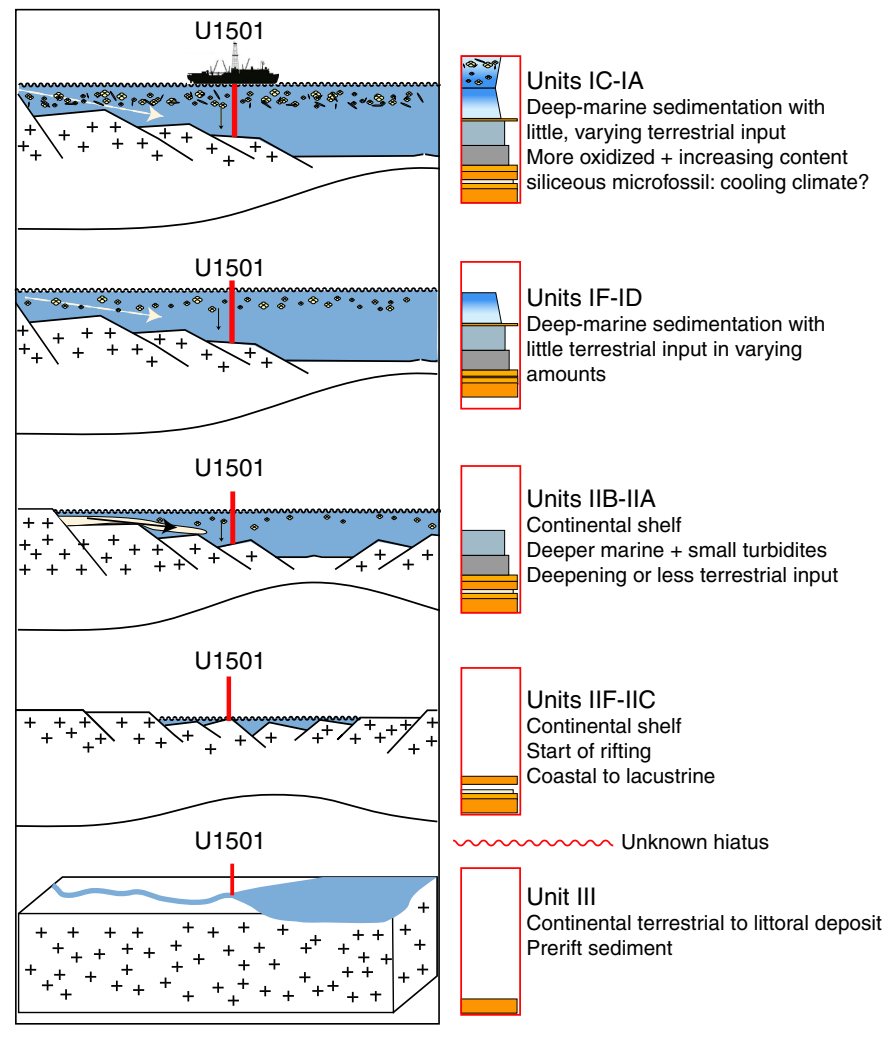

III is quite different from the overlying sand/sandstone in Unit II in terms of color, composition of clastic components, degree of lithification, and physical properties, including seismic velocity (see Physical properties). Therefore, we suggest the transition from Unit II to III represents a significant hiatus that formed in late Mesozoic to perhaps early Cenozoic time and that the sand-dominated terrigenous clastic rocks of Unit III represent a pre-Cenozoic basement succession. Regional geologic research (e.g., Yao et al., 1994; Zhou et al., 1995, 2006) indicates that in the late Mesozoic there was an active continental margin in eastern Asia, including the northern SCS margin, where the paleo-Pacific Ocean plate was subducted under the Eurasia plate. Therefore, the Unit II/III boundary could represent the transition from an active margin to a passive margin setting. Obviously, postexpedition research is needed to further constrain the age and nature of the boundary between Units II and III.

\section{Depositional environment of Unit II}

Unit II most likely represents a gradual change from shallowwater (outer shelf or upper continental slope) to deepwater (lower slope) depositional environments (Figure F25). In general, the sediments of the lower part, including Subunits IIB-IIF, are dominated by terrigenous materials (quartz and clay minerals) and/or authigenic minerals (glauconite and calcite), with very rare calcareous nannofossils or foraminifer tests. Moreover, the glauconite (Figure F17) and large shell fragments become more common downhole and are even abundant in these subunits.

Glauconite is a clay- or mica-like mineral that usually forms from the absorption of potassium and iron by a degraded-layer sili- 
cate lattice. Glauconite formation appears related to organic activity because grains are often found with decaying organic matter or the tests of marine organisms (McRae, 1972). Glauconite grains may form as clasts or fecal pellets or by accretionary growth, leading to a wide range of external morphologies (McRae, 1972). Glauconite clasts in Unit II have a range of morphologies from angular to well rounded and equant to more elongate. Some well-rounded glauconite grains occur mixed with subangular terrigenous quartz grains (Figure F17), suggesting that the rounded morphology is not a result of reworking but due to their formation as fecal pellets.

Modern deposits typically occur at low latitudes (temperatures ranging from $7^{\circ}$ to $15^{\circ} \mathrm{C}$ ) (Margielewski et al., 2017) and where there are low oxygen contents, mostly in the shelf to lower-slope environments from 20 to 700 mbsl (e.g., Drzewiecki and Simó, 2002; Margielewski et al., 2017) but also (less common) in anoxic and salty lake or marginal sea environments such as the Black Sea (Suttill, 2009). Glauconite forms where sedimentation rates are low and the formation can be stopped by rapid sedimentation. Glauconite grains are often associated with marine transgressions, unconformities, condensed sections, or transgressive systems tracts (McRae, 1972; Wigley and Compton, 2007; Harris and Whiting, 2000). However, because glauconite can form in a wide range of environments, it may not be a good tool for use in paleoenvironmental studies (McRae, 1972). Margielewski et al. (2017) found that glauconite grains are not destroyed when transported for short distances but break down to become part of the finer sediment fraction in highenergy environments. Glauconite grains could therefore be found in redeposited sediment sequences but only if mechanical abrasion and chemical destruction is limited.

A remarkably similar Tertiary sequence was described by Exon et al. (2002) for sites drilled during ODP Leg 189 offshore Tasmania. The glauconite-bearing silty claystone and clayey siltstone was deposited very slowly, representing a condensed sequence with sedimentation rates of $<1 \mathrm{~cm} / \mathrm{ky}$. The comparable sediment at Site U1501 was deposited at an approximate rate of $2.5-3 \mathrm{~cm} / \mathrm{ky}$ based on a preliminary shipboard age/depth curve. This rate is much greater than expected for a sediment-starved glauconite sand shelf and supports redeposition of the glauconite-bearing silts and sands in Subunits IIA, IIB, and IIF.

Subunit IID, between the calcite-rich sandstones of Subunits IIC and IIE, is different than other parts of Unit II and is characterized by alternating laminae of dark gray clayey silt with organic matter or lignite. The lack of marine fossils and authigenic glauconite and the frequent thin organic-rich laminae with pyrite and very fine grained clayey silt sediment likely indicate a very low sedimentation rate and a reducing, coastal brackish environment. A similar depositional environment was observed in a petroleum well of the eastern Pearl River Mouth Basin (Shao et al., 2016). Therefore, this unit may represent a temporary switch from shallow-marine environment to brackish facies.

The upper section of Unit II fines upward from sandy, silty, and clayey sediment in Subunit IIB to clayey sediment in Subunit IIA. This trend is accompanied by an upward increase in bioturbation intensity. The occurrence of a Zoophycos trace fossil assemblage in Subunit IIA indicates a moderate- to deepwater environment. We propose that this gradual transition is the result of a deepening of the basin. Benthic foraminifers from Subunit IIA suggest water depths of 300-800 m.

The coexistence of deepwater nannofossils and shallow-water shell and coral clasts suggests that the sediment was deposited by resedimentation processes. This idea is supported by the matrix- supported texture of the sediment and structures such as fining-upward strata and cross-bedding. These features indicate that the sediment may have been deposited by turbidity currents (Figure F20). We interpret the sediment intervals with horizontal and ripple laminations in Unit II as representing the $\mathrm{Tc}$ and $\mathrm{Td}$ divisions of a Bouma sequence.

\section{Transition between Units I and II}

The boundary between Units I and II is located at Section 368U1501C-45X-1, $51 \mathrm{~cm}$, and corresponds to a high-amplitude seismic unconformity. The boundary is dated at 24-27 Ma by the shipboard paleontologists based on foraminifer and nannofossil assemblages. We suggest this boundary can be correlated with the T60 unconformity at ODP Site 1148 (Li et al., 2005) (Figure F5). Above the boundary, Unit I is dominated by carbonate sediment, whereas Unit II is dominated by terrigenous material. The color of the sediment also varies abruptly from light brown in Unit I to dark and very dark greenish gray in Unit II.

\section{Depositional environment of Unit I}

Unit I was deposited in a deep-marine environment (Figure F25). The dominant lithologies are clay-rich nannofossil ooze and nannofossil ooze with clay. There are variable amounts of foraminifers. Lithologic changes between subunits likely reflect the amount of terrigenous input into a relatively open ocean setting. This input may be delivered as buoyant plumes from shallower shelf environments and rarely by weak (distal) turbidity currents. There is little change in the composition of the terrigenous grains, so we envisage a similar source for these grains throughout Unit I. Thin laminae of silt are found rarely but throughout Unit I. Some are graded, and all have sharp bases; however, many are disrupted by bioturbation and are interpreted as distal turbidites.

Soft-sediment deformation in Subunit IB, including inclined and convolute bedding, indicates slumping downslope of parts of the sequence. Bedding above and below this interval is consistently horizontal, indicating the deformation was synsedimentary.

\section{Structural geology}

Site U1501 is located on the OMH in a water depth of $2846 \mathrm{~m}$. The southwest-northeast-oriented seismic profile (Figure F5) across the $\mathrm{OMH}$ reveals the occurrence of extensional structures controlled by steeply dipping southwest-normal faults with obvious offset and tilting of seismic reflectors $\left(\sim 5^{\circ}\right)$. The T60 seismic unconformity is supposed to represent the Oligocene/Miocene boundary. Downsection, the Tg reflector may mark the base of the Cenozoic sediments (Pang et al., 2007). This site was considered a high-priority target to recover pre- (below Tg), syn-, and postrift sediments (see also Background and objectives).

\section{Lithostratigraphic Unit I structures}

Lithostratigraphic Unit I, which essentially consists of nannofossil oozes, has predominantly horizontal to subhorizontal bedding that in most cases is erased due to moderate to strong bioturbation. This unit is devoid of any structures related to tectonic deformation, apart from some rare normal faults, such as the one observed in interval 368-U1501C-19F-1, 109-127 cm (Figure F26), which preserves a high-angle planar normal fault with an apparent dip of $65^{\circ}$ and an offset of $6 \mathrm{~cm}$. In addition, local soft-sediment deformation structures such as slump folds were observed in Subunits IB and IC. 


\section{Lithostratigraphic Unit II structures}

Lithostratigraphic Unit II is characterized by subhorizontal to gently dipping bedding. Dips as steep as $40^{\circ}$ were locally observed in close relation to parallel lamination and therefore interpreted as cross-laminae (see Lithostratigraphy). In contrast to Unit I, deformation structures were observed within Unit II, although their occurrence is rather heterogeneously distributed. Subunit IIA is affected by millimeter-scale normal faults and joints, especially across Cores 368-U1501C-47X and 48X (Figure F27). In these cores, normal faults are typically planar to irregular with small apparent offsets as large as $0.5 \mathrm{~cm}$ and apparent dips of $10^{\circ}-40^{\circ}$. They form semiregular arrays with millimeter- to centimeter-scale spacing, often arranged in an "en echelon" geometry (e.g., interval 47X$6,126-129 \mathrm{~cm})$. Striations and slickensides were observed locally where the surfaces of such structures are exposed. The occurrence of slickensides and the overall polished appearance of such planes are clear evidence for a natural deformation process. However, the recognition of these original deformation structures remains locally difficult due to drilling disturbances caused by the XCB and RCB coring systems. Deformation in the underlying Subunits IIC-IIF is essentially characterized by the variably distributed occurrence of single to branched uniform calcite and quartz veins (Figure F28).

\section{Lithostratigraphic Unit III structures}

The prominent Tg reflector marks the top of lithostratigraphic Unit III, which is composed of lithified sandstone, sandstone with gravel, and minor conglomerate and laminated siltstone. This unit shows weak tilting of stratified beds expressed in apparent dips on split core surfaces as shallow as approximately $20^{\circ}$, which are best observed in the two last cores (368-U1501D-26R and 27R). Again, deformation structures remain scarce and heterogeneously distributed in Unit III. The recognized structures consist of veins, fractures, and local microfaults associated with cataclastic fault gouge. Locally structures associated with soft-sediment deformation are preserved. Single, branched, and en echelon uniform veins are filled by calcite or quartz (e.g., Cores 25R and 27R) (Figure F29). Planar and straight fractures were also observed with various dips from $40^{\circ}$ to $55^{\circ}$ showing locally striations and slickensides. In the sandstones, these fractures are often associated with alteration zones and filled by green fine-grained minerals likely resulting from diffusion-controlled chemical reactions between the matrix and a migrating reducing fluid (Figure F29A, F29D). Finally, slump folds were recovered in Core 26R (Figure F29F), providing evidence for softsediment deformation during mass movements.

\section{Interpretation}

Despite the various tilting of seismic reflectors in the proximity of extensional structures, especially between the T60 seismic unconformity and the Tg reflector observed on the seismic profile (Figure F5), no evidence of significant bedding tilting and/or deformation structures was observed at this site. However, the observed millimeter-scale normal faults in Unit II may be related to an extensional event during or soon after its deposition. In seismic data, the top of Unit II describes a wedge geometry controlled by southwestdipping normal faults (Figure F5). The end of this extensional event may correspond to the marked decrease of terrigenous input and the transition from clays, silts, and sands in Unit II to clearly pelagic nannofossil oozes in Unit I. In line with lithostratigraphic observations and physical properties, the boundary between Units I and II is extremely sharp, reflecting a switch from bathyal marine depo-
Figure F26. Deformation structures, Unit I. Normal fault affecting nannofossil oozes (368-U1501C-19F-1, 108-127 cm).

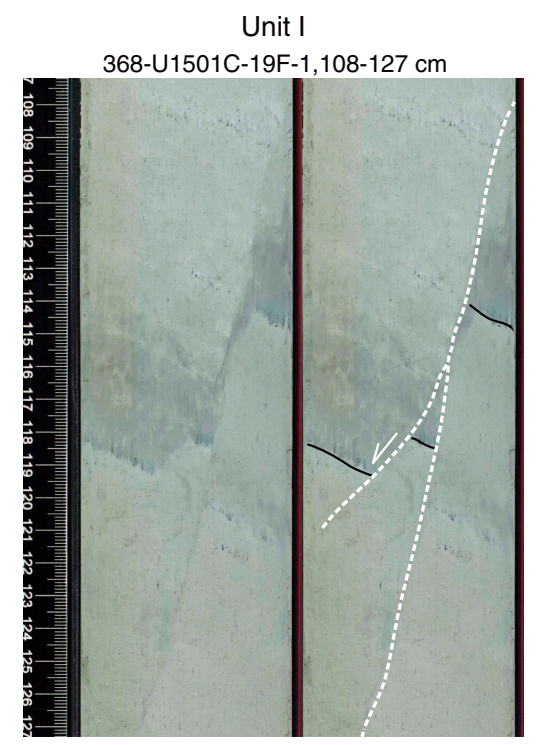

Figure F27. Deformation structures, Subunits IIA and IIB. A. Millimeter-scale normal faults and fractures. B. En echelon millimeter-scale normal faults and fractures. C. Millimeter-scale normal fault offsetting black layers from about $5 \mathrm{~mm}$ within the nannofossil-rich clay. D. Slickenslide on an exposed polished fault surface.

\section{Units IIA and IIB}

368-U1501C-48X-1, 51-77 cm

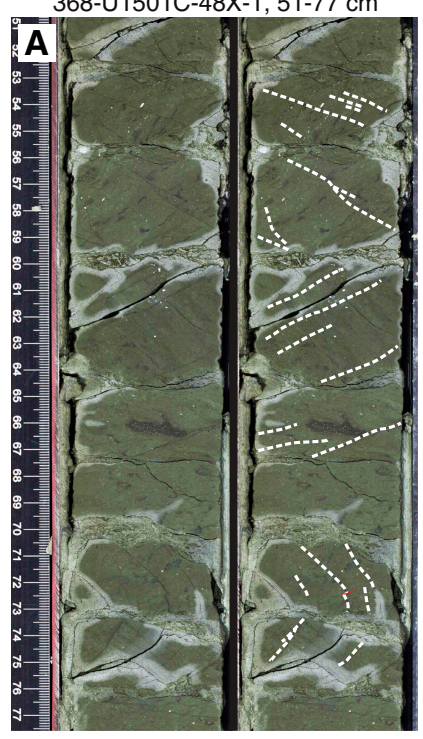

$368-U 1501 C-47 X-6,126-129 \mathrm{~cm}$
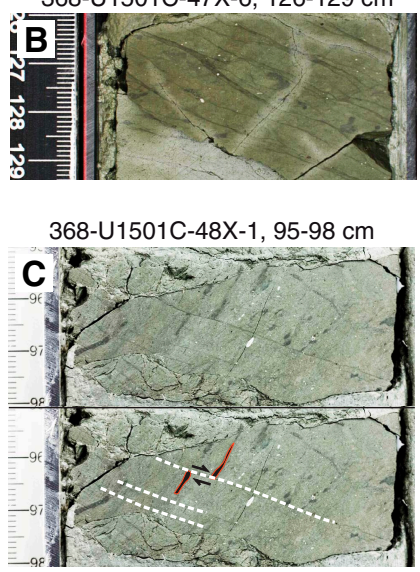

368-U1501C-59X-1, 112-114 cm

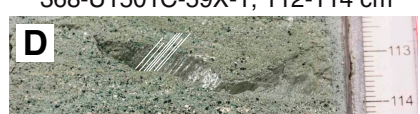

sitional conditions in Subunit IIA to deep-sea depositional conditions in Unit I.

Unit III records a slight tilting compared to Units I and II, suggesting an unconformable relationship between them. This unit was likely deposited before the main Cenozoic rifting of the SCS continental margin. Despite relatively minor evidence for internal deformation, the tilting of beds, the soft-sediment deformations, and the nature of the lithostratigraphic succession may suggest that this unit was deposited during active tectonic processes. Mesozoic basins documented onshore (e.g., Nanni et al., 2017) may represent a possible analog for the tectonic setting during Unit III deposition. 
Figure F28. Distinct uniform calcite and quartz vein shapes and structures, Subunit IIC. A, D. Single. B, C. Branched.

\section{Unit IIC}

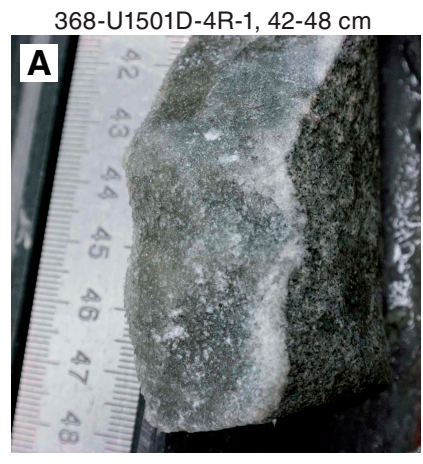

368-U1501D-7R-1, 24-28 cm
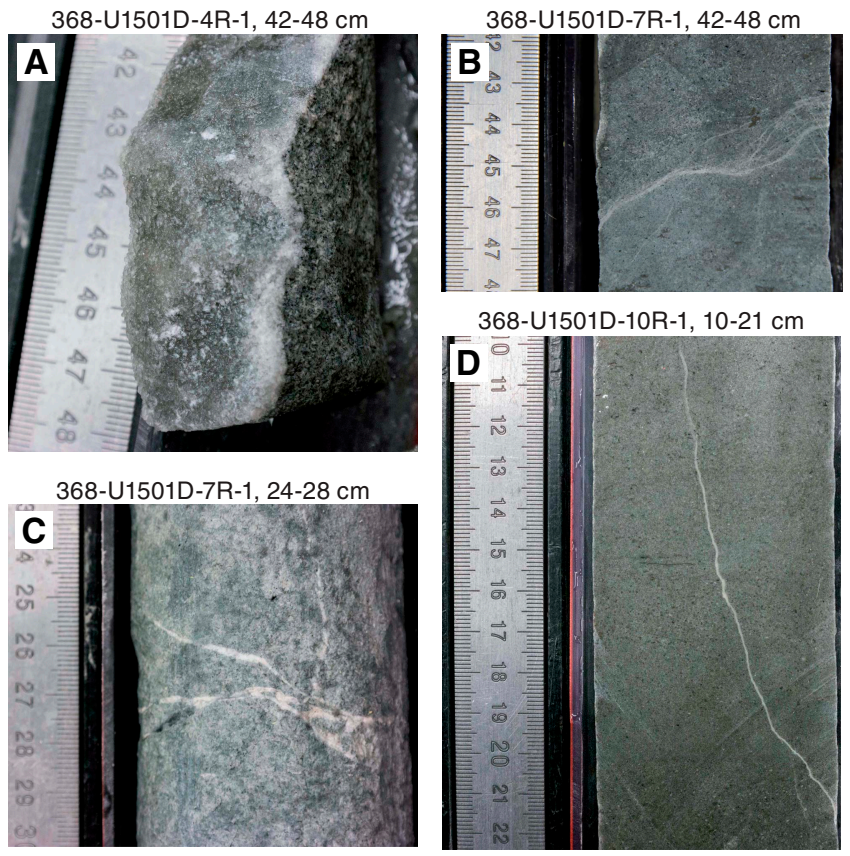

368-U1501D-10R-1, 10-21 cm

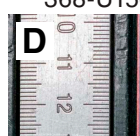

Figure F29. Deformation structures, Unit III. A. Straight fracture associated with a green alteration pattern. B. Fine-grained cataclastic fault gouge developing along a straight fracture. C. Single uniform quartz vein. D. Straight fracture associated with an alteration zone. E. En echelon uniform calcite vein. F. Convolute bedding associated with centimeter-scale slump fold.

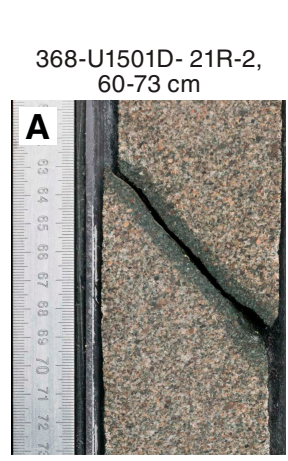

368-U1501D- 23R-3,

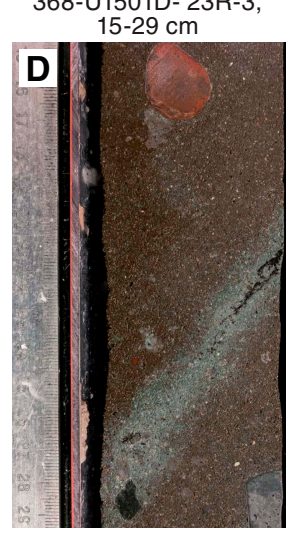

Unit III

368-U1501D- 25R-1,

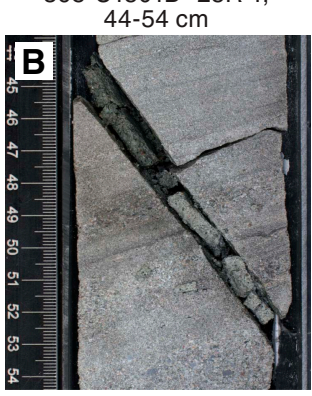

368-U1501D- 25R-2,

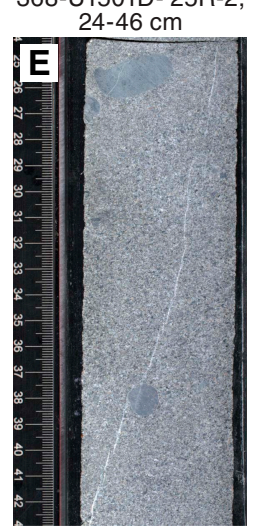

368-U1501D- 25R-1, $65-73 \mathrm{~cm}$

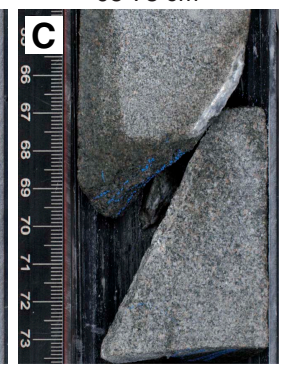

368-U1501D-26R-3,

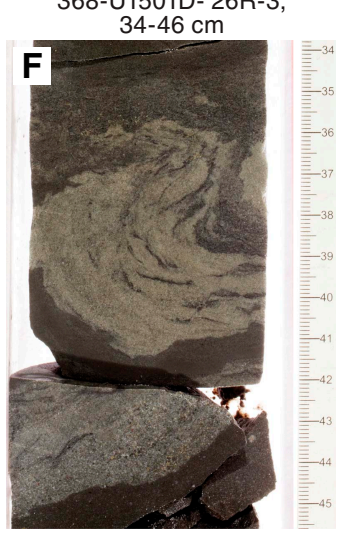

\section{Biostratigraphy}

All core catcher samples at Site U1501 were analyzed for calcareous nannofossils, planktonic and benthic foraminifers, diatoms, and ostracods. Additional samples were taken from intervals in the working-half cores when necessary to refine the ages. Preservation of calcareous microfossils is good to very good in samples from Cores 368-U1501A-1H, 368-U1501B-1H, and 368-U1501C-1H through 44X and moderate to poor in Cores 368-U1501C-45X through $62 \mathrm{X}$ and $368-\mathrm{U} 1501 \mathrm{D}-2 \mathrm{R}$ through $5 \mathrm{R}$. Samples $368-$ U1501A-1H-CC, 368-U1501B-1H-CC, and 368-U1501C-1H-CC and $2 \mathrm{H}-\mathrm{CC}$ are composed of as much as $10 \%$ diatoms with moderate preservation, whereas other core catcher samples are rare or barren of diatoms (Table T4). Planktonic foraminifers and calcareous nannofossils are abundant in Cores 368-U1501A-1H, 368U1501B-1H, and 368-U1501C-1H through 44X; rare to common in Cores 368-U1501C-45X through 62X and 368-U1501D-2R through 5R; and barren in Cores 368-U1501D-6R through 27R.

Forty biostratigraphic datums were identified in a generally continuous succession from the Holocene to the late Eocene (Tables T5, T6; Figure F30).

The Pleistocene/Pliocene boundary is placed within Core 368U1501C-7H, the Pliocene/Miocene boundary is placed within Core $9 \mathrm{H}$, the Miocene/Oligocene boundary is placed between Cores 41X and $42 \mathrm{X}$, and the Oligocene/Eocene boundary is placed between Cores 53X and 54X. Sedimentation rates varied from $\sim 13 \mathrm{~mm} / \mathrm{ky}$ in the early Oligocene to $\sim 11 \mathrm{~mm} / \mathrm{ky}$ in the early-middle Miocene, $\sim 14 \mathrm{~mm} / \mathrm{ky}$ in the Pliocene, and $24 \mathrm{~mm} / \mathrm{ky}$ in the Pleistocene. Sedimentation rates during the late Oligocene and late Miocene were much lower $(\sim 36 \mathrm{~mm} / \mathrm{ky})$, suggesting hiatuses may be present during these periods, whereas a relatively higher sedimentation rate $(35 \mathrm{~mm} / \mathrm{ky}$ ) existed during the upper late Oligocene to the lower early Miocene.

Relatively higher abundances of benthic foraminifers with dominant shallow-water marker species in Cores 368-U1501C-45X through $62 \mathrm{X}$ and $368-\mathrm{U} 1501 \mathrm{D}-2 \mathrm{R}$ through $5 \mathrm{R}$ indicate an upperslope environment during the Eocene to early Oligocene, whereas there is a higher abundance of planktonic foraminifers above Core 368-U1501C-44X, suggesting a deep ocean environment since the late Oligocene.

\section{Calcareous nannofossils}

Core catchers from Holes U1501A-U1501D were examined (Table T7). Calcareous nannofossil biostratigraphy for Site U1501 was based mainly on the analysis of all core catcher samples from Hole U1501C. To better constrain biostratigraphic events, a number of samples from intervals within cores were analyzed.

Calcareous nannofossils are very abundant and well preserved in the upper part of the succession (Cores 368-U1501C-1H through 45X). Nannofossils in samples below Section 46X-CC (321.81 m) generally degrade to low abundance and moderate preservation with intermittent abundance increases down to the bottom of Hole U1501C. In Cores 368-U1501D-2R through 5R, nannofossils are rare to common with moderate preservation. Nannofossils are barren below Section 6R-CC $(471.99 \mathrm{~m})$ to the bottom of Hole U1501D. Some of the samples from Hole U1501C exhibit signs of slight reworking, overgrowth, and fragmentation.

Twenty-four nannofossil biostratigraphic datums were recognized in the Oligocene through Pleistocene sediment sequence at Site U1501 (Table T5). The oldest nannofossil event identified at Site U1501 is the last appearance datum (LAD) of Coccolithus for- 
mosus at $379.64 \mathrm{~m}$ (Sample 368-U1501C-52X-CC), which indicates an age older than $32.92 \mathrm{Ma}$.

\section{Pleistocene}

The top of Hole U1501C (Samples 1H-CC to 2H-CC; 0-17.98 $\mathrm{m})$ is dated as late Pleistocene based on the presence of Emiliania huxleyi (marker species for Zone NN21). The LAD of Pseudoemiliania lacunosa in Sample 3H-CC (28.56 m) defines the top of

Table T4. Distribution of diatom species, Site U1501. View table in PDF format. Download table in CSV format.
Zone NN19. Zone NN19 is further divided by two nannofossil events: the LAD of large Gephyrocapsa spp. $(>5.5 \mu \mathrm{m})$ in Sample $4 \mathrm{H}-\mathrm{CC}(38.08 \mathrm{~m})$ and the LAD of Calcidiscus macintyrei in Sample $5 \mathrm{H}-\mathrm{CC}(46.95 \mathrm{~m})$. The top of Zone NN18 is marked by the LAD of Discoaster brouweri in Sample 6H-CC (57.07 m).

\section{Pliocene}

Pliocene nannofossil Zone NN16 was recognized in Hole U1501C. Two events occur in the lower part of Zone NN16: the LAD of Discoaster tamalis (2.8 Ma) in Sample 7H-CC (66.22 m) and the LAD of Sphenolithus spp. (3.54 Ma) in Sample 8H-CC (75.81

Table T5. Calcareous nannofossil biostratigraphic events, Site U1501.T = top/last appearance datum, B = bottom/first appearance datum. Download table in CSV format.

\begin{tabular}{|c|c|c|c|c|c|c|c|c|c|}
\hline \multirow{2}{*}{\multicolumn{2}{|c|}{ Epoch }} & \multirow[b]{2}{*}{$\begin{array}{c}\text { Biozone } \\
\text { (Martini, 1971) }\end{array}$} & \multirow[b]{2}{*}{$\begin{array}{l}\text { Calcareous nannofossil } \\
\text { event }\end{array}$} & \multicolumn{2}{|c|}{ Top } & \multicolumn{2}{|c|}{ Bottom } & \multicolumn{2}{|c|}{ Age model } \\
\hline & & & & $\begin{array}{l}\text { Core, } \\
\text { section }\end{array}$ & $\begin{array}{c}\text { Depth CSF-A } \\
\text { (m) }\end{array}$ & $\begin{array}{l}\text { Core, } \\
\text { section }\end{array}$ & $\begin{array}{l}\text { Depth CSF-A } \\
\text { (m) }\end{array}$ & $\begin{array}{l}\text { Depth } \\
\text { (m) }\end{array}$ & $\begin{array}{l}\text { Age } \\
(\mathrm{Ma})\end{array}$ \\
\hline \multirow{6}{*}{\multicolumn{2}{|c|}{ Pleistocene }} & & & 368-U1501C & & 368-U1501C- & & & \\
\hline & & NN21 & B Emiliania huxleyi & $2 \mathrm{H}-\mathrm{CC}$ & 17.98 & $3 \mathrm{H}-\mathrm{CC}$ & 28.56 & 23.27 & 0.29 \\
\hline & & & T Pseudoemiliania lacunosa & $2 \mathrm{H}-\mathrm{CC}$ & 17.98 & $3 \mathrm{H}-\mathrm{CC}$ & 28.56 & 23.27 & 0.44 \\
\hline & & NN19 & T Gephyrocapsa spp. $>5.5 \mu \mathrm{m}$ & $3 \mathrm{H}-\mathrm{CC}$ & 28.56 & $4 \mathrm{H}-\mathrm{CC}$ & 38.08 & 33.32 & 1.24 \\
\hline & & & T Calcidiscus macintyrei & $4 \mathrm{H}-\mathrm{CC}$ & 38.08 & $5 \mathrm{H}-\mathrm{CC}$ & 46.95 & 42.52 & 1.60 \\
\hline & & NN18 & T Discoaster brouweri & $5 \mathrm{H}-\mathrm{CC}$ & 46.95 & $6 \mathrm{H}-\mathrm{CC}$ & 57.07 & 52.01 & 1.93 \\
\hline \multirow{2}{*}{\multicolumn{2}{|c|}{ Pliocene }} & & TDiscoaster tamalis & $6 \mathrm{H}-\mathrm{CC}$ & 57.07 & 7H-CC & 66.22 & 61.65 & 2.80 \\
\hline & & TNIVIo & TSphenolithus spp. & $7 \mathrm{H}-\mathrm{CC}$ & 66.22 & $8 \mathrm{H}-\mathrm{CC}$ & 75.81 & 71.02 & 3.54 \\
\hline \multirow{11}{*}{$\begin{array}{l}\frac{\mathscr{\nu}}{\mathbb{U}} \\
\stackrel{\circ}{\Sigma} \\
\end{array}$} & \multirow{3}{*}{ late } & NN11 & T Discoaster quinqueramus & $8 \mathrm{H}-\mathrm{CC}$ & 75.81 & 9H-CC & 85.50 & 80.66 & 5.59 \\
\hline & & NN11 & B Discoaster berggrenii & $10 \mathrm{H}-\mathrm{CC}$ & 94.91 & $11 \mathrm{H}-\mathrm{CC}$ & 104.91 & 99.91 & 8.29 \\
\hline & & NN8 & B Catinaster coalitus & $11 \mathrm{H}-\mathrm{CC}$ & 104.91 & $12 \mathrm{H}-\mathrm{CC}$ & 113.97 & 109.44 & 10.89 \\
\hline & \multirow{4}{*}{ middle } & NN7 & T Discoaster kugleri & $13 \mathrm{H}-\mathrm{CC}$ & 123.83 & $14 \mathrm{H}-\mathrm{CC}$ & 131.53 & 127.68 & 11.58 \\
\hline & & NN6 & T Cyclicargolithus floridanus & $14 \mathrm{H}-\mathrm{CC}$ & 131.53 & $15 \mathrm{H}-\mathrm{CC}$ & 142.19 & 136.86 & 11.85 \\
\hline & & NN5 & TSphenolithus heteromorphus & $15 \mathrm{H}-\mathrm{CC}$ & 142.19 & $16 \mathrm{H}-\mathrm{CC}$ & 151.80 & 147.00 & 13.53 \\
\hline & & NN4 & T Helicosphaera ampliaperta & $21 \mathrm{~F}-\mathrm{CC}$ & 175.97 & $22 \mathrm{~F}-\mathrm{CC}$ & 180.60 & 178.29 & 14.91 \\
\hline & \multirow{4}{*}{ early } & \multirow{4}{*}{ NN2 } & TTriquetrorhabdulus carinatus & $23 \mathrm{~F}-\mathrm{CC}$ & 184.45 & $24 \mathrm{~F}-\mathrm{CC}$ & 189.47 & 186.96 & 18.28 \\
\hline & & & B Sphenolithus belemnos & $26 \mathrm{~F}-\mathrm{CC}$ & 198.38 & $27 \mathrm{~F}-\mathrm{CC}$ & 204.08 & 201.23 & 19.03 \\
\hline & & & B Helicosphaera ampliaperta & $27 \mathrm{~F}-\mathrm{CC}$ & 204.08 & $28 \mathrm{~F}-\mathrm{CC}$ & 208.70 & 206.39 & 20.43 \\
\hline & & & B Sphenolithus disbelemnos & $40 X-C C$ & 265.35 & $41 X-C C$ & 273.91 & 269.63 & 22.76 \\
\hline \multirow{6}{*}{\multicolumn{2}{|c|}{ Oligocene }} & NN1 & T Sphenolithus delphix & $41 \mathrm{X}-\mathrm{CC}$ & 273.91 & $42 \mathrm{X}-\mathrm{CC}$ & 283.46 & 278.69 & 23.11 \\
\hline & & NP25 & T Sphenolithus ciperoensis & $43 \mathrm{X}-\mathrm{CC}$ & 293.15 & $44 \mathrm{X}-\mathrm{CC}$ & 302.56 & 297.86 & 24.43 \\
\hline & & NP24 & TSphenolithus predistentus & $44 X-C C$ & 302.56 & $45 X-C C$ & 312.20 & 307.38 & 26.93 \\
\hline & & NP24 & B Sphenolithus ciperoensis & $45 \mathrm{X}-\mathrm{CC}$ & 312.20 & $46 \mathrm{X}-\mathrm{CC}$ & 321.81 & 317.01 & 29.62 \\
\hline & & NP22 & T Reticulofenestra umbilicus & $48 \mathrm{X}-\mathrm{CC}$ & 340.46 & $49 \mathrm{X}-\mathrm{CC}$ & 350.49 & 345.48 & 32.02 \\
\hline & & NP21 & T Coccolithus formosus & $51 X-C C$ & 369.98 & $52 X-C C$ & 379.64 & 374.81 & 32.92 \\
\hline
\end{tabular}

Table T6. Planktonic foraminifer events, Site U1501. T = top/last appearance datum, B = bottom/first appearance datum, BC = bottom/first common appearance datum (acme). Download table in CSV format.

\begin{tabular}{|c|c|c|c|c|c|c|c|c|}
\hline \multirow[b]{2}{*}{ Epoch } & \multirow[b]{2}{*}{$\begin{array}{c}\text { Biozone } \\
\text { (Blow, 1969) }\end{array}$} & \multirow[b]{2}{*}{ Events } & \multicolumn{2}{|c|}{ Top } & \multicolumn{2}{|c|}{ Bottom } & \multicolumn{2}{|c|}{ Age model } \\
\hline & & & Core, section & $\begin{array}{l}\text { Depth CSF-A } \\
(\mathrm{m})\end{array}$ & Core, section & $\begin{array}{c}\text { Depth CSF-A } \\
(\mathrm{m})\end{array}$ & $\begin{array}{l}\text { Depth } \\
\text { (m) }\end{array}$ & $\begin{array}{l}\text { Age } \\
\text { (Ma) }\end{array}$ \\
\hline \multirow{5}{*}{ Pleistocene } & & & 368-U1501C- & & 368-U1501C- & & & \\
\hline & $\mathrm{N} 22$ & T Globigerinoides ruber (pink) & $1 \mathrm{H}-\mathrm{CC}$ & 9.24 & $2 \mathrm{H}-\mathrm{CC}$ & 17.98 & 13.61 & 0.12 \\
\hline & $\mathrm{N} 22$ & Bc Globigerinoides ruber (pink) & $2 \mathrm{H}-\mathrm{CC}$ & 17.98 & $3 \mathrm{H}-\mathrm{CC}$ & 28.56 & 23.27 & 0.40 \\
\hline & $\mathrm{N} 22$ & T Globigerinoides fistulosus & $4 \mathrm{H}-\mathrm{CC}$ & 38.08 & $5 \mathrm{H}-\mathrm{CC}$ & 46.95 & 42.52 & 1.88 \\
\hline & $\mathrm{N} 20-\mathrm{N} 21$ & T Globorotalia multicamerata & $5 \mathrm{H}-\mathrm{CC}$ & 46.95 & $6 \mathrm{H}-\mathrm{CC}$ & 57.07 & 52.01 & 2.18 \\
\hline \multirow{2}{*}{ Pliocene } & $\mathrm{N} 20-\mathrm{N} 21$ & T Dentoglobigerina altispira & 7H-CC & 66.22 & $8 \mathrm{H}-\mathrm{CC}$ & 75.81 & 71.02 & 3.47 \\
\hline & N19 & T Globoturborotalita nepenthes & $8 \mathrm{H}-\mathrm{CC}$ & 75.81 & $9 \mathrm{H}-\mathrm{CC}$ & 85.05 & 80.66 & 4.37 \\
\hline \multirow{6}{*}{ Miocene } & N17 & T Globoquadrina dehiscens & $10 \mathrm{H}-\mathrm{CC}$ & 94.91 & $11 \mathrm{H}-\mathrm{CC}$ & 104.91 & 99.91 & 5.92 \\
\hline & $\mathrm{N} 12$ & T Fohsella fohsi & $12 \mathrm{H}-\mathrm{CC}$ & 113.48 & $13 \mathrm{H}-\mathrm{CC}$ & 123.83 & 118.66 & 11.79 \\
\hline & N8 & B Praeorbulina sicana & $22 \mathrm{~F}-\mathrm{CC}$ & 180.60 & $23 \mathrm{~F}-\mathrm{CC}$ & 184.45 & 182.53 & 16.38 \\
\hline & N6 & T Catapsydrax dissimilis & $24 \mathrm{~F}-\mathrm{CC}$ & 189.47 & $25 \mathrm{~F}-\mathrm{CC}$ & 193.35 & 191.41 & 17.54 \\
\hline & N5 & T Globoquadrina binaiensis & $27 \mathrm{~F}-\mathrm{CC}$ & 204.08 & $28 \mathrm{~F}-\mathrm{CC}$ & 208.70 & 206.39 & 19.09 \\
\hline & N4 & T Paragloborotalia kugleri & $32 \mathrm{~F}-\mathrm{CC}$ & 226.47 & $33 \mathrm{~F}-\mathrm{CC}$ & 231.83 & 229.15 & 21.12 \\
\hline \multirow{3}{*}{ Oligocene } & N4 & T Globigerina ciperoensis & $40 \mathrm{X}-\mathrm{CC}$ & 265.35 & $41 \mathrm{X}-\mathrm{CC}$ & 273.91 & 269.63 & 22.90 \\
\hline & $\mathrm{P} 21$ & T Paragloborotalia opima & $43 X-C C$ & 293.15 & $44 \mathrm{X}-\mathrm{CC}$ & 302.56 & 297.86 & 26.93 \\
\hline & P19 & T Turborotalia ampliapertura & $46 \mathrm{X}-\mathrm{CC}$ & 321.81 & $47 X-C C$ & 331.18 & 326.50 & 30.28 \\
\hline Eocene & P18 & T Globigerinatheka subconglobata & $53 \mathrm{X}-\mathrm{CC}$ & 385.33 & $54 X-C C$ & 398.79 & 392.06 & 33.89 \\
\hline
\end{tabular}


Figure F30. Age-depth model, Site U1501. Plotted event data are in Tables T6, T7, and T13 (see Paleomagnetism; Figure F40).
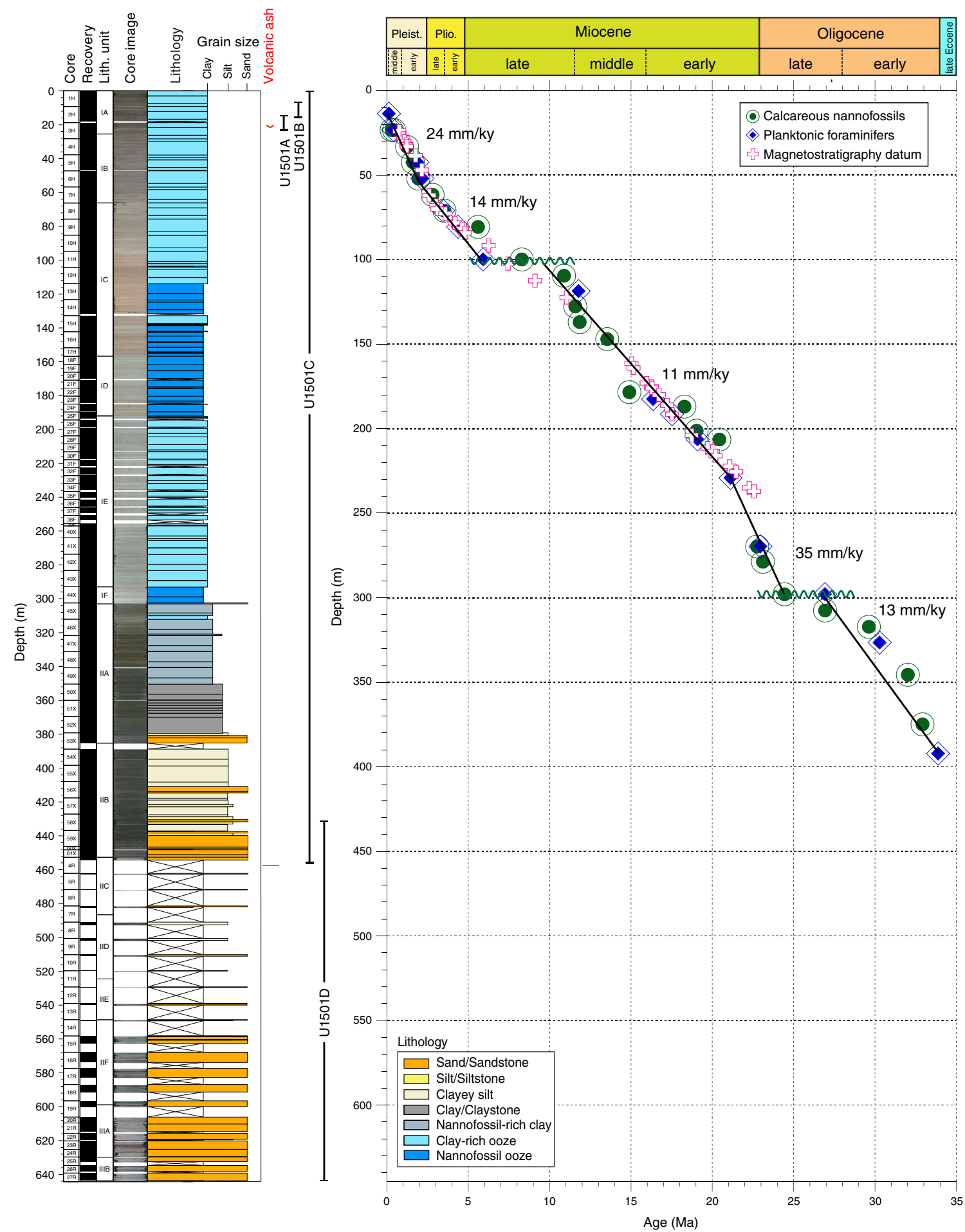

$\mathrm{m})$. The Miocene/Pliocene boundary in Hole U1501C is placed between Samples $8 \mathrm{H}-\mathrm{CC}(75.81 \mathrm{~m})$ and $9 \mathrm{H}-\mathrm{CC}(85.5 \mathrm{~m})$ based on the LADs of Sphenolithus spp. (3.54 Ma) and Discoaster quinqueramus (5.59 Ma), respectively.

\section{Miocene}

Three events occur in the upper Miocene strata of Hole U1501C. The top of Zone NN11 is defined by the LAD of D. quin- queramus $(5.59 \mathrm{Ma})$ in Sample $9 \mathrm{H}-\mathrm{CC}(85.5 \mathrm{~m})$. The first appearance datum (FAD) of Discoaster berggrenii (8.29 Ma) was found in Sample 10H-CC $(94.91 \mathrm{~m})$. The FAD of Catinaster coalitus was used to mark the base of Zone NN8 (10.89 Ma) in Sample 11H-CC $(104.91 \mathrm{~m})$. The late/middle Miocene boundary in Hole U1501C was assigned between Samples 11H-CC (104.91 m) and 14H-CC (131.53 m) based on the FAD of C. coalitus (10.89 Ma) and the LAD of Discoaster kugleri (11.58 Ma), respectively. 
Table T7. Nannofossil abundance, Site U1501. View table in PDF format. Download table in CSV format.

Four events occur in the middle Miocene strata of Hole U1501C. The LAD of D. kugleri (11.58 Ma) within Zone NN7 occurs in Sample 14H-CC (131.53 m). The top of Zone NN6 is marked by the LAD of Cyclicargolithus floridanus (11.85 Ma) in Sample $15 \mathrm{H}-\mathrm{CC}(142.19 \mathrm{~m})$. The top of Zone NN5 is marked by the LAD of Sphenolithus heteromorphus (13.53 Ma) in Sample 16H-CC (151.8 $\mathrm{m})$. The top of Zone NN4 is defined by the LAD of Helicosphaera ampliaperta (14.91 Ma) in Sample 22F-CC (180.6 m). The middle/early Miocene boundary was assigned between Samples 22FCC (180.6 m) and 24F-CC (189.47 m).

Four events occur in the lower Miocene strata of Hole U1501C. The top of Zone NN2 is marked by the LAD of Triquetrorhabdulus carinatus (18.28 Ma) in Sample 24F-CC (189.47 m). The bottom of Zone NN2 is approximated by the FAD of Sphenolithus disbelemnos $(22.76 \mathrm{Ma})$ in Sample 40X-CC (265.35 m). Two additional events were found in Zone NN2: the FAD of Sphenolithus belemnos (19.03 $\mathrm{Ma})$ in Sample 26F-CC (198.38 m) and the FAD of H. ampliaperta (20.43 Ma) in Sample 27F-CC (204.08 m). The Miocene/Oligocene boundary was assigned between Samples 40X-CC (265.35 m) and 42X-CC (283.46 m) based on the FAD of S. disbelemnos (22.76 Ma) and the LAD of Sphenolithus delphix (23.11 Ma), respectively.

\section{Oligocene}

Six events were identified in the Oligocene strata of Hole U1501C. The LAD of S. delphix (23.11 Ma) within Zone NN1 occurs in Sample 42X-CC (283.46 m), the LAD of Sphenolithus ciperoensis (24.43 Ma) within Zone NP25 occurs in Sample 44X-CC $(302.56 \mathrm{~m})$, and the LAD of Sphenolithus predistentus (26.93 Ma) and FAD of S. ciperoensis (29.62 Ma) within Zone NP24 occur in Sample 45X-CC (312.2 m). The top of Zone NP22 is marked by the LAD of Reticulofenestra umbilicus (32.02 Ma) in Sample 49X-CC $(350.49 \mathrm{~m})$. The top of Zone NP21 is marked by the LAD of C. formosus (32.92 Ma) in Sample 52X-CC (379.64 m).

From Sample 52X-CC (379.64 m) to the bottom of Hole U1501C (Sample 62X-CC, $457.83 \mathrm{~m}$ ), the nannofossil assemblage includes Chiasmolithus altus, C. formosus, Discoaster nodifer, Discoaster tani, Discoaster williamsii, Helicosphaera bramlettei, Helicosphaera recta, Helicosphaera compacta, Lanternithus minutus, Pontosphaera exilis, Pontosphaera punctosa, Reticulofenestra circus, Reticulofenestra, R. umbilicus, Reticulofenestra erbae, and Reticulofenestra lockeri. Such a nannofossil assemblage indicates a late Eocene age for the base of Hole U1501C.

The nannofossil assemblages in Cores 368-U1501D-2R through $5 \mathrm{R}$ are similar to those in samples from the bottom part of Hole U1501C, so they were also assigned to the late Eocene. Nannofossils are barren from Sample 6R-CC $(471.99 \mathrm{~m})$ to the bottom of Hole U1501D, so we cannot determine the age of these samples.

\section{Planktonic foraminifers}

All core catcher samples and several additional samples from the split cores in Holes U1501A-U1501D were processed for planktonic foraminiferal analyses (Table T8). Planktonic foraminifers are well preserved and abundant for samples from Cores 368-U1501A$1 \mathrm{H}, 368-\mathrm{U} 1501 \mathrm{~B}-1 \mathrm{H}$, and $368-\mathrm{U} 1501 \mathrm{C}-1 \mathrm{H}$ through $44 \mathrm{X}$ and moderate to poorly preserved or even recrystallized and less abundant in Cores 368-U1501C-45X through 62X.
Table T8. Distribution of planktonic foraminifers, Site U1501. View table in PDF format. Download table in CSV format.

Only one core was drilled in Holes U1501A and U1501B. Abundant pink Globigerinoides ruber specimens were observed in the core catcher samples, indicating an age between 0.12 and $0.4 \mathrm{Ma}$ for the bottom of these two holes. No planktonic foraminifer was observed in Hole U1501D.

Sixteen planktonic foraminiferal datums were recognized in Hole U1501C, spanning the late Eocene $(<37.75 \mathrm{Ma})$ to the late Pleistocene (Plate P1; Table T6). The planktonic foraminiferal biostratigraphy for Hole U1501C was established by these events and the planktonic foraminiferal assemblages at successive depth intervals.

The Pleistocene planktonic foraminifers are composed of G. ruber, Globigerinoides sacculifer, Globorotalia menardii, Pulleniatina obliquiloculata, and Neogloboquadrina dutertrei. The LAD of pink G. ruber (0.12 Ma) and FAD of pink G. ruber acme (0.40 Ma) are placed between Samples $1 \mathrm{H}-\mathrm{CC}$ and $2 \mathrm{H}-\mathrm{CC}$ and Samples $2 \mathrm{H}-\mathrm{CC}$ and $3 \mathrm{H}-\mathrm{CC}$, respectively. The LAD of Globigerinoides fistulosus $(1.88 \mathrm{Ma})$ is located between Samples $4 \mathrm{H}-\mathrm{CC}$ and $5 \mathrm{H}-\mathrm{CC}$ and marks the Zone N22/N21 boundary. The LAD of Globorotalia multicamerata $(2.18 \mathrm{Ma})$ is located between Samples $5 \mathrm{H}-\mathrm{CC}$ and $6 \mathrm{H}-\mathrm{CC}$.

The Pliocene planktonic foraminiferal assemblage is characterized by the higher content of Dentoglobigerina altispira and Sphaeroidinellopsis seminulina. The LAD of D. altispira (3.47 Ma) is located between Samples 7H-CC and 8H-CC. The LAD of Globoturborotalita nepenthes (4.37 Ma) is located between Samples $8 \mathrm{H}-\mathrm{CC}$ and $9 \mathrm{H}-\mathrm{CC}$ and defines the Zone N20/N19 boundary.

The middle-late Miocene foraminiferal assemblage is dominated by D. altispira, Globoquadrina dehiscens, and Praeorbulina circularis/glomerosa. The LAD of G. dehiscens (5.92 Ma) is located between Samples 10H-CC and 11H-CC and defines the boundary of Zones N18/N17. The LAD of Fohsella fohsi (11.79 Ma) is located between Samples 12H-CC and 13H-CC and defines the boundary of Zones N13/N12. The FAD of Praeorbulina sicana (16.38 Ma) is located between Samples 22F-CC and 23F-CC and marks the boundary of Zones N8/N7.

The late Oligocene-early Miocene planktonic foraminifers are characterized by G. dehiscens, Globoquadrina venezuelana, and Paragloborotalia mayeri. The LAD of Catapsydrax dissimilis (17.54 Ma) is located between Samples 24F-CC and 25F-CC and defines the boundary of Zones N7/N6. The LAD of Globoquadrina binaiensis (19.09 Ma) is located between Samples 27F-CC and 28FCC. The LAD of Paragloborotalia kugleri (21.12 Ma) is located between Samples 32F-CC and 33F-CC as the boundary of Zones $\mathrm{N} 5 / \mathrm{N} 4$. The LAD of Globigerina ciperoensis (22.90 Ma) is located between Samples 40X-CC and 41X-CC and represents the Miocene/Oligocene boundary.

Compared to the large planktonic foraminiferal components during the late Oligocene-early Miocene, the early Oligocene planktonic foraminifers are characterized by small Paragloborotalia nana and Paragloborotalia opima. The LAD of P. opima (26.93 Ma) is located between Samples 43X-CC and 44X-CC as the boundary of Zones P22/P21. The LAD of Turborotalia ampliapertura $(30.28$ $\mathrm{Ma}$ ) is located between Samples 46X-CC and 47X-CC as the boundary of Zones P20/P19. 
Plate P1. Principal planktonic foraminifers from Hole U1501C used in biostratigraphy analyses for Site U1501. 1: optical; 2-14: SEM. Scale bar $=100 \mu$ m. 1. Globigerinoides ruber pink (1H-CC). 2. Globigerinoides fistulosus (5H-CC). 3. Globorotalia multicamerata (7H-CC). 4. Dentoglobigerina altispira (9H-CC). 5. Globoturborotalita nepenthes (8H-CC). 6. Globoquadrina dehiscens (11H-CC). 7. Fohsella fohsi (15H-CC). 8. Praeorbulina sicana (23F-CC). 9. Catapsydrax dissimilis (26F-CC). 10. Globoquadrina binaiensis (28H-CC). 11. Paragloborotalia kugleri (32F-CC). 12. Globigerina ciperoensis (51X-CC). 13. Paragloborotalia opima (44X-CC). 14. Globigerinatheka subconglobata (54X-CC).

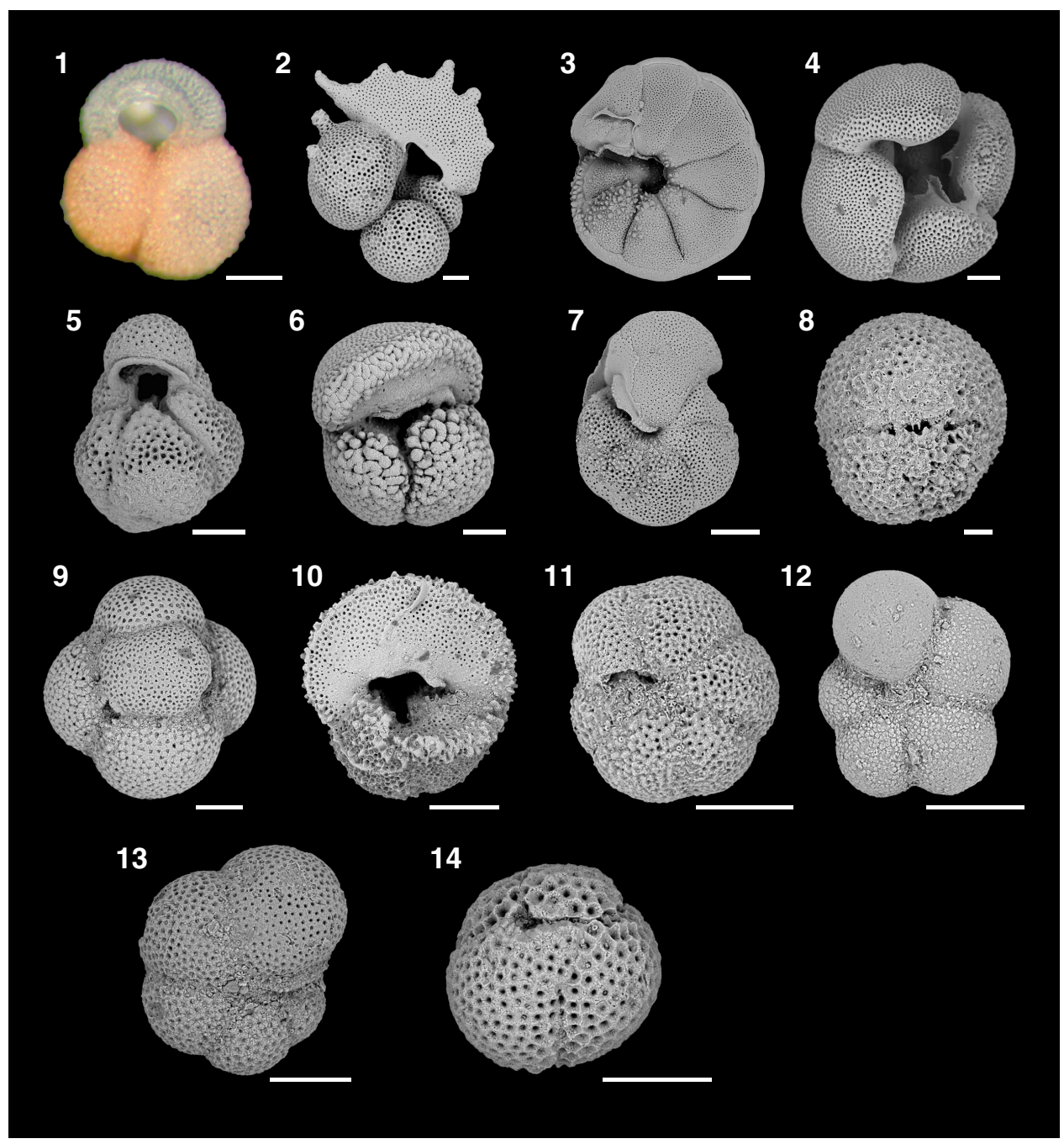

In Sample 54X-CC, late Eocene planktonic foraminiferal components such as Globigerinatheka subconglobata and Globigerinatheka index rubriformis were observed, suggesting a late Eocene age. Because of the low abundance and poor preservation of the planktonic foraminifers in Samples 368-U1501C-55X-CC to 62X$\mathrm{CC}$ and their absence from Samples 368-U1501D-2R-CC to 27RCC, a definite age for the lowest part of Holes U1501C and U1501D could not be determined.

\section{Benthic foraminifers}

Benthic foraminifers in Samples 368-U1501C-41X-CC to 62X$\mathrm{CC}$ and 368-U1501D-2R-CC to 4R-CC were counted ( 300 random specimens) from the $>150 \mu \mathrm{m}$ size fraction (Figure F31). Benthic foraminifers are abundant in Samples 368-U1501C-46X-CC and 368-U1501D-4R-CC and are more abundant than planktonic foraminifers in samples deeper than Sample 368-U1501C-54X-CC. Bulimina spp., Melonis spp., Cibicidoides spp., Lenticulina spp., and some agglutinated benthic foraminifers were observed in these samples. From the planktonic foraminifer/total foraminifer ratios, it is inferred that the paleoenvironment at this site changed from shelf (Samples 368-U1501C-54X-CC and 368-U1501D-4R-CC) to upper slope (Samples U1501C-46X-CC to 53X-CC) and then to deep sea (Samples 41X-CC to 45X-CC), clearly indicating an increasing water depth.

\section{Diatoms}

Core catcher samples from Holes U1501A-U1501D were processed into smear and strewn slides for diatom analysis. An additional 21 toothpick samples were taken from selected intervals of the working-half cores for better resolution. Samples 368-U1501A$1 \mathrm{H}-\mathrm{CC}, 368-\mathrm{U} 1501 \mathrm{~B}-1 \mathrm{H}-\mathrm{CC}$, and 368-U1501C-1H-CC and 2H-CC are composed of as much as $10 \%$ diatoms with moderate preservation. Smear slides from Samples 368-U1501C-3H-CC, 4H-CC, 35F$\mathrm{CC}, 45 \mathrm{X}-\mathrm{CC}$, and $46 \mathrm{X}-\mathrm{CC}$ contain $<1 \%$ diatoms with poor preservation. The rest of the core catcher samples from Cores 368U1501C-5H through $62 \mathrm{X}$ and 368-U1501D-2R through $27 \mathrm{R}$ are barren of diatoms (Table T4). 
Figure F31. Statistics of benthic foraminifers (368-U1501C-41X-CC to 62X-CC and 368-U1501D-2R-CC to 4R-CC). $B=$ barren, $P=$ present, $R=$ rare, $F=$ few, $A=$ abundant, $\mathrm{D}=$ dominant.

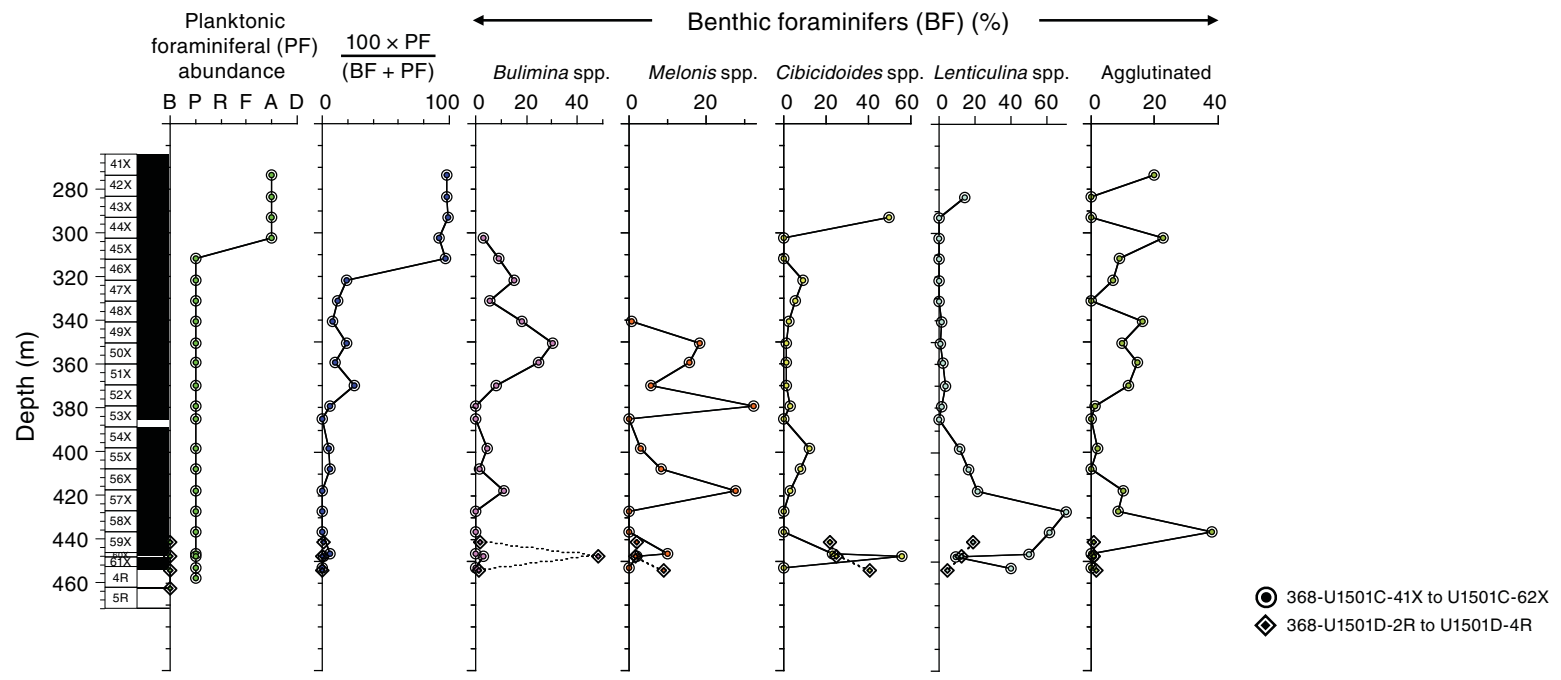

Toothpick samples of burrows in the working-half sections of Holes U1501C and U1501D were found to contain between $0 \%$ and $60 \%$ diatoms with poor to moderate preservations. Samples 368U1501A-1H-CC, 368-U1501B-1H-CC, and 368-U1501C-1H-CC and $2 \mathrm{H}-\mathrm{CC}$ contain a few specimens of Fragilariopsis doliolus, indicating an age of 2.0-0.6 Ma. A smear slide of a partially pyritized burrow in Sample 368-U1501C-35F-1, $118 \mathrm{~cm}$, contains a few specimens of Azpetia bukryi with Cestodiscus trochus commonly observed, indicating an age range between 20.8 and $30.8 \mathrm{Ma}$ (Table T9).

\section{Ostracods}

A preliminary examination of ostracods was conducted in core catcher samples from Holes U1501C and U1501D (Table T10) to characterize the assemblage variability through time and to reconstruct paleoenvironmental changes throughout the Cenozoic. Ostracod abundance ranges from absent to $>60$ valves per sample, and preservation varies from good (mostly in the Pleistocene section) to poor, although most specimens are moderately preserved. The highest incidences of ostracods were observed in Samples 368U1501C-10H-CC to $16 \mathrm{H}-\mathrm{CC}$ (94-151 m), 27F-CC to 31F-CC (204$221 \mathrm{~m}), 40 X-C C$ to $43 X-C C$ (265-293 m), and in particular Samples
49X-CC to 51X-CC (350.44-369.9 m) and 60X-CC (447.92 m). In Hole U1501D, ostracods are only present in Samples 2R-CC to 6RCC.

In Hole U1501C, lower bathyal to abyssal genera (Krithe, Legitimocythere, Henryhowella, Bradleya, Abyssocythereis, Argilloecia, Pennyella, Poseidonamicus, Pelecocythere, Arcacythere, Cytheropteron, Eucythere, Abyssocythere, and Parakrithe) dominate the Oligocene through Pleistocene assemblage, indicating that deepwater conditions have existed in the SCS since the early Oligocene. Below $349 \mathrm{~m}$ (Sample 50X-CC, 40-45 cm, estimated to be of late Eocene age), the assemblage is characterized by upper bathyal and continental shelf taxa (e.g., Heinia, Cytheropteron, Xestoleberis, Abrocythereis, Neomonoceratina, Trachyleberis, Cytherelloidea, and Cytherella), although deep-sea genus Krithe remains present. In Hole U1501D, Samples 2R-2, 111-114 cm, and 4R-CC to 6R-CC (estimated to be middle to late Eocene in age) are composed of Paranesidea sp., Cytherelloidea cf. Cytherelloidea asatoensis Nohara, Coquimba sp., Schizocythere? sp., and Paijenborchella sinensis, among others. Paleoecologically, the absence of abyssal to upper bathyal or brackish water taxa in the assemblage indicates a shallow-marine environment (Plates P2, P3). 
Table T9. Diatom biostratigraphic events, Site U1501.T = top/last appearance datum, B = bottom/first appearance datum. Download table in CSV format.

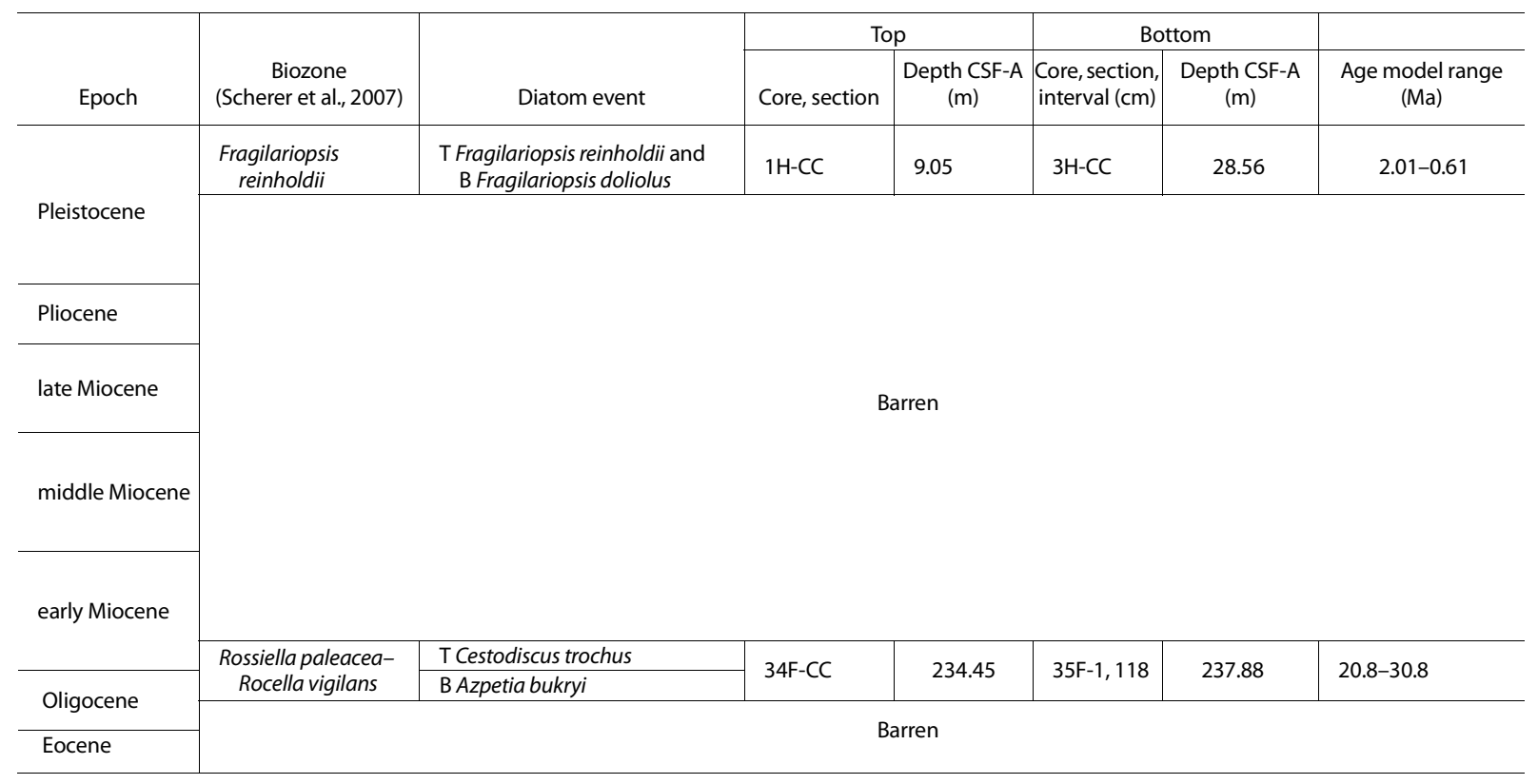

Table T10. Distribution of ostracods, Holes U1501C and U1501D. View table in PDF format. Download table in CSV format.

Plate P2. Representative Miocene to Pleistocene abyssal ostracods, Hole U1501C. 1. Henryhowella sp. (1H-CC). 2. Legitimocythere sp. (1H-CC). 3. Krithe sp. (3H-CC). 4. Poseidonamicus cf. Poseidonamicus pintoi Benson, 1972 (6HCC). 5. Pennyella sp. (12H-CC). 6. Cytheropteron cf. Cytheropteron uchioi Hanai, 1957 (13H-CC). 7. Bradleya cf. Bradleya metamorphica Whatley et al. $(14 \mathrm{H}-$ CC). 8. Arcacythere sp. (43X-CC).

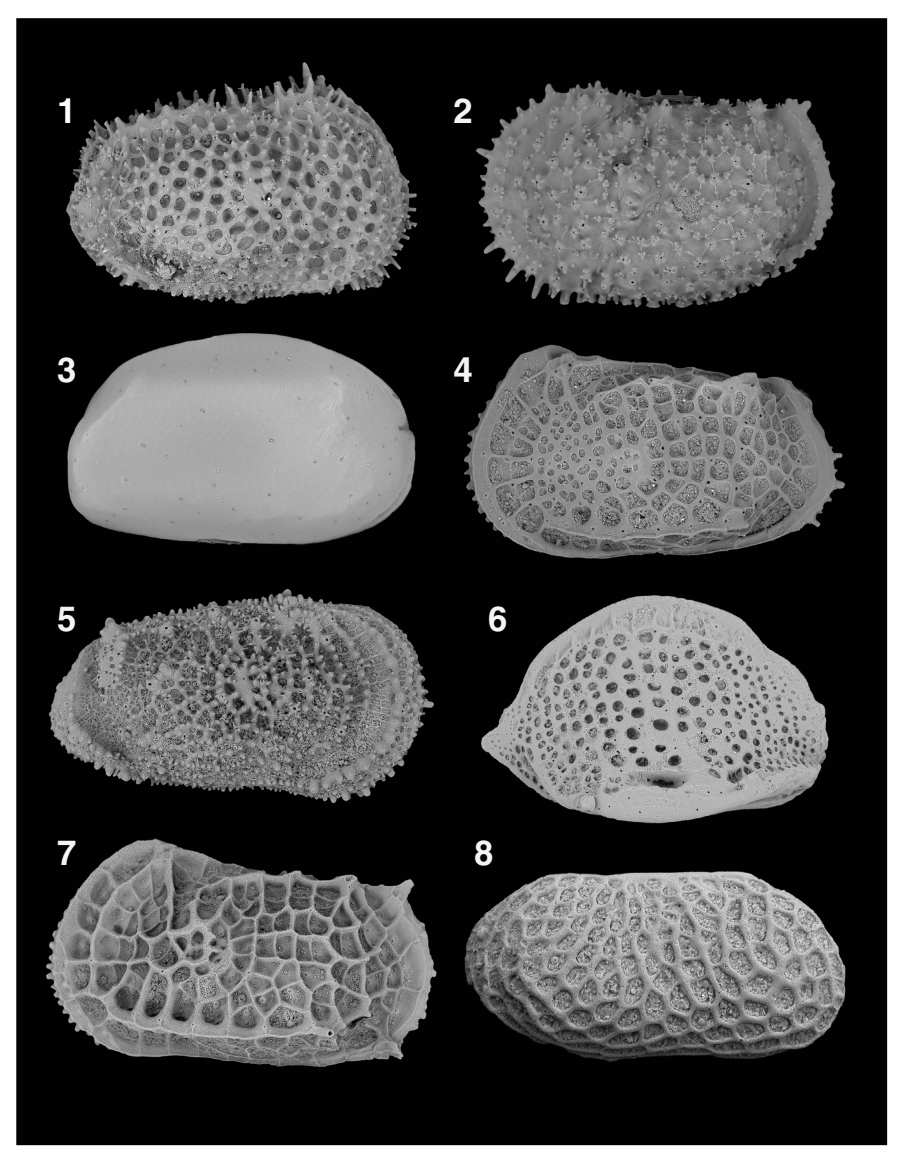

Plate P3. Representative late Eocene shallow-water marine ostracods, Hole U1501D. 1. Cytherelloidea sp. C (4R-CC). 2. Cytherelloidea cf. Cytherelloidea asatoensis Nohara (4R-CC). 3. Schizocythere? sp. (4R-CC). 4. Paijenborchella sinensis (Liu, 1989) (4R-CC). 5. Paranesidea sp. (4R-CC). 6. Coquimba sp. (4RCC).

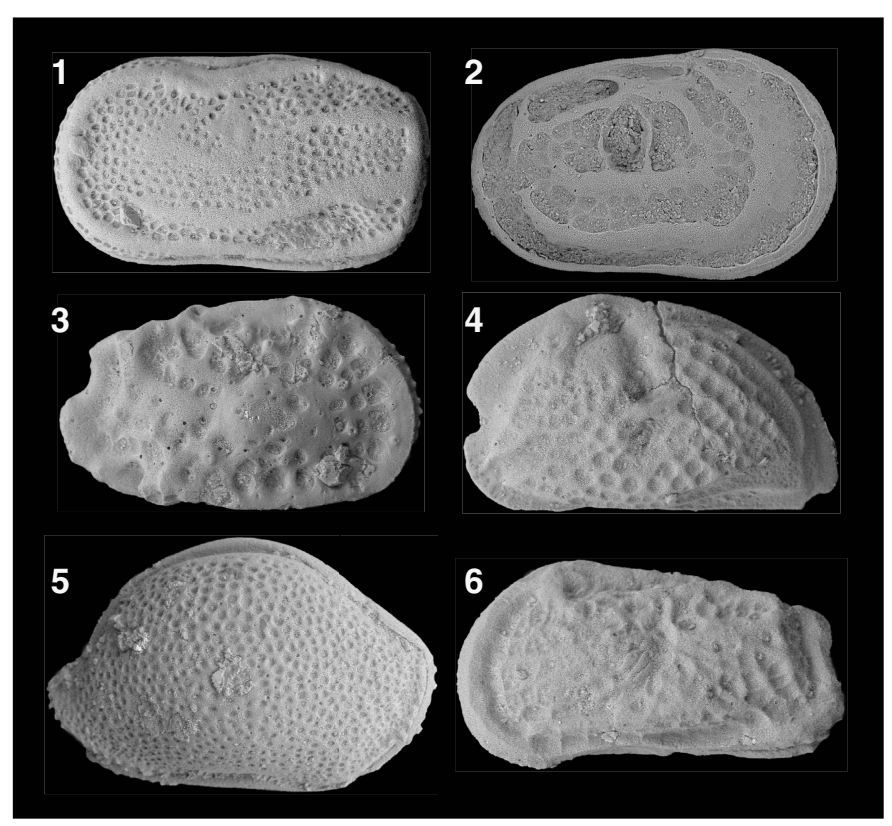




\section{Paleomagnetism Shipboard measurements}

Shipboard paleomagnetic investigations combined three complementary approaches (see Paleomagnetism in the Expedition 367/368 methods chapter [Sun et al., 2018a]): (1) measurement and in-line AF demagnetization of archive-half sections on the passthrough 2G Enterprises SRM, (2) measurement and thermal demagnetization of oriented discrete samples on the SRM, and (3) measurement and AF demagnetization of oriented discrete samples on the spinner magnetometer (Agico JR-6A). Representative discrete samples were collected from every two sections ( $3 \mathrm{~m})$, except where drilling disturbance was high or where core recovery was low.

First, we used scalar data from AF demagnetization up to $50 \mathrm{mT}$ and thermal demagnetization on discrete samples to constrain the nature of the magnetic assemblage. Second, we used the directional and intensity data of archive-half sections, measured after the highest in-line AF demagnetization step ( $25 \mathrm{mT})$, to determine magnetic polarity along the core. Third, we used the directional and intensity data from discrete samples to validate the polarities inferred from section measurements. Directional data were analyzed using $\mathrm{Zij}$ derveld diagrams (Zijderveld, 1967), and the characteristic remanent magnetization (ChRM) direction(s) were calculated by principal component analysis (PCA) (Kirschvink, 1980) using the software PuffinPlot (version 1.03, 23 April, 2015) (Lurcock and Wilson, 2012).

\section{Demagnetization behavior and implications for magnetic assemblages}

Stepwise demagnetization of the NRM shows that $91 \%$ of analyzed samples lost the bulk of their magnetic remanence between $200^{\circ}$ and $300^{\circ} \mathrm{C}$. For all steps of thermal demagnetization, the cumulative behavior of all samples was analyzed (each sample having the same statistical weight). The loss of remanent magnetization was normalized to NRM and expressed as a percentage (Figure F32). This behavior shows that one or several phases with low $T_{\mathrm{C}}$, such as pyrrhotite $\left(T_{\mathrm{C}} \approx 325^{\circ} \mathrm{C}\right.$; Tauxe, 2010$)$ or greigite $\left(T_{\mathrm{C}} \approx 330^{\circ} \mathrm{C}\right.$; Tauxe, 2010 ), dominate the NRM. High SIRM/ $X$ ratios are widely considered characteristic of greigite in sediments (e.g., Snowball, 1991; Roberts, 1995; Roberts et al., 2011). The rock magnetic experiments on six representative samples from Hole U1501C (Table T11), after magnetic saturation at $2.3 \mathrm{~T}$, show SIRM/ $\mathrm{X}$ between 12.8 and 14.6 $\mathrm{kA} / \mathrm{m}$. These values rule out pyrrhotite and confirm the predominance of greigite in lithostratigraphic Unit I of Hole U1501C. Using a rare-earth magnet on a slurry from Section 368-U1501A-1H-CC (PAL), greigite was separated and concentrated. The grains observed with an optical binocular microscope are subhedral, pale yellow, partially corroded metallic cubes $(\leq 10 \mu \mathrm{m}$ in length). These grains, documented with SEM (Figure F33), have physical sizes in the $2-10 \mu \mathrm{m}$ range, which corresponds to pseudosingle to multidomain magnetic grain sizes (Roberts et al., 2011). Overall, thermal demagnetization behaviors suggest that greigite dominates the $\mathrm{NRM}$, at least to $83 \mathrm{~m}$. However, the magnetic remanence remaining above $575^{\circ} \mathrm{C}$ (Figure F34) strongly suggests contributions from additional phases such as maghemite $\left(T_{\mathrm{C}} \approx 590^{\circ}-675^{\circ} \mathrm{C}\right.$; Tauxe, $2010)$ or hematite $\left(T_{\mathrm{C}} \approx 675^{\circ} \mathrm{C}\right.$; Tauxe, 2010). The NRM remaining above $575^{\circ} \mathrm{C}$ increases notably in the $50-85 \mathrm{~m}$ interval in Hole U1501C. The maximum field strength of in-line AF demagnetization used on the archive-half sections is limited because of the de-
Figure F32. Percentage of NRM loss between stepwise thermal demagnetization of NRM as a function of demagnetization temperature. Magnetization normalized to NRM (78 samples from Hole U1501C) carry the same statistical weight. Samples from Holes U1501A and U1501B were excluded to avoid statistically over representing the upper part of Unit l. Most magnetization is lost between $200^{\circ}$ and $300^{\circ} \mathrm{C}$, which shows that either greigite or pyrrhotite carry the NRM.

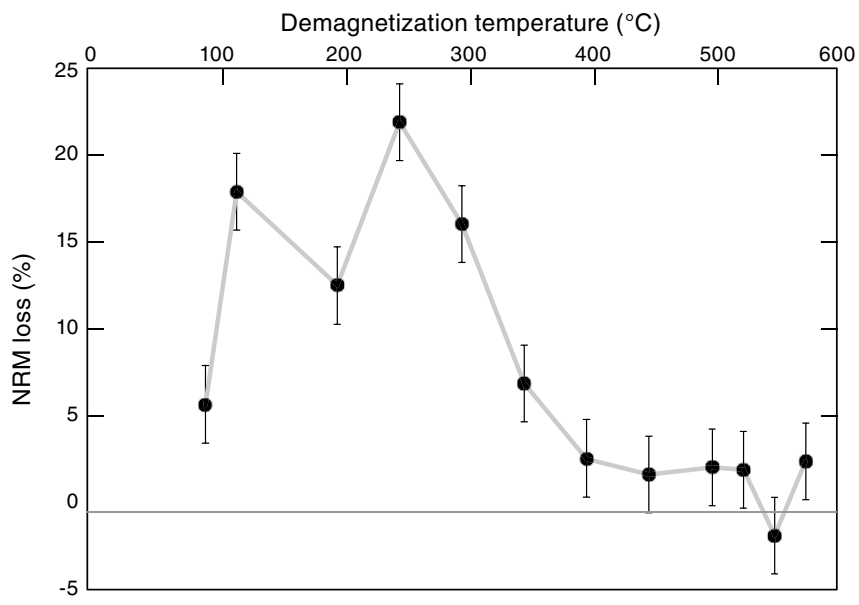

Table T11. Rock magnetic properties of representative samples, Hole U1501C. Download table in CSV format.

\begin{tabular}{cccc}
\hline $\begin{array}{c}\text { Core, section, } \\
\text { interval }(\mathrm{cm})\end{array}$ & $\operatorname{SIRM}_{2.3 \mathrm{~T}}(\mathrm{~A} / \mathrm{m})$ & $\mathrm{X}\left(10^{-6}\right)$, at $300 \mathrm{~A} / \mathrm{m}$ & $\mathrm{SIRM} / \mathrm{X}(\mathrm{kA} / \mathrm{m})$ \\
\hline $368-\mathrm{U} 1501 \mathrm{C}-$ & & & \\
$3 \mathrm{H}-7,30-32$ & 4.91 & 338 & 14.6 \\
$4 \mathrm{H}-1,36-38$ & 6.53 & 462 & 14.1 \\
$4 \mathrm{H}-5,27-29$ & 4.87 & 345 & 14.1 \\
$6 \mathrm{H}-3,26-28$ & 5.03 & 362 & 13.9 \\
$7 \mathrm{H}-3,30-32$ & 5.32 & 416 & 12.8 \\
$8 \mathrm{H}-2,90-92$ & 4.33 & 313 & 13.8 \\
\hline
\end{tabular}

structive nature of the treatments and our limited ability to measure weak magnetizations in the magnetically noisy shipboard environment. To evaluate the effectiveness of AF demagnetization of the NRM, experiments were performed on six discrete samples from Hole U1501C (Table T11). These experiments reveal the existence of a high-coercivity phase characterized by self-reversal behavior (Figure F35). This self-reversal behavior is typical of greigite (Krs et al., 1992; Horng et al., 1998) and has recently been reported in Pleistocene sediments of the South Yellow Sea (Liu et al., 2014).

Typical behaviors of demagnetization from the three complementary approaches are shown in Figure F36. AF demagnetization of these samples with in-line AF produces demagnetization paths that are easier to interpret than the results of discrete samples subjected to AF demagnetization. Both AF and thermal treatments on discrete samples effectively remove a steep low-temperature/lowcoercivity component, which represents the drilling overprint. However, thermal demagnetization is more effective at isolating ChRM, as evident by comparing results from twin samples collected from the same core and section (e.g., Figure F36C). The mean inclination gathered from the high-temperature component is $37.3^{\circ} \pm$ $6.6^{\circ}$, corresponding to a paleolatitude of $20.85^{\circ} \pm 3.3^{\circ}$ for Unit I (see Lithostratigraphy). 
Figure F33. SEM image of greigite cube ( $3 \mu \mathrm{m}$ length), Hole U1501A. Material was magnetically separated with a rare earth magnet from a slurry prepared from core catcher sample.

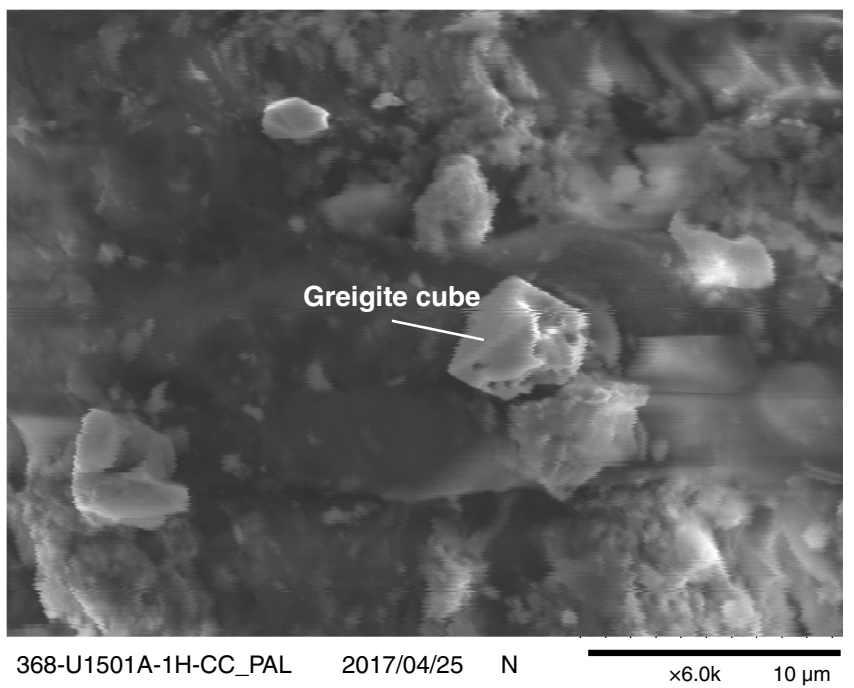

Many of the AF-demagnetized discrete samples reveal trends showing reversed or normal polarity in the last step of demagnetization $(50 \mathrm{mT})$.

Thermal demagnetization shows removal of a steep low-temperature normal component which is carried up to $300^{\circ} \mathrm{C}$.

\section{Magnetostratigraphy}

Inclination, declination, and intensity for Holes U1501AU1501D are reported in Figures F37, F38, and F39. We constructed the magnetostratigraphy of Site U1501 based on the polarity assigned to the archive-half cores and recognized polarity reversals in Hole U1501D (Figures F39, F40, F41; Tables T12, T13). We did not use data from Hole U1501C from $\sim 240 \mathrm{~m}$ to the bottom of the hole (Cores 35F through 62X) because a decrease in NRM moment hampers the determination of magnetic polarity.

Declinations from Holes U1501A and U1501B and Cores 368$\mathrm{U} 1501 \mathrm{C}-1 \mathrm{H}$ through $17 \mathrm{H}$ were corrected using the Icefield MI-5 core orientation tool (see Paleomagnetism in the Expedition 367/368 methods chapter [Sun et al., 2018a]). In Holes U1501C and U1501D, the interpretation of polarity deeper than $156.8 \mathrm{~m}$ is based only on the inclination data because the $\mathrm{XCB}$ and $\mathrm{RCB}$ coring processes disturb the geographic core orientation. Our interpretations of inclination are based on directions derived from the raw moments measured by the SRM at $25 \mathrm{mT}$ and from the corroborative evidence from AF demagnetization of discrete samples.

We then correlated the magnetostratigraphic data of Site U1501 to the standard timescale (Ogg et al., 2016) and plotted them along with the tie points from the microfossil ages from shipboard paleontologists (Figures F40, F41). The paleomagnetic and paleontological age constraints match well over most of the section. A succession of eight normal and five reversed intervals was recognized in Hole U1501D (Table T13; Figure F39). The lack of fossils in Unit III prevents correlation of magnetostratigraphic features ( $\mathrm{n} 1$ to $\mathrm{n} 8$ in Figure F39) to the geologic timescale. The apparently long $\mathrm{n} 8$ interval ( $\sim 37.45 \mathrm{~m}$ thick) may only represent a relatively short duration $(0.37 \mathrm{My})$ if the sedimentation rate was high $(\sim 100 \mathrm{~mm} / \mathrm{ky})$ at that time.
Figure F34. Variation of percentage of NRM left above $575^{\circ} \mathrm{C}$, upper part of Hole U1501C $(1 \mathrm{H}$ through $9 \mathrm{H})$. Note the significant increase in the percentage below $60 \mathrm{~m}$, which suggests an increasing contribution of maghemite or hematite.

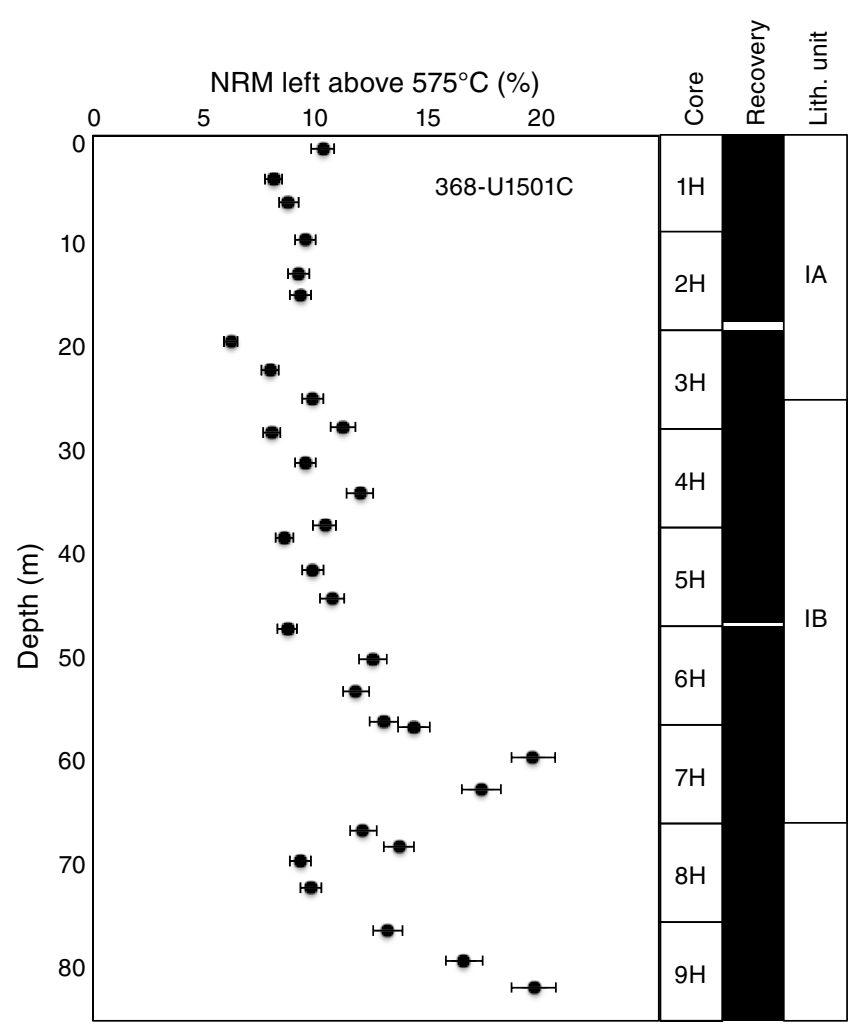

Figure F35. Magnetization normalized to NRM as a function of AF demagnetization, Hole U1501C. This behavior shows initially low coercivity below 30 $\mathrm{mT}$ followed by coercivity inversion (or plateau), generally attributed to magnetic self-reversal of greigite (e.g., Krs et al., 1992; Horng et al., 1998). Complete demagnetization requires AF fields $>100 \mathrm{mT}$.

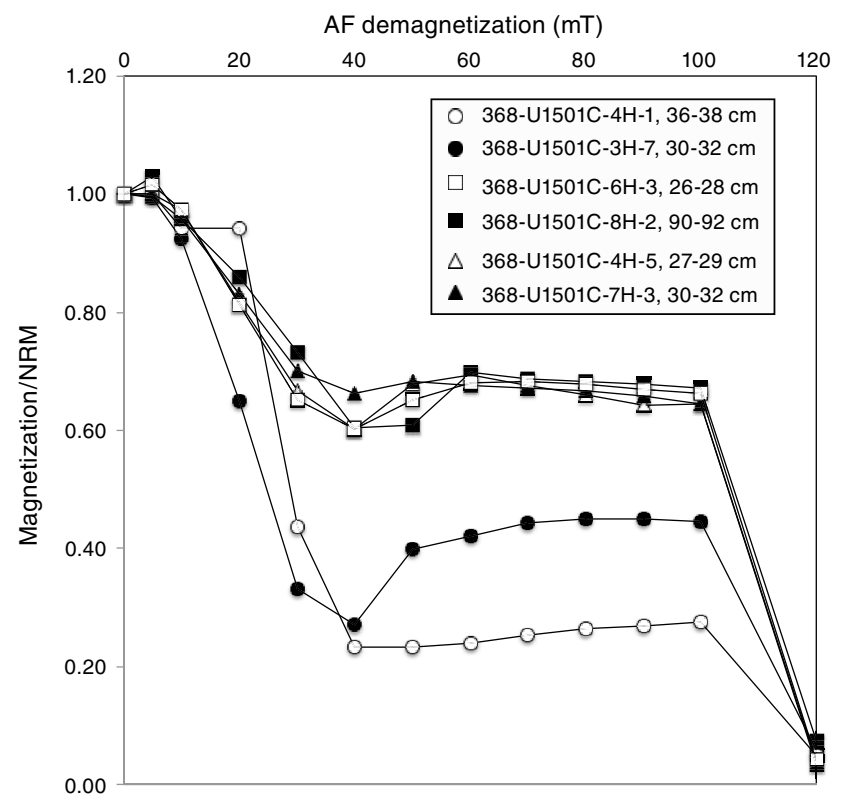


Figure F36. Demagnetization plots of (A, D, E, G, H) archive-half sections and (B, C, F, I) discrete samples, Holes U1501C and U1501D. A, B, D, E, F, G, H: AF demagnetized; $C$, I: thermally demagnetized. Zijderveld plots: solid squares $=$ declination, open squares $=$ inclination. Stereographic plots: solid squares $=$ positive (down) inclination, open squares = negative (up) inclination. Calculated ChRM (blue line; red squares = measurements used in calculation) using PCA are in good agreement for samples coming from same section and subjected to different treatments. Unit I: (A) reversed polarity, (B) normal polarity but with last step indicating a tendency to reversal, (C) reversed polarity. Unit II: (D) normal polarity, (E) reversed polarity, (F) normal polarity. Unit III: (G) normal polarity, (H) reversed polarity, (I) normal polarity.

A $368-\mathrm{U} 1501 \mathrm{C}-4 \mathrm{H}-7 \mathrm{~A}, 17.5 \mathrm{~cm}$ Dec $99.34^{\circ} / \mathrm{lnc}-23.71^{\circ}$

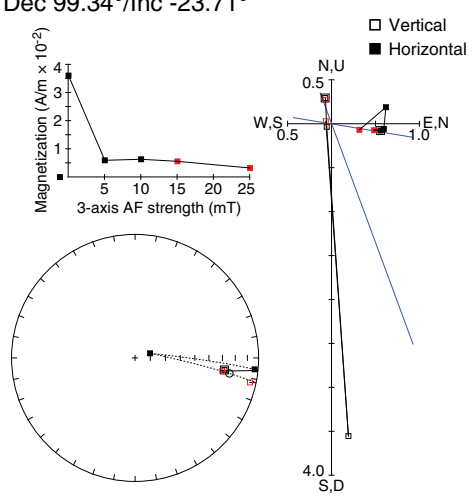

D 368-U1501D-17R-4A, $582.05 \mathrm{~m}$
$\begin{aligned} & \text { Dec 228.62//lnc 61.24 } \\ & \text { a Horizontal }\end{aligned}$

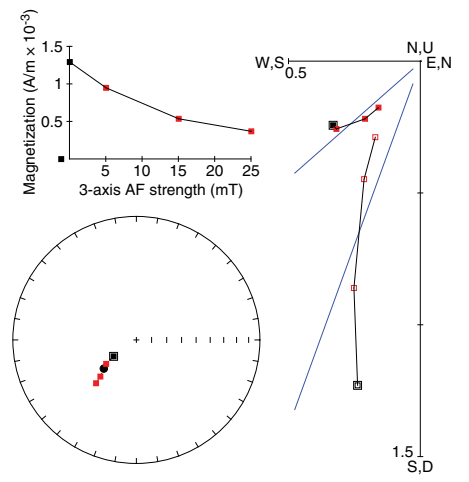

G 368-U1501D-21R-1A, $610.7 \mathrm{~m}$

Dec $0.87^{\circ} /$ Inc $53.34^{\circ}$

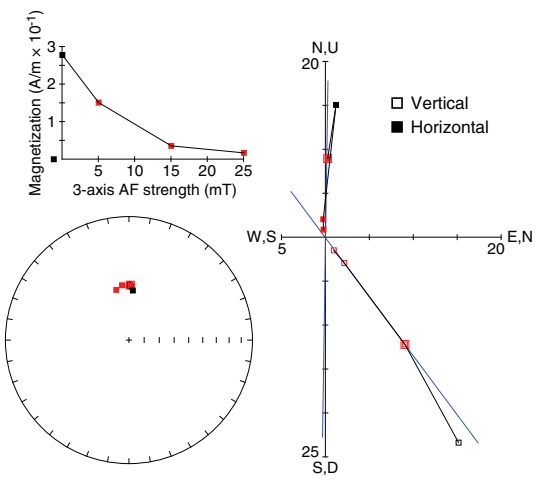

B 368-U1501C-4H-7W, $41 \mathrm{~cm}$ Dec $116.14^{\circ} / \mathrm{lnc} 34.80^{\circ}$

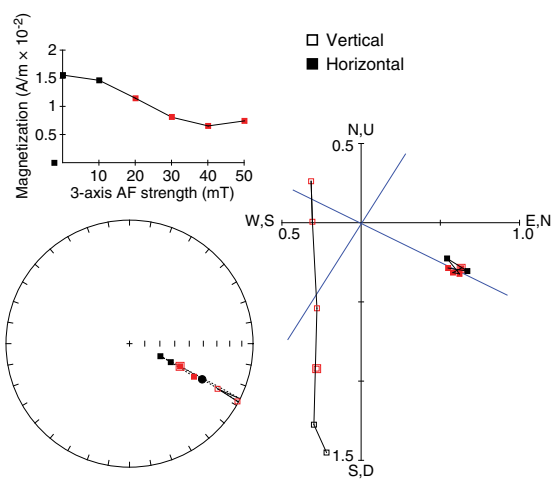

E 368-U1501D-15R-3A, $561.175 \mathrm{~m}$ Dec $106.08^{\circ} / \mathrm{Inc}-46.16^{\circ}$

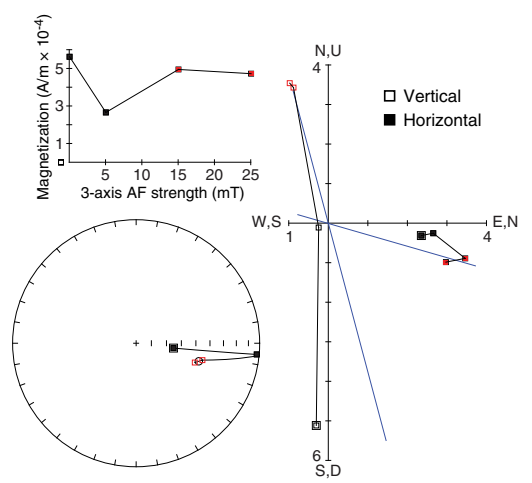

H 368-U1501D-20R-3A, $610.045 \mathrm{~m}$ Dec $355.54^{\circ} /$ Inc $-65.46^{\circ}$
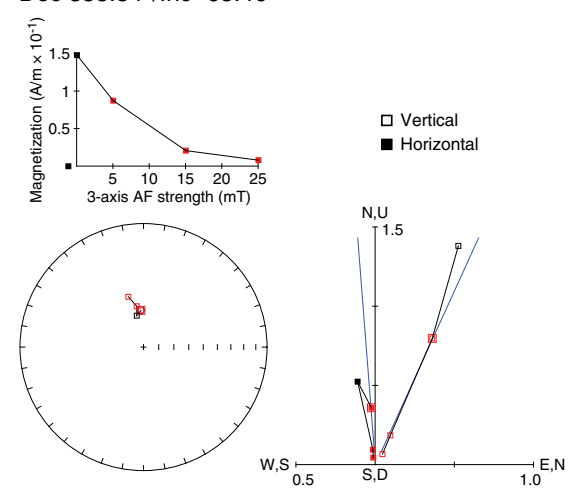

C 368-U1501C-4H-7W, $45 \mathrm{~cm}$ Dec $148.58^{\circ} / \mathrm{lnc}-10.32^{\circ}$
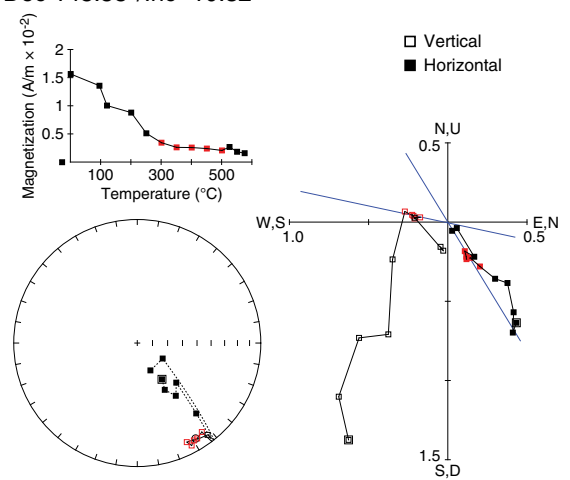

F 368-U1501D-17R-2W, $58 \mathrm{~cm}$ Dec $147.35^{\circ} /$ Inc $52.79^{\circ}$
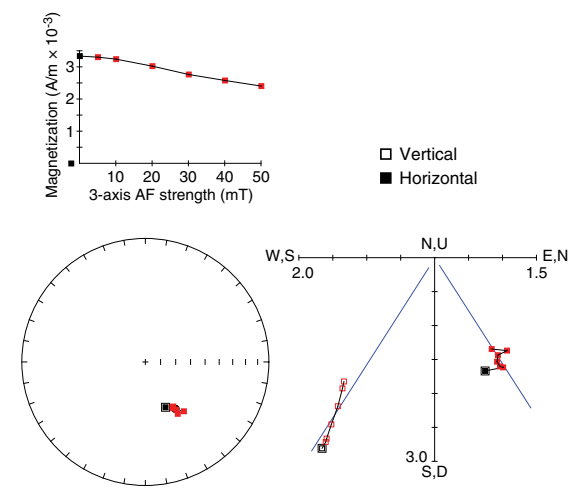

I 368-U1501D-22R-3W, $95 \mathrm{~cm}$ 口 Vertical
Dec $176.16^{\circ} / \mathrm{Inc} 44.86^{\circ}$
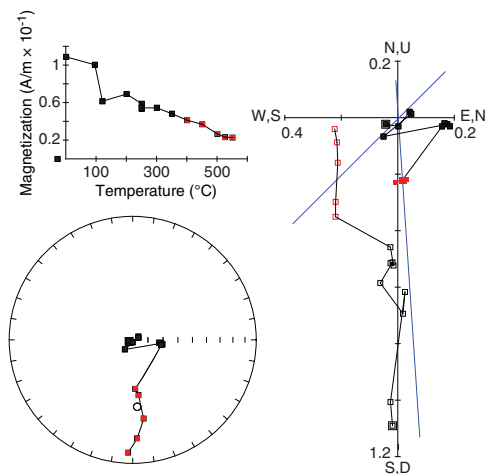

Based on both inclination and declination, we placed the boundary between the Brunhes and Matuyama Chrons at $\sim 24 \mathrm{~m}$ in Hole U1501C. Based on our shipboard paleomagnetic age model, the middle/early Pleistocene boundary $(0.78 \mathrm{Ma})$ is at $\sim 24 \mathrm{~m}$, the Pleistocene/ Pliocene (2.58 Ma) boundary is at $\sim 62 \mathrm{~m}$, and the Pliocene/ Miocene boundary (5.33 Ma) is at $\sim 90 \mathrm{~m}$ (Table T12). 
Figure F37. Magnetic measurements, Holes (A) U1501A and (B) U1501B. Inclination was used to determine polarity. AFD = AF demagnetization, TD = thermal demagnetization. Discrete samples are yellow and green.

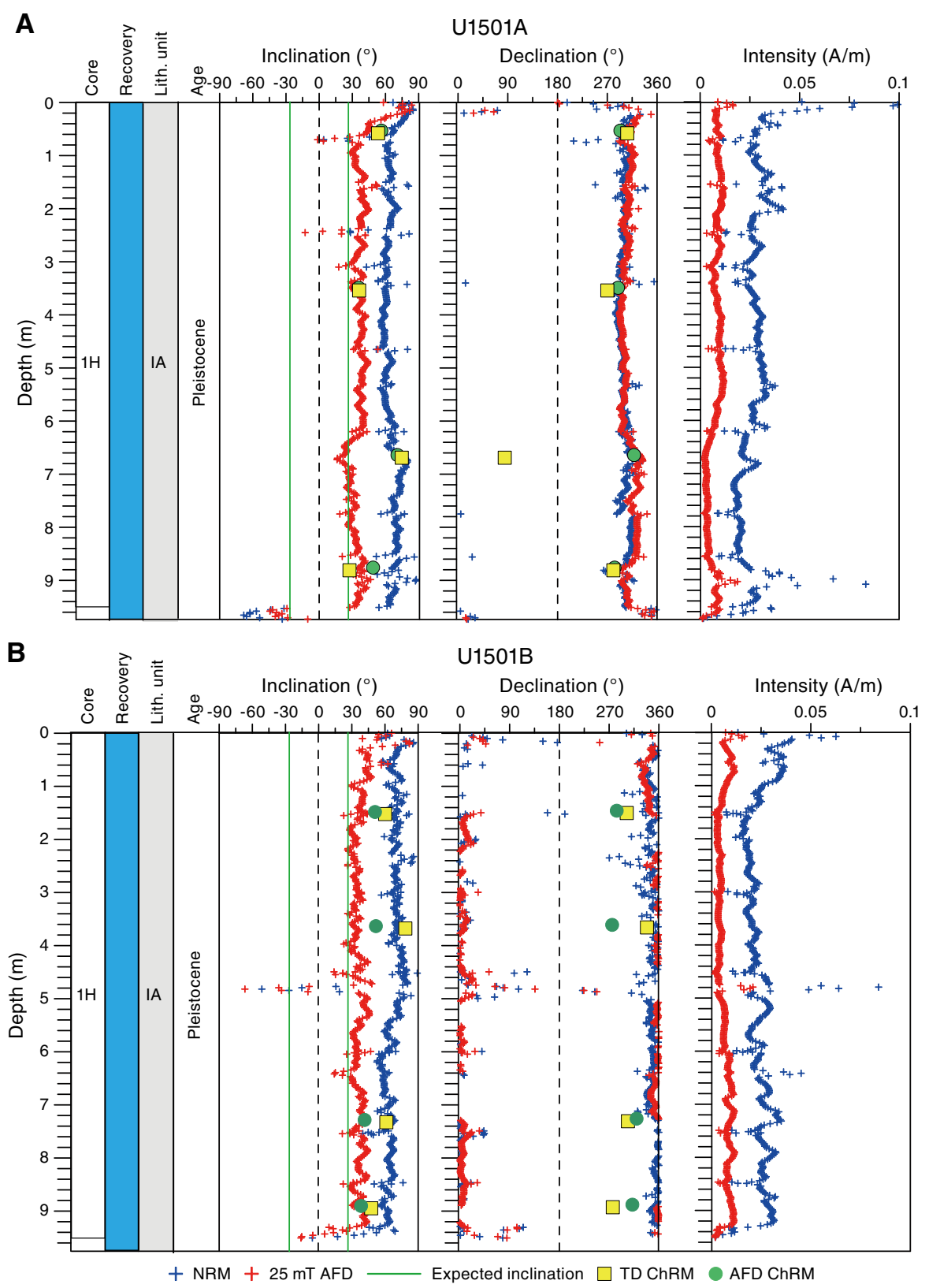


Figure F38. Magnetic measurements, Hole U1501C. Inclination was used to determine polarity. Discrete samples are yellow and green.

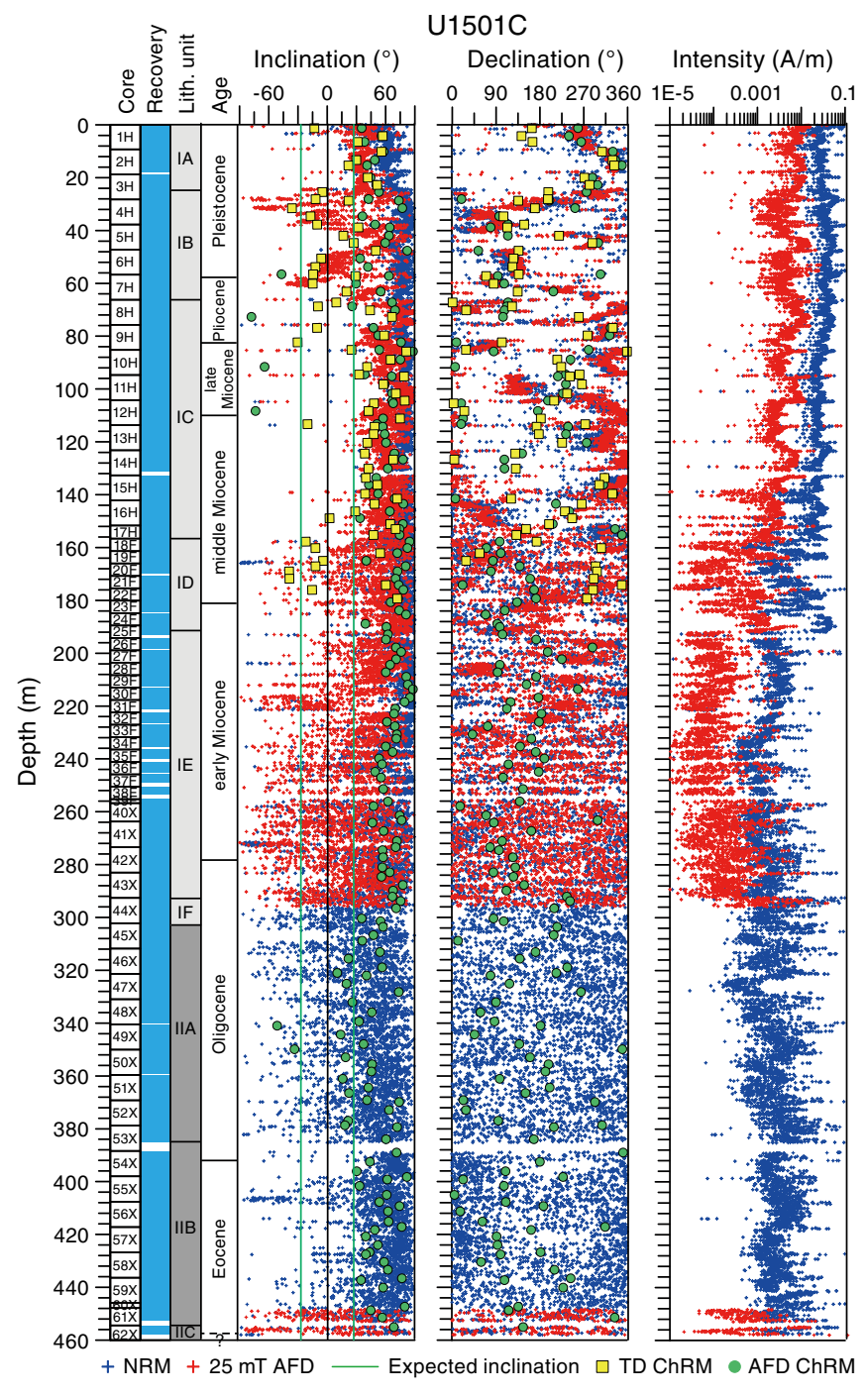


Figure F39. Magnetic measurements, Hole U1501D. Inclination was used to determine polarity. Magnetostratigraphic features are referred to as n1, etc., in a sequential manner for convenience and have no bearing on chrons. GTS2016 = geomagnetic polarity timescale of Ogg et al. (2016). Green circles = discrete samples.

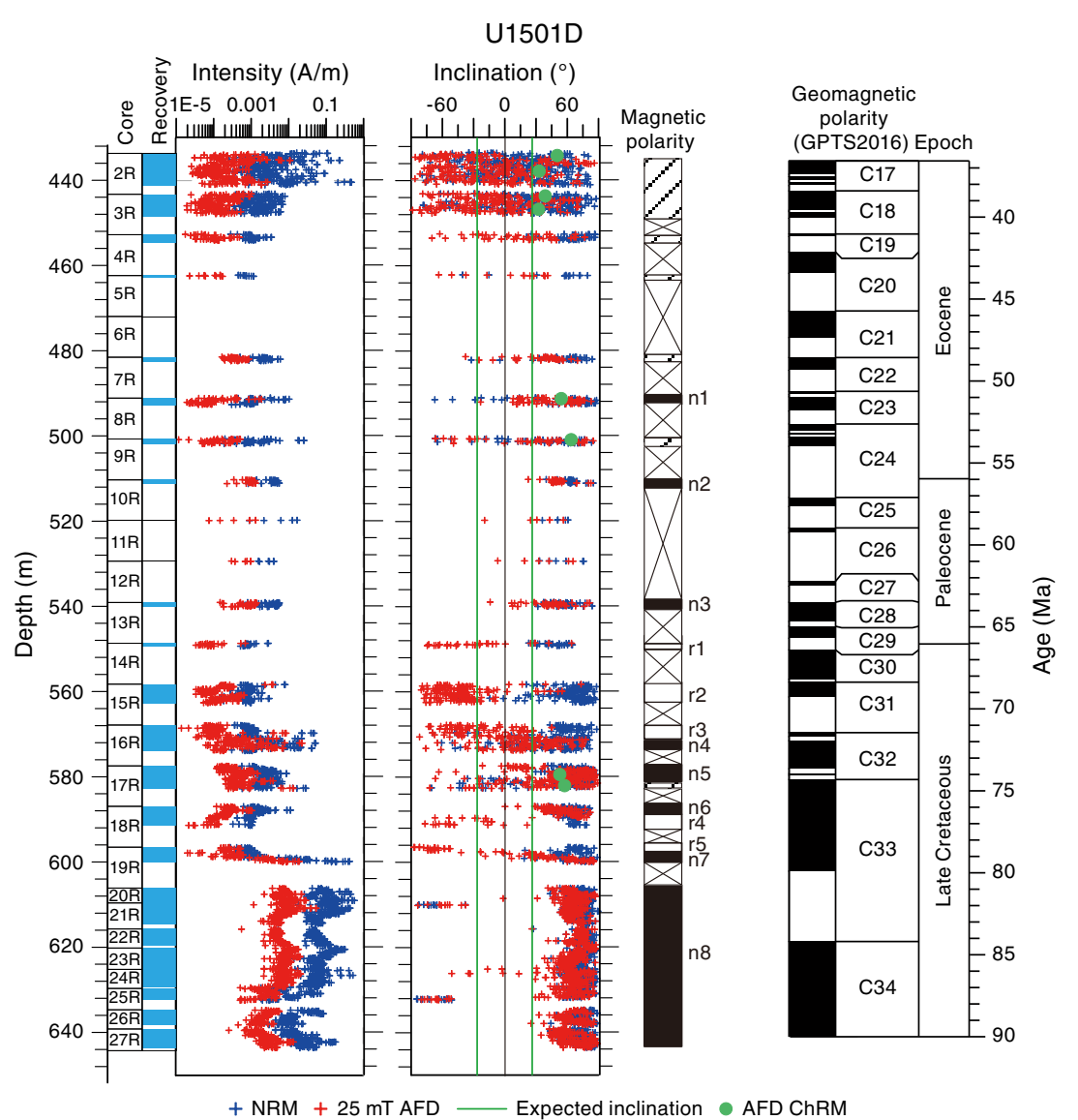

Normal polarity $\square$ Reversed polarity $Z$ Unidentified $\$ No recovery 
Figure F40. Magnetic measurements and correlation to magnetostratigraphy (368-U1501C-1H through 17H). Age-depth model constructed from shipboard paleomagnetic analysis. Magnetostratigraphy converted to time and plotted against standard geologic timescale (GPTS2016; Ogg et al., 2016). Magnetostratigraphic features are referred to as $\mathrm{n} 1$, etc., in a sequential manner for convenience and have no bearing on chrons. B/M = Brunhes/Matuyama Chron boundary, $\mathrm{M} / \mathrm{G}=$ Matuyama/Gauss Chron boundary. Discrete samples are yellow and green.
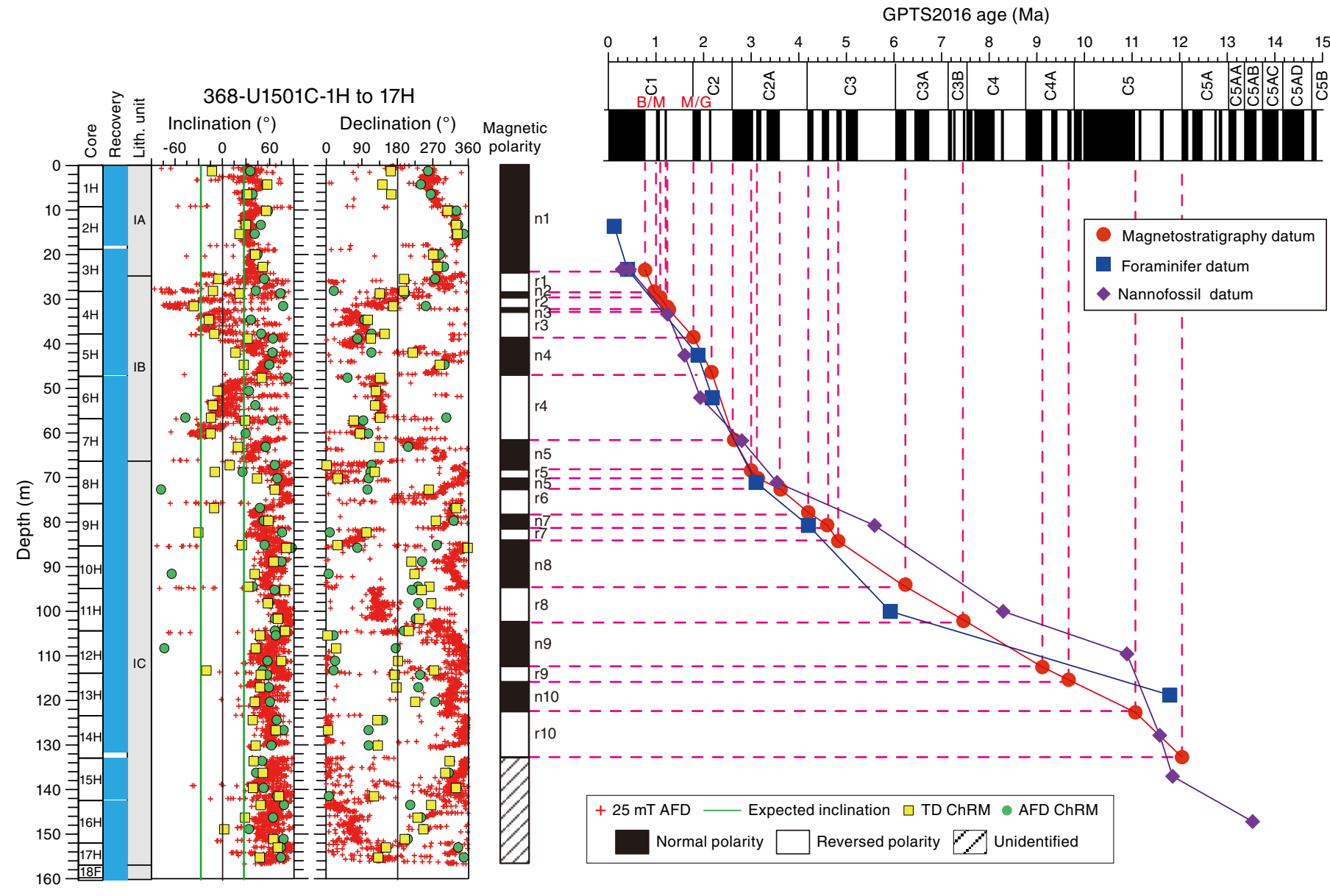
Figure F41. Magnetic measurements and correlation to magnetostratigraphy (U1501C-18F through 40X-2). Age-depth model constructed from shipboard paleomagnetic analysis. Magnetostratigraphy converted to time and plotted against standard geologic timescale (GPTS2016; Ogg et al., 2016). Magnetostratigraphic features are referred to as $\mathrm{n} 1$, etc., in a sequential manner for convenience and have no bearing on chrons. Discrete samples are yellow and green.

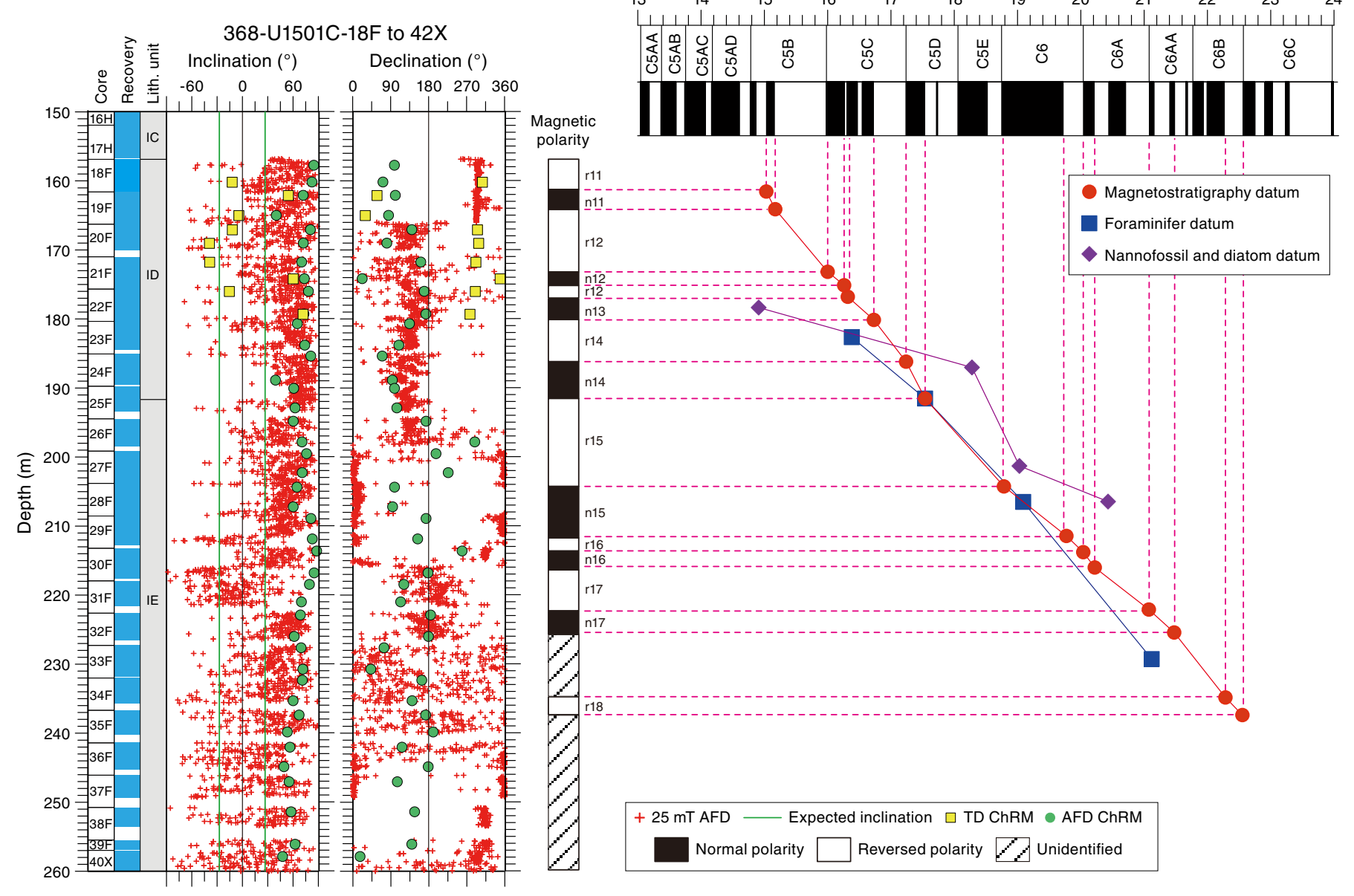

Table T12. Paleomagnetic age datums, Hole U1501C. Download table in CSV format.

\begin{tabular}{lcc}
\hline \multicolumn{1}{c}{ Polarity chron } & $\begin{array}{c}\text { Age of chron base } \\
(\mathrm{M})\end{array}$ & $\begin{array}{c}\text { Depth CSF-A } \\
(\mathrm{m})\end{array}$ \\
\hline C1n (Brunhes) & 0.773 & 24.00 \\
C1r.1r & 1.008 & 28.40 \\
C1r.1n (Jaramillo) & 1.076 & 30.00 \\
C1r.2r & 1.189 & 32.10 \\
C1r.2n (Cobb Mountain) & 1.221 & 33.05 \\
C1r.3r & 1.775 & 38.50 \\
C2r.1n (Feni) & 2.155 & 47.00 \\
C2r.2r & 2.61 & 61.90 \\
C2An.1n & 3.032 & 68.05 \\
C2An.1r (Keana) & 3.116 & 70.10 \\
C2An.3n & 3.596 & 72.80 \\
C2Ar & 4.187 & 78.20 \\
C3n.2n (Nunivak) & 4.631 & 81.70 \\
C3n.2r & 4.799 & 84.20 \\
C3An.1n & 6.252 & 91.60 \\
C3Br.2r & 7.454 & 102.40 \\
C4An & 9.105 & 112.45 \\
C5n.2n & 11.056 & 122.35
\end{tabular}

\begin{tabular}{lcc}
\hline \multicolumn{1}{c}{ Polarity chron } & $\begin{array}{c}\text { Age of chron base } \\
(\mathrm{Ma})\end{array}$ & $\begin{array}{c}\text { Depth CSF-A } \\
(\mathrm{m})\end{array}$ \\
\hline C5Bn.1r & 15.032 & 161.40 \\
C5Bn.2n & 15.16 & 164.20 \\
C5Br & 15.974 & 173.14 \\
C5Cn.1n & 16.268 & 174.80 \\
C5Cn.1r & 16.303 & 176.12 \\
C5Cn.3n & 16.721 & 180.04 \\
C5Cr & 17.235 & 186.06 \\
C5Dn & 17.533 & 191.50 \\
C5Er & 18.748 & 204.25 \\
C6n & 19.722 & 211.50 \\
C6r & 20.04 & 213.50 \\
C6An.1n & 20.213 & 216.24 \\
C6Ar & 21.083 & 222.25 \\
C6AAr.1n & 21.483 & 225.52 \\
C6Bn.2n & 22.268 & 234.97 \\
C6Br & 22.564 & 237.08 \\
\hline
\end{tabular}


Table T13. Interpreted possible magnetic polarity sequence, Hole U1501D. Download table in CSV format.

\begin{tabular}{lcc}
\hline \multirow{2}{*}{$\begin{array}{c}\text { Possible magnetic } \\
\text { polarity }\end{array}$} & \multicolumn{2}{c}{ Depth CSF-A $(\mathrm{m})$} \\
\cline { 2 - 3 } n1 & Upper boundary & Lower boundary \\
n2 & 491.000 & 492.285 \\
n3 & 510.200 & 511.125 \\
r1 & 539.000 & 539.925 \\
r2 & 548.700 & 549.275 \\
r3 & 558.275 & 562.575 \\
n4 & 564.000 & 570.725 \\
n5 & 570.725 & 573.805 \\
n6 & 577.400 & 582.505 \\
r4 & 586.900 & 589.590 \\
r5 & 589.625 & 591.355 \\
n7 & 596.500 & 597.860 \\
n8 & 598.805 & 599.940 \\
\end{tabular}

\section{Geochemistry}

Headspace gas concentrations were below detection due to low TOC contents $<0.25 \mathrm{wt} \%$ and low levels of thermal alteration within underlying units. The bulk sediment geochemistry was controlled by lithology. High calcium carbonate content in lithostratigraphic Unit I reflects its high biogenic carbonate content. TOC and sulfur are mostly low in Unit I, with higher sulfur concentrations observed in lithostratigraphic Unit II. The low TOC concentrations in much of Unit I likely reflect poor preservation under aerobic conditions. The interstitial water concentration depth profiles show atypical redox zones for marine sediments with rates of sulfate reduction appearing to be inhibited, much as methanogenesis has likely been inhibited at this site. Sulfate reduction is more pronounced in Unit II $(>300 \mathrm{~m})$, and within this interval there is also heavy pyritization. Raman spectroscopy was applied shipboard to organic materials and indicates a mild thermal history for Units I and II. Surface-enhanced Raman spectroscopy yielded Raman bands diagnostic of asphaltene within the sediments of Unit I.

\section{Headspace gas}

Headspace gas samples were taken at a frequency of one sample per core or per $10 \mathrm{~m}$ of drilling advance for routine safety monitoring. Where possible, samples were collected from sections adjacent to interstitial water samples. At no point did hydrocarbon gas levels exceed a 12 ppmv detection limit-a limit corresponding to background values in air. Methane was detected in standard reference materials and within a paleomagnetism sample obtained from the core catcher of Core 368-U1501C-62X that evidenced drilling disturbance (frictional heating induced by rotation). A typical safety gas chromatogram is shown in Figure F42, in which hydrocarbons up to propane $\left(\mathrm{C}_{4} \mathrm{H}_{10}\right)$ can be seen in the drilling-disturbed sample (propane is the highest carbon number that is quantified by the method used). Also shown are data for the analysis of a paleomagnetism sample obtained from the core catcher that was altered by drilling disturbance and contains light hydrocarbon gases. Analytical methods were capable of detecting light hydrocarbon gases, but none were present at significantly high concentrations within safety gas samples. Traces of propene were also detected, particularly from headspace samples collected close to the core liner and from RCB cores.
Figure F42. Gas chromatograms showing low levels of methane present in headspace samples, Hole U1501C. Detection of hydrocarbon gases in a drilling-disturbed sample obtained from a core catcher is shown for comparison. Relatively high proportions of ethene are consistent with generation of hydrocarbons by frictionally induced flash pyrolysis.

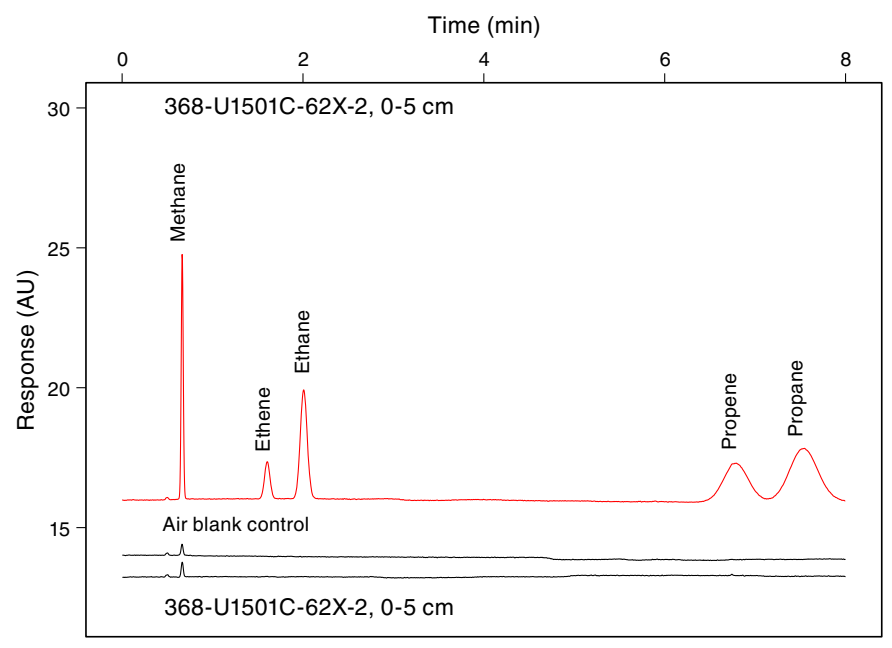

\section{Bulk sediment organic geochemistry}

Bulk sediment organic geochemical parameters are presented by depth in Figure F43 and Table T14 and cross-plotted by unit in Figure F44.

\section{Lithostratigraphic Unit I}

Sediments from the uppermost $30 \mathrm{~m}$ of lithostratigraphic Unit I (seafloor to Core 368-U1501C-5H) generally have high TOC and low carbonate contents. The top of the section to $\sim 25 \mathrm{~m}$ has low but measurable sulfur contents. Otherwise, lithostratigraphic Subunits IB-IF have very low sulfur values. This is distinct from the underlying members of Unit I that have an average carbonate content of $\sim 40 \mathrm{wt} \%$ and low TOC, typically $<0.25 \mathrm{wt} \%$. Given the fossiliferous nature of the lithologies (nannofossil ooze with foraminifers), it is unlikely that these carbon results represent low levels of biological productivity. More likely, they represent poor preservation of organic matter, which is typical of accumulation under aerobic rather than anaerobic conditions (Demaison and Moore, 1980). The preservation of sulfur in sediments is biologically mediated by sulfate reduction to form sulfide, which in turn forms pyrite (Berner and Raiswell, 1984). Under aerobic conditions, this process is inhibited and would not occur as readily, although organic matter starvation also inhibits sulfate reduction because organic matter forms part of the vital redox couple for sulfate reduction. Whatever the cause, dissolved sulfate concentrations within interstitial water, as described later, did not decline markedly within Subunits IB-IF, supporting the notion that TS levels are low because sulfur has not been reduced during early diagenesis and fixed as pyrite. The instances of very high TOC/total nitrogen $(\mathrm{TN})$ ratios $(>10)$ may reflect an autochthonous input of terrestrial-derived organic matter to the sediments but may also be produced by a lower detection limit for organic carbon than for nitrogen (Hedges et al. 1988).

\section{Lithostratigraphic Unit II}

Lithologies within lithostratigraphic Unit II include both high and low TOC members that likely reflect sandy and mud-rich litho- 
Figure F43. (A) Methane, (B) TOC and TS, and (C) carbon/nitrogen ratio and carbonate.
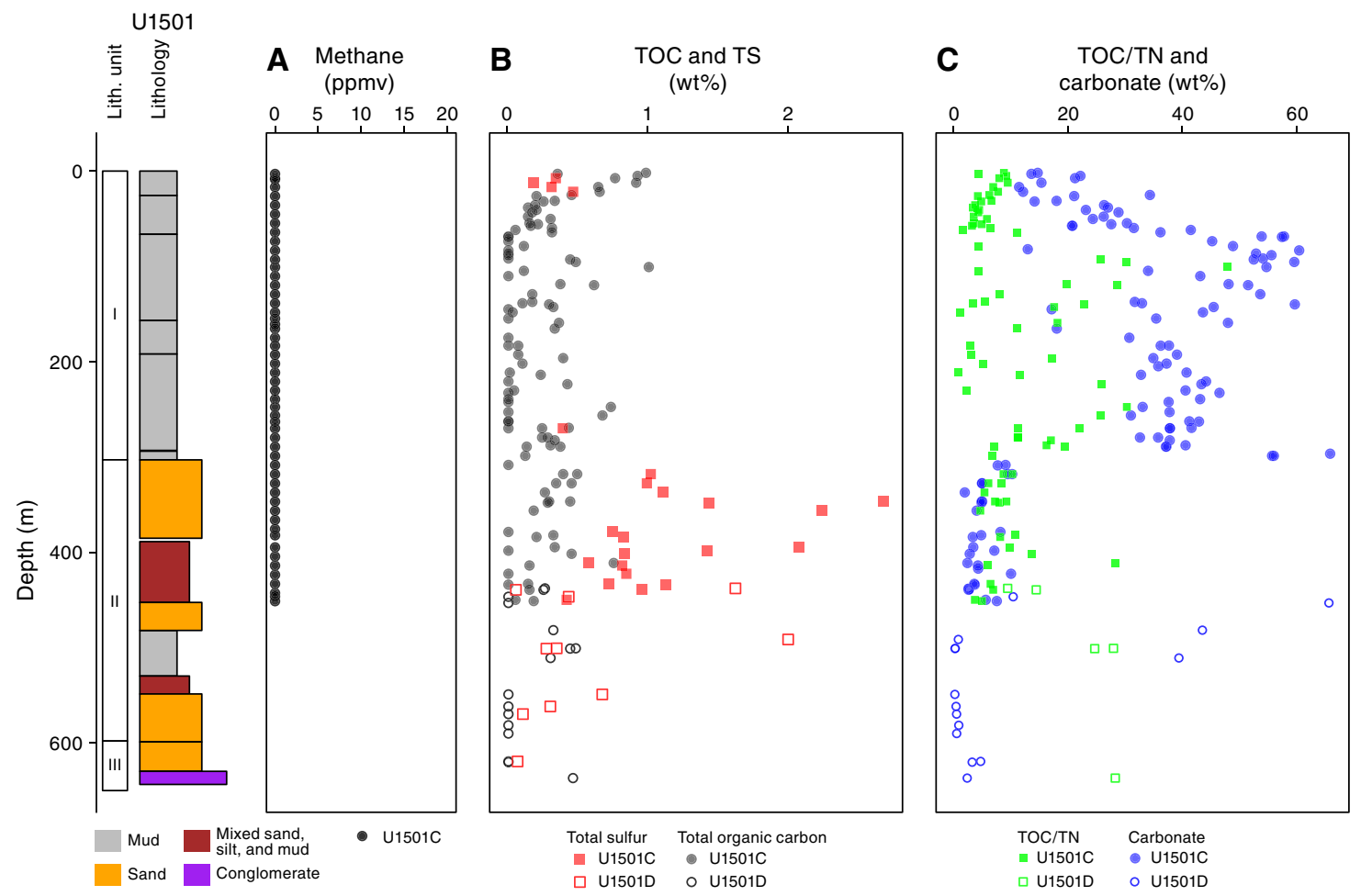

Table T14. Carbon, nitrogen, and sulfur, Holes U1501C and U1501D. View table in PDF format. Download table in CSV format.

Figure F44. Crossplot of organic geochemical parameters: carbonate vs. carbon/nitrogen ratio and TS vs. TOC. Black circles = lithostratigraphic Subunit IA, open triangles = Subunits IB-IF, crosses = Unit II, green circles = Unit III.
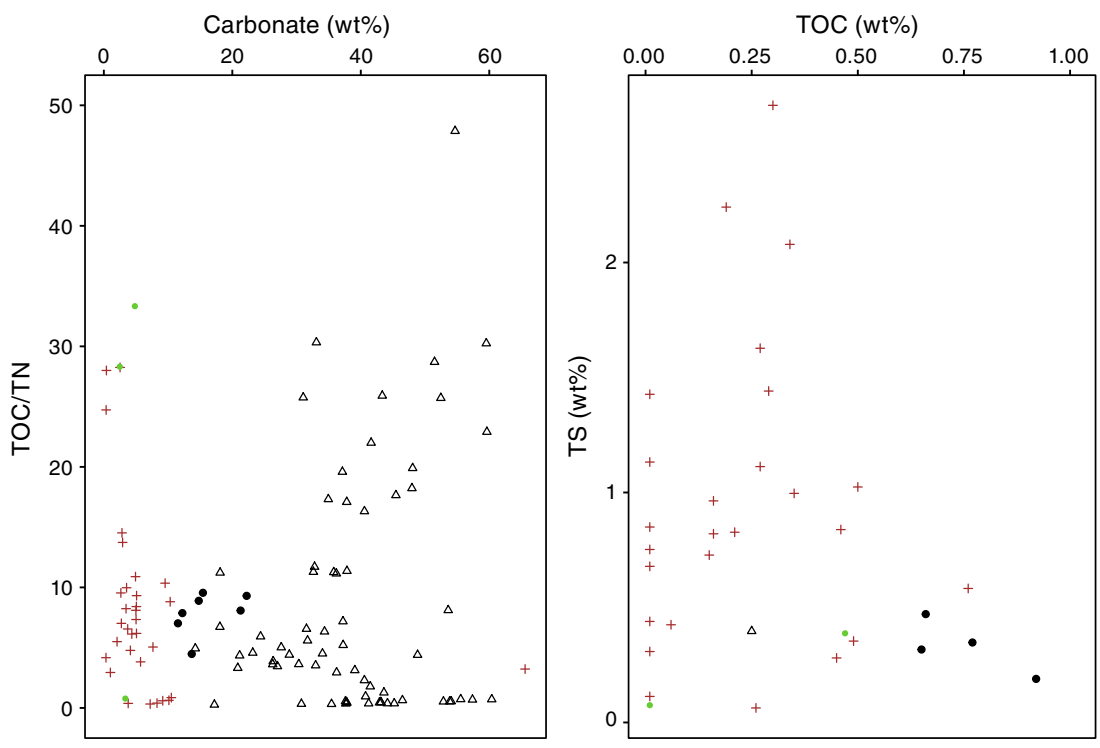

logies. The highest TOC values have the highest TOC/TN ratio, consistent with organic carbon being derived from terrestrial organic matter (Hedges et al., 1988). This unit also has high sulfur content, likely reflecting the fixation of interstitial water sulfate as sulfide that becomes incorporated within sulfide minerals during diagenesis (Raiswell and Berner, 1984). The unit has low carbonate contents relative to Unit I, but overall an 8-10 wt\% carbonate con- tent is still significant and must represent either a bioclastic or authigenic component.

\section{Lithostratigraphic Unit III}

Only a few lithologies within lithostratigraphic Unit III were analyzed (three samples in all). A TOC content of $0.5 \mathrm{wt} \%$ was obtained for gray mudstone, but otherwise Unit III sediments have 
very low TOC and carbonate contents. The sulfur content of $<0.5$ $\mathrm{wt} \%$ is low but higher than might be expected given the unit's lithologic associations (gravel) and when compared to Unit I (see Lithostratigraphy).

\section{Raman and surface-enhanced Raman spectroscopy}

Conventional Raman spectroscopy was applied to organic materials, including samples of amber, ash-rich lignite, and bitumen. For reference purposes, they are compared to a sample of Midlothian bituminous coal from the Midlothian coalfields (Scotland) and a sample of pre-oil-window oil-shale from the Brora Coal Member (Caithness, Scotland). Raman spectra are shown in Figure F45. Raman spectra obtained from solid carbon-rich fossil organic matter typically have two broad composite bands (or peaks). The first is centered at $1460 \mathrm{~cm}^{-1}$, is relatively broad and wide, and is termed the disordered band (D-peak). Another band at $1600 \mathrm{~cm}^{-1}$ is produced by vibrational modes generated by aromatic sheets with a graphite-like structural ordering (Pasteris and Wopenka, 2003) and is termed the graphite $(\mathrm{G})$ or ordered $(\mathrm{O})$ peak.

Fluorescence dominates the spectra obtained for the amber sample (368-U1501C-61X-1, $70 \mathrm{~cm})$, with no clear band distinguished at 1460 or $1600 \mathrm{~cm}^{-1}$, although the broad band observed around $1550 \mathrm{~cm}^{-1}$ likely derives from the ordering of $\pi$-bonded aromatic sheets with graphite-like structures. A D-peak is also present, but is so broad it cannot be reasonably interpreted. Thus, the sample can be shown to contain organic carbon, but beyond this no other information can be obtained. Relative to the high molecular weight aromatic compounds within humic organic macerals or kerogen, amber comprises plant resins that are highly aliphatic, lack strong aromatic cores, and fluoresce strongly. These qualities make these materials poorly suited for analysis by Raman spectroscopy using a $532 \mathrm{~nm}$ light source.

The sample of lignite (light brown streak, no cleats, and partial humification; Sample 368-U1501D-9R-1, $78 \mathrm{~cm}$ ) yielded broad D and $G$ bands characteristic of levels of thermal maturation typical of brown coal (preoil and gas generation) and levels of thermal alteration that indicate heating at temperatures $<40^{\circ} \mathrm{C}$.

In most cases, the bitumen impregnating a sandstone clast from Section 368-U1501D-27R-1, 10-15 cm, yielded fluorescence only, but Raman spectra were obtained from a solvent-insoluble component present on the clast's exterior and within a fracture. The D band for these spectra was shrouded by fluorescence, but a G peak could be observed, and the Raman shift was notably high (equal to or greater than that of the coal, $\sim 1600 \mathrm{~cm}^{-1}$ ), possibly indicating a higher level of thermal maturity than observed for the lignite. This higher level would be consistent with the insolubility of the bitumen in solvent.

Surface-enhanced Raman spectroscopy detected $0.2-2$ ng asphaltene/g sediment in lithostratigraphic Units I and II. Detection required deconvolution of surface-enhanced Raman spectra (Figure F46). Primarily, two components were considered: solvent extracts of sedimentary organic matter (SOM) that exhibited relatively narrow Raman bands at shifts of 1310,1448 , and $1650 \mathrm{~cm}^{-1}$ and asphaltene that exhibited broad Raman bands at 1380 and 1575-1585 $\mathrm{cm}^{-1}$ (Alabi et al., 2015). A small Raman band at $\sim 1522 \mathrm{~cm}^{-1}$ was often left as a residual. The two broad Raman bands are at positions consistent with previous studies of asphaltene and are similar to the $\mathrm{D}$ and $\mathrm{G}$ bands of solid carbonaceous materials, whereas the band at $\sim 1522 \mathrm{~cm}^{-1}$ is a position, based on previous surface-enhanced Raman scattering studies, that likely corresponds to carotenoids (Wil-
Figure F45. Raman spectra of carbonaceous materials collected from reference materials and Holes U1501C and U1501D. AU = arbitrary units.

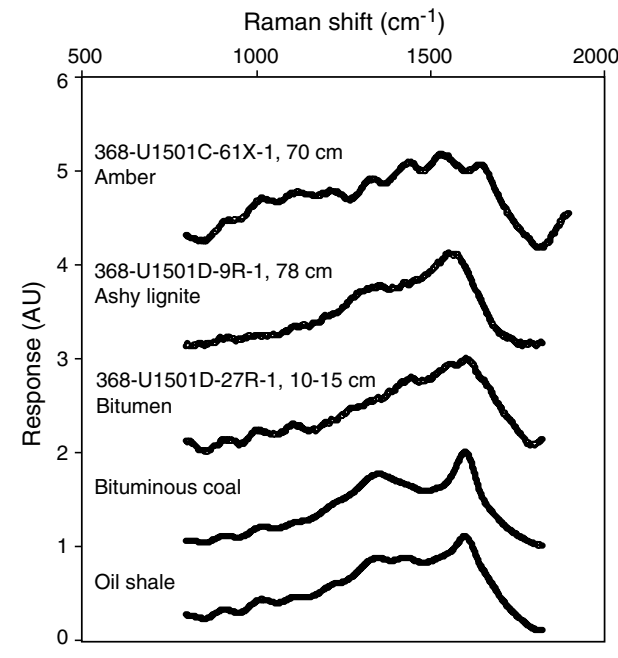

son et al., 2007), which are also a likely component of marine SOM. The detection of surface-enhanced Raman scattering bands diagnostic for asphaltene and thereby residual petroleum (asphaltene is the most resistant component of petroleum and bitumen and accumulates as residues) is important given the context of the SOM. There is no evidence of recent petroleum migration at Site U1501, and indeed headspace hydrocarbon gases remained below detection. The single instance of bitumen was a highly thermally matured solid component, unlikely to have migrated in recent geological history.

\section{Interstitial water chemistry}

Shipboard analyses were performed on interstitial water squeezed from $5-15 \mathrm{~cm}$ long whole-round sediment samples from Hole U1501C. For Cores $1 \mathrm{H}$ through $10 \mathrm{H}, 5 \mathrm{~cm}$ long interstitial water samples were squeezed and yielded $>40 \mathrm{~mL}$ of interstitial water per sample. For Cores $11 \mathrm{H}$ through $37 \mathrm{~F}, 10 \mathrm{~cm}$ long whole-round sediment cores were squeezed and yielded $\sim 30 \mathrm{~mL}$ of interstitial water. For Cores 39F through 61X, $15 \mathrm{~cm}$ long whole-round interstitial water samples yielded $<15 \mathrm{~mL}$ of interstitial water per sample. In Hole U1501D, only one sample from Core 2R yielded water on squeezing and then only at a maximum pressure of 30,000 lb for $6 \mathrm{~h}$.

Interstitial water geochemical parameters are listed in Table T15 and presented by depth in Figures F47 and F48.

We defined four geochemical interstitial water zones at Site U1501 based on the variation of geochemical parameters (listed in Table T15). Interstitial water Zone 1 (interval 368-U1501C-1H-2, $0-5 \mathrm{~cm}$, through $2 \mathrm{H}-5,0-5 \mathrm{~cm}$ ) comprises samples obtained close to the mudline (sediment/water interface). Within this interval, maximum sulfate, alkalinity, phosphate, ammonium, boron, silica, lithium, and manganese concentrations are likely related to degradation of organic matter. In interstitial water Zone 2 (interval $3 \mathrm{H}-2$, $0-5 \mathrm{~cm}$, through $43 \mathrm{X}-4,0-15 \mathrm{~cm}$ ), sulfate slightly decreases and alkalinity is buffered by high carbonate concentrations within foraminifer-rich oozes. Atypically for this marine setting ( $\mathrm{Li}$ et al., 2015a), in which sulfate reduction is prevalent in marine sediments, diffusion processes dominate the sulfate profile. Decreasing $\mathrm{K}$ and $\mathrm{Mg}$ and increasing $\mathrm{Ca}$ and $\mathrm{Li}$ reflect the typical diffusion-formed profile of interstitial water, but in interval 19F-3, 0-15 cm, and Section 27F-2, there is an obvious increase in $\mathrm{Fe}, \mathrm{Si}$, and $\mathrm{Mn}$ and a slight 
Figure F46. Surface-enhanced Raman spectra of sediment extracts: asphaltene (residual oil), a core sample rich in SOM, a blank, and a sample containing both SOM and residual petroleum.
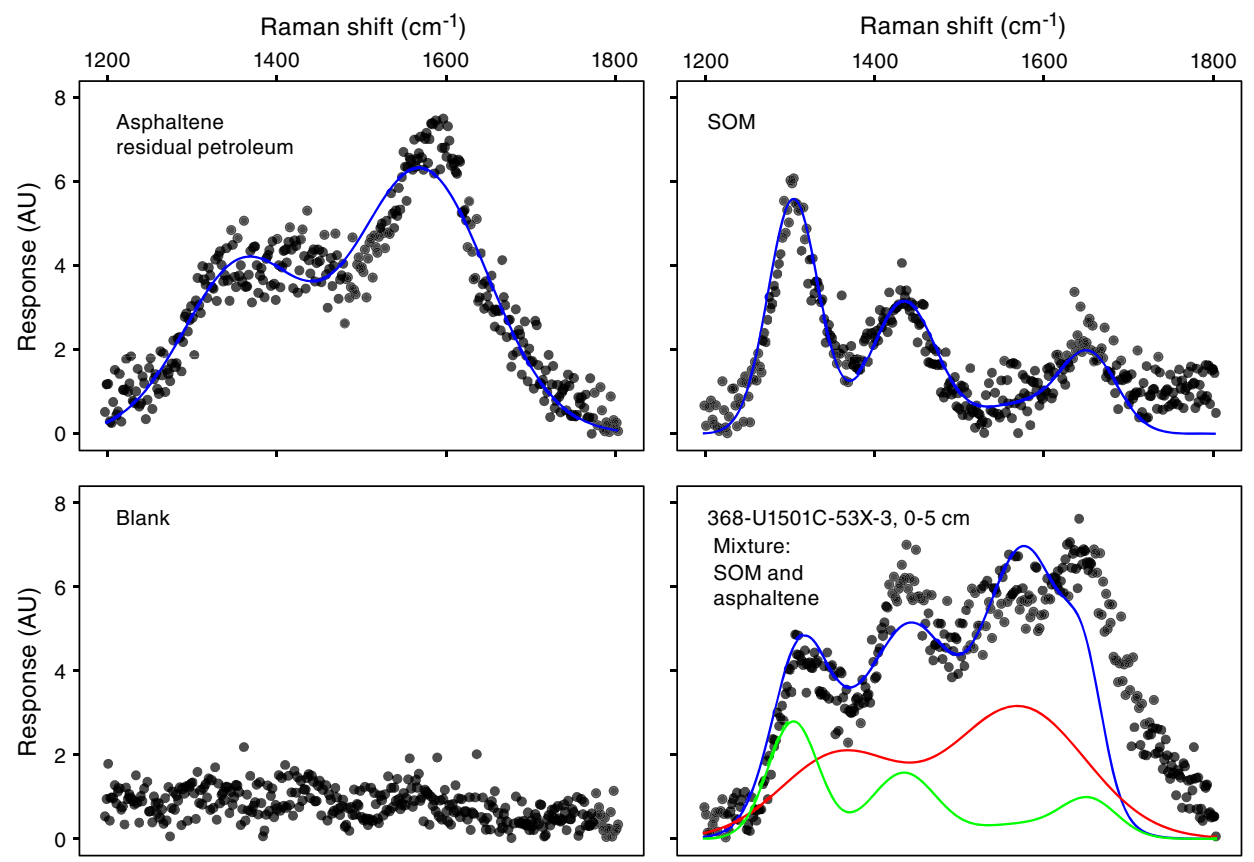

Table T15. Interstitial water analyses, Hole U1501C and U1501D. View table in PDF format. Download table in CSV format.

decrease in $\mathrm{Na}, \mathrm{Cl}$, and $\mathrm{Br}$. This atypical profile is similar to that of the deep fluids in Hole U1502A, which are suggested to derive from basalt. In interstitial water Zone 3 (interval $44 \mathrm{X}-4,0-15 \mathrm{~cm}$, through 50X-4, 0-15 cm) sulfate, chloride, and bromide concentrations are anomalously low. One possible origin for this fluid migration is along sand and silt layers in which a fluid depleted in $\mathrm{Cl}, \mathrm{Br}$, and Na migrates. Alternatively, the chemical composition may be explained by a sand body or sand-rich unit being isolated by differential compaction within a hydraulically sealed mudstone; in such a case, the water would represent relict formation water. In interstitial water Zone 4 (interval 53X-4, 0-15 cm, through 61X-2, 0-15 cm), all major anion and cation concentrations are normal for that depth and the region (Li et al., 2015a).

Alkalinity varies within Hole $\mathrm{U} 1501 \mathrm{C}$, ranging from 1.5 to 8.8 $\mathrm{mM}$ (shown in Figure F47). In interstitial water Zone 1, alkalinity increases to a peak concentration of $7.1 \mathrm{mM}$ at $16.72 \mathrm{~m}$ (Sample 2H$5,0-5 \mathrm{~cm}$ ). This change in alkalinity is most likely caused by degradation of organic matter. In interstitial water Zone 2, alkalinity decreases to $\sim 3.5 \mathrm{mM}$ at $59 \mathrm{~m}$ and remains constant at $\sim 3.5 \mathrm{mM}$ to $100 \mathrm{~m}$. Alkalinity increases again to a peak concentration of $8.8 \mathrm{mM}$ at $230 \mathrm{~m}$ and then decreases downhole to the base of interstitial water Zone 2. The changes of alkalinity in interstitial water Zone 2 are similar to those of carbonate, suggesting that alkalinity might be influenced by the dissolution of carbonate. The $\mathrm{pH}$ value decreases slowly from the seafloor to the bottom of interstitial water Zone 2 and then increases to a maximum $(\mathrm{pH}=7.94)$ at the bottom of interstitial water Zone 4 (Sample 61X-2, 0-15 cm).

In interstitial water Zones 1 and 2, interstitial water chlorinity values are mostly $\sim 560 \mathrm{mM}$, similar to the standard seawater value (559 mM; Figure F47). In interstitial water Zone 3, chlorinity values decrease to the minimum ( $498 \mathrm{mM})$ at $356 \mathrm{~m}$. About 10\% decreased chlorinity implies that a "freshwater" component might be present. The bromide depth profile is similar to the variation observed for chlorinity but with a maximum that occurs at a different depth. Bromide concentration also decreases to a minimum in interstitial water Zone 3. It is worth noting that slightly decreased chlorinity and bromide concentrations were observed in Cores 19X-3 and 21X-3.

The dissolved sulfate profile decreases from $27.2 \mathrm{mM}$ at the seafloor to $3.7 \mathrm{mM}$ at the bottom of Hole U1501C (Figure F47). In interstitial water Zone 1, sulfate concentrations decrease sharply, most likely caused by bacterially mediated organic matter diagenesis in upper sediments. Downhole, this decline is more gradual and can best be explained by diffusion processes. The interstitial water contains significant amounts of sulfate $(3.7 \mathrm{mM})$ to the bottom of the hole, indicating that sulfate is not completely consumed in Hole U1501C. A similar case was observed at IODP Site U1431 (Li et al., 2015b), but otherwise this lack of sulfate reduction is unusual. Dissolved $\mathrm{NH}_{4}{ }^{+}$concentrations increase from $336 \mu \mathrm{M}$ at 7.5 $\mathrm{m}$ to a maximum of $492 \mu \mathrm{M}$ at $16 \mathrm{~m}$ in interstitial water Zone 1 . Interstitial water Zones 2-4 have slight variations in $\mathrm{NH}_{4}{ }^{+}$concentrations. A maximum in dissolved phosphate concentrations is 30.6 $\mu \mathrm{M}$ at $3 \mathrm{~m}$ in interstitial water Zone 1 . In interstitial water Zones 24 , phosphate concentrations are generally low, just about several micromolars.

The $\mathrm{Na}^{+}$profile is similar to $\mathrm{Cl}^{-}$and $\mathrm{Br}^{-}$(Figure F47). Sodium concentrations are mostly constant $(\sim 480 \mathrm{mM})$ in interstitial water Zones 1 and 4, decrease to a minimum (399 mM) in interstitial water Zone 3, and increase to standard seawater value $(\sim 480 \mathrm{mM})$ in interstitial water Zone 4 (likely representing contamination). Sodium concentrations in interstitial water Zone 3 are about $20 \%$ of that in other units. The $\mathrm{K}^{+}$and $\mathrm{Mg}^{2+}$ profiles decrease in a similar way to each other from the surface to the bottom of the hole. Decreases in potassium and magnesium are possibly due to diagenetic reactions occurring in sediment, such as clay ion exchange. Contrary to the potassium and magnesium pore water profiles, the $\mathrm{Ca}^{2+}$ 
Figure F47. Interstitial water alkalinity, $\mathrm{pH}$, chloride, bromide, sulfate, phosphate, ammonium, sodium, potassium, calcium, and magnesium concentration profiles.

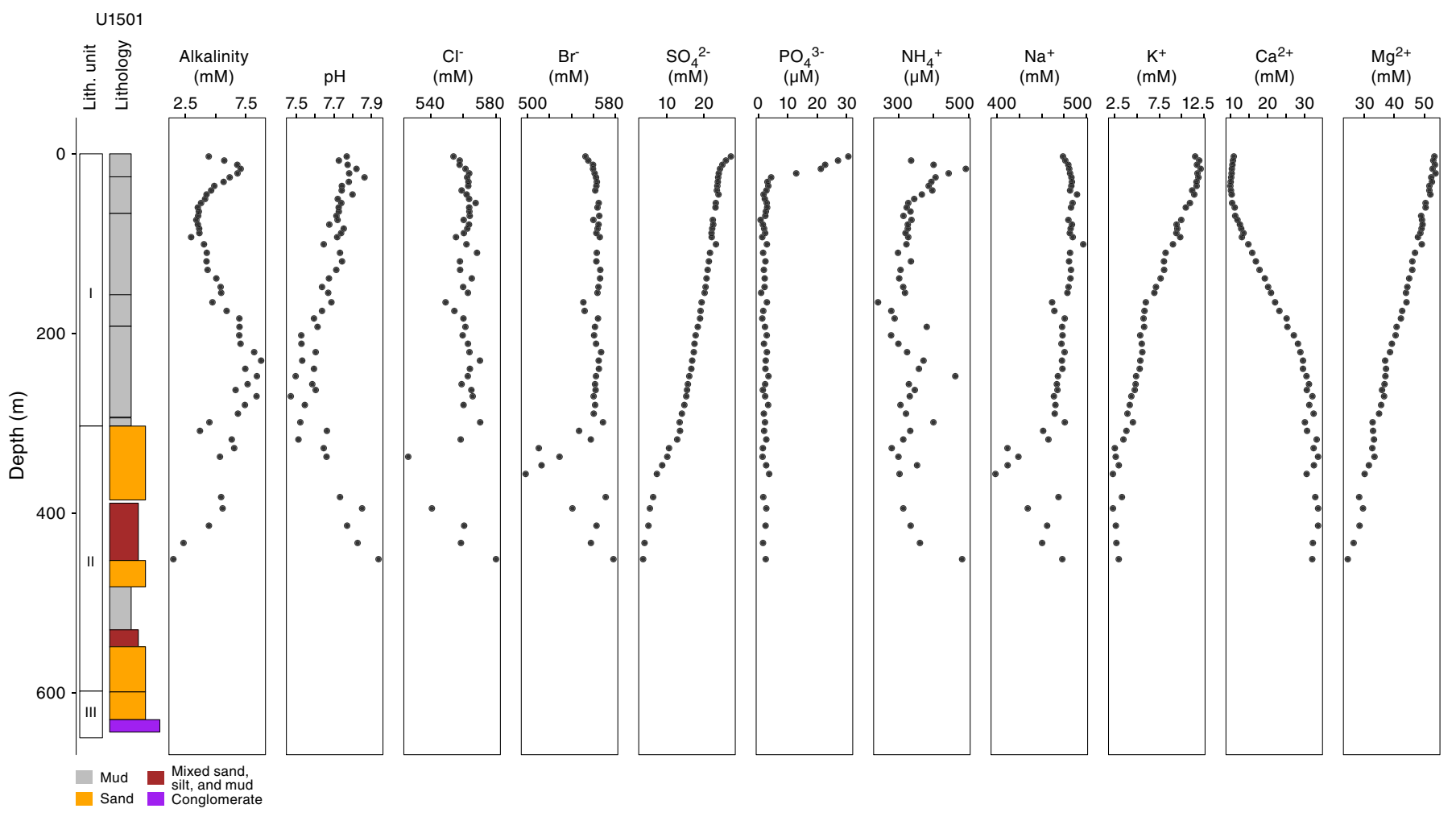

profile increases from the surface to a maximum concentration (33.7 $\mathrm{mM})$ at $337 \mathrm{~m}$, and below this depth calcium has a near-constant concentration. Changes in calcium concentration are mostly caused by carbonate diagenesis (i.e., dissolution and recrystallization of biogenic carbonate). The strontium profile in interstitial water is controlled by the dissolution of biogenic carbonate, so it is similar to the profile of calcium. Strontium concentrations increase from the subsurface to the maximum $(440 \mu \mathrm{M})$ at $269 \mathrm{~m}$ and remain around $400 \mu \mathrm{M}$ until the bottom of the hole (Table T16).

Dissolved $\mathrm{Ba}$ concentrations in the interstitial water are controlled by the formation and stability of the mineral barite $\left(\mathrm{BaSO}_{4}\right)$. Barium and sulfate concentrations are negatively correlated. In interstitial water Zone 1 , the dissolved Ba concentration is very low $(0.05 \mu \mathrm{M})$ and corresponds with the maximum in sulfate. In interstitial water Zones 2-4, Ba concentrations increase linearly to a maximum $(2.49 \mu \mathrm{M})$ at the bottom of Hole U1501C at the same time sulfate concentrations decrease to a minimum.

In interstitial water Zone 1, degradation of organic matter releases B into the interstitial water (Li and Jiang, 2010), so the dissolved B concentrations increase with depth (Figure F48). In interstitial water Zone 2, the B profile is likely driven by clay mineral cation exchange (e.g., adsorption onto and desorption from clay minerals). Decreased B concentrations are observed in interstitial water Zones 2 and 3. Lithium is also easily adsorbed onto clay minerals such as kaolinite and smectite and/or other terrigenous sediments. Thereafter, in interstitial water Zone 1, the concentration of $\mathrm{Li}$ is lower than modern seawater $(25 \mu \mathrm{M})$. In interstitial water Zone 2 , Li concentrations increase gradually from $27 \mu \mathrm{M}$ to a maximum $(499 \mu \mathrm{M})$ and then decrease to lower concentrations in interstitial water Zones 3 and 4 . The increases in Li concentration are possibly due to the diagenetic release of Li from clay minerals and/or diffusion from Li-enriched deep fluids.

Silica concentrations in interstitial water Zone 1 are controlled by the dissolution of siliceous microfossils that release silica into interstitial water. In interstitial water Zone 2, peaks in $\mathrm{Si}, \mathrm{Fe}$, and $\mathrm{Mn}$ concentrations were observed between Sample 368-U1501C-21F-3, $0-10 \mathrm{~cm}$, and Section 27F-2 at the same time as decreased $\mathrm{Na}, \mathrm{Cl}$, and $\mathrm{Br}$ concentrations. The changes in geochemical parameters are similar in character to those of the deeper fluids in Hole U1502A. The profiles of dissolved Fe and Mn change in a way similar to that of $\mathrm{Si}$, perhaps because Fe and $\mathrm{Mn}$ are affected by the degradation of organic matter, which also occurs in surface sediments. At Site U1502, there was enrichment in Mg and Ca, but in Hole U1501C changes in $\mathrm{Ca}$ and $\mathrm{Mg}$ do not appear to be off-trend.

In summary, the most obvious changes in interstitial water chemical composition occur in Sections 368-U1501C-19F-3 through $27 \mathrm{~F}-2$ and deeper than $300 \mathrm{~m}$. Fluid from these sections have similar geochemical parameters to the deep fluid from Hole U1502A, which is suggested to be influenced by the dissolution of mafic minerals within basalt. The fluid below $300 \mathrm{~m}$ corresponds to a boundary between lithostratigraphic Units I and Unit II. A sharp change in interstitial water chemistry at very shallow subseafloor depths suggests very rapid degradation of organic matter within the uppermost $16 \mathrm{~m}$.

\section{Bulk sediment and rock geochemistry}

We analyzed a total of 64 sediment samples from Holes U1501B, U1501C, and U1501D for major and minor element concentrations by inductively coupled plasma-atomic emission spectroscopy (ICPAES) (Table T17). 
Figure F48. ICP-AES iron, manganese, silica, strontium, boron, and lithium concentration profiles.

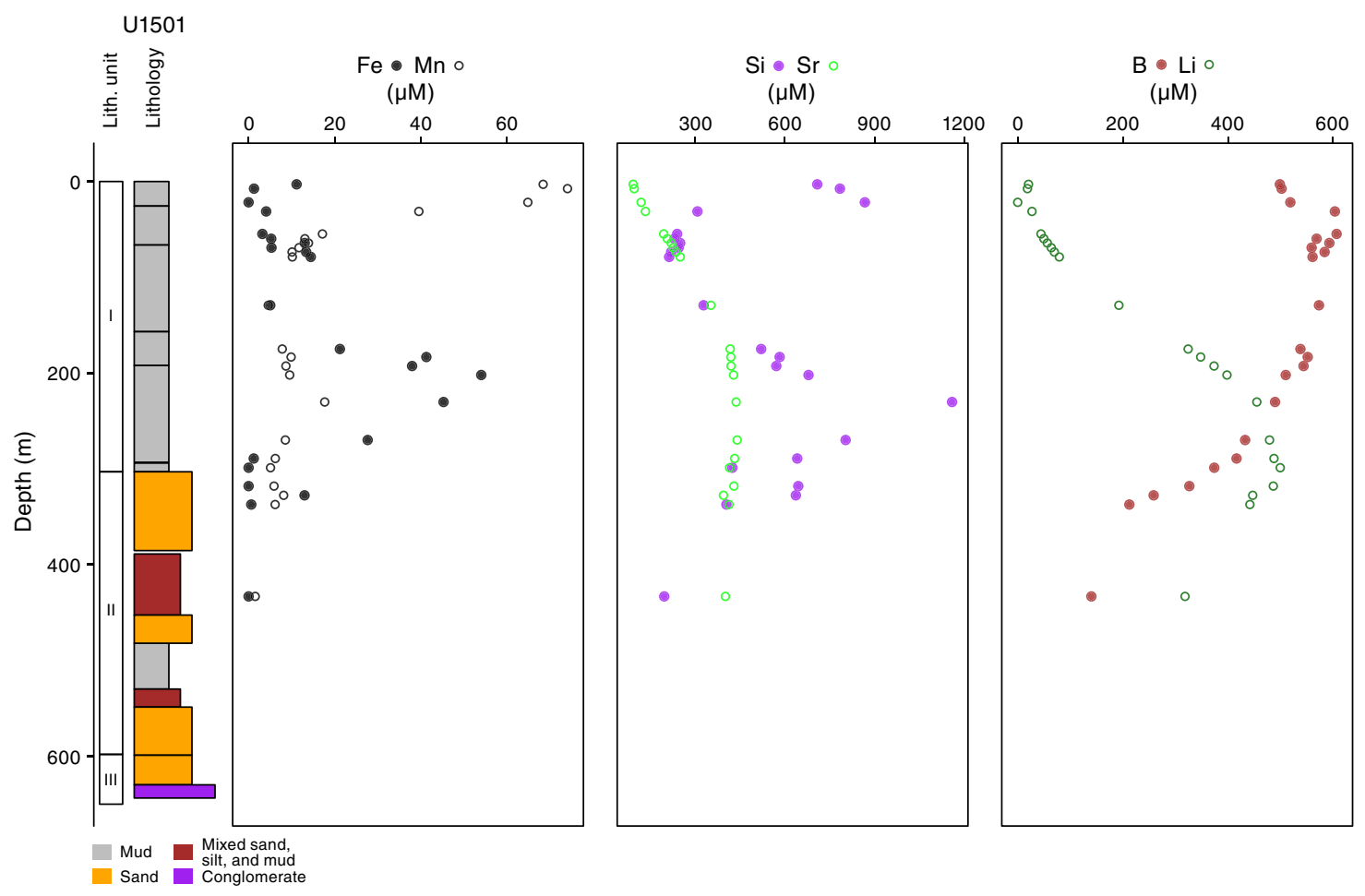

Table T16. Interstitial water minor elements, Hole U1501C. View table in PDF format. Download table in CSV format.

Table T17. Major element oxide and minor element contents of sedimentary samples, Site U1501. View table in PDF format. Download table in CSV format.

Elemental compositions primarily reflect geological units and changes in lithology. Silica, aluminum, and calcium oxides are the major elements and typically account for greater than $90 \mathrm{wt} \%$ of the elemental composition of most lithologies (Figure F49). In lithostratigraphic Unit I, calcium oxide contents are high, and within the foraminifer-rich interval they exceed $40 \mathrm{wt} \%$ (consistent with the unit being a high-carbonate ooze, e.g., $>50 \%$ carbonate). Within lithostratigraphic Units II and III, calcium (as carbonate) is less common and the units are predominantly siliciclastic with sharp distinctions between units that are mud-rich and the feldspathic, sandier lithologies toward the base of the hole. In lithostratigraphic Unit III, a steady decrease in potassium content reflects the upward transition from an orthoclase-rich to less orthoclase-rich sandstone. Sandstones at the top of lithostratigraphic Unit II are far muddier than those beneath, and the relatively increased potassium content is associated with increased aluminum content. Likely, these changes reflect an upward increase in clay content in lithostratigraphic Unit II. Such a progression is consistent with increased compositional maturity within the sediment, brought on by the transition from first- to second-cycle sediments (Suttner et al., 1981) (e.g., the breakdown and conversion of orthoclase to clay minerals during weathering in the sediment source). Within the basal part of lithostratigraphic Unit II, sodium and potassium are both high, which is also consistent with the presence of first-cycle feldspathic sediments.
Parameters previously proposed to represent sedimentological processes for the SCS were also evaluated (Clift et al., 2014). In detail, Figure F50 shows the depth profile of a parameter based on the major cations in smectite $(\mathrm{Mg}$ and $\mathrm{Na})$ and illite $(\mathrm{K})$. The variation of $(\mathrm{Mg}+\mathrm{Na}) / \mathrm{K}$ values reflects the different clay assemblages in the lithostratigraphic units. The $\mathrm{Ti} / \mathrm{Ca}$ parameter has previously been used as a proxy of clastic flux (Clift et al., 2014), with Ti being dominated by the presence of heavy detrital minerals (e.g., rutile and titanite) and Ca by biogenic carbonate. The high peak in Ti/Ca depth profile (lithostratigraphic Subunit IA) is most possibly correlated with intensified clastic delivery from continents; furthermore, the high $\mathrm{Ti} / \mathrm{Ca}$ with low $\mathrm{Al} / \mathrm{Si}$ (low ratios of clay and quartz sand) values in Subunit IA (Figure F49) may indicate a high-energy transport regime during this period.

\section{Discussion of organic, formation water, and inorganic chemical results}

The following synthesis is based on the geochemical data presented in the preceding sections. Based on the lack of methane generation and sulfate reduction and the fixation of sulfur as pyrite within sediments, aspects of early diagenetic environments at Site $\mathrm{U} 1501$ are atypical in comparison to other sites in the region ( $\mathrm{Li}$ et al., 2015a). Deepwater marine mudstones do not regularly have high TOC values, largely because their depositional environments in general do not favor high rates of organic carbon preservation (Demaison and Moore, 1980). However, the low TOC values (<0.5 wt\%) found in lithostratigraphic Subunit IIA are also at odds with nearby sites such as Site U1499. The low methane content of sediments and sulfate reduction profiles also differ markedly between the two sites; there is no evidence of a present-day sulfate-methane transition zone (SMTZ) at Site U1501 (Barnes and Goldberg, 1976). Figure F51 summarizes these features. Within lithostratigraphic Unit II, 
Figure F49. (A) Major element oxide abundances and lithostratigraphic unit-normalized (B) $\mathrm{CaO} / \mathrm{SiO}_{2},(\mathrm{C}) \mathrm{K}_{2} \mathrm{O} / \mathrm{SiO}_{2}$, and (D) $\mathrm{Al}_{2} \mathrm{O}_{3} / \mathrm{SiO}_{2}$. $\mathrm{B}-\mathrm{D}$ : solid black circles = Subunit IA, open circles = Subunits IB-IF, red circles = Unit II, green circles $=$ Unit III.

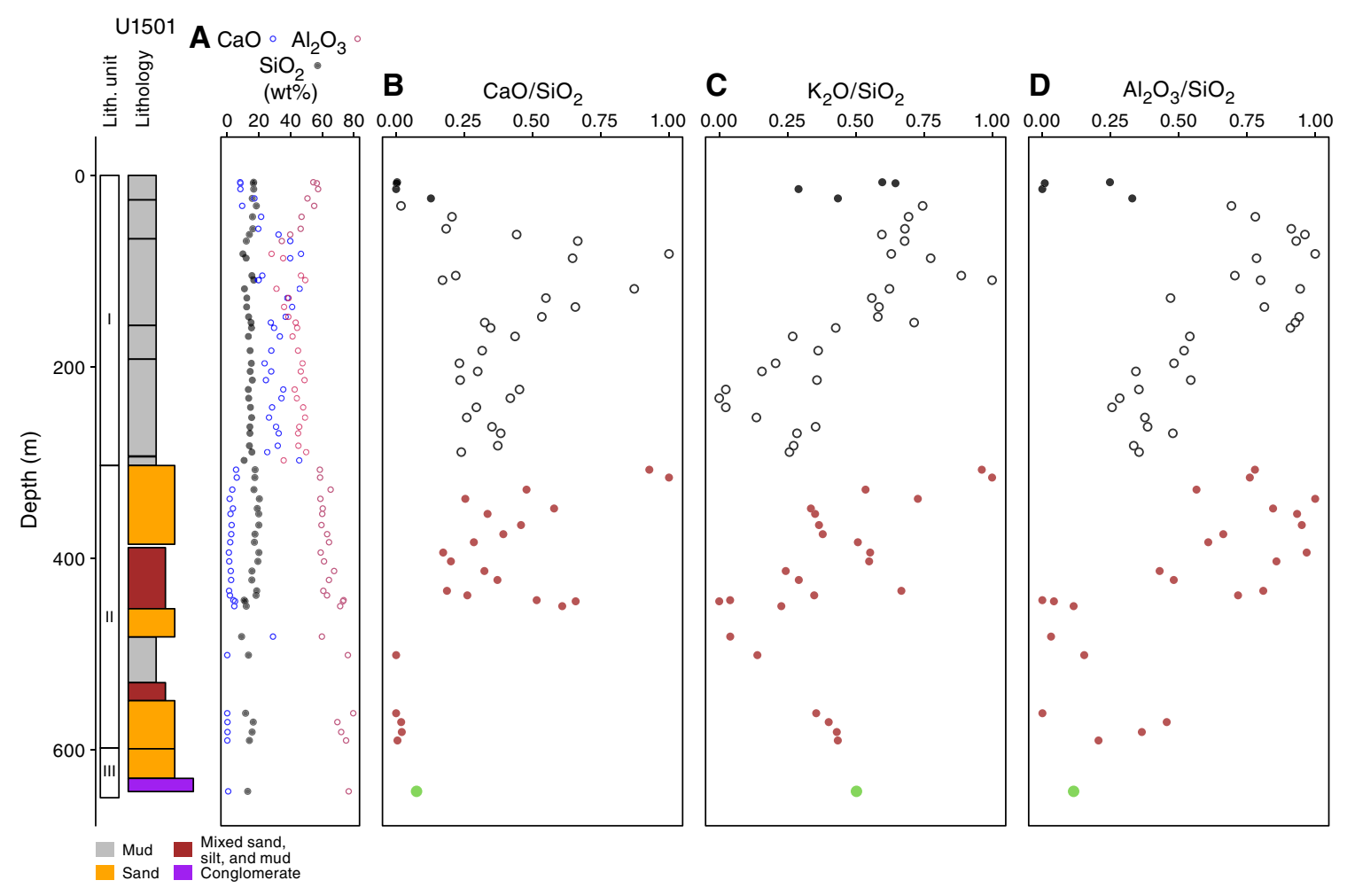

sulfate reduction is inhibited relative to Site U1499. Perhaps unsurprisingly, because sulfate is ultimately converted to pyrite, the main form in which pyrite is stabilized within sediments, the TS content of Unit I is mostly low, except for the topmost interval, where both iron and organic carbon contents are high.

Causes for inhibited pyrite formation and sulfate reduction might include a lack of iron, low organic matter content (organic matter serves as a reductant), and a dysoxic environment (Berner and Raiswell, 1984). Both factors are present at Site U1501, as can be seen in Figure F51. Iron, which is particularly noticeable in this regard, has an inverse correlation to barite. Barite and thereby $\mathrm{Ba}$ can also serve as indicators for past redox boundaries in sediments (Torres et al., 1996). Barite precipitates and is fixed in sediment where sulfate is stable under oxic conditions, generally found above the SMTZ where sulfate is most abundant. The inversely varied $\mathrm{Ba}$ and Fe thus likely denote varying diagenetic conditions within the sediment column. Overall, this strongly indicates that Site U1501, situated at a basement high, has seen a substantial change in early diagenesis conditions during recent geological history. 
Figure F50. Geochemical parameters correlated with sedimentological processes. A. (Mg + Na)/K ratio as proxy for smectite and illite. B. Ti/Ca ratio normalized by lithostratigraphic unit. Solid black circles = Subunit IA, open circles = Subunits IB-IF, red circles = Unit II, green circles = Unit III.

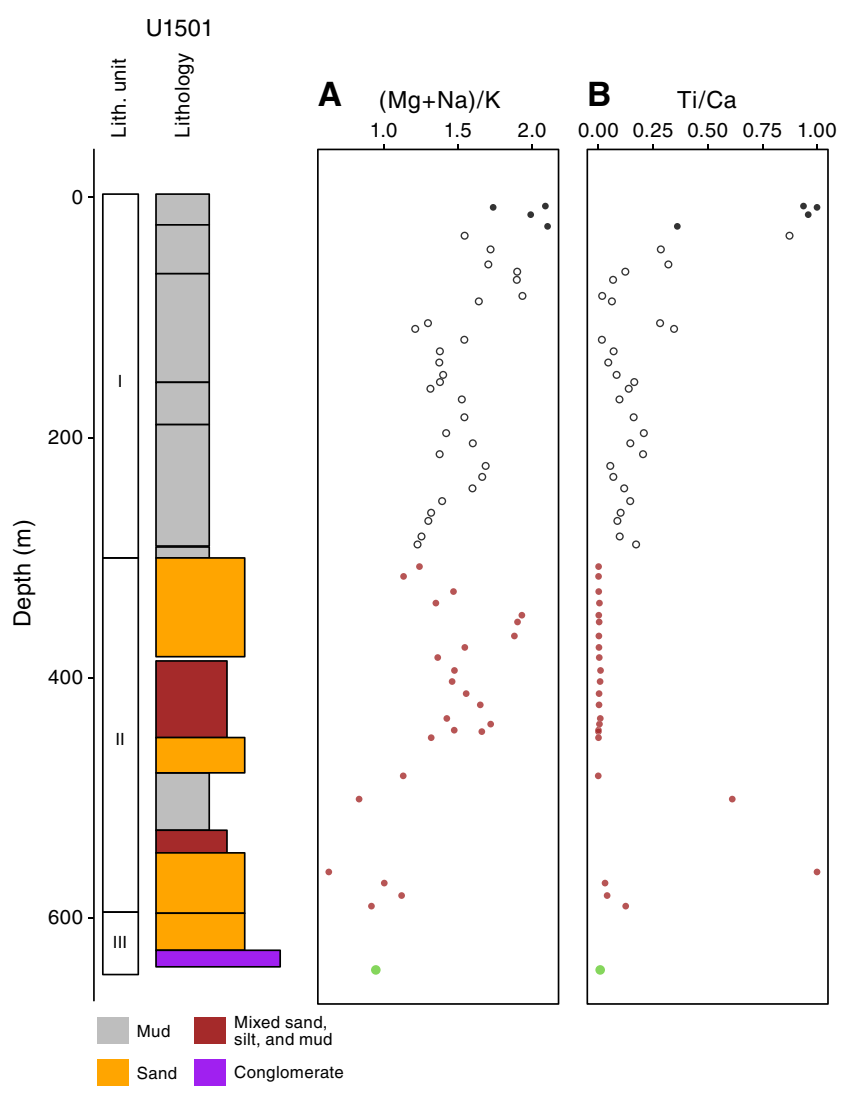

Figure F51. Variations in diagenetic history, Site U1501. A. Interstitial water Zones 1-4 and redox state of early stage diagenesis (green $=$ reducing, red $=$ dysoxic). B. Rescaled (from 0 to 1 ) interstitial water sulfate concentrations. $\mathrm{AU}=$ arbitrary units. C. Elemental and oxide abundances (Fe as Fe $\mathrm{O}_{3}$ ). D. TOC and TS.

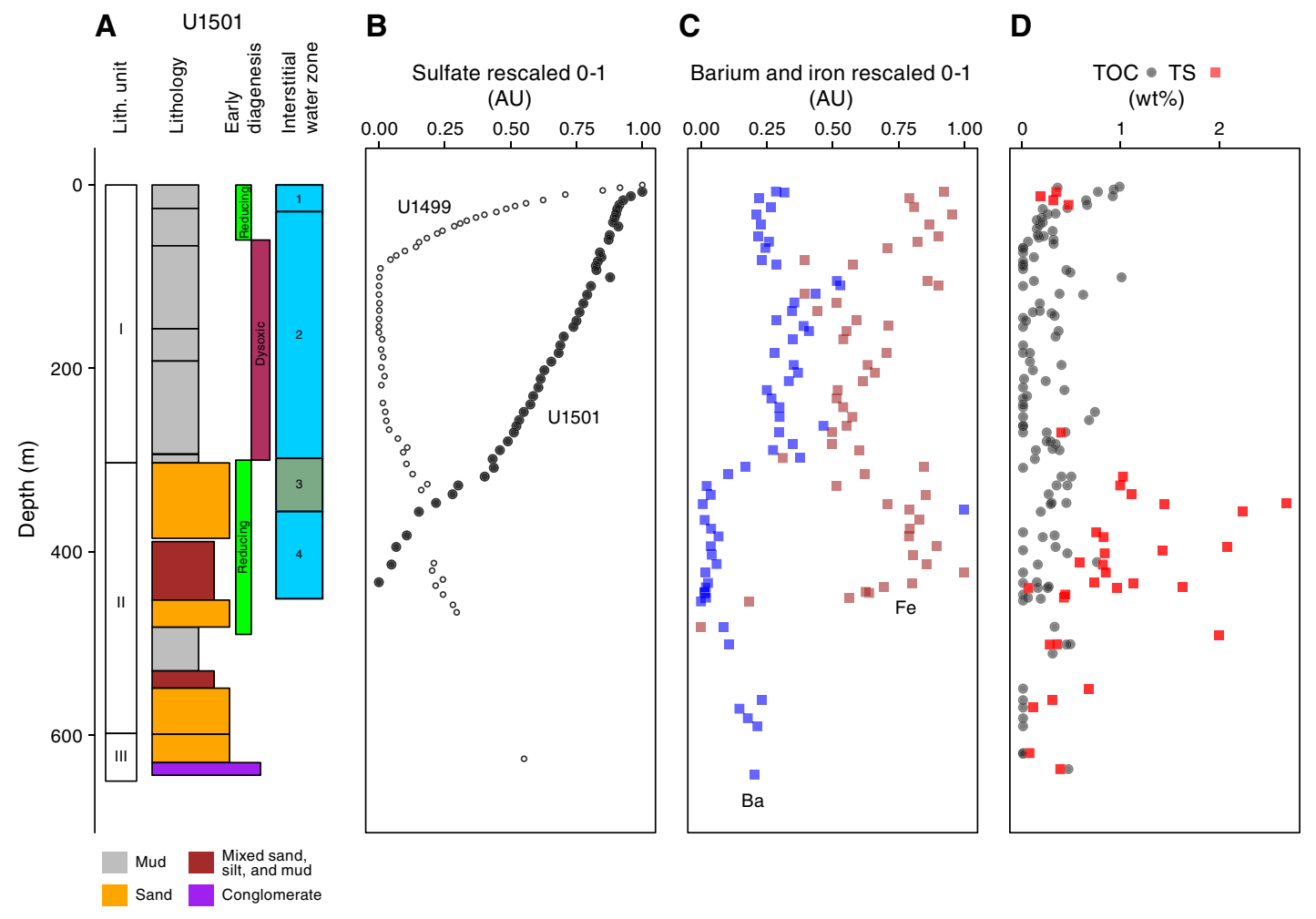




\section{Physical properties}

Sediment and rock physical properties were measured on cores from Holes U1501A (0-9.5 m), U1501B (0-9.5 m), U1501C (0$461.9 \mathrm{~m})$, and U1501D (433.5-644.3 m). After cores reached thermal equilibrium with ambient temperature at $\sim 20^{\circ} \mathrm{C}$, gamma ray attenuation (GRA) density, magnetic susceptibility, and $P$-wave velocity were measured every $2 \mathrm{~cm}$ using the Whole-Round Multisensor Logger (WRMSL). After WRMSL scanning, NGR was measured on the whole-round sections with a counting period of $10 \mathrm{~min}$ and a measurement spacing of $10 \mathrm{~cm}$. Thermal conductivity was measured next with a needle probe inserted into whole-round cores on unconsolidated sediments and with a puck probe on split section halves on hard rocks. Following core splitting, color reflectance and magnetic susceptibility measurements were taken from the archive halves using the point magnetic susceptibility (MSP) sensor on the Section Half Multisensor Logger (SHMSL). Discrete MAD measurements were obtained on every other section of the working halves. $P$-wave velocity was also measured on the working halves with the $P$-wave caliper (PWC) and $P$-wave bayonet (PWB) pulserreceiver systems of the Section Half Measurement Gantry (SHMG).

The following major physical property units were distinguished at Site U1501:

- PP Unit 1 (0-300 m),

- PP Unit 2 (300-450 m),

- PP Unit 3 (450-600 m), and

- PP Unit 4 (600-657 m).
These units are described below. The results from the WRMSL, SHMSL, SHMG, and discrete sample measurements are shown in Figure F52.

\section{Natural gamma radiation}

The NGR intensity measured at an energy level characteristic for $\mathrm{K}, \mathrm{U}$, or Th is proportional to the content of that element in the sediment. These elemental proportions can help improve stratigraphic correlation and may be indicative of the geochemistry and mineralogy of the sediments (e.g., De Vleeschouwer et al., 2017). In general, the NGR count of sandstones increases with silt and shale content and a higher percentage of minerals other than quartz (Russell, 1944).

NGR values in PP Unit 1 are represented by two major intervals (Figure F53). The upper interval from the seafloor to $\sim 65 \mathrm{~m}$ ranges from $\sim 20$ to $\sim 50$ counts/s and is associated with NGR values that peak around the middle of this depth range. The lower interval of PP Unit 1 has a similar but broader trend and ends at an abrupt increase in NGR values to $\sim 60$ counts/s at $\sim 300 \mathrm{~m}$. In PP Unit $2, \mathrm{NGR}$ values vary rapidly, showing an overall increase followed by a decrease in values with depth to the top of PP Unit 3 at $\sim 450 \mathrm{~m}$. PP Unit 3 has a steady rise in NGR values and a sharp increase at $\sim 600$ $\mathrm{m}$ to $\sim 80$ counts/s that characterizes PP Unit 4 .

Concentrations of $\mathrm{K}, \mathrm{U}$, and Th were estimated using the NGR counts and bulk density measurements for Hole U1501C according to the methods by De Vleeschouwer et al. (2017). The trends in the NGR counts are not as clearly expressed in the Th concentrations as

Figure F52. Physical properties, Holes U1501A and U1501B. cps = counts per second.

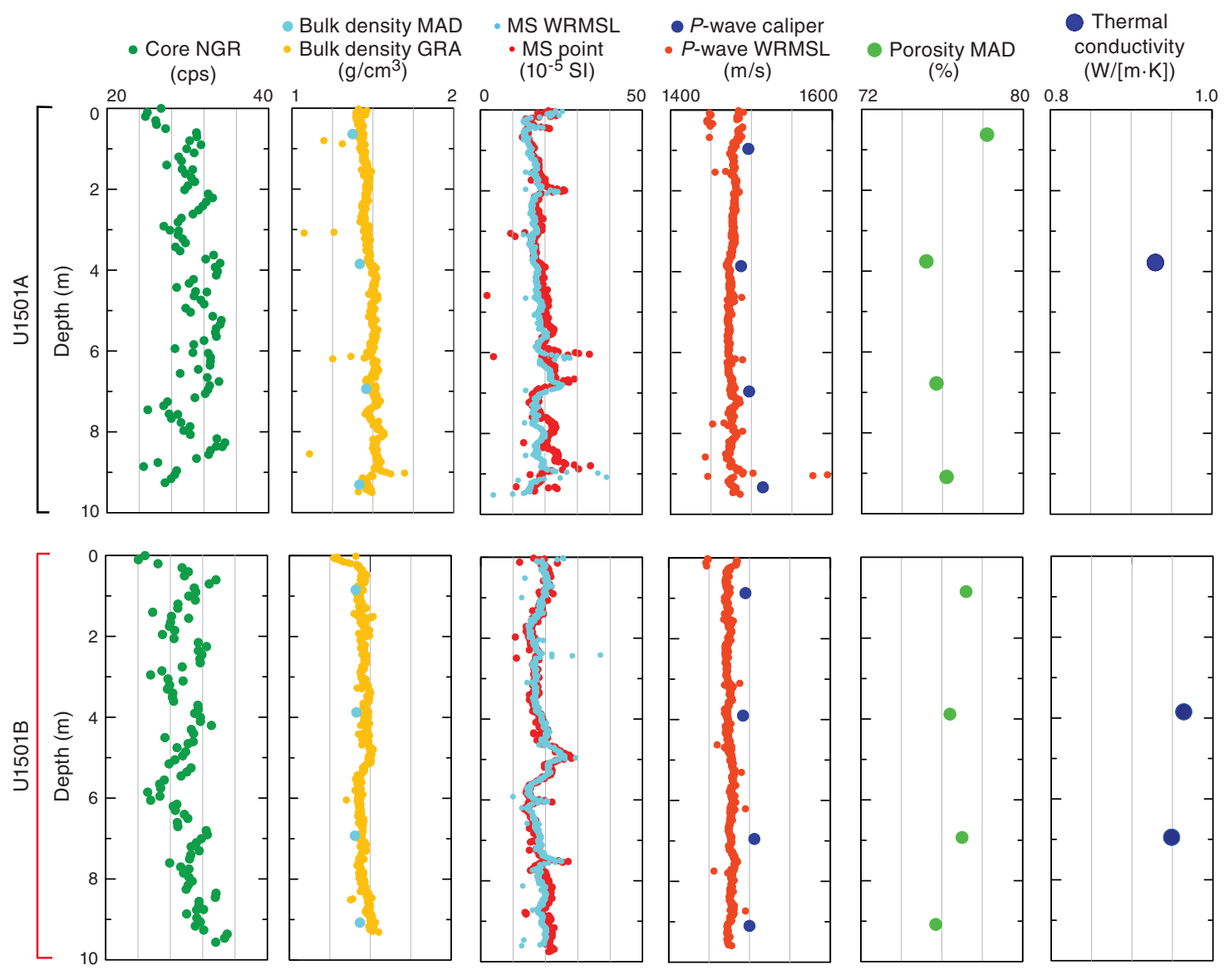


Figure F53. Physical properties, Holes U1501C and U1501D. Note logarithmic scales used for magnetic susceptibility and $P$-wave velocity.

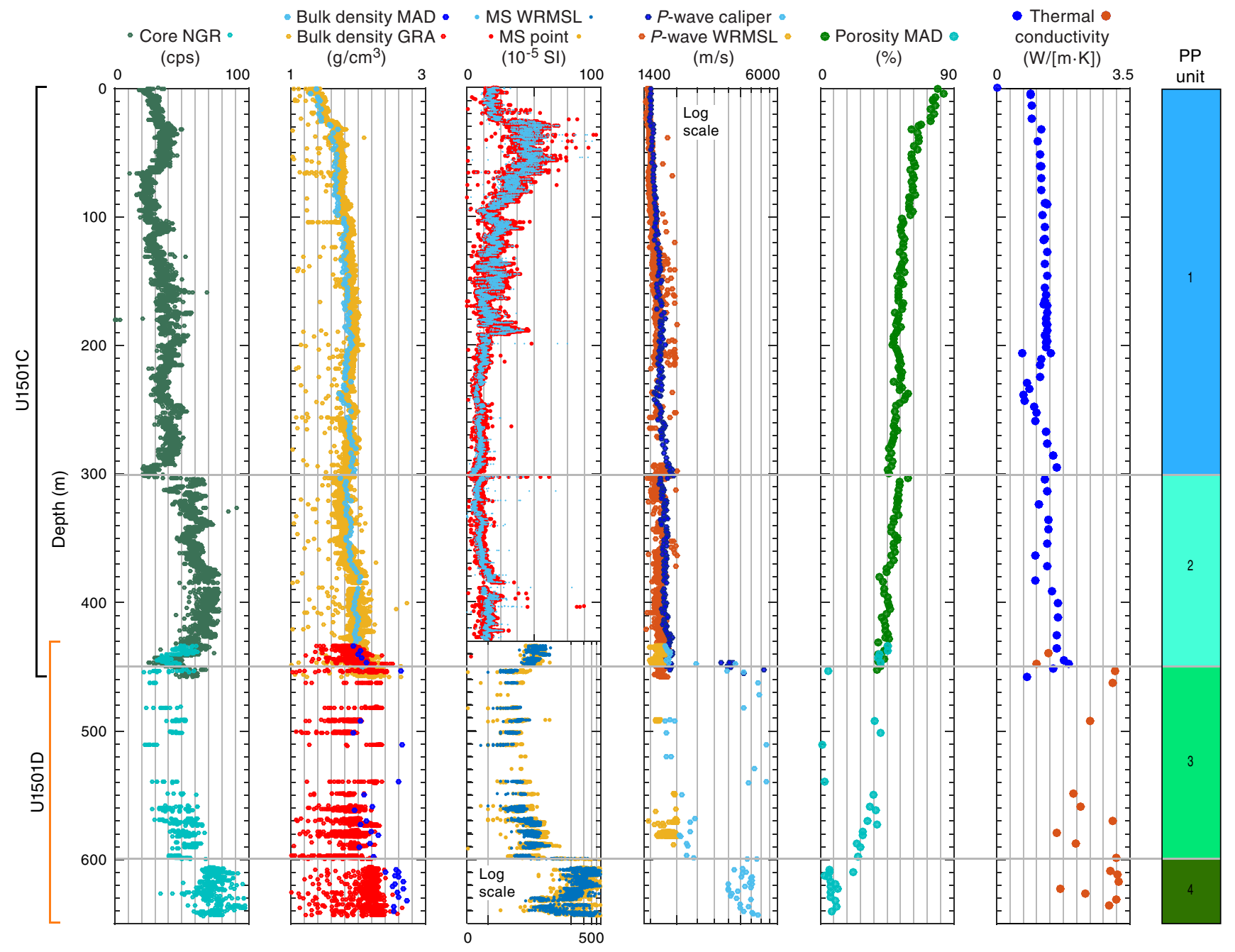

they are in the K percent weight and U concentrations, which show very similar variations to the total NGR count values (Figure F54).

\section{$P$-wave velocity}

In PP Unit $1, P$-wave velocities gradually increase with depth from $\sim 1450$ to $1931 \mathrm{~m} / \mathrm{s}$, reflecting sediment compaction (Figure F53). $P$-wave velocities decrease sharply at the boundary between PP Units 1 and 2 to $1650 \mathrm{~m} / \mathrm{s}$. In PP Unit 2 (300-450 m), velocities increase again with depth but remain lower than $2000 \mathrm{~m} / \mathrm{s}$ downhole to $\sim 450 \mathrm{~m}$, where they spike to values of $\sim 3500 \mathrm{~m} / \mathrm{s}$ and higher. Scattered high velocity measurements continue to the bottom of PP Unit 3 (450-600 m), but they become the norm in PP Unit 4 (600$657 \mathrm{~m}$ ), where they generally exceed $\sim 3500 \mathrm{~m} / \mathrm{s}$.

\section{Thermal conductivity}

In PP Unit 1 , thermal conductivity increases gradually with depth from $\sim 0.88 \mathrm{~W} /(\mathrm{m} \cdot \mathrm{K})$ near the seafloor to $\sim 1.64 \mathrm{~W} /(\mathrm{m} \cdot \mathrm{K})$ at $\sim 300 \mathrm{~m}$ (Figure F53). The increasing trend is interrupted at $\sim 265 \mathrm{~m}$ by a slight reduction in thermal conductivity caused by poor connection between the core and the probe. Reliable measurements resumed below $267 \mathrm{~m}$. A drop in thermal conductivity from 1.576 to $1.255 \mathrm{~W} /(\mathrm{m} \cdot \mathrm{K})$ occurs at the boundary between PP Units 1 and 2 $(\sim 300 \mathrm{~m})$, followed by increasing trends in PP Unit 2 . Thermal con- ductivity is more variable in the lowermost section of PP Unit 2 and in PP Units 3 and 4 (440-622 $\mathrm{m})$, where it ranges from $\sim 1.350$ to $3.600 \mathrm{~W} /(\mathrm{m} \cdot \mathrm{K})$.

\section{Density and porosity}

In PP Unit 1, GRA and MAD bulk densities increase gradually from $\sim 1.3 \mathrm{~g} / \mathrm{cm}^{3}$ just below the seafloor to $\sim 1.9 \mathrm{~g} / \mathrm{cm}^{3}$ (Figure F55) at $\sim 300 \mathrm{~m}$. Dry density increases with depth from $\sim 0.6$ to $\sim 1.5$ $\mathrm{g} / \mathrm{cm}^{3}$, and porosity decreases with depth from $80 \%$ to $45 \%$, consistent with increasing compaction. At the boundary with PP Unit 2 ( $\sim 300 \mathrm{~m})$, bulk and dry densities abruptly decrease, whereas porosity increases up to $60 \%$. Grain density remains constant at $2.7 \mathrm{~g} / \mathrm{cm}^{3}$.

In PP Unit 2, bulk and dry densities slightly increase with depth from 1.7 to $2.0 \mathrm{~g} / \mathrm{cm}^{3}$ and from 1.1 to $1.7 \mathrm{~g} / \mathrm{cm}^{3}$, respectively. Scattered grain density values range from 2.6 to $2.9 \mathrm{~g} / \mathrm{cm}^{3}$. Porosity decreases with depth from $60 \%$ to $40 \%$. The boundary between PP Units 2 and $3(450 \mathrm{~m})$ is marked by an abrupt increase in bulk (2.0 to $\left.2.7 \mathrm{~g} / \mathrm{cm}^{3}\right)$ and dry $\left(1.7\right.$ to $\left.2.7 \mathrm{~g} / \mathrm{cm}^{3}\right)$ densities. In PP Unit 3, densities vary, with an overall increasing trend toward the bottom of the unit. At $\sim 600 \mathrm{~m}$, corresponding to the transition between PP Units 3 and 4, bulk and dry densities increase rapidly from $\sim 2.2$ to $>2.6$ $\mathrm{g} / \mathrm{cm}^{3}$ and from 2.0 to $2.5 \mathrm{~g} / \mathrm{cm}^{3}$, respectively. In contrast, porosity at this depth decreases sharply from $20 \%$ to $5 \%$. 
Figure F54. NGR measurements, Hole U1501C. K, U, and Th concentrations are derived from NGR and GRA density measurements using method of De Vleeschouwer et al. (2017).

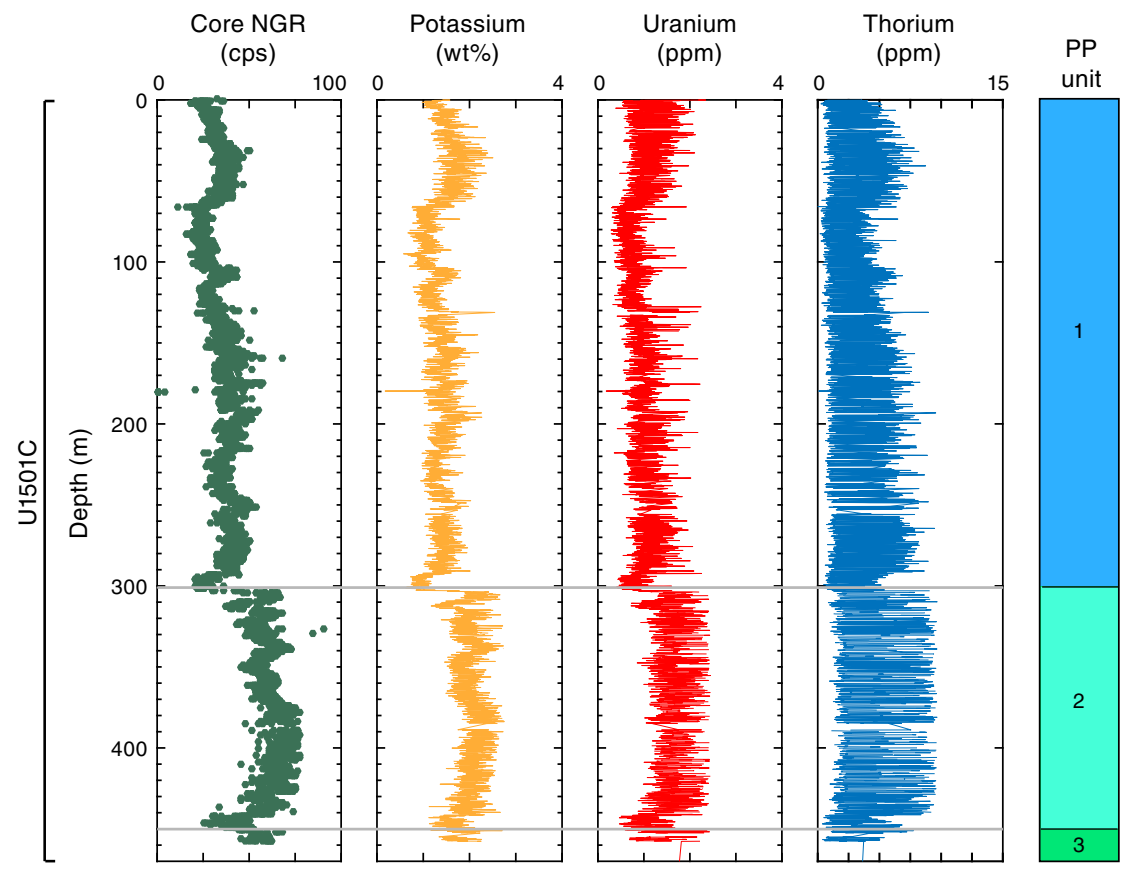

Figure F55. GRA bulk density and MAD bulk density, dry density, grain density, and porosity, Holes U1501C and U1501D.

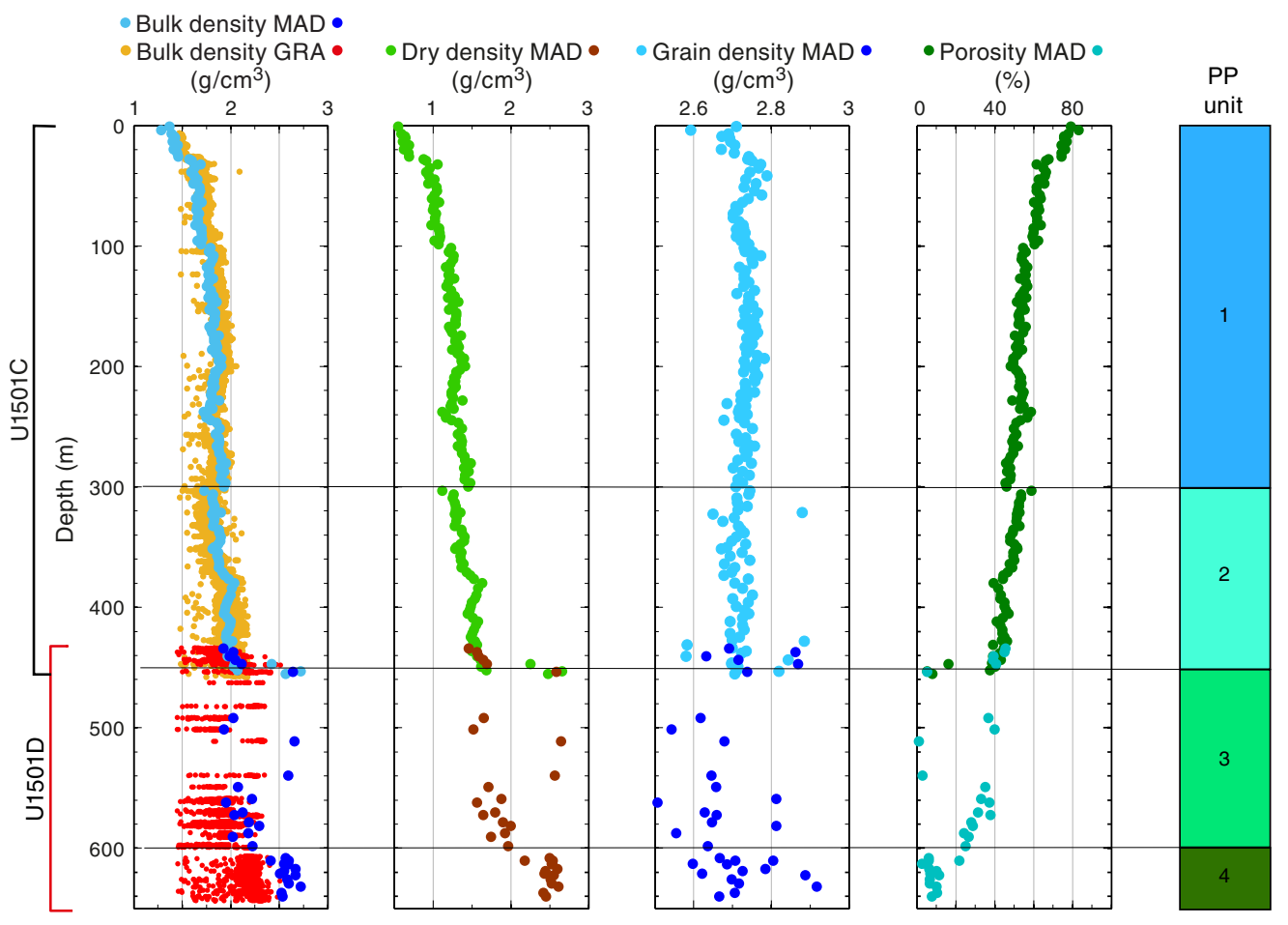

PP Unit 4 has an average bulk density of $2.6 \mathrm{~g} / \mathrm{cm}^{3}$ and dry density of $2.5 \mathrm{~g} / \mathrm{cm}^{3}$ (Figure F55). Grain densities and porosities in this unit fluctuate between 2.5 and $2.9 \mathrm{~g} / \mathrm{cm}^{3}$ and $3 \%$ and $10 \%$, respectively.

\section{Color reflectance spectrophotometry}

$L^{*}$ values are higher in PP Unit 1, reflecting the higher concentration of biogenic carbonate in the uppermost $300 \mathrm{~m}$. Reflectance parameters $\mathrm{a}^{*}$ and $\mathrm{b} *$ increase sharply from the seafloor to $\sim 120 \mathrm{~m}$ to their highest values and then drop in similar fashion before $\sim 180$ $\mathrm{m}$. Values remain low thereafter to the boundary with PP Unit 2. L* drops sharply at the boundary at $\sim 300 \mathrm{~m}$, marking the transition between PP Units 1 and 2 and reflecting the increase in clay in the formation (Figure F56). L*, a*, and $b^{*}$ values in PP Unit 2 show relatively constant trends with a variable range. The transition between PP Units 2 and 3 is characterized by a slight increase of $L^{*}$ 
Figure F56. Sediment color reflectance parameters $\mathrm{L}^{*}, \mathrm{a}^{*}$, and $\mathrm{b}^{*}$ and $\mathrm{CaCO}_{3}$ content, Holes U1501C and U1501D.

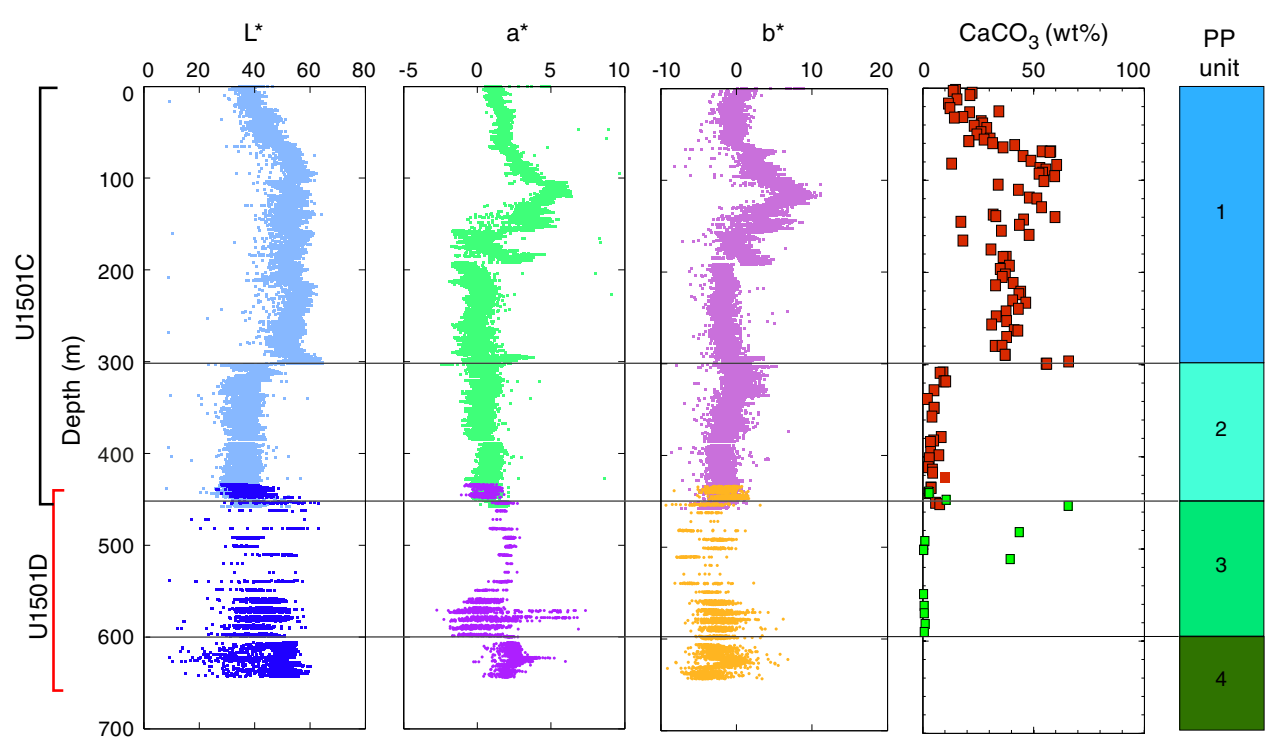

and $\mathrm{b}^{*}$. An abrupt increase in $\mathrm{a}^{*}$ occurs at $600 \mathrm{~m}$, coinciding with the change from glauconite sand to sandstone (see Lithostratigraphy). Below this depth, all reflectance values remain relatively constant.

\section{Magnetic susceptibility}

Magnetic susceptibility rapidly increases from the seafloor to $\sim 50 \mathrm{~m}$ and then gradually decreases downhole throughout the lower section of PP Unit 1 until abruptly increasing at the boundary between PP Units 1 and 2, coinciding with the change from nannofossil ooze to nannofossil-rich clay (see Lithostratigraphy). Magnetic susceptibility remains constant in PP Unit 2, with a slight decrease at the boundary between PP Units 2 and $3(450 \mathrm{~m})$ from 15 $\times 10^{-5}$ SI to $5 \times 10^{-5}$ SI that is followed by an abrupt increase at the transition between PP Units 3 and 4. Magnetic susceptibility values in PP Unit 4 are relatively high, locally exceeding $500 \times 10^{-5}$ SI (Figure F53).

\section{Red, green, blue}

Red, green, blue (RGB) values show similar trends to the $L^{*}$ values throughout Holes U1501A-U1501D (Figures F56, F57). From the seafloor through the upper portion of PP Unit 1 ( 95 m), RGB values increase from 100 to 160 , whereas they remain constant and vary between $\sim 140$ and 160 in the lower portion of PP Unit 1. A marked decrease in RGB from 170 to 100 was observed at the boundary between PP Units 1 and 2 (Figure F57). RGB values in PP Unit 2 remain relatively constant at $\sim 100$, followed by another increase from 70 to 150 in PP Unit 4.

\section{Discussion and summary}

Sediments recovered from Site U1501 are generally composed of both biogenic (calcareous or siliceous ooze) and terrigenous material dominated by either quartz or clay. Changes in sediment physical properties not only reflect relative amounts of these components but also their compaction/lithification state and may also be related to depositional environments. Overall, we found a strong correlation between the sediment physical properties and the designated lithostratigraphic units (Figure F53; see Lithostratigraphy). The GRA and bulk densities increase with depth, reflecting the in-
Figure F57. RGB values, Holes U1501C and U1501D.

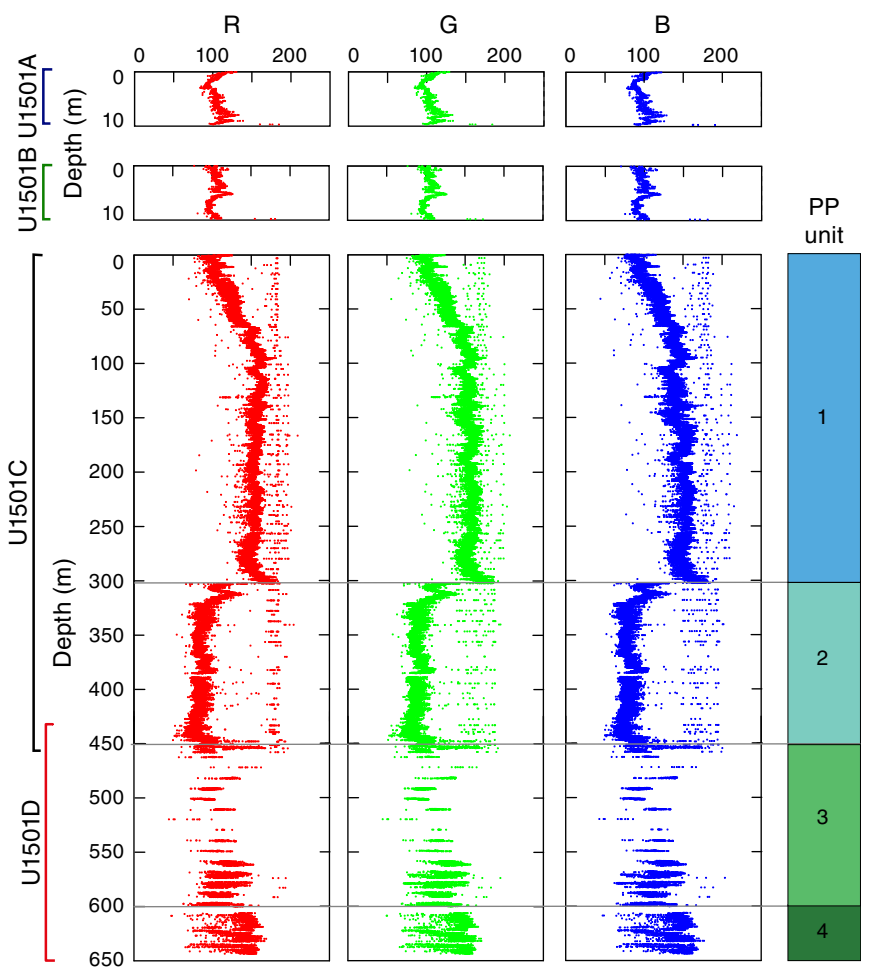

creasing compaction of sediments with depth. Porosity values are consistent with this trend and have an inverse relationship with density (Figure F55). The lowest porosities (about 5\%) were encountered in sandstones from the lowermost section of Holes $\mathrm{U} 1501 \mathrm{C}$ and U1501D and are related to diagenetic processes (i.e., lithification and cementation).

Similarly, a general increase in $P$-wave velocity at Site U1501 from $1451 \mathrm{~m} / \mathrm{s}$ at the seafloor to $1931 \mathrm{~m} / \mathrm{s}$ at $302 \mathrm{~m}$ (Figure F53) reflects sediment compaction. This increase is followed by a sharp decrease in velocity at $302.9 \mathrm{~m}$ to $1796 \mathrm{~m} / \mathrm{s}$, marking a distinct lithologic transition from nannofossil ooze to a sand layer overlying clays 
(lithostratigraphic Units I to II; see Lithostratigraphy). Below this depth, $P$-wave velocities show a continuous trend of increasing values, with a second abrupt change from $1824 \mathrm{~m} / \mathrm{s}$ at $446.7 \mathrm{~m}$ to 2453 $\mathrm{m} / \mathrm{s}$ at $447.4 \mathrm{~m}$ that marks the change from an unconsolidated sand layer to a thin layer of sandstone (lithostratigraphic Subunits IIB to IIC). Rapid changes in velocities occur below this depth due to changes in lithology, with values ranging between 1760 and 5330 $\mathrm{m} / \mathrm{s}$. Below $\sim 600 \mathrm{~m}$, velocities lie in a narrower range and fluctuate between two sets of values, from as low as $\sim 3491 \mathrm{~m} / \mathrm{s}$ in a sand or silty sandstone layer to $4814 \mathrm{~m} / \mathrm{s}$ in a grayish sandstone.

Thermal conductivity values show a general increase from $\sim 0.88$ $\mathrm{W} /(\mathrm{m} \cdot \mathrm{K})$ near the seafloor to $\sim 3.60 \mathrm{~W} /(\mathrm{m} \cdot \mathrm{K})$ at $\sim 662 \mathrm{~m}$ (Figure F53). The gradual increase in value at shallow depths is likely due to sediment compaction. A significant decrease in thermal conductivity between 294 and $304 \mathrm{~m}$ is associated with a major change from lithostratigraphic Subunits IE-IF to IIA.

Changes in NGR values are associated with the major lithologic boundaries, but there are also significant, well defined fluctuations at a much finer scale (Figure F53). NGR values are low in lithostratigraphic subunits with high calcium carbonate content such as Subunit IC, and values are high in subunits with low carbonate content such as Subunits IIA and IIB. NGR values show some of the strongest fluctuations of all of the physical properties measurements and reflect rapid changes in lithostratigraphic subunits below $\sim 300 \mathrm{~m}$.

Comparison between $L^{*}$ values and lithologic content (Figure F56; see Lithostratigraphy) indicates that low $L^{*}$ values (darker intervals) are well correlated with clay-rich strata, whereas high $L^{*}$ values (lighter intervals) match well with carbonate-rich layers. There is also a close match between NGR and $L^{*}$; low $L^{*}$ values (dark intervals) correlate with high NGR values and vice-versa because they both reflect the amount of clay minerals.

In Hole U1501C, the highest magnetic susceptibility values are between 25 and $95 \mathrm{~m}$ (Figure F53), corresponding to lithostratigraphic Subunits IB and IC, which are dominated by calcite-rich minerals. We suspect that the weak trend representing changes in paramagnetic clay minerals, compared to diamagnetic calcite, is overprinted by the presence of ferromagnetic minerals. One of the prominent peaks in magnetic susceptibility correlates with the ash layer found in the uppermost section of Hole U1501A. In Hole U1501D, extremely high magnetic susceptibility values within lithostratigraphic Subunits IIIA and IIIB correspond to layers of sandstone or sandstone with gravels.

\section{Downhole measurements}

\section{Logging operations}

After recovering the last $\mathrm{RCB}$ core from $644.3 \mathrm{~m}$ in Hole U1501D, a wiper trip was made to condition the hole for logging operations and the RCB drill bit was released at the bottom of the hole. The bottom of the drill pipe was raised to logging depth at $2971.8 \mathrm{~m}$ drilling depth below rig floor (DRF [I give the scale whether it's used again or not because some people will know the acronym better]), or $115.1 \mathrm{~m}$ below the seafloor (Figure F58). Rig-up for downhole logging started at $0400 \mathrm{~h}$ (local time; UTC - 8 h) on 24 April 2017. The modified triple combo tool string started downhole at $0705 \mathrm{~h}$ on 24 April. The upward pass of the triple combo run began at 0815 $h$ and ended at $0905 \mathrm{~h}$. Because a section of collapsed hole was identified during the triple combo run, the logging operation ended after completion of the run. Logging tools were rigged down at 1200 h. Heave conditions were less than $\sim 0.2 \mathrm{~m}$ for the triple combo run; therefore, the active heave compensator was not used.
Figure F58. Logging operations summary, Hole U1501D.

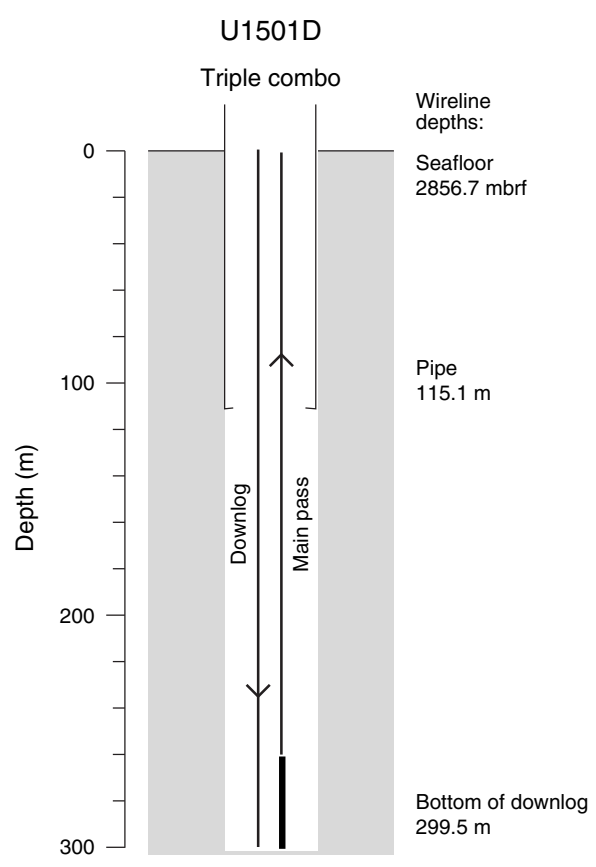

The modified triple combo tool string included the HNGS, HLDS, HRLA, and MSS (Figure F59). The centralized tools were run in the lower part of the tool string so it would be easier to lower the tool string past ledges than with an eccentralized tool (see Downhole measurements in the Expedition 367/368 methods chapter [Sun et al., 2018a]). The tool string encountered difficulty going down at approximately $173.3 \mathrm{~m}$ DSF and was unable to pass below $299.3 \mathrm{~m}$ DSF. The uphole log pass indicated a collapsed hole at $\sim 156.3 \mathrm{~m}$ DSF based on the caliper curve. For safety reasons, no further attempts to descend below that undergauge spot were made. Because the interval of the collapsed hole was located only $\sim 40 \mathrm{~m}$ below the bottom of the pipe, the originally planned FMS-sonic tool string was not run.

\section{Logging units}

The triple combo run in Hole U1501D allowed us to define four logging units that are correlated with lithostratigraphic units (see Lithostratigraphy), lithology, and physical properties (see Physical properties) (Figure F60).

\section{Logging Unit 1: base of drill pipe to $190 \mathrm{~m}$ WSF}

Logging Unit 1 is characterized by relatively high variability in the logs. For example, NGR values vary from $~ 38$ to 70 gAPI. Excursions to lower and higher values also punctuate the magnetic susceptibility log. This logging unit corresponds to lithostratigraphic Subunits IA-ID.

\section{Logging Unit 2: 190-260 m WSF}

Logging Unit 2 is characterized by relative homogeneity in the logs, without major excursions to higher or lower log values (e.g., magnetic susceptibility logs). It is also characterized by submeterscale layering, which is particularly evident in the caliper and resistivity logs. This logging unit corresponds to the lowest part of lithostratigraphic Subunit ID and the upper part of Subunit IE. 
Figure F59. Tools used in triple combo run, Site U1501. LEH-QT = logging equipment head-q tension, EDTC = Enhanced Digital Telemetry Cartridge.

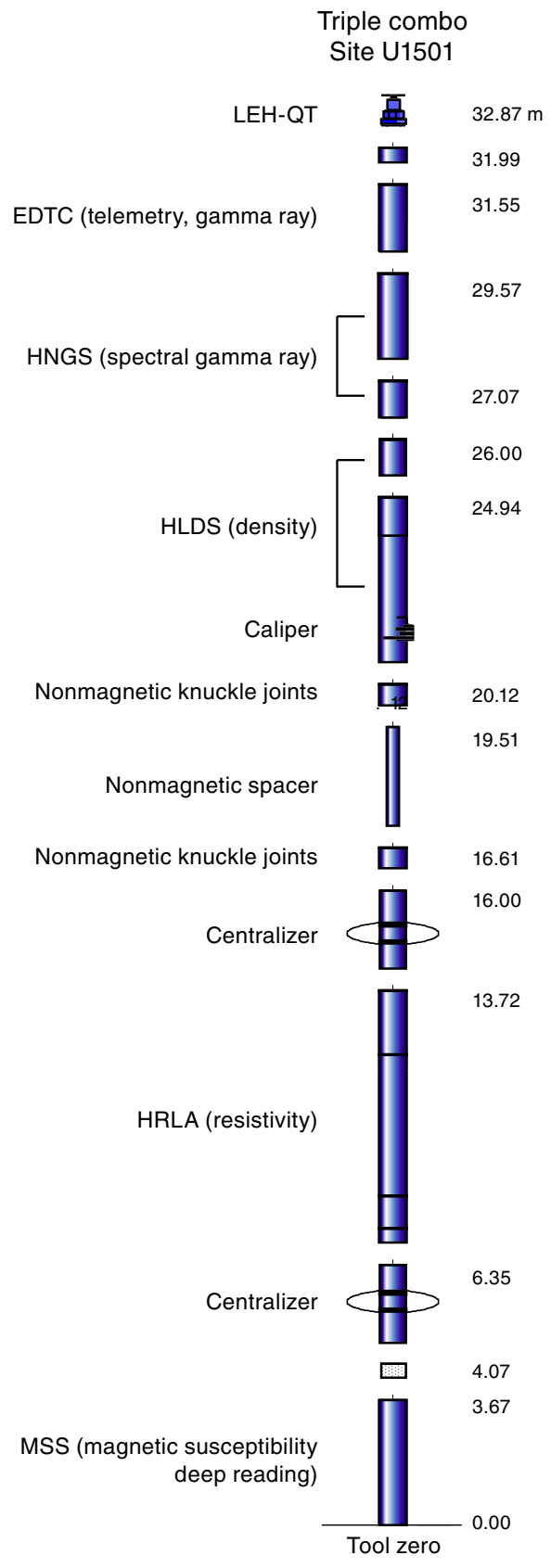

\section{Logging Unit 3: 260-275 m WSF}

Logging Unit 3 shows relatively high variability in the logs similar to that in logging Unit 1 . The NGR, density, and resistivity logs reveal higher amplitude variations than those in logging Unit 2. This logging unit corresponds to lithostratigraphic Subunit IE.

\section{Logging Unit 4: 275-300 m WSF}

The upper part of logging Unit 4 (275-285 m WSF) corresponds to a section in the lower part of lithostratigraphic Subunit IE. This logging unit does not exhibit any major excursions, similar to logging Unit 2. Although the bottom of the triple combo string reached $300 \mathrm{~m}$ WSF, the sensors did not reach the lower part of logging Unit 4 (285-300 m WSF), which corresponds to parts of lithostratigraphic Subunits IE and IF.

\section{Log data quality and lithology}

Log data quality was affected by the large borehole diameter, which exceeded the 17 inch limit of the HLDS caliper arm for about half of the logged interval (Figure F60). Some particularly large caving was inferred at 115-190 and 260-275 m WSF, leading to uncertainty in some of the log values in those intervals. A major thinbridged (narrow diameter) interval occurred at $\sim 156.3 \mathrm{~m}$ WSF.

The downhole logs reflect the lithology at Site U1501. The claydominated sediments have high NGR readings because of high concentrations of $\mathrm{K}$ and $\mathrm{Th}$ in clay minerals, whereas the calcareous sediments have lower NGR and magnetic susceptibility because of a relative lack of radioactive and magnetic minerals. The same NGR and magnetic susceptibility signatures are also seen in the physical property measurements made on cores from Hole U1501C, which enables the downhole logs from Hole U1501D to be correlated to the core data from Hole U1501C.

Contrasts in NGR and magnetic susceptibility can be seen in the logs as a whole. In particular, the calcareous beds can be readily identified in the downhole logs with low NGR. Sand-rich beds can be difficult to identify because they tend to be only partially recovered in the cores and because they become easily washed out in the borehole, resulting in anomalous log data values. In fact, the best indication of sand layers in the logs may be the diameter of the borehole. Such washouts also have very low NGR values.

\section{Downhole temperature and heat flow}

Four downhole temperature measurements were conducted in Hole U1501C using the advanced piston corer temperature tool (APCT-3). Temperatures range from $5.5^{\circ} \mathrm{C}$ at $47.3 \mathrm{~m} \mathrm{DSF}$ to $12.4^{\circ} \mathrm{C}$ at $132.8 \mathrm{~m}$ DSF, giving a geothermal gradient of $81.4^{\circ} \mathrm{C} / \mathrm{km}$ (Figure F61A). These measurements, together with the seafloor temperature of $1.2^{\circ} \mathrm{C}$, indicate that temperatures increase linearly with depth.

Thermal conductivity under in situ conditions was estimated from laboratory-determined thermal conductivity from Hole U1501C using the method in Hyndman et al. (1974) (see Physical properties in the Expedition 367/368 methods chapter [Sun et al., 2018a]). Thermal resistance (Figure F61C) was then calculated by integrating the inverse of the in situ thermal conductivity over depth (Figure F61B). A heat flow of $100.1 \mathrm{~mW} / \mathrm{m}^{2}$ was obtained from the linear fit between temperature and thermal resistance (Figure F61D) (Pribnow et al., 2000). The geothermal gradient and heat flow at Site U1501 are comparable to the relatively high values observed in some ODP, Integrated Ocean Drilling Program, and IODP sites in this part of the SCS, including Sites U1432 (100.1 $\left.\mathrm{mW} / \mathrm{m}^{2}\right)$ and $\mathrm{U} 1499\left(114 \mathrm{~mW} / \mathrm{m}^{2}\right)$. Together, these sites show that parts of the northern SCS margin have relatively high heat flow values (Li et al., 2010). 
Figure F60. Downhole logs, Hole U1501D. HSGR = total spectral gamma ray, HCGR = computed gamma ray (U-free). Downhole logs were taken in Hole U1501D, and lithology and core recovery data are from Hole U1501C.

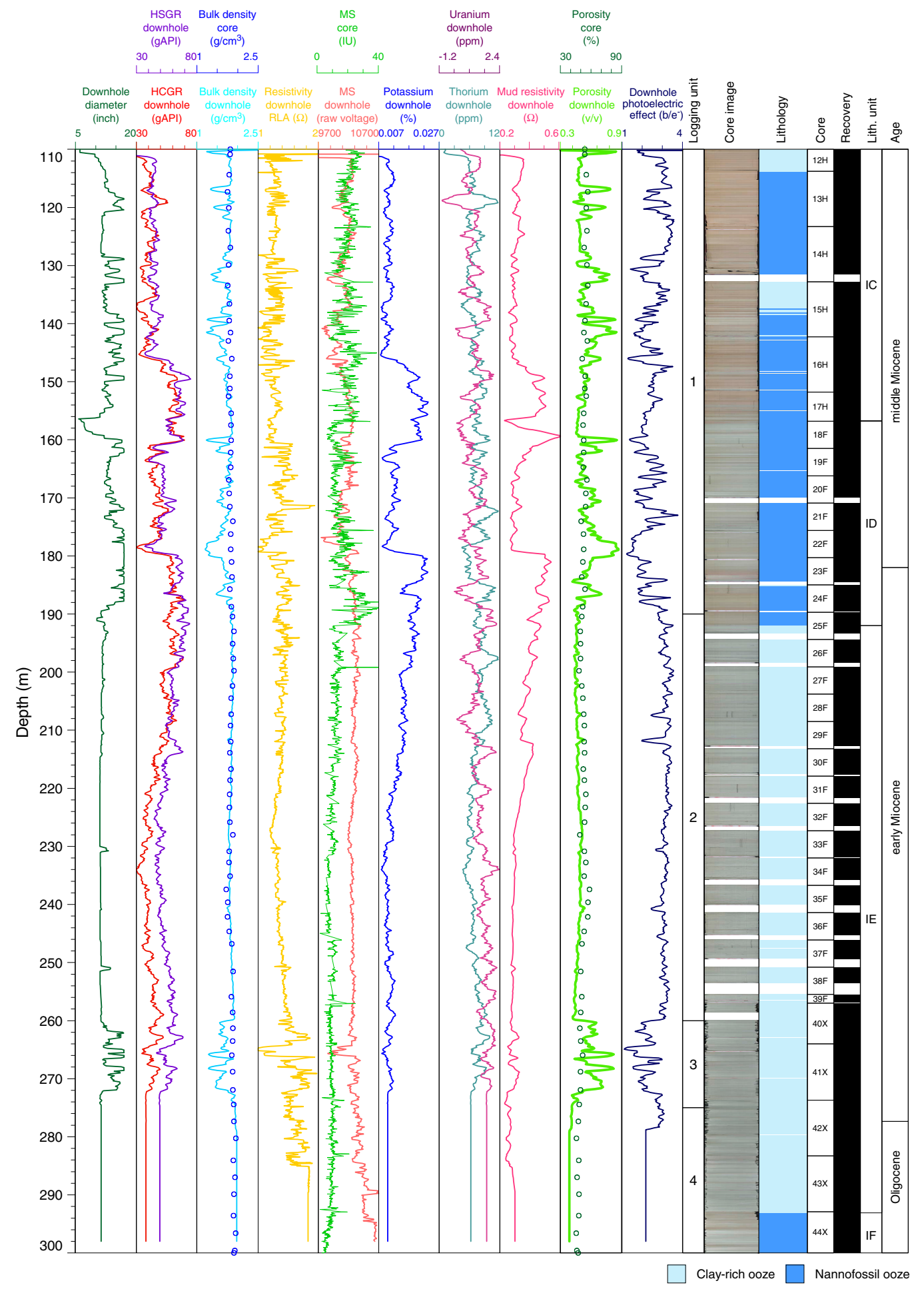


Figure F61. Heat flow calculations, Site U1501. A. Sediment temperatures. B. Thermal conductivity data, Hole U1501C. C. Calculated thermal resistance. D. Bullard plot of heat flow calculated from a linear fit of temperature data.
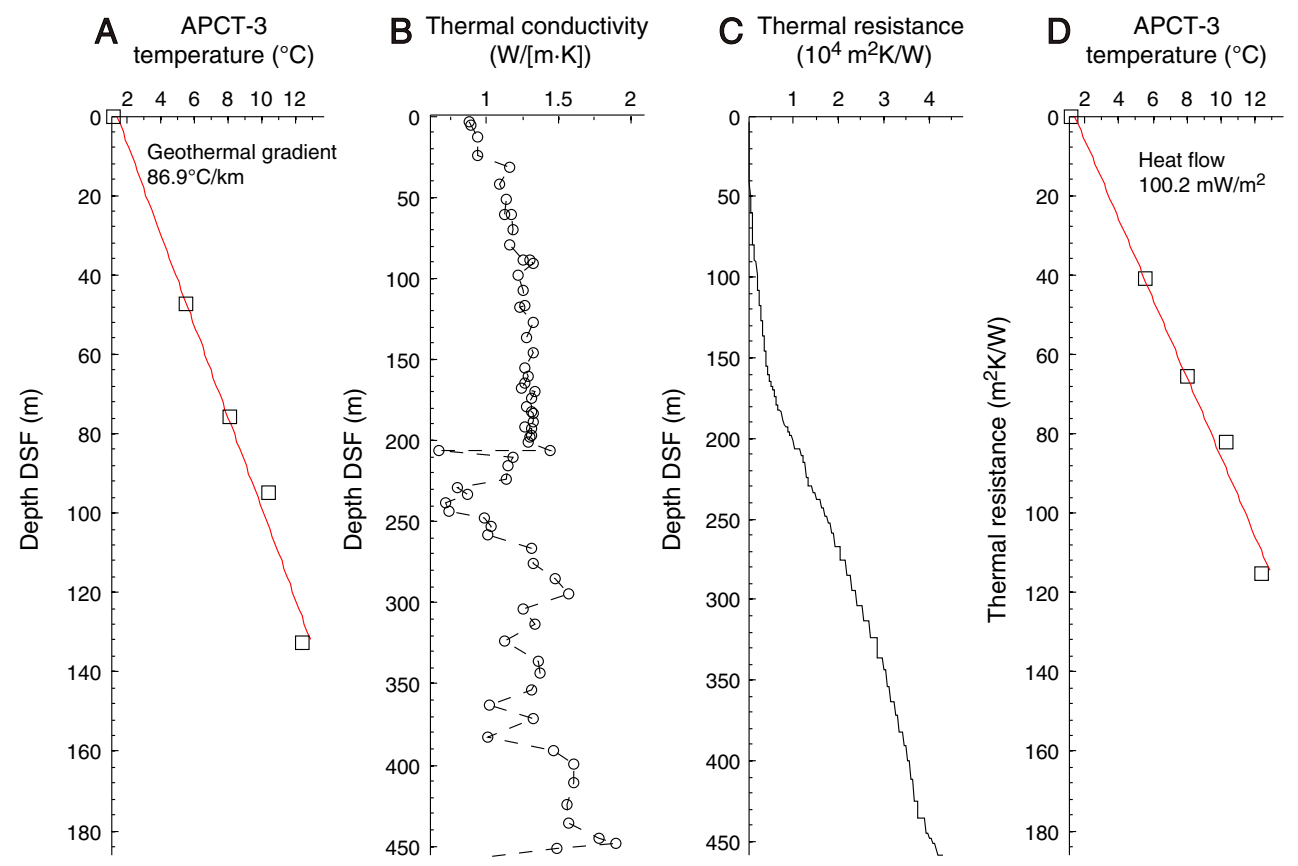

\section{Correlation to seismic data}

We conducted two sets of analyses to correlate core measurements to the time-based seismic data at Site U1501. First, we analyzed core data and made a direct comparison with the seismic reflection profile. Second, we constructed synthetic seismograms using the Site U1501 core data and compared the results with the traces in seismic profiles. Preliminary calculations were done during the expedition using a combination of Matlab scripts and Petrel software.

\section{Velocity and density data and comparison with seismic reflectors}

Whole-round core measurements, including $P$-wave velocity (PWL) and GRA density, were conducted from 0 to $457.7 \mathrm{~m}$ in Hole $\mathrm{U} 1501 \mathrm{C}$ and from 433.5 to $643.5 \mathrm{~m}$ in Hole U1501D (Figure F62). Pwave velocity was also measured along the $x$-axis with the PWC system on working-half sections. MAD measurements were performed on discrete samples, one every other section. In addition, HLDS density measurements were obtained from downhole logging in Hole U1501D from 115 to $300 \mathrm{~m}$ (see Physical properties and Downhole measurements). After outliers were cleaned, the wholeround PWL data are in good agreement with the PWC velocities of core samples. The HLDS density values from downhole logging are also in good agreement with MAD data for intervals away from borehole enlargements (Figure F60).

Seismic velocity and density show significant variations in quality with depth, affecting calculations of TWT and synthetic seismograms. From 0 to $\sim 450 \mathrm{~m}$, PWC velocity is of excellent quality. From $\sim 450$ to $\sim 608 \mathrm{~m}, \mathrm{PWC}$ velocity is highly scattered. From $\sim 608$ to $\sim 643.5 \mathrm{~m}$, the number of PWC measurements is very limited, whereas the PWL data provide some constraints. For the density data, both the whole-round and discrete sample measurements provide excellent constraints in the $0-450$ and 608-643.5 m intervals,

respectively. However, data recovery is poor at 450-608 m (Figure F62).

Site U1501 core measurements show distinct changes in physical properties and lithology in a number of depth intervals (see Physical properties). In general, these intervals correlate well with the depth intervals of strong amplitudes in the seismic reflection profile (Figure F62). Intervals with increasing velocity and density with depth often correlate with strong positive amplitudes in the seismic reflection profile, whereas decreases correspond to negative amplitudes. Such correlations are especially clear between the velocity and density profiles and the depth-converted seismic trace at Site U1501.

\section{Time-depth relationship}

The PWC velocity measurements from Holes U1501C and U1501D were used to calculate the time-depth relationship (TDR) model of seismic waves. We first calculated a preliminary model of TDR that best fits the observed PWC velocity data, called "U1501_Preliminary_Model" (Figure F63). This model was calculated using data for the 0-450 m interval only, where PWC data are available. For the 450-608 m interval, the highly scattered PWC data do not provide reliable constraints on the TDR models.

At least three depth intervals at Site U1501 are associated with major changes in velocity and/or density and are assigned as reference points for correlation with the seismic reflection profile. The three depth intervals of the most prominent changes are at $\sim 303 \mathrm{~m}$ (RP1), 450 m (RP2), and $600 \mathrm{~m}$ (RP3). RP1 and RP3 also correlate with the seismic sequence T60 boundary and with the seismic Tg reflector, respectively. These reference points are readily recognized in the drill core, lending further support to our models. With the additional constraints from these reference points and fitting the TDR using a polynomial function with depth, we constructed a new TDR model for Site U1501 called “U1501_modified_model” (Figure 
Figure F62. Comparison of a subset of physical properties with seismic waveform (converted to depth scale using best-fitting TDR model) and seismic image (in timescale).

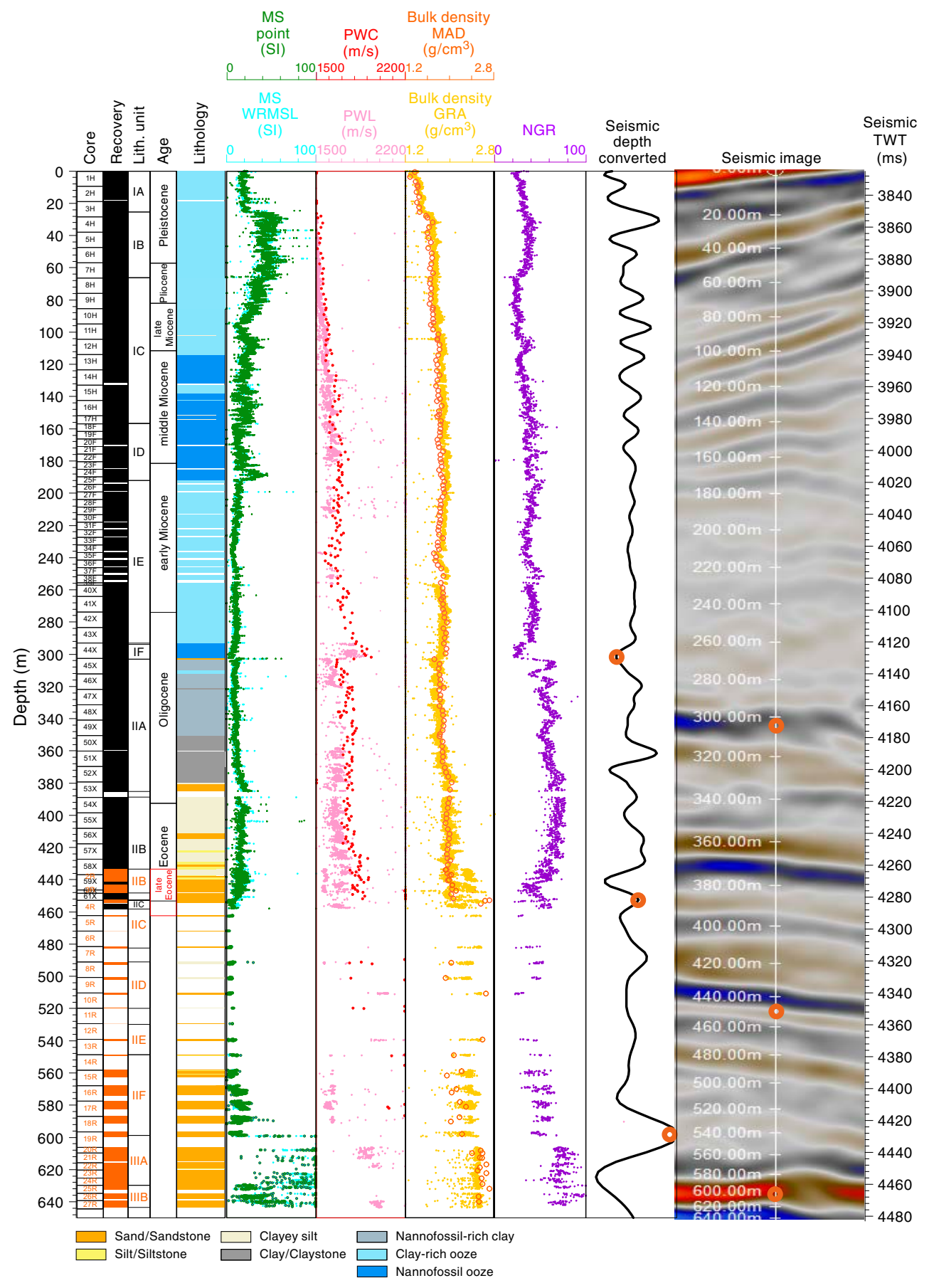

F63). The modified TDR model with constraints of the three reference points is, in general, in line with the preliminary TDR model.

We also compared our TDR models of Site U1501 with those of Sites 1148 (Shipboard Scientific Party, 2000), U1431 (Li et al., 2015b), U1499, and U1500 (see the Site U1499 and Site U1500 chapters [Sun et al., 2018b; Stock et al., 2018]). Our calculated TDR models for Site U1501 show substantial agreement with the TDR models of most of these drill sites, especially with the model of Site 1148 (Figure F64).
Using the best-fitting TDR model (U1501_modified_model), we were able to convert depth scale to timescale for all core measurements. Such conversion enabled us to display the core measurements directly on top of the time-based seismic sections, facilitating identification of correlated features, as illustrated in the example in Figure F65. 
Figure F63. TDR curves, Site U1501. U1501_preliminary_model was primarily based on PWC velocity data for depths shallower than $\sim 450 \mathrm{~m}$, an interval where PWC data are available. U1501_modified_model was based on the preliminary model with additional constraints from three reference points (RP1-RP3).

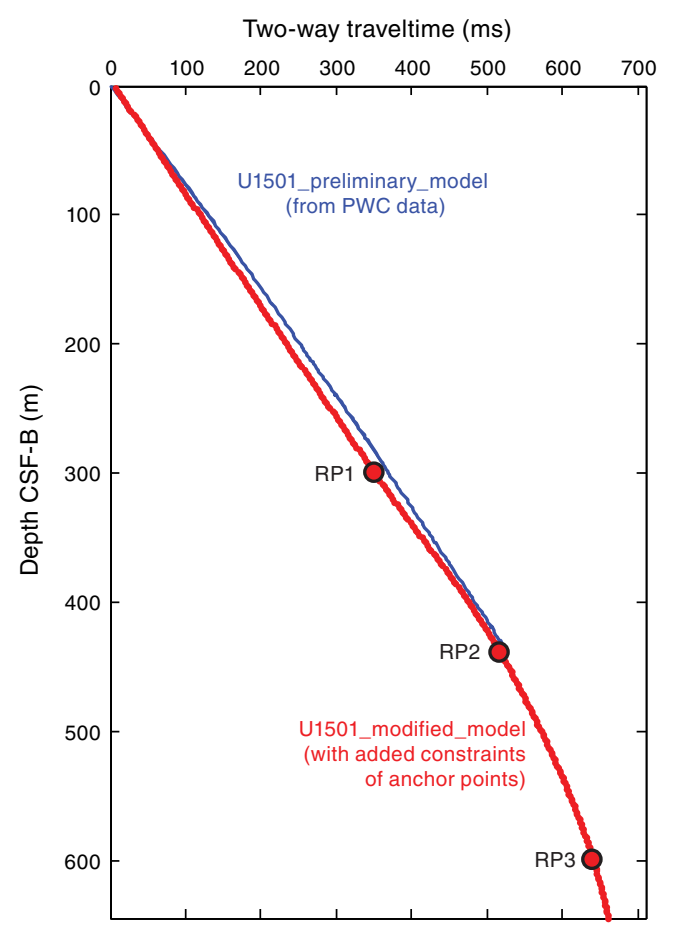

\section{Synthetic seismograms}

To further illustrate the relationship between the core measurements at Site U1501 and the seismic reflection profile, the Seismic interpretation module in Petrel was used to compute synthetic seismograms based on the relevant core measurements. Synthetic traces were generated by convolving the reflectivity from the density of core samples and the smoothed velocities from the PWC together with the source wavelet that best fits the seismic data (Ricker 2_30 Hz; Figure F66).

Seismic impedance $(\mathrm{SI})$ of a rock layer is the product of its average seismic velocity $\left(V_{\mathrm{P}}\right)$ and density $(\rho)$ (i.e., $\left.\mathrm{SI}=V_{\mathrm{P}} \times \rho\right)$. The seis-
Figure F64. Site U1501 TDR curves, including U1501_preliminary_model and U1501_modified_model, compared to TDRs for Sites U1499, U1500, and 1148 (Li et al., 2008).

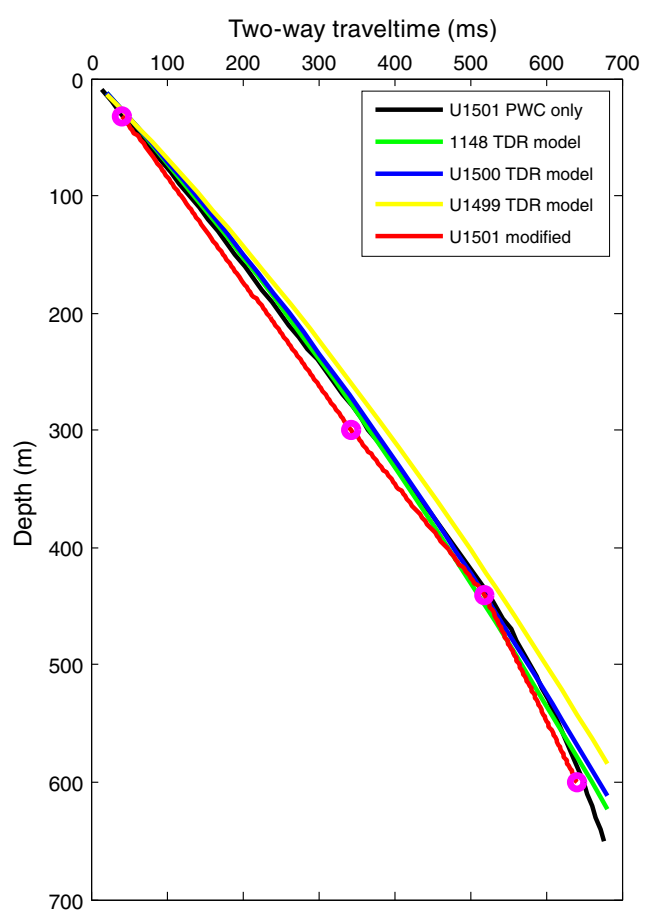

mic reflection coefficient (RC), in turns, measures the change in the seismic impedance between two adjacent rock layers. Thus, we can expect greater amplitudes in the modeled seismogram for rock layers with larger $\mathrm{RC}$ values. The resulting synthetic seismogram shows strong reflectors at several depth intervals, including $\sim 303$ and $600 \mathrm{~m}$, that are consistent with the observed seismic unconformities. The transition between lithostratigraphic Units II and III at $600 \mathrm{~m}$, for instance, is marked by a sharp increase in density and velocity; the net result is a strong positive increase in impedance (Figure F66). 
Figure F65. Seismic section at Site U1501 with thin strip of synthetic seismogram and lithostratigraphic units overlain at drill hole location. Also shown are selected core and downhole logging measurements converted to depth scale using best-fitting TDR model, including magnetic susceptibility (core), thorium (logging), uranium (logging), PWL (core), density (core and logging), and NGR (core and logging).

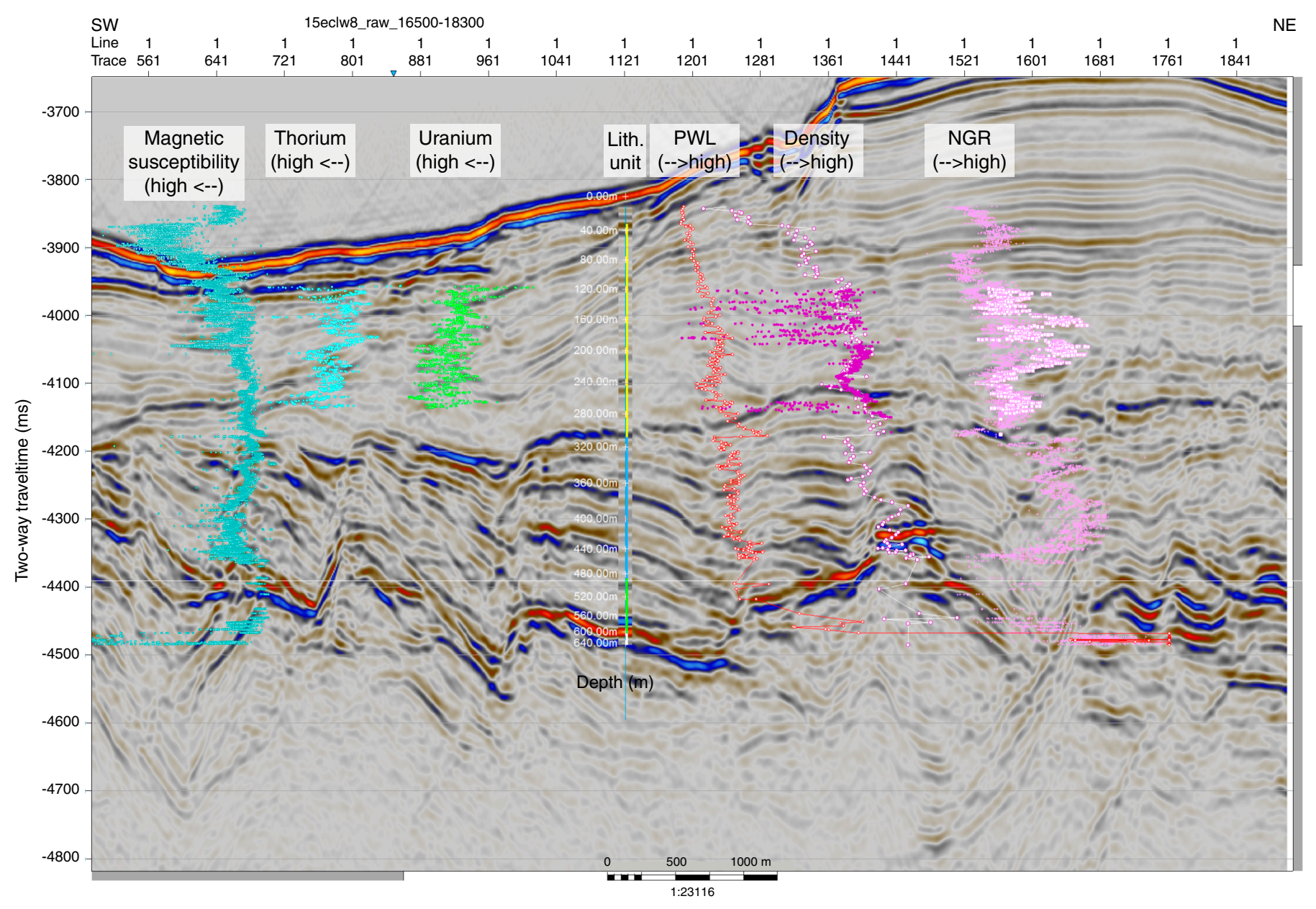




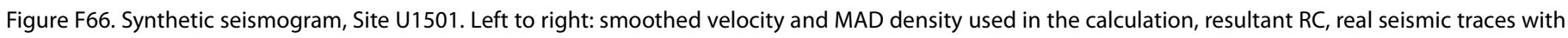
synthetic seismogram inserted in the center, and seismic source function "Ricker 2_30 Hz" used in modeling. TVD = true vertical depth from Petrel software.

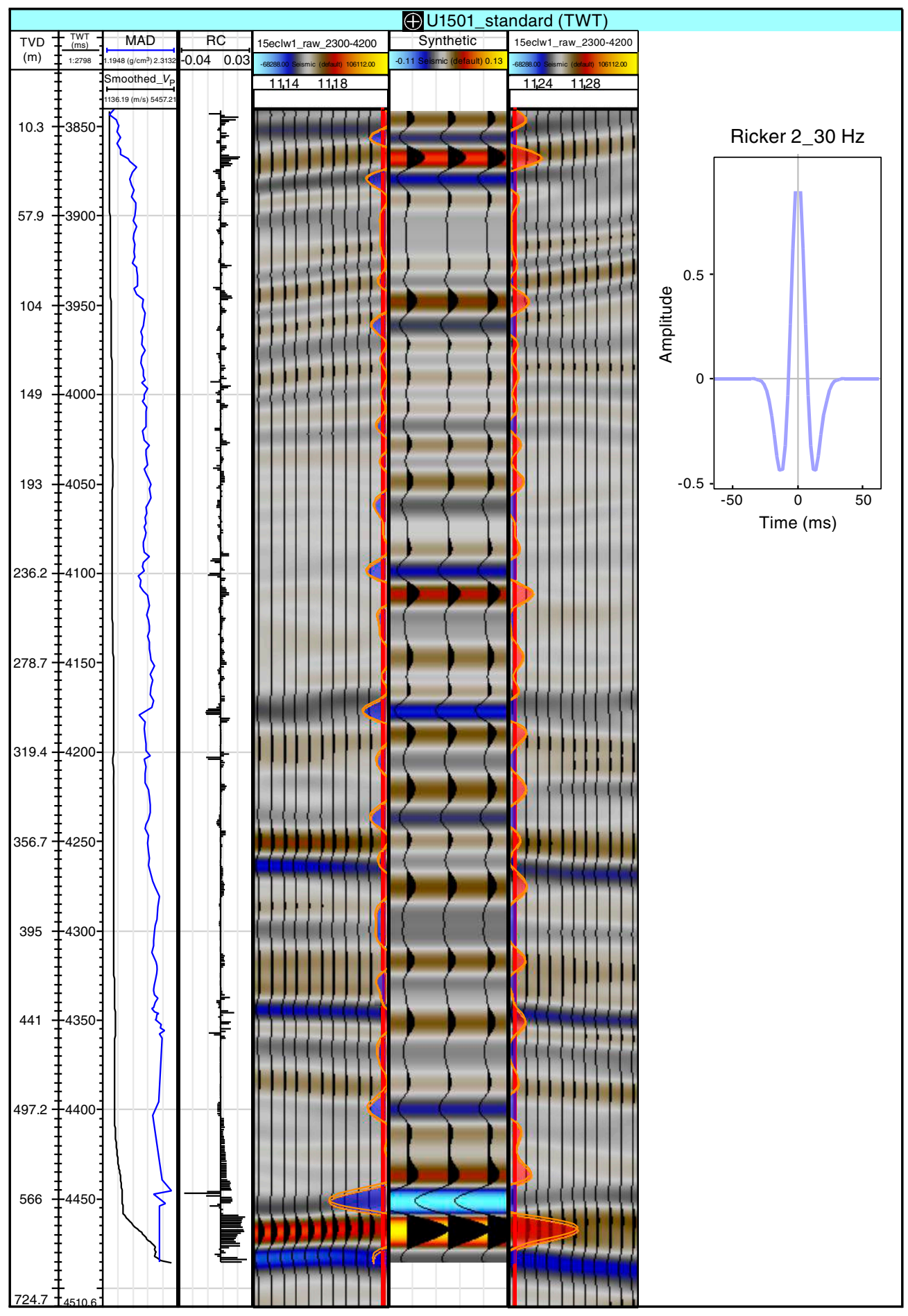




\section{References}

Alabi, O.O., Edilbi, A.N.F., Brolly, C., Muirhead, D., Parnell, J., Stacey, R., and Bowden, S.A., 2015. Asphaltene detection using surface enhanced Raman scattering (SERS). Chemical Communications, 51(33):7152-7155. http://pubs.rsc.org/en/content/articlehtml/2015/cc/c5cc00676g

Barnes, R.O., and Goldberg, E.D., 1976. Methane production and consumption in anoxic marine sediments. Geology, 4(5):297-300. https://doi.org/10.1130/0091-7613(1976)4<297:MPACIA >2.0.CO;2

Berner, R.A., and Raiswell, R., 1984. C/S method for distinguishing freshwater from marine sedimentary rocks. Geology, 12(6):365-368.

https://doi.org/10.1130/0091-7613(1984)12<365:CMFDFF >2.0.CO;2

Briais, A., Patriat, P., and Tapponnier, P., 1993. Updated interpretation of magnetic anomalies and seafloor spreading stages in the South China Sea: implications for the Tertiary tectonics of Southeast Asia. Journal of Geophysical Research: Solid Earth, 98(B4):6299-6328. https://doi.org/10.1029/92JB02280

Clift, P.D., Wan, S., and Blusztain, J., 2014. Reconstructing chemical weathering, physical erosion and monsoon intensity since $25 \mathrm{Ma}$ in the northern South China Sea: a review of competing proxies. Earth-Science Reviews, 130:86-102. https://doi.org/10.1016/j.earscirev.2014.01.002

Dai, Y., Yu, Q., Li, H., Wang, Z., Bai, J., and Peng, H., 2015. Threshold conditions and reservoir-controlling characteristics of source kitchen in Zhu I depression, Pearl River Mouth Basin. Acta Petrolei Sinica, 36(S2):145155. (in Chinese with English abstract) https://doi.org/10.7623/syxb2015S2013

De Vleeschouwer, D., Dunlea, A.G., Auer, G., Anderson, C.H., Brumsack, H., de Loach, A., Gurnis, M., et al., 2017. Quantifying K, U, and Th contents of marine sediments using shipboard natural gamma radiation spectra measured on DV JOIDES Resolution. Geochemistry, Geophysics, Geosystems, 18(3):1053-1064. https://doi.org/10.1002/2016GC006715

Demaison, G.J., and Moore, G.T., 1980. Anoxic environments and oil source bed genesis. AAPG Bulletin, 64:1179-1209.

Drzewiecki, P.A., and Simó, J.A., 2002. Depositional processes, triggering mechanisms and sediment composition of carbonate gravity flow deposits: examples from the Late Cretaceous of the south-central Pyrenees, Spain. Sedimentary Geology, 146(1-2):155-189. https://doi.org/10.1016/S0037-0738(01)00171-3

Exon, N.F., Kennett, J.P., Malone, M.J., Brinkhuis, H., Chaproniere, G., Ennyo, A., Fothergill, P., et al., 2002. Drilling reveals climatic consequences of Tasmanian Gateway opening. Eos, Transactions of the American Geophysical Union, 83(23):253-259. https://doi.org/10.1029/2002EO000176

Hanai, T., 1957. Studies on the Ostracoda from Japan: 3. Subfamilies Cytherurinae G.W. Müller (emend. G.O. Sars, 1925) and Cytheropterinae n. subfam. Journal of the Faculty of Science, University of Tokyo, Section 2, 11:11-36.

Harris, L.C., and Whiting, B.M., 2000. Sequence-stratigraphic significance of Miocene to Pliocene glauconite-rich layers, on- and offshore of the US Mid-Atlantic margin. Sedimentary Geology, 134(1-2):129-147. https://doi.org/10.1016/S0037-0738(00)00017-8

Hedges, J.I., Clark, W.A., and Come, G.L., 1988. Organic matter sources to the water column and surficial sediments of a marine bay. Limnology and Oceanography, 33(5):1116-1136. https://doi.org/10.4319/lo.1988.33.5.1116

Horng, C.-S., Torii, M., Shea, K.-S., and Kao, S.-J., 1998. Inconsistent magnetic polarities between greigite- and pyrrhotite/magnetite-bearing marine sediments from the Tsailiao-chi section, southwestern Taiwan. Earth and Planetary Science Letters, 164(3-4):467-481. https://doi.org/10.1016/S0012-821X(98)00239-8

Hyndman, R.D., Erickson, A.J., and Von Herzen, R.P., 1974. Geothermal measurements on DSDP Leg 26. In Davies, T.A., Luyendyk, B.P., et al., Initial Reports of the Deep Sea Drilling Project, 26: Washington, DC (U.S. Govt. Printing Office), 451-463. https://doi.org/10.2973/dsdp.proc.26.113.1974

Kirschvink, J.L., 1980. The least-squares line and plane and the analysis of palaeomagnetic data. Geophysical Journal of the Royal Astronomical Soci- ety, 62(3):699-718.

https://doi.org/10.1111/j.1365-246X.1980.tb02601.x

Krs, M., Novák, F., Krsová, M., Pruner, P., Kouklíková, L., and Jansa, J., 1992. Magnetic properties and metastability of greigite-smythite mineralization in brown-coal basins of the Krušné hory Piedmont, Bohemia. Physics of the Earth and Planetary Interiors, 70(3-4):273-287.

https://doi.org/10.1016/0031-9201(92)90194-Z

Li, C.-F., Li, J., Ding, W., Franke, D., Yao, Y., Shi, H., Pang, X., et al., 2015a. Seismic stratigraphy of the central South China Sea basin and implications for neotectonics. Journal of Geophysical Research: Solid Earth, 120(3):13771399. https://doi.org/10.1002/2014JB011686

Li, C.-F., Lin, J., Kulhanek, D.K., Williams, T., Bao, R., Briais, A., Brown, E.A., Chen, Y., Clift, P.D., Colwell, F.S., Dadd, K.A., Ding, W., HernándezAlmeida, I., Huang, X.-L., Hyun, S., Jiang, T., Koppers, A.A.P., Li, Q., Liu, C., Liu, Q., Liu, Z., Nagai, R.H., Peleo-Alampay, A., Su, X., Sun, Z., Tejada, M.L.G., Trinh, H.S., Yeh, Y.-C., Zhang, C., Zhang, F., Zhang, G.-L., and Zhao, X., 2015b. Site U1431. In Li, C.-F., Lin, J., Kulhanek, D.K., and the Expedition 349 Scientists, South China Sea Tectonics. Proceedings of the International Ocean Discovery Program, 349: College Station, TX (International Ocean Discovery Program). http://dx.doi.org/10.14379/iodp.proc.349.103.2015

Li, C.-F., Shi, X., Zhou, Z., Li, J., Geng, J., and Chen, B., 2010. Depths to the magnetic layer bottom in the South China Sea area and their tectonic implications. Geophysical Journal International, 182(3):1229-1247. https://doi.org/10.1111/j.1365-246X.2010.04702.x

Li, C.-F., Zhou, Z., Li, J., Chen, B., and Geng, J., 2008. Magnetic zoning and seismic structure of the South China Sea ocean basin. Marine Geophysical Research, 29(4):223-238. https://doi.org/10.1007/s11001-0089059-4

Li, Q., Zheng, H., Zhong, G., and Wang, P., 2005. Tectonic events indicated by late Oligocene slumped deposits from the South China Sea. Earth Science-Journal of China University of Geosciences, 30:19-24. http://en.cnki.com.cn/Article_en/CJFDTOTALDQKX200501001.htm

Li, Y.-P., and Jiang, S.Y., 2010. Boron concentration and isotopic constraints on processes affecting the chemistry of interstitial water in normal- and over-pressured basins, Gulf of Mexico. Marine Geology, 275(1-4):230243. https://doi.org/10.1016/j.margeo.2010.06.004

Liu, J., Shi, X., Liu, Q., Ge, S., Liu, Y., Yao, Z., Zhao, Q., et al., 2014. Magnetostratigraphy of a greigite-bearing core from the South Yellow Sea: implications for remagnetization and sedimentation. Journal of Geophysical Research: Solid Earth, 119(10):7425-7441. https://doi.org/10.1002/2014JB011206

Lurcock, P.C., and Wilson, G.S., 2012. PuffinPlot: a versatile, user-friendly program for paleomagnetic analysis. Geochemistry, Geophysics, Geosystems, 13(6):Q06Z45. https://doi.org/10.1029/2012GC004098

Margielewski, W., Jankowski, L., Krapiec, M., Garecka, M., Hałas, S., and Urban, J., 2017. Analysis of reworked sediments as a basis of the Palaeogene-Neogene palaeogeography reinterpretation: case study of the Roztocze region (SE Poland). Sedimentary Geology, 352:14-29. https://doi.org/10.1016/j.sedgeo.2017.02.009

McRae, S.G., 1972. Glauconite. Earth-Science Reviews, 8(4):397-440. https://doi.org/10.1016/0012-8252(72)90063-3

Nanni, U., Pubellier, M., Sang Chan, L., and Sewell, R.J., 2017. Rifting and reactivation of a Cretaceous structural belt at the northern margin of the South China Sea. Journal of Asian Earth Sciences, 136:110-123. https://doi.org/10.1016/j.jseaes.2017.01.008

Ogg, J.G., Ogg, G., and Gradstein, F.M., 2016. A Concise Geologic Time Scale 2016: Boston (Elsevier).

Pang, X., Chen, C.M., Peng, D.J., Zhu, M., Shu, Y., He, M., Shen, J., and Liu, B., 2007. Sequence stratigraphy of deep-water fan system of Pearl River, South China Sea. Earth Science Frontiers, 14(1):220-229. (in Chinese with English abstract) https://doi.org/10.1016/S1872-5791(07)60010-4

Pasteris, J.D., and Wopenka, B., 2003. Necessary, but not sufficient: Raman identification of disordered carbon as a signature of ancient life. Astrobiology, 3(4):727-738. https://www.ncbi.nlm.nih.gov/pubmed/14987478 
Pribnow, D., Kinoshita, M., and Stein, C., 2000. Thermal Data Collection and Heat Flow Recalculations for Ocean Drilling Program Legs 101-180: Hanover, Germany (Institute for Joint Geoscientific Research, Institut für Geowissenschaftliche Gemeinschaftsaufgaben [GGA]). http://www-odp.tamu.edu/publications/heatflow/ODPReprt.pdf

Roberts, A.P., 1995. Magnetic properties of sedimentary greigite $\left(\mathrm{Fe}_{3} \mathrm{~S}_{4}\right)$. Earth and Planetary Science Letters, 134(3-4):227-236. https://doi.org/10.1016/0012-821X(95)00131-U

Roberts, A.P., Chang, L., Rowan, C.J., Horng, C.-S., and Florindo, F., 2011. Magnetic properties of sedimentary greigite $\left(\mathrm{Fe}_{3} \mathrm{~S}_{4}\right)$ : an update. Reviews of Geophysics, 49(1):RG1002. https://doi.org/10.1029/2010RG000336

Russell, W.L., 1944. The total gamma ray activity of sedimentary rocks as indicated by Geiger counter determinations. Geophysics, 9(2):180-216. https://doi.org/10.1190/1.1445076

Shao, L., Cao, L., Pang, X., Jiang, T., Qiao, P., and Zhao, M., 2016. Detrital zircon provenance of the Paleogene syn-rift sediments in the northern South China Sea. Geochemistry, Geophysics, Geosystems, 17(2):255-269. https://doi.org/10.1002/2015GC006113

Shi, H., He, M., and Zhang, L., 2014. Hydrocarbon geology, accumulation pattern and the next exploration strategy in the eastern Pearl River Mouth basin. China Offshore Oil and Gas, 26(3):11-22. (in Chinese with English abstracts)

Shipboard Scientific Party, 2000. Site 1148. In Wang, P., Prell, W.L., Blum, P., et al., Proceedings of the Ocean Drilling Program, Initial Reports, 184: College Station, TX (Ocean Drilling Program), 1-122. https://doi.org/10.2973/odp.proc.ir.184.109.2000

Snowball, I.F., 1991. Magnetic hysteresis properties of greigite $\left(\mathrm{Fe}_{3} \mathrm{~S}_{4}\right)$ and a new occurrence in Holocene sediments from Swedish Lappland. Physics of the Earth and Planetary Interiors, 68(1-2):32-40. https://doi.org/10.1016/0031-9201(91)90004-2

Stock, J.M., Sun, Z., Klaus, A., Larsen, H.C., Jian, Z., Alvarez Zarikian, C.A., Boaga, J., Bowden, S.A., Briais, A., Chen, Y., Cukur, D., Dadd, K.A., Ding, W., Dorais, M.J., Ferré, E.C., Ferreira, F., Furusawa, A., Gewecke, A.J., Hinojosa, J.L., Höfig, T.W., Hsiung, K.-H., Huang, B., Huang, E., Huang, X.-L., Jiang, S., Jin, H., Johnson, B.G., Kurzawski, R.M., Lei, C., Li, B., Li, L., Li, Y., Lin, J., Liu, C., Liu, Z., Luna, A., Lupi, C., McCarthy, A.J., Mohn, G., Ningthoujam, L.S., Nirrengarten, M., Osono, N., Peate, D.W., Persaud, P., Qui, N., Robinson, C.M., Satolli, S., Sauermilch, I., Schindlbeck, J.C., Skinner, S.M., Straub, S.M., Su, X., Tian, L., van der Zwan, F.M., Wan, S., Wu, H., Xiang, R., Yadav, R., Yi, L., Zhang, C., Zhang, J., Zhang, Y., Zhao, N., Zhong, G., and Zhong, L., 2018. Site U1500. In Sun, Z., Jian, Z. Stock, J.M., Larsen, H.C., Klaus, A., Alvarez Zarikian, C.A., and the Expedition 367/368 Scientists, 2018. South China Sea Rifted Margin. Proceedings of the International Ocean Discovery Program, 367/368: College Station, TX (International Ocean Discovery Program). https://doi.org/10.14379/iodp.proc.367368.104.2018

Sun, Z., Jian, Z., Stock, J.M., Larsen, H.C., Klaus, A., Alvarez Zarikian, C.A., Boaga, J., Bowden, S.A., Briais, A., Chen, Y., Cukur, D., Dadd, K.A., Ding, W., Dorais, M.J., Ferré, E.C., Ferreira, F., Furusawa, A., Gewecke, A.J., Hinojosa, J.L., Höfig, T.W., Hsiung, K.-H., Huang, B., Huang, E., Huang, X.-L., Jiang, S., Jin, H., Johnson, B.G., Kurzawski, R.M., Lei, C., Li, B., Li, L., Li, Y., Lin, J., Liu, C., Liu, C., Liu, Z., Luna, A., Lupi, C., McCarthy, A.J., Mohn, G., Ningthoujam, L.S., Nirrengarten, M., Osono, N., Peate, D.W., Persaud, P., Qui, N., Robinson, C.M., Satolli, S., Sauermilch, I., Schindlbeck, J.C., Skinner, S.M., Straub, S.M., Su, X., Tian, L., van der Zwan, F.M., Wan, S., Wu, H., Xiang, R., Yadav, R., Yi, L., Zhang, C., Zhang, J., Zhang, Y., Zhao, N., Zhong, G., and Zhong, L., 2018a. Expedition 367/368 methods. In Sun, Z., Jian, Z., Stock, J.M., Larsen, H.C., Klaus, A., Alvarez Zarikian, C.A., and the Expedition 367/368 Scientists, South China Sea Rifted Margin. Proceedings of the International Ocean Discovery Program,
367/368: College Station, TX (International Ocean Discovery Program). https://doi.org/10.14379/iodp.proc.367368.102.2018

Sun, Z., Stock, J.M., Klaus, A., Larsen, H.C., Jian, Z., Alvarez Zarikian, C.A., Boaga, J., Bowden, S.A., Briais, A., Chen, Y., Cukur, D., Dadd, K.A., Ding, W., Dorais, M.J., Ferré, E.C., Ferreira, F., Furusawa, A., Gewecke, A.J., Hinojosa, J.L., Höfig, T.W., Hsiung, K.-H., Huang, B., Huang, E., Huang, X.-L., Jiang, S., Jin, H., Johnson, B.G., Kurzawski, R.M., Lei, C., Li, B., Li, L., Li, Y., Lin, J., Liu, C., Liu, C., Liu, Z., Luna, A., Lupi, C., McCarthy, A.J., Mohn, G., Ningthoujam, L.S., Nirrengarten, M., Osono, N., Peate, D.W., Persaud, P., Qui, N., Robinson, C.M., Satolli, S., Sauermilch, I., Schindlbeck, J.C., Skinner, S.M., Straub, S.M., Su, X., Tian, L., van der Zwan, F.M., Wan, S., Wu, H., Xiang, R., Yadav, R., Yi, L., Zhang, C., Zhang, J., Zhang, Y., Zhao, N., Zhong, G., and Zhong, L., 2018b. Site U1499. In Sun, Z., Jian, Z., Stock, J.M., Larsen, H.C., Klaus, A., Alvarez Zarikian, C.A., and the Expedition 367/368 Scientists, South China Sea Rifted Margin. Proceedings of the International Ocean Discovery Program, 367/368: College Station, TX (International Ocean Discovery Program). https://doi.org/10.14379/iodp.proc.367368.103.2018

Suttill, H.L., 2009. Sedimentological evolution of the Emine and Kamchia Basins, eastern Bulgaria [Ph.D. thesis]. University of Edinburgh. https://www.era.lib.ed.ac.uk/handle/1842/4919

Suttner, L.J., Basu, A., and Mack, G.H., 1981. Climate and the origin of quartz arenites. Journal of Sedimentary Research, 51(4):1235-1246. https://doi.org/10.1306/212F7E73-2B24-11D7-8648000102C1865D

Tauxe, L., 2010. Essentials of Paleomagnetism: Berkeley, California (University of California Press).

Torres, M.E., Brumsack, H.-J., Bohrmann, G., and Emeis, K.C., 1996. Barite fronts in continental margin sediments: a new look at barium remobilization in the zone of sulfate reduction and formation of heavy barites in diagenetic fronts. Chemical Geology, 127(1-3):125-139. https://doi.org/10.1016/0009-2541(95)00090-9

Wigley, R., and Compton, J.S., 2007. Oligocene to Holocene glauconite-phosphorite grains from the head of the Cape Canyon on the western margin of South Africa. Deep-Sea Research Part II: Topical Studies in Oceanography, 54(11-13):1375-1395. https://doi.org/10.1016/j.dsr2.2007.04.004

Wilson, R., Monaghan, P., Bowden, S.A., Parnell, P., and Cooper, J.M., 2007. Surface-enhanced Raman signatures of pigmentation of cyanobacteria from within geological samples in a spectroscopic-microfluidic flow cell. Analytical Chemistry, 79(18):7036-7041. https://doi.org/10.1021/ac070994c

Yan, P., Zhou, D., and Liu, Z., 2001. A crustal structure profile across the northern continental margin of the South China Sea. Tectonophysics, 338(1):1-21. https://doi.org/10.1016/S0040-1951(01)00062-2

Yao, B., Zeng, W., Chen, Y., and Zhang, X., 1994. The crustal structure in the eastern part of the northern margin of the South China Sea. Acta Geophysica Sinica, 37:27-35.

Zhou, D., Ru, K., and Chen, H., 1995. Kinematics of Cenozoic extension on the South China Sea continental margin and its implications for the tectonic evolution of the region. Tectonophysics, 251(1-4):161-177. https://doi.org/10.1016/0040-1951(95)00018-6

Zhou, D., Wang, W., Wang, J., Pang, X., Cai, D., and Sun, Z., 2006. Mesozoic subduction-accretion zone in northeastern South China Sea inferred from geophysical interpretations. Science in China, Series D: Earth Sciences, 49(5):471-482. https://doi.org/10.1007/s11430-006-0471-9

Zijderveld, J.D.A., 1967. AC demagnetization of rocks: analysis of results. In Collinson, D.W., Creer, K.M., and Runcorn, S.K. (Eds.), Developments in Solid Earth Geophysics (Volume 3): Methods in Palaeomagnetism: Amsterdam (Elsevier), 254-286. https://doi.org/10.1016/B978-1-4832-2894-5.50049-5 